\title{
TITÁN-KARBID/AMORF SZÉN NANOKOMPOZIT BEVONAT ELŐÁLLÍTÁSA ÉS JELLEMZÉSE
}

Ph.D. értekezés

\section{OLÁH NIKOLETT}

Témavezető: Dr. Balázsi Katalin

Környezettudományi Doktori Iskola Vékonyréteg-fizika Laboratórium

Alkalmazott és Környezetkémiai Müszaki Fizikai és Anyagtudományi Tanszék Intézet

Természettudományi és Informatikai Energiatudományi Kutatóközpont Kar

Szegedi Tudományegyetem Magyar Tudományos Akadémia 


\section{Tartalomjegyzék}

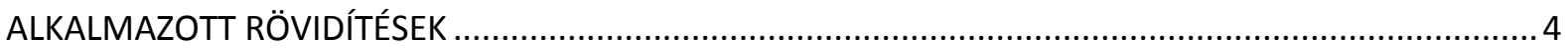

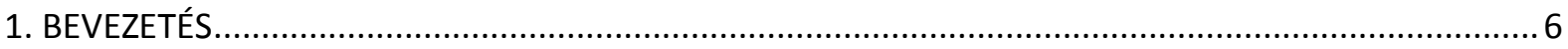

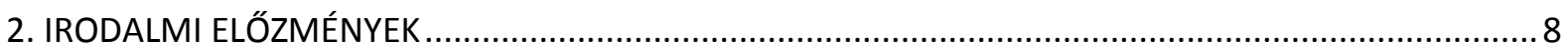

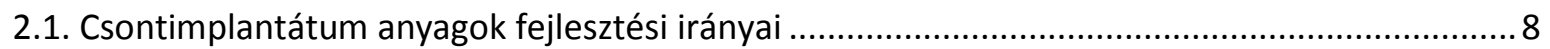

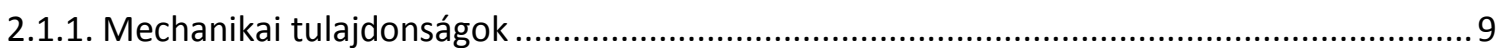

2.1.2. A TiC néhány jellemző tulajdonsága és alkalmazási területe ...........................................10

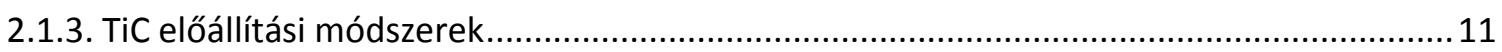

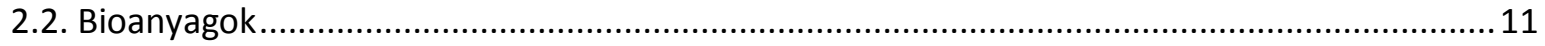

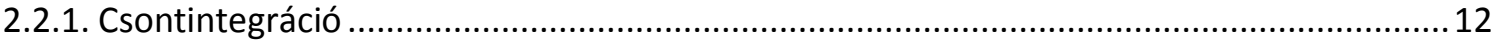

2.3. Az implantáció során fellépő korróziós problémák és lehetséges megoldásaik.........................13

2.4. Vékonyrétegek leválasztási módszerei ............................................................................... 15

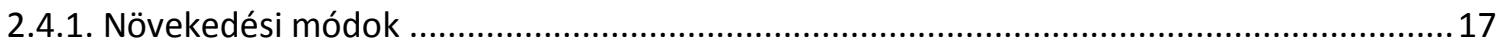

2.4.2. Szerkezeti zónadiagram, szerkezet-kialakulás kétfázisú rétegekben ................................19

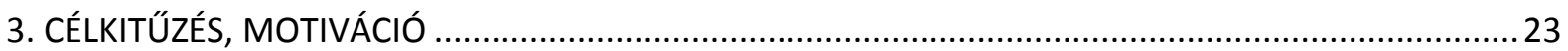

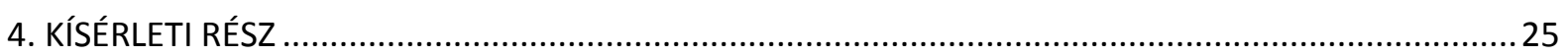

4.1. TiC/a:C nanokompozit vékonyrétegek előállítása....................................................................25

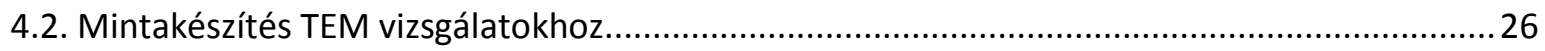

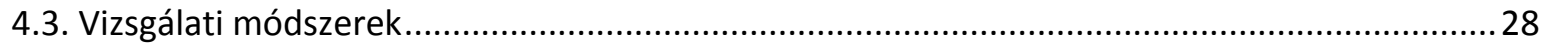

4.3.1. Transzmissziós elektronmikroszkópia (TEM) és nagyfelbontású transzmissziós

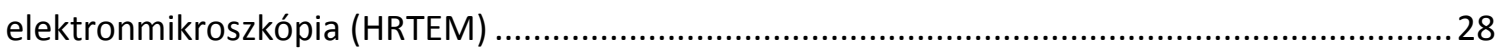

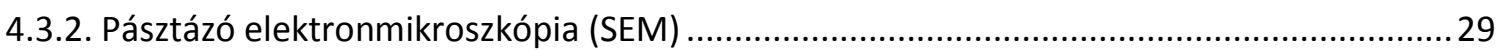

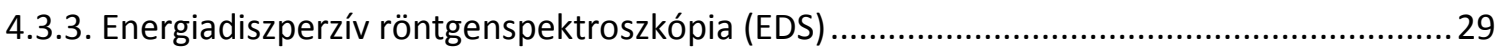

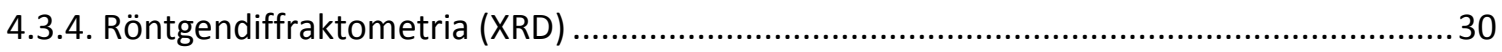

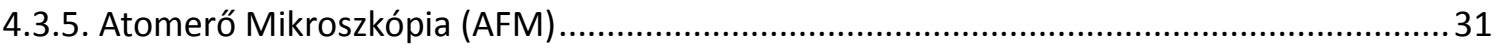

4.3.6. Raman spektroszkópia (RS) és Közeli infravörös gerjesztett Raman spektroszkópia (NIRS)

4.3.7. Fotoelektron spektroszkópiai (PES) módszerek........................................................... 32

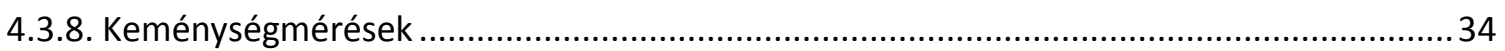

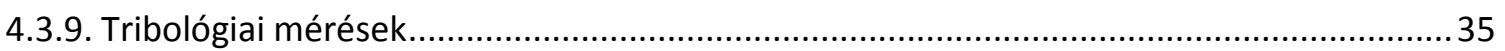

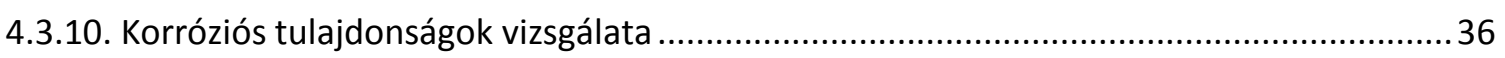

4.3.11. Induktív Csatolású Plazma Optikai Emissziós Spektrometria (ICP-OES) ………….............38

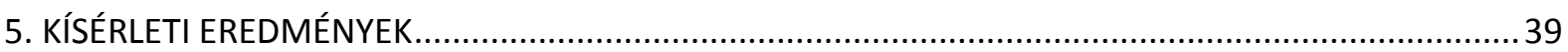




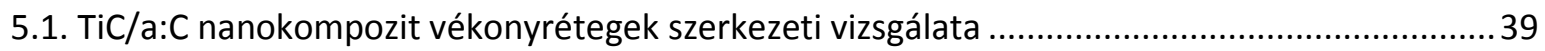

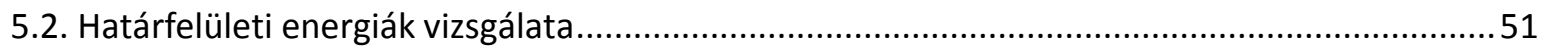

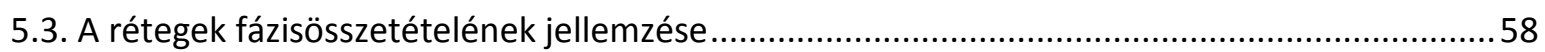

5.4. TiC/a:C nanokompozit vékonyrétegek mechanikai és tribológiai tulajdonságai .........................62

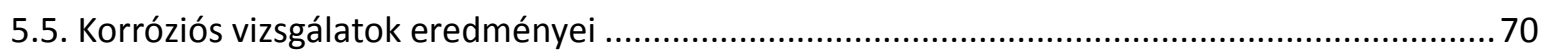

5.5.1. A minták korróziós vizsgálata 3 különböző pH értékủ oldatban......................................... 70

5.5.2. A minták korróziós vizsgálata SBF oldatban ......................................................................... 79

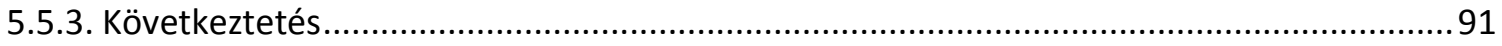

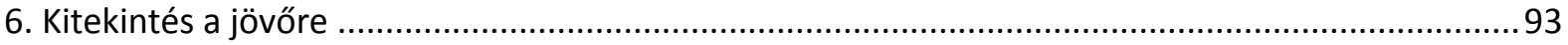

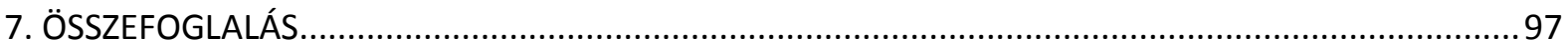

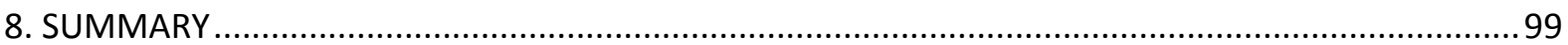

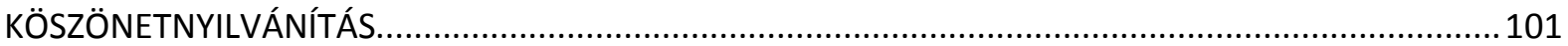

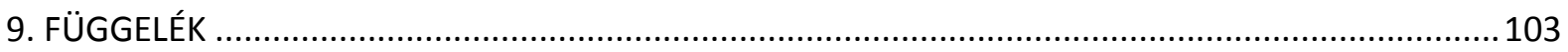

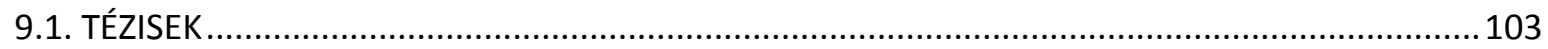

9.2. Tézisekhez szorosan kapcsolódó saját publikációk jegyzéke ................................................. 105

9.3. Egyéb, a tézisekhez nem szorosan kapcsolódó publikációim jegyzéke ....................................106

9.4. Az értekezés alapjául szolgáló konferencia részvételek (előadások, poszterek):.....................106

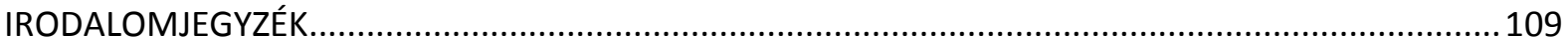




\section{ALKALMAZOTT RÖVIDÍTÉSEK}

a:C

AFM

$\mathrm{Ar}$

bcc

$\mathrm{C}$

CCD

CoCrMo

$\mathrm{CP}$

$\mathrm{CPE}$

CSM

CVD

D

DC

E

EDS

EEC

EELS

EIS

$\mathrm{E}_{\text {korr. }}$

fcc

FFT

G

$\mathrm{H}$

hcp

HRTEM

ICDD PDF

Amorf szén

Atomerő Mikroszkópia

Argon gáz

Tércentrált köbös

Szén (karbon)

Töltés Csatolt Eszköz

Kobalt-króm-molibdén ötvözet

Kereskedelmi tisztaságú

Konstans fáziselem

Folyamatos merevség mérés

Kémiai Gőzleválasztási Módszer

Rendezetlen grafit

Egyenáramú vezetés / vezetőképesség

Rugalmassági modulusz

Energiadiszperzív Röntgenspektroszkópia

Elektromos helyettesítő áramkör

Elektron Energiaveszteségi Spektroszkópia

Elektrokémiai Impedancia Spektroszkópia

Korróziós potenciál

Lapcentrált köbös

Gyors Fourier Transzformáció

Rendezett, grafitos

Keménység

Hexagonális szoros illeszkedésű

ICP-OES Induktív Csatolású Plazma Optikai Emissziós Spektrometria

$\mathrm{j}_{\text {korr. }}$

Korróziós áram

$\mathrm{j}_{\mathrm{p}} \quad$ Passzív áramsürüség

LB Langmuir-Blodgett technika

ML

Monoréteg 
NIRS Közeli infravörös gerjesztett Raman Spektroszkópia

PECVD Plazma által fokozott Kémiai Gőzfázisú Leválasztás

PES Fotoelektron Spektroszkópiai Módszerek

PLD Impulzusüzemü Lézeres Leválasztás

PVD Fizikai Gőzleválasztási Módszer

RC Soros kapcsolású áramkör

$\mathrm{R}_{\text {coat }} \quad$ Bevonat, illetve pórusok kapacitása

$\mathrm{R}_{\mathrm{cp}} \quad$ Bevonatban keletkezett korróziós termékek ellenállása

$\mathrm{R}_{\mathrm{ct}} \quad$ Töltésátviteli ellenállás érték

RF Rádiófrekvenciás energiaközlés

$\mathrm{R}_{\mathrm{p}} \quad$ Polarizációs ellenállás

$\mathrm{R}_{\mathrm{s}} \quad$ Dekompenzált oldatellenállás

RS Raman Spektroszkópia

SAED Határolt Területü Elektron Diffrakció

SBF Szimulált Testnedv Folyadék

SCE Telített kalomel elektród

SEM Pásztázó Elektronmikroszkópia

Si Szilícium

$\mathrm{SiO}_{2} \quad$ Szilícium-dioxid

TEM Transzmissziós Elektronmikroszkópia

TiC Titán-karbid

TiAl6V4 Titán-alumínium-vanádium ötvözet

UHV Ultranagy vákuum

XPS Röntgen Fotoelektron Spektroszkópia

XRD Röntgendiffraktometria

|Z $\quad$ totál impedancia érték

$\phi \quad$ Fázisszög 


\section{BEVEZETÉS}

A „nano” előtagot hivatalosan 1960-ban rendelték a Mértékegységek Nemzetközi Rendszer (SI) mértékegységeihez a $10^{-9}$ szorzófaktor kifejezésére [1]. A nanoanyagok fejlődése számos tudományterületet, többek között az anyagtudomány - és azon belül a kompozit anyagok - területét is nagyban érinti. Az anyagokkal szemben támasztott egyre növekvő igények kielégítése céljából a különféle összetevők kombinációjával olyan tulajdonságok érhetőek el, melyeket külön-külön az egyes alkotókkal makroszkópikus szinten nem lehetne megvalósítani [2]. A különböző nanorészecskéknek számos esetben az anyag tömbi formájától eltérő, sokszor valamilyen szempontból kimagasló tulajdonságai lehetnek. Ezek adagolása kompozit erősítő fázisként javíthatja az adott anyag optikai-, mechanikai-, biológiai tulajdonságait, adhéziós jellemzőit, kopás-, és korrózióállóságát. Hasonlóan a kompozit anyagokhoz a nanokompozitok esetén is az egyik alkotó folytonos mátrixként veszi körül a diszperz fázist, viszont a mátrix és az erősítő fázis közötti határfelület tipikusan egy nagyságrenddel nagyobb, mint a hagyományos kompozitoknál [2]. A nanokompozitokban minimum az egyik komponens mérete tehát legalább egy dimenzióban nanoméretű $\left(10^{-9} \mathrm{~m}\right)$ nagyságrendbe esik, mely méretcsökkenés újfajta tulajdonság kombinációkat eredményezhet [1]. A mátrix anyaga szerint megkülönböztetünk polimer-, fém-, illetve kerámia mátrix nanokompozitokat [1] [2]. Az erősítő fázis anyaga ugyanakkor állhat szemcsékből (TiC, TiN, $\mathrm{Si}_{3} \mathrm{~N}_{4}, \mathrm{SiC}$ ), lapokból (rétegszilikátok, felületi rétegek), vagy szálakból (polimer nanoszálak, szén nanocsövek).

Vékonyrétegeknek azon néhány nm-től az akár 1 - $2 \mu \mathrm{m}$ vastagságig terjedő folytonos rétegeket nevezzük, melyek a beborított felület minden pontján azonos szerkezeti és kémiai tulajdonságokkal rendelkeznek. Mind a nanokompozitok, mind a vékonyrétegek felhasználási területe szerteágazó egészen a mikroelektronikától, félvezető gyártástechnológiától az érzékelőkön, fotovoltaikus eszközökön és optikai, autóipari alkalmazásokon át a kopásálló, korrózióálló bevonatokig. Kopásálló bevonatként nemcsak vágóeszközök, szerszámok kemény bevonatára gondolhatunk, hanem humán protézisek bevonatára, mint a környezettől elhatároló, passziváló felületi rétegre is. A különböző nanokompozit vékonyrétegeket világszerte nagy erőkkel kutatják, előállításukra egyre olcsóbb, gyorsabb és egyszerűbb szintetizáló módszereket dolgoznak ki. Ezen módszerek közé tartoznak a különböző szol-gél eljárások, termikus szórás, a Langmuir-Blodgett (LB)-technika, fizikai (PVD), valamint 
kémiai (CVD) gőzleválasztási módszerek és újabban a különféle lézertechnológiai eljárások is [1].

A fémből készült orvosi implantátumok nagy részét kedvező biokompatibilitása miatt titánból vagy különböző ötvözeteiből készítik. A titánnak többek között kiváló kémiai, fizikai és mechanikai tulajdonságai vannak [3][4][5][6]. A beültetést követően azonban - korrózió vagy fémleválások miatt - titánionokat (és/vagy ötvöző elemeket) lehet kimutatni a szervezetben, melyek gyulladást okozhatnak, allergiás tünetekhez vezethetnek, s legrosszabb esetben az implantátum eltávolítása válhat szükségessé. Annak érdekében, hogy elkerüljük az ionok kioldódását, növeljük a fém korrózióállóságát, valamint biokompatibilitását, többféle módszert is lehet alkalmazni, melyek közül az egyik lehetséges a felület passziválása nanokompozit anyagokkal. Disszertációmban ilyen, TiC/a:C nanokompozit vékonyréteg passziváló, korrózióállóságot és biokompatibilitást növelő bevonat alkalmazásáról számolok be a sebészeti implantátumok élettartamának növelése érdekében, ahol az egyik alkotó (a:C mátrix) folytonos és körülveszi a diszperz fázist (TiC nanokristályok). Elöállításuk nemegyensúlyi PVD eljárással történt, $\mathrm{s}$ a kialakított szerkezet-tulajdonság kapcsolat meghatározására számos módszert felhasználtunk.

Kutatási eredményeim előzményeként a következő fejezetekben áttekintem a vékonyréteg / nanokompozit bevonatok általános irodalmát, valamint a TiC/a:C nanokompozit vékonyréteg bevonatok rétegépülési mechanizmusának az összetételre, és ezen keresztül a szerkezeti, mechanikai, adhéziós és korróziós tulajdonságokra gyakorolt hatásait, leggyakoribb előállítási módszereit. A kapott tulajdonságok ellenőrzésére szolgáló különböző szilárdtest és felületvizsgáló módszerek bemutatására is sor kerül, melyek alapján tudományos összefüggéseket és esetleges alap, mérnöki és ipari felhasználásokat is megemlítek. 


\section{IRODALMI ELŐZMÉNYEK}

A nanoszerkezetü anyagok térbeli kiterjedését tekintve, a nanoméretủ vékonyrétegek és bevonatok esetében vastagságukra jellemzö a szubmikrométeres (mikrométer alatti) tartomány [7]. A kristályos és amorf nanofázisokból álló nanokompozit bevonatok iránt egyre nagyobb érdeklődés tapasztalható az elmúlt évtizedek során, széles felhasználhatósági területeik révén [8][9][10]. Az 1990 - 2000-es évek kutatási iránya a szén nanocsövekkel módosított nanokompozitok volt. A nanocső belsejébe nyitott végükön keresztül fématomokkal ( $\mathrm{Fe}, \mathrm{Co}$ ) történő töltés, a nanocső oldalára fullerén molekulák (,nanoborsó”) -, vagy a funkciós csoporttól függően funkcionális csoportok felvitele (pl. $\mathrm{NH}_{2}$ ), a katalizátorból származó szennyeződések és a szennyvízből történő nehézfém eltávolitására is alkalmas lehet [11].

A nanokompozit rétegekre ugyanakkor bizonyos esetekben a mechanikai és tribológiai tulajdonságok szokatlan kombinációja lehet jellemező, mint például nagy keménység és szívósság, kiváló kopási és korróziós ellenállás, alacsony súrlódás, jó hővezetö és magas elektromos vezetőképesség [8][12][13][14][15]. Kiváló tulajdonságaikból következően, a nanokompozit szerkezetek alkalmazása védőanyagként vagy kemény bevonatként ígéretes lehetőségeket jelent mind az orvosi vagy alapkutatásban, mind többfunkciós, ipari és mérnöki felhasználásokban [8] [16][17][18].

\subsection{Csontimplantátum anyagok fejlesztési irányai}

A világ népességének folyamatos növekedésének és azok növekvő életkorának, az orvostudomány fejlödésének, a közlekedési balesetek gyarapodásának, a szöveti gyulladás megelőzésének köszönhetően, valamint az emberi szervezetben való hosszú életủ implantáció eléréséhez, kutatók sokasága fejleszt különböző implantátum anyagokat és védőbevonatokat világszerte [19][20][21]. Azt azonban, hogy egy adott anyag milyen mértékben felel meg, mint implantátum, nagyon sok tényező befolyásolja. Ilyen tényezők az implantátum megfelelö felületi struktúrája (csontintegráció szempontjából az érdes felület jobb), anyaga és formája, mechanikailag megfelelő stabilitása (pl. rágóerő átvitele), kopásállósága (pl. csípőprotézis esetében), minél rövidebb csontosodási ideje, biokompatibilitása, korróziómentessége, aszeptikus-, vagy atraumatikus mütéti technikája és nem utolsó sorban a csontszövethez hasonló rugalmassági együtthatója [22][23]. 


\subsubsection{Mechanikai tulajdonságok}

A nagy keménység, alacsony rugalmassági modulusz és a kis súrlódási együttható alapvető fontosságú az alap, ipari vagy orvosi alkalmazásokhoz készülő különböző bevonatok kifejlesztéséhez, mely tulajdonságok kielégítése érdekében, napjainkban széles körben elterjedt a különböző nanokompozit bevonatok használata. Bár az amorf szén, súrlódás- és kopáscsökkentő tulajdonsággal bír, ugyanakkor nem elég kemény. Különböző fém részecskék ( $\mathrm{Al}, \mathrm{Ni}, \mathrm{Nb}, \mathrm{Ta}, \mathrm{W}, \mathrm{Cr}$ és Ti) adagolásával azonban szerkezeti stabilitása, keménysége, szívóssága, rugalmas deformálhatósága nagyságrendekkel növelhető. Az amorf hidrogénezett (a:C-H) vagy hidrogénezetlen (a:C) szénmátrixba ágyazott nanokristályos titán karbid-, nitrid-, karbonitrid például egy sokoldalú anyag, amely a kemény nanokristályok és a puha amorf szénmátrix kiváló tulajdonságait ötvözi [24][25][10][26][27]. Cu és Ag részecskék adagolásával elektromos vezető és antibakteriális hatása fejleszthető. Például különböző $\mathrm{Ag}$ koncentrációkat tartalmazó $\mathrm{TiC}(\mathrm{Ag}) / \mathrm{a}: \mathrm{C}-\mathrm{H}$ nanokompozit bevonatokat ür és repülőgép alkalmazásokra készítettek magnetron porlasztással [28].

Az így kialakított, a fázisok növekedési módja szerint 2D-3D rendszerek közé sorolt, szén-fém nanokompozitokban a mátrix és a diszperz fázis között lévő határfelületnek döntő szerepe van a tulajdonságok kialakításában. Li és mtsai [29], valamint Liu és mtsai [30] az első elv sürűségfunkcionális sík hullám pszeudopotenciál számítással megvizsgálták a TiC (110) felületek szerkezeti és elektromos tulajdonságait, valamint a TiC/Ti határfelületi szerkezetét (tapadás és kötési jelleg) is. A számított eredmények a határfelületi Ti-Ti kötésre erős fémes és gyenge kovalens jelleget adtak, míg a Ti-C között erős poláris kovalens kölcsönhatást azonosítottak. A mechanikai és tribológiai tulajdonságok ugyanakkor szintén függenek a szemcse/szemcse határ mikroszerkezetétől is. A szemcseméret finomítása manipulálható a porlasztási teljesítmény által (elemösszetétel) [31], a porlasztó plazma paramétereivel (ion fluxus) [32] és a hőmérséklettel. 


\subsubsection{A TiC néhány jellemzö tulajdonsága és alkalmazási területe}

Az átmenetifémek karbidjai és nitridei tipikus fémes tulajdonságokat mutatnak elektromos, mágneses és optikai szempontból, vagyis általában csak kis mértékben térnek el az őket alkotó tiszta fém tulajdonságaitól, ugyanakkor nagymértékben befolyásolja őket a kristályszerkezetben lévő lehetséges hibahelyek száma és szerkezete. A karbidfázisokban kovalens és fémes jellegü kötések egyaránt megtalálhatóak [29] [30], de a kovalens kötés és ezáltal az atomrács-jelleg kerül előtérbe. A sürüségfunkcionál elmélet alapján végzett számításokból Li és mtsai [29] eredményeihez hasonló megállapításokra jutottak R. Ahuja és mtsai [33] is. Az említett kötési tulajdonságokból kifolyólag a TiC-nak nagyon magas, 3067 ${ }^{\circ} \mathrm{C}$ az olvadáspontja. Mindezek alapján interszticiális karbidoknak nevezzük a karbidok azon csoportját, ahol a fémrács hézagjai közé szén atomok ékelődnek és a fém és $\mathrm{C}$ között részleges elektron eltolódás játszódik le. Ez az ionos jelleg azonban csak igen kismértékü. A TiC az interszticiális karbidokon belül a tüzálló karbidok csoportjába tartozik, így kiválóan felhasználható, mint szerkezeti kerámia. Néhány alkalmazási területe, mint szerkezeti kerámia a teljesség igénye nélkül: fémfeldolgozás vágó-, és alakító szerszáma; vágólapkák, szálhúzó gyürűk, terelőgörgők, hengerek, kopó alkatrészek; szivattyútömítések, golyóálló mellények, fúvókák és elektro-kerámiaként mágnesfejek.

Mivel a Ti és C kombinációja egy viszonylag egyszerü és olcsó eljárás [34], számos nanoszerkezetü TiC bevonat modell létezik csakúgy, mint a nanoméretü többrétegü bevonatok vagy a nanoszerkezetü funkcionálisan osztályozott bevonatok [35]. A TiC fázis alkalmas a deformáció csökkentésére és növeli a bevonatok keménységét. Az ilyen típusú nanokompozitok jó keménységi értékeket mutatnak, ha a kristályméret elegendően kicsi és a puha második fázis, amely rendelkezik egy úgynevezett önkenő tulajdonsággal, segít megakadályozni a repedés terjedését [36][37][38]. A TiC kerámiákat széles körben használják az atomerőmű iparban - mint második diszperziós fázist - a mátrix belső vezetőképességének javítására, vagy a mechanikai tulajdonságok, mint például a SiC kerámiák / biokerámiák törésállóságának javítására [39][40][41]. $\mathrm{Az}^{-1} \mathrm{Al}_{2} \mathrm{O}_{3}$ kerámia mátrixba diszpergált TiC-ot mágnesfejek és vágószerszámok hordozójaként alkalmazzák és előállítását nagy energiájú golyósmalmot követően gyors-szintereléssel (SPS) valósítják meg [42]. A TiC-t továbbá széles körben használják fémmátrix kompozitok (MMC) erösítő fázisaként [43][44], valamint alkalmas jelölt lehet Ohmos érintkezőnek mikroelektronikai eszközökben, anódnak ólom-savas akkumulátorokban és szuperkondenzátorokban, vagy a platina alternatívájaként, mint katalizátor és diffúziós gát a félvezető technológiában [45]. 
Foszforsavas üzemanyagcellákban (PAFC-k), protoncserélő membrán üzemanyagcellákban (PEMFC-ek), protoncserélő membrános elektrolizátorban elektrokémiailag stabil fázisként szintén alkalmazzák [46][47].

\subsubsection{TiC elöállítási módszerek}

A felületi tulajdonságok módosítása elérhető új réteg leválasztásával, vagy a tömbi anyag felületének módosításával, illetve esetenként a kettő együttes alkalmazásával. Számos technika áll rendelkezésre TiC nanokompozitok előállítására. A vákuumban történő porlasztás például nagy rugalmasságot biztosít az anyag kémiai és szerkezeti manipulálására, különleges tulajdonságokkal rendelkező rétegeket és bevonatokat eredményezve [48], míg a TiC szelektív lézeres megolvasztása erősítő fázisként szolgálhat alumínium mátrix kompozitokban [49][50]. A porlasztás előnyeiböl kifolyólag a TiC/a:C(-H) nanokompozit vékonyrétegek előállítására legelterjedtebben használt porlasztási technikák a CVD vagy PVD eljárások és ezek különböző fajtái, mint például a nem reaktív magnetronos porlasztás [51], RF porlasztás [52][53], hibrid ionizált PVD / plazma által fokozott kémiai gőzfázisú leválasztás (PECVD) [54] és nem utolsó sorban a DC magnetronos porlasztás. Y. Wang és mtsai [55] szürt katódos vákuum ívporlasztással készítette nc-TiC/a-C:H rétegeit, El Mel és mtsai [56] egy hibrid plazma eljárás PVD-vel történő kombinálásával állította elő őket, míg H.L. Wang és mtsai [57] PECVD-t használtak TiCN rétegeik porlasztásához. DC reaktív „kiegyensúlyozatlan zárt mező” magnetronos porlasztást [58] és PLD-t [59] nc-TiC/a-C:H, valamint $\mathrm{TiC}_{\mathrm{x}} \mathrm{N}_{1-\mathrm{x}}$ rétegek szintéziséhez szintén alkalmaznak. Sedláčková és mtsai [60] Ti és C céltárgyakból szobahőmérsékleten hozták létre a TiC alapú nanokompozitokat DC magnetronos porlasztással. Bár a szakirodalomban a porlasztási hőmérséklet többnyire 200 ${ }^{\circ} \mathrm{C}$ körüli [53][61][18], a szobahőmérsékletű porlasztás előnyei a gyorsabb és költséghatékonyabb előállítás, valamint az ultranagy vákuumban $\left(10^{-8}\right.$ mbar) történő előállítás miatti tisztaság.

\subsection{Bioanyagok}

A bioanyagok a biológiai rendszerekkel való kölcsönhatás érdekében alkalmazott élettelen anyagok, mint például a fémes bioanyagok, kerámia és üveg bioanyagok, nem bontható szintetikus polimerek, biológiailag lebontható polimerek, bio-származék polimerek, 
valamint passzív és bioaktív bevonatok [62]. A bioanyagok kapcsán felmerülő legfontosabb fogalom a biokompatibilitás, mely az adott anyag azon képességét jelenti, hogy hosszú időn keresztül képes ellátni funkcióját a testben, miközben megfelelő, vagy lehetőleg semmilyen biológiai választ nem vált ki a szervezet szöveteiből [63]. Ily módon az implantátum anyagok biokompatibilitásuk alapján 3 csoportba - bioinert, bioaktív és biotoleráns - sorolhatóak [64]. Biotoleráns anyagok, mint a Co-Cr-Mo ötvözetek [65][66], müanyagok, esetén a szervezet „eltüri”, de kötőszövetes réteggel választja el azokat az élő szövetektől. A bioaktív anyagok (hidroxiapatit, trikalciumfoszfát, bioüveg) képesek beépülni a szervezetbe, vagyis fiziológiai reakcióba lépnek azzal, viszont kicsi a teherbírásuk, így inkább csontpótlásra - csontosodást elősegítendő anyag - alkalmazzák [67]. A bioinert anyagok csoportjába tartozó titán [68][69], tantál, alumínium oxid és szén alapú vegyületek igen erősek, semmilyen fiziológiai reakciót nem váltanak ki a szervezetböl, ám mechanikus rögzítésük szükséges.

A tiszta titán $882{ }^{\circ} \mathrm{C}$-on allotróp átalakuláson megy keresztül, a hexagonális szoros illeszkedésü (hcp) alfa fázis szerkezetböl a tércentrált köbös (bcc) béta fázis szerkezetbe [70]. Ennek a szerkezeti változásnak köszönhetően a titánötvözetek három osztályba sorolhatóak: $\alpha$-ötvözetek, $\alpha+\beta$-ötvözetek és $\beta$-ötvözetek. Különböző ötvözőelemek stabilizálhatják mind az $\alpha$ (például Al) mind pedig a $\beta$ fázist (például V) [70][71]. A biokompatibilitáson kívül, a bioanyagok nem lehetnek toxikusak, karcinogének, viszont kémiailag inertnek, stabilnak és mechanikailag elég erősnek kell lenniük ahhoz, hogy ellenálljanak az életük során kitett ismételt erőknek. A bioinert anyagok alkotják a fogászati implantátumok legnagyobb hányadát.

\subsubsection{Csontintegráció}

Bár az elmúlt években/évtizedekben rohamos fejlődés jellemzi az implantológia területét, napjainkban a legáltalánosabban használt fém még mindig a titán, kiváló kémiai, fizikai és mechanikai tulajdonságai miatt [22][68][72][5][73][6], és a modern implantológia fö kérdése továbbra is az implantátum és a csontszövet optimális kapcsolata [74]. A titán csontszövethez való affinitásának felfedezése, valamint a csontintegráció fogalma egészen 1977-re nyúlik vissza és Brånemark svéd professzor nevéhez füződik [75]. Az általa alkotott fogalom nem más, mint a terhelt implantátum és a csontszövet direkt, kötőszövet nélküli kapcsolata fénymikroszkópos szinten [75]. A fogalom megállapítása mellett, a hetvenes évek a csontintegrációs kutatások szempontjából egyébként is egy nagyon eredményes időszaknak 
tekinthető, hiszen ekkor fedezik fel a rozsdamentes acélt, a vitalliumot, a tantált és titánt [70], mint implantációra alkalmas anyagot [64].

\subsection{Az implantáció során fellépő korróziós problémák és lehetséges megoldásaik}

A CoCrMo és a TiAl6V4 ötvözeteket széles körben használják orvosi implantátumként. Bár ezek az ötvözetek kiváló korrózióállóságot, biokompatibilitást, nagy tartósságot és szilárdságot mutatnak [73][76][19], ugyanakkor a bőr allergiás reakcióiért legtöbb esetben az implantátum anyagokból felszabaduló fémionok okolhatóak. A szervezetbe beültetett implantátum anyagokat a biológiai rendszerek által termelt korrozív közeg veszi körül [19][77]. A TiAl6V4 ötvözetre vonatkozó kutatások korróziós problémákat mutattak [78]. A korrózió során az emberi szövetek közé elhelyezett anyag felszínéből molekulák válnak le, melyeket a szervezet antigénként kezel és különböző típusú szöveti reakciókkal válaszol. Egyrészt ezek az anyagok, ionok helyi védekezési folyamatot fagocitózist (sejtfalás) generálnak, másrészt a fémmolekulák a vér- és nyirokerek útján továbbjutva a nyirokcsomókban, lépben és a csontvelőben elraktározódnak (metallózis). A V, Al, Ti, Co, Cu, Cr, Ni vagy Mo felszabadulását a szomszédos szövetekbe több korábbi vizsgálat alapján határozták meg [79][80][81], mely ionok kijutása a felületükön spontán képződött passzív oxidréteg feloldódása útján [82] valósulhatott meg. A korrozív közegnek, valamint a passzív réteg eltünésének köszönhetően, ezek a fajta fémionok felszabadulnak a szervezetben és szöveti gyulladást okozhatnak, míg a Ti ion képes az implantátum lazításában részt vevő, a csontok bontását fokozó anyagok - pl. citokinek - felszabadítására [83][69][84].

Hsu és mtsai [85] [23] az agresszív klorid ion korróziófokozó hatását vizsgálták fém implantátum ötvözetek esetében. Hasonlóan az ő munkájukhoz, Y. Okazaki is, az oldat pH-ja mellett, a klorid $\left(\mathrm{Cl}^{-}\right)$koncentrációtól teszi függővé a fémfelszabadulás mennyiségét [86]. Munkájuk eredményeként megállapították, hogy az általuk vizsgált Ni-Ti ötvözetből felszabaduló Ni mennyisége sokkal kisebb volt, mint a Co-Cr-Mo-Ni-Fe ötvözetböl és rozsdamentes acélból felszabaduló Ni mennyisége [86]. A különböző Ph értékű oldatokba kioldódott fémek - Cr, Ni, Mo, Mn, Co, Ti, Fe - koncentrációját ppb-ben (ng / ml) határozták meg és a fémion felszabadulási sebessége valamint a $\mathrm{pH}$ értékek közötti korrelációt állapították meg [86]. Egy másik tanulmányában Y. Okazaki felismerte, hogy az áramsűrüség ingadozási tartományát a SUS316L rozsdamentes acél, Co-Cr-Mo öntvény ötvözet és a 
különféle Ti ötvözetü hordozókon képződött passzív réteg lerombolódása és kialakulása okozza [82]. Kutatásaik során több lehetséges passziváló réteget - $\mathrm{ZrO}_{2}, \mathrm{Nb}_{2} \mathrm{O}_{5}, \mathrm{Ta}_{2} \mathrm{O}_{5}$ és $\mathrm{PdO}$ - is összehasonlítottak és megállapították, hogy az anódos polarizációs tulajdonságok $\mathrm{Zr}$, $\mathrm{Nb}$, Ta és Pd hozzáadásával javulnak, ugyanis ezek erösítik a $\mathrm{TiO}_{2}$ passzív réteget, amely az új Ti ötvözeten van. Az általuk vizsgált hordozók közül, a 0,2 \% Pd-t tartalmazó Ti-15Zr4Nb-4Ta ötvözet sokkal jobb korrózióállóságot mutatott, mint a Ti-6Al-4V ELI (extraalacsony intersztitiális) ötvözet [82].

$\mathrm{Az}$ áttekintett irodalomban említett problémákra tehát többféle megoldás is lehetséges, csakúgy, mint a beültetés előtti megfelelő előkezelés, vagy a fém eszközökre felvitt védőréteg, felületi bevonat [87]. Napjainkban a biokompatibilis - Al- és V-mentes - $\beta$ típusú Ti ötvözetek egyre inkább elterjednek, mivel ezek olyan nem-toxikus elemeket tartalmaznak, mint a nióbium $(\mathrm{Nb})$, molibdén $(\mathrm{Mo})$, tantál $(\mathrm{Ta})$, mangán $(\mathrm{Mn})$ és a cirkónium (Zr), ráadásul a csonthoz hasonló Young modulusz értékkel rendelkeznek (10 - $30 \mathrm{GPa})$ [88][89][90][91]. A $\beta$-típusú Ti ötvözetek további előnye, hogy egy tömör rutil szerkezettel rendelkező különösen inert oxidréteg $\left(\mathrm{TiO}_{2}\right)$ alakul ki felszínükön $\left(-\mathrm{ZrO}_{2}, \mathrm{Nb}_{2} \mathrm{O}_{5}, \mathrm{Ta}_{2} \mathrm{O}_{5}\right.$ és PdO - [82]) [92]. Az említett elemek (Nb, Ta, stb.) alkalmazásának legfontosabb hátrányai azonban az implantátumok előállításának megemelkedett költsége és rosszabb mechanikai tulajdonságaik. Az implantátumok felületének módosítására számos egyéb módszer is alkalmazható, ideértve az ionimplantációt [93], homokszórást [94], $\mathrm{Al}_{2} \mathrm{O}_{3}$ homokszórással és savas maratással (SLA) kialakított mikro-érdes Ti felületek alkalmazását, hökezelést és lúgos kezelést (SMART), hidrogén-peroxid és hökezelést (SAOH), valamint szulfát elektrolitokban történő potenciosztatikus anodizálást állandó elektromos áramellátáson keresztül (ECH) [95]. Az implantátumok érdessége ugyanis az egyik legfontosabb tulajdonság, mivel a növekvő durvaság megnövelheti a csontintegrációt és a sejtek tapadását [69].

További lehetséges megoldás a különböző térfogati frakciójú Mg-TiC nanokompozitok szintetizálása dezintegrált olvadék-lerakódási technikával, amelyet forró extrudálás követ [96]. Wen és mtsai [97] egy egyszerü kémiai kezelést alkalmaztak, nevezetesen $140{ }^{\circ} \mathrm{C}$-os hígított lúgban végzett inkubálást, míg Hanawa [98] a titánba történő kálcium ion implantáció hatását vizsgálta. Mindkét esetben, Ca-P kicsapódást figyeltek meg a hordozókon.

Az implantátum anyag felületére felvitt minél erősebb és stabilabb védőbevonat rutil-típusú $\mathrm{TiO}_{2}$, vagy TiC/a:C vékonyréteg - is növelheti a korrózióállóságot [99]. Ezek a védőbevonatok, mint egy gát, megakadályozzák az implantátum anyagnak, az őt körülvevő korrozív közeggel való érintkezését, ezáltal csökkentve a fémionok felszabadulásának 
valószínűségét [100][101][102]. A $\mathrm{TiO}_{2}$ passzív réteg spontán is formálódik a TiAl6V4 ötvözeten és Ti hordozókon, bár ebben az esetben kémiailag nem annyira stabil, mint a mesterségesen, erre a célra megfelelő eljárással felvitt, legtöbb esetben rutil-típusú $\mathrm{TiO}_{2}$. A $\mathrm{TiO}_{2}$ réteg is, önmagában bizonyos hátrányokkal rendelkezik, mint az alacsony tribológiai tulajdonságok, kis keménység és szélsőséges körülmények között - klórozott környezet könnyen lebomlik [89][103][72]. Ezen kívül, a különböző Ti alapú implantátumokon képződő oxidok bizonyos formái, például a TiAl6V4 ötvözeten létrejövő $\mathrm{V}_{2} \mathrm{O}_{5}$, feloldódhat alacsonyabb korrózióállóságot eredményezve és szintén V iont juttatva a szervezetbe [68].

A kutatások és fejlesztések egészen a '70-es évekre nyúlnak vissza, mégis számos megoldatlan kérdés továbbra is fennáll az implantológia területén. A különböző kutatók a legkülönbözőbb anyagokkal és módszerekkel próbálják megtalálni a legjobb megoldásokat, legkiválóbb anyagokat, legoptimálisabb módszereket. A kérdéskör a mai napig nyitott, így a fent említett problémák orvosolására TiC/a:C védőrétegek fejlesztését kezdtem el szobahőmérsékletű DC magnetronos porlasztással. Az előzőekben már ismertetett előnyökböl kifolyólag a TiC/a:C egy kiváló potenciális jelölt lehet, mint a felületet passziváló, barrier védőréteg, magas mechanikai keménységének, jó tribológiai tulajdonságainak, nagyszerü korrózióállóságának, jó biokompatibilitásának és nem utolsó sorban a szélsőséges körülményekkel szembeni stabilabb ellenállásának köszönhetően [103][48][104][105][46]. Figyelembe véve az irodalmi adatokat, miszerint a felületen létrehozott érdesség növeli a korróziós ellenállást és adhéziót, valamint gyorsítja a csontsejteknek a felületre történő migrációját, rétegeimet bizonyos esetekben érdesített felületü implantátum hordozókra porlasztottam. Mivel azonban az érdes felületen a baktériumok is jobban megtapadnak, a különböző paraméterek összehasonlítására csiszolt felületü hordozókat is kipróbáltam. A DC magnetronos porlasztásra - a már említett előnyökön kívül - a következő okok miatt esett választásom: a rétegek kémiai összetétele könnyen megváltoztatható, a nagyméretű rétegek előállítása egyszerű, veszélyes gázok vagy vegyi prekurzorok nem használatosak, olcsó és egyben környezetbarát eljárás [106][107][108][109][110].

\subsection{Vékonyrétegek leválasztási módszerei}

A nanokompozit vékonyrétegek előállítására felhasználási területtől függően más-más leválasztási technológia alkalmazása szükséges. A PVD eljárások közé soroljuk a párologtatást, porlasztást, valamint az impulzusüzemü lézeres leválasztást (PLD). Mindegyik 
esetében a vékonyréteg anyagát gőz-, vagy gázfázisba visszük, melyhez energiát közlünk a rendszerrel. Az energiaközlés módja szerint, melegítés esetén párologtatásról vagy PLD-ről, ionbombázás esetén porlasztásról beszélünk.

A katódporlasztás alapja egy ritkított térben két elektróda között létrehozott önfenntartó villamos kisülés, plazma létrehozása. Ebben a ritkított térben az elektronok felgyorsulnak és ütköznek a többnyire nemesgáz-atomokkal, amelyekről további elektronokat szakítanak le. Az így keletkezett pozitív ionok az erőtér gyorsításának hatására a katódba csapódnak és amennyiben energiájuk nagyobb a kötési energiánál, atomokat löknek ki onnan. Az így kilökött atomok a katód alatt elhelyezkedő anódra kapcsolt hordozóra - rendszerint földpotenciálon van - csapódnak. A folyamat feltétele a plazma létrejötte. A vékonyréteg forrása egy ionbombázásnak kitett céltárgy (target), melyre néhány $100 \mathrm{~V}$ feszültséget kapcsolunk. Nagyjából 10 $10^{-1} 10^{-3}$ mbar nyomású argon (Ar) gázt eresztünk be a vákuumrendszerbe és a létrejövő gázkisülés ionjaival bombázzuk a céltárgyat/céltárgyakat. A katódporlasztásnak 3 különböző fajtáját szokás alkalmazni: A szigetelö anyagok porlasztását rádiófrekvenciás $(\mathrm{RF})$ energiaközléssel lehet végezni, míg a különböző nitridek $\left(\mathrm{TiN}, \mathrm{Si}_{3} \mathrm{~N}_{4}\right)$ rétegeinek előállítását argon-nitrogén gázelegy beengedésével, reaktív porlasztással tudjuk megvalósítani. Reaktív porlasztás esetén a reakciótérbe került nitrogén gáz - a nemesgáz atomjaihoz hasonlóan - ionizálódik, s az ionizált atomok a céltárgy gázfázisba hozott atomjaival, illetve azok ionjaival a hordozó felszínén különböző nitrid vegyületeket képeznek.

A harmadik és egyben legegyszerübb porlasztási megközelítés az elektromosan vezető forrásanyagot felhasználó egyenáramú (DC) magnetronos porlasztás, mellyel pl. nagy törésmutatójú, kopásálló, a hordozón jól tapadó optikai multirétegeket is megvalósíthatunk. A céltárgy mögött egy erős állandó mágnes található, melynek feladata, hogy a céltárgy környezetében megfelelő elektromos és mágneses teret hozzon létre. E két tér a kilépő elsődleges elektronokat összetett ciklusos pályára kényszeríti, így jön létre az elektronplazma. A hagyományos módokkal ellentétben, a magnetron által keltett mágneses tér megsokszorozza a céltárgyból kilökött másodlagos elektronok ionizáló ütközéseit is. A mozgási energiával rendelkező részecskék irány szerinti eloszlását a magnetron (pl. neodímium mágnesek) dőlésszögével lehet állítani. A klasszikus porlasztásoknál hatékonyabb, stabilizálja a gázkisülést, ugyanakkor kisebb plazmateljesítménnyel és alacsonyabb gáznyomással is jó hozamot biztosít nagyobb rétegépülési sebességet kialakítva. Hátránya, hogy a céltárgy eróziója sokkal inhomogénebb, mint egy egyszerü sík geometria esetében. 
A vékonyréteg-épülés során az egyik legalapvetőbb paraméter, amivel számolnunk kell, a rendszerben lévő maradék gáznyomás. A gázatomok ugyanis beleütközhetnek a lerakódó mintákba, a növekvő felületbe, vagy beépülhetnek a rétegbe, megváltoztatva annak szerkezetét. Ennek, valamint a gázatomok szennyezésének elkerülése érdekében a tiszta rétegek eléréséhez célszerü ultranagy vákuum (UHV; $\mathrm{p}>10^{-8}$ mbar) háttérnyomást alkalmazni. További, a kialakuló réteg tulajdonságait befolyásoló paraméterek a hordozó hőmérséklete, a céltárgy teljesítménysürüsége, a céltárgy és hordozó távolsága, valamint a hordozó helyzete a mintatartón. Ahhoz, hogy előre tervezhető tulajdonságú rétegeket tudjunk reprodukálható módon előállítani, a gázkinetikán és az előzőekben felsorolt paramétereken kívül, fontos még a fázisdiagramok, vagyis az adott rendszer termodinamikájának, és ezzel összefüggésben a különböző rétegnövekedési módoknak az ismerete.

\subsubsection{Növekedési módok}

A réteg növekedése mindig az energetikailag legkedvezőbb helyen megy végbe. Még a legtisztábbra polírozott felületek is mutatnak néhány atomi skálájú szerkezeti elemet, pl. hosszú teraszokat, lépcsőket vagy kisebb aglomerációkat a lépcsővonalakban, melyek egyébként jól meghatározott kristálytani vonalakban futnak végig. Ha a felületi diffúzió elég gyors, egy véletlenszerúen lerakódott adatom az energetikailag legkedvezőbb helyre fog diffundálni. Alacsony hőmérséklet esetén lassúbb diffúzió megy végbe, néhány mobilis adatom találkozhat egymással a teraszon belül és további mozdulatlan adatom klaszterek képződhetnek. Azon kívül, hogy ez a növekedés ugyanannak az anyagnak az egykristályos felületén (homoepitaxia), vagy egy eltérő anyagi összetételü réteg-hordozó között valósul meg (heteroepitaxia), két paramétert még figyelembe kell vennünk. Ezek a paraméterek a felületi energia $(\sigma)$ és a rácsparaméter, vagyis a két anyag rácsillesztése. Heteroepitaxiális kapcsolat akkor tud könnyen kialakulni két anyag között, ha a leválasztott anyagnak van olyan orientációja, melyben a rácsa jó illeszkedésben van a hordozóval. Ezek alapján Bauer [111] 1958-ban a hordozó felületen történő kristálynövekedést alaptípusokba csoportosította és megállapította, hogy a kialakuló vékonyréteg mikroszerkezetét és tulajdonságait döntően termodinamikai paraméterek határozzák meg. Jó rácsilleszkedés és különböző felületi energiák esetén két különböző növekedési mód valósul meg:

1. Frank-van der Merve növekedés, ha $\sigma_{\text {réteg }}+\sigma_{\text {hordozó/réteg }} \leq \sigma_{\text {hordozó }}$

Ezt a típust, mely félvezetőkre jellemző, a tökéletes nedvesedés és sima, rétegről rétegre való ( $2 \mathrm{D}$ réteges) felépülés jellemzi. 
2. szigetes, Volmer-Weber féle a növekedés, ha $\sigma_{\text {réteg }}+\sigma_{\text {hordozó/réteg }} \geq \sigma_{\text {hordozó }}$

Ez a típus az előző ellentéte, vagyis a kialakuló réteg nem nedvesíti a felületet. A molekulák közötti kohézió sokkal nagyobb, mint a molekulák-hordozó közötti adhézió. Ez például fémek növekedésére jellemző szigetelőkön.

3. ha rácsilleszkedés eltérés van a hordozó és a réteg között, Stranski-Krastanov növekedés valósul meg, $\sigma_{\text {réteg }}+\sigma_{\text {hordozólréteg } \approx} \sigma_{\text {hordozó }}$

Ez a típus vegyes, réteges és szigetes egyaránt és a fémek növekedésére jellemző fémeken. A rétegnövekedés első lépéseként a hordozó legalább egy monoréteggel (ML) befejeződik, majd ezen szigetek kezdenek nőni. A 2D növekedés 3D-be megy át nem teljesen tisztázott okok miatt.

Az energetikai viszonyok által meghatározott különböző növekedési módokat az $\mathbf{1}$. ábra szemlélteti. A szigetes, vagy réteges növekedési mód közül az fog kialakulni, amelyik adott helyzetben energetikailag kedvezőbb.

\begin{tabular}{|c|c|c|c|}
\hline $\begin{array}{l}\text { Fedettség } \\
\text { Mechanizmus }\end{array}$ & $\theta<1 \mathrm{ML}$ & $1<\theta<2$ & $\theta>2 M L$ \\
\hline $\begin{array}{l}\text { Volmer-Weber, } \\
\text { 3D szigetes }\end{array}$ & 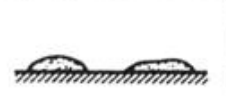 & 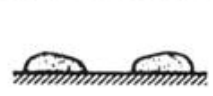 & \\
\hline $\begin{array}{l}\text { Frank-van der } \\
\text { Merwe, } \\
\text { 2D réteges }\end{array}$ & 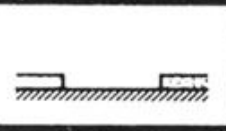 & 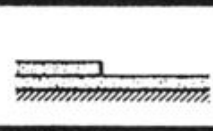 & 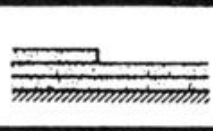 \\
\hline $\begin{array}{l}\text { Stranski- } \\
\text { Krastanov, } \\
\text { vegyes }\end{array}$ & 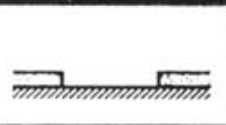 & m. & m \\
\hline
\end{tabular}

\section{1. ábra: A három különbözö heteroepitaxiális növekedési mód vázlatos ábrázolása.}

$\Theta$ a növekedö réteg vastagsága monorétegekben (ML) mérve [111].

Pashley [112] a vékonyrétegek növekedését négy főbb részre osztotta (2. ábra):

1) magképződés

2) a magok, illetve szemcsék növekedése és összenövése

3) folyamatos réteg kialakulása a szemcsék közötti csatornák feltöltődésével

4) folyamatos rétegnövekedés, mely során három mechanizmust különböztetünk meg: Ostwald-érés, zsugorodás és a szigetek migrációja 


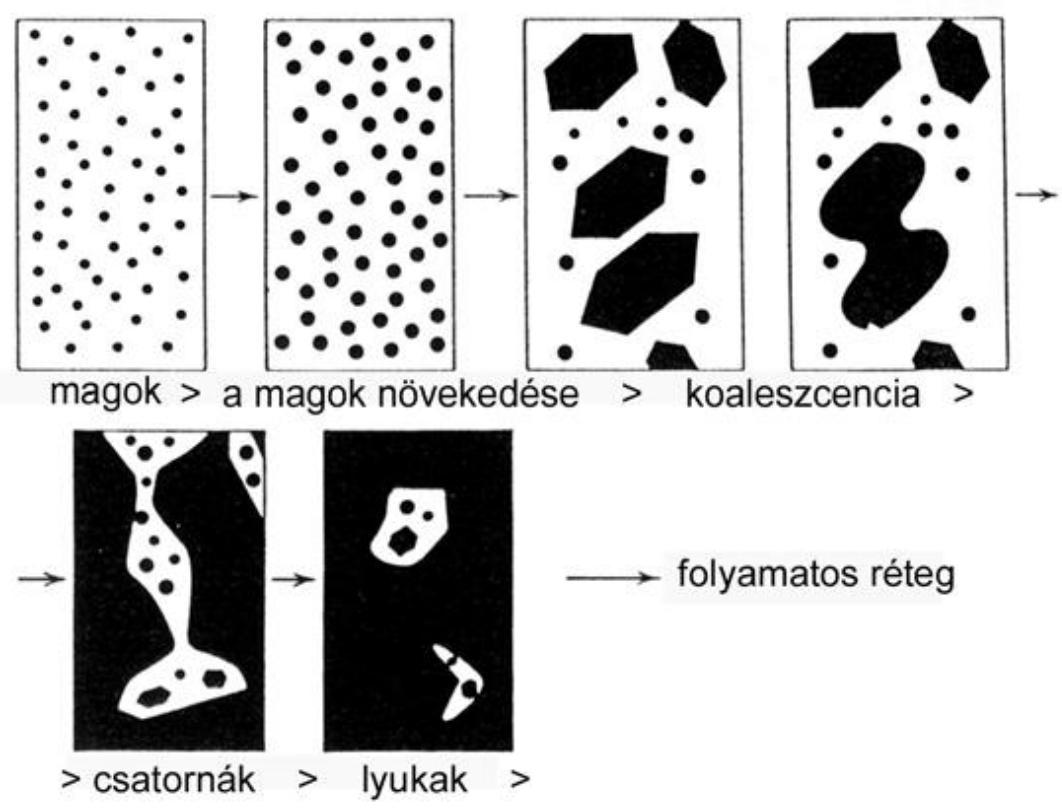

2. ábra: A vékonyréteg-kialakulási folyamatok fázisai [112].

\subsubsection{Szerkezeti zónadiagram, szerkezet-kialakulás kétfázisú rétegekben}

Kétkomponensű rendszerben az első fázis egyes kristályainak növekedése egy második fázisú - befedő, avagy szennyező - anyaggal leállítható. Ha két különböző kémiai anyag atomjai érkeznek a felszínre, a leválasztódás után egy kétdimenziós ötvözetréteg alakul ki az adszorbeált atomokból. Az így kialakult rétegszerkezeteket adott hőmérséklettartományokra (zónákra) jellemzően különböztethetjük meg.

A Barna és Adamik [37][113] által kidolgozott 2D-3D jellegű Al-O rendszerre vonatkozó kétfázisú zónadiagramot, a 3. ábra mutatja be, mely koncepcióval a Ti-C szerkezet is kiválóan jellemezhető. Amint azt a 3. ábra is szemlélteti, az Al-O szerkezetben történt morfológiai változásokat az oxigén mennyiségének függvényében vizsgálták, míg Ti$\mathrm{C}$ rendszerek esetén a $\mathrm{C}$ függvényében lehet hasonlóan jellemezni ugyanezen átalakulásokat.

Figyelembe véve a $T_{S} / T_{m}$ homológ hömérsékletet, ahol $T_{S}$ a hordozó hömérséklete és $\mathrm{T}_{\mathrm{m}}$ a réteg anyag olvadáspontja, négy különböző zónát különböztethetünk meg:

I. zóna, ahol $\mathrm{T}_{\mathrm{S}}<0,2 \mathrm{~T}_{\mathrm{m}}$ : alacsony hőmérsékleti tartomány, melyben az alap zónamodell alapján a felületi diffúziós folyamatok határozzák meg a kialakuló rétegek szerkezetét, a tömbi diffúzió nem jelentős. Az atomok felületi és térfogati diffúziója nagyon lassú, illetve szabad úthossza igen kicsi. A létrejövő magok körüli kiürített zóna szintén kicsi lesz, a magok sürün fognak elhelyezkedni és növekedésük során nem nőnek össze egymással. 
A szemcsék növekedése során nem alakul ki jelentős textúra, és amennyiben a szemcsék növekedését a szennyezők nem gátolják, a szemcsehatárok viszonylag párhuzamosan futnak egymással. Az oszlopok növekedési iránya megegyezik a porlasztó forrás irányával. Az oszlopok átmérőjét a magok kiürítési zónájának mérete határozza meg, vagyis az oszlopok általában nem egyedülálló szemcsék, sokkal inkább 1 és $10 \mathrm{~nm}$ közötti kis átmérőjủ szálakból állnak, vagy lehetnek teljesen amorfak. Amorf hordozókon a magok véletlenszerüen orientáltak. A szálak gyakran kötegekké állnak össze. Ez a szerkezet annál homogénebb, minél nagyobb a szálak átmérője, illetve minél magasabb a hőmérséklet.

Ezt követi az alap zóna-modell inhomogén T zónája, ahol az adatomok mobilitása érezhetővé válik, szabad úthosszuk megnő, s eljuthatnak a számukra energetikailag legkedvezőbb helyekre. Ez a zóna általában a 0,2 $\mathrm{T}_{\mathrm{m}}<\mathrm{T}_{\mathrm{S}}<0,4$ hőmérsékleti intervallumhoz tartozik. Az érkező adatom az alacsonyabb felületi energiájú szemcsébe fog beépülni a különböző orientációjú szomszédos szemcsék közül, ők „,nyernek” a versenyben és V alakban egyre szélesednek, miközben a kedvezőtlen felületi energiájú szemcséket kiszorítják a növekedésböl. A réteg vastagságával változik a morfológia és a versengő növekedéssel tipikusan kialakul egy textúra. Esetünkben a második magképző fázis TiC az amorf $\mathrm{C}$ mátrixba ágyazva, növekedése kinetikailag nem korlátozott. Kevesebb üreg, sűrü, apró kristályok jellemzik ezt a tartományt. A térfogati diffúzió kezd felgyorsulni. Szerkezetét tekintve polikristályos, de lehet amorf is.

A II. zóna homogén szerkezetet mutat a rétegvastagság mentén, amely a réteg aljától a tetejéig áthatoló oszlopokból áll. Az adatomok mozgékonysága és a koaleszcencia lehetősége jelentősen megnő. Ebben a zónában magas hőmérséklet uralkodik, ahol $\mathrm{T}_{\mathrm{S}}>0,4 \mathrm{~T}_{\mathrm{m}}$. A szemcsehatárok szinte merőlegesek lesznek a réteg síkjára. A keletkező magok körüli befogási zóna nagy lesz, így a rétegvastagsággal összehasonlítható szélességü oszlopok jönnek létre. A térfogati diffúzió kezd meghatározó lenni, az oszlopok közötti üregek feltöltődnek. Nagy kristályok alakulnak ki, megfelelően magas hőmérséklet esetén egykristály is létrejöhet. Az oszlopok átmérője a hőmérséklettel és a rétegvastagsággal nő.

A III. zóna szerkezetét ekviaxiális globuláris háromdimenziós szemcsék jellemzik, melyek arra utalnak, hogy a kristálynövekedést egy szennyező fázis rendszeresen blokkolta. Ez a fajta szerkezet általában szintén a magas hordozóhőmérséklet-tartománynak tulajdonítható, bár minden hömérséklet-tartományban megjelenhet különböző szemcseméretekkel, ahol szennyezőanyagok (pl. O, C) jelen vannak. Ezzel megegyezik az általunk későbbiekben bemutatott Ti-C rendszer is, ahol az első magképző fázis az amorf $\mathrm{C}$, a lehetséges fázisok közötti legalacsonyabb felületi energiájának következtében. 


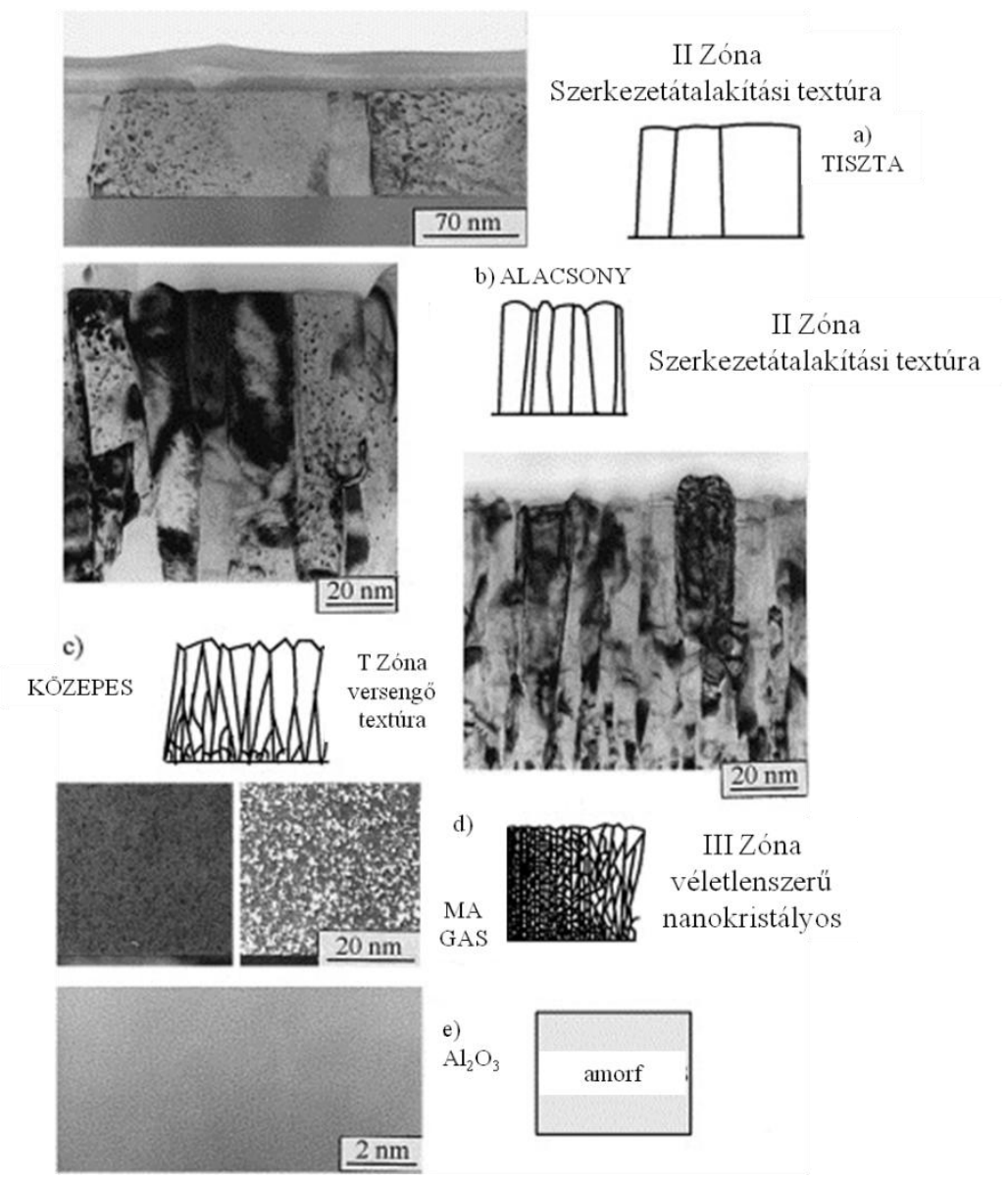

3. ábra: Termikus párologtatással szobahőmérsékleten elóállított Al vékonyrétegek szerkezeti jellemzői normál nagyvákuum feltétel mellett (a), valamint alacsony (b), közepes (c), magas (d) és nagyon magas oxigénszennyezödésnél (e) [113].

A szobahőmérsékleten porlasztott alumínium oxigén rendszer szerkezeti változásait és az orientációs körülményeket növekvő szennyeződési koncentrációval a 3. ábra mutatja be. Ez a valós szerkezetei zóna-modell megfelel az alap zóna-modell II. zónájának.

Alacsony oxigénkoncentráció esetén a koaleszcencia szakaszában a magok növekedése nem korlátozott, és a szerkezetátalakítási textúra is kialakulhat. Az orientált magok növekedése a II. zónának megfelelően oszlopos szerkezetet alakít ki (3a. ábra), habár a szennyezett szemcsehatárok mozgékonyságának csökkenése korlátozza a további magnövekedést. Az oszlopok szélessége a 3b. ábrán kisebb lesz, mint az alapmodell szerint, de a textúra még mindig a szerkezetátalakítási textúra, ám gyengébb, mint az alapmodell esetén.

$\mathrm{Az}$ első kristályok véletlenszerü orientációjának következtében közepes oxigénkoncentrációnál a magok növekedése már a koaleszcencia szakaszában korlátozott. A 
különböző Al kristályfelületeken az oxigén különböző szegregációs tulajdonságaival összefüggő növekedési verseny indul. Ez a szerkezet az alap zóna-modell T zónájának felel meg és versengő textúra alakul ki (3c. ábra).

Magas oxigénkoncentráció esetén a kristályok növekedését rendszeresen blokkolja a kristályok teljes felületét lefedö fejlődő felületi réteg. Ez azt is jelenti, hogy a magok növekedése nem akadályozhatja a szerkezetátalakítási növekedési textúra kialakulását. A réteg az alap zóna-modell III. zónájának megfelelő véletlenszerủen orientált, ekviaxiális globuláris háromdimenziós szemcsékből áll (3d. ábra). 


\section{CÉLKITÜZÉS, MOTIVÁCIÓ}

Az elmúlt évtizedekben, az MFA Vékonyréteg-fizika Laboratóriumában többféle nanokompozitból - C-Ti, C-Ni, Cu-Ag, Al / polikristályos-TiN, Al / egykristály-TiN sikeresen állítottak elő vékonyrétegeket különböző alkalmazásokra. Vizsgálták többek között a TiC, TiN, TiCN tulajdonságait és alkalmazási lehetőségeit is. Ezekhez kapcsolódva, doktori munkám során egy egyszerü és viszonylag olcsó módszer segítségével fogok előállítani TiC/a:C nanokompozit vékonyrétegeket a különböző implantátum hordozók szerkezeti és mechanikai stabilitásának növelésére, valamint a szöveti gyulladás valószínűségének csökkentésére. A szén alapú rétegek kombinálása különböző nanoméretű fém részecskékkel javíthat a tömbi anyag fizikai tulajdonságain, míg az amorf mátrixba beágyazott nanokristály méretével szabályozhatóak az anyag mechanikai tulajdonságai. Az amorf C mátrixból és TiC nanoszerkezetű kristályból álló szerkezet alkalmas a keménység növelésére. A vékonyrétegek előállítását a szóba jöhető eljárások közül a legegyszerübbnek tekinthető DC magnetronos porlasztással fogom megvalósítani. Ezzel a módszerrel kellően nagy hozam érhető el, ugyanakkor a források teljesítményének kontrolljával a réteg tulajdonságai jól szabályozhatóak, és így potenciálisan ipari körülmények közt is alkalmazható lehet.

Doktori munkám során részletesebben az alábbi pontok megvalósítását tűztem ki célul:

1. A titán tartalom hatásának vizsgálata a rétegek növekedési mechanizmusára és a TiC kristályok képződésére.

2. A rétegek mikroszerkezete és fázisösszetétele porlasztási paraméterektől való függésének tanulmányozása.

3. A rétegek összetételére ható határfelületi energiák megismerése.

4. A TiC/a:C vékonyrétegek szerkezetének mechanikai tulajdonságokra gyakorolt hatásának vizsgálata. 
5. A fém hordozókra történő porlasztás során, a szemcseszórás mellett különböző felületkezelési eljárások alkalmazása a porlasztott rétegek optimális adhéziójának érdekében.

6. A rétegek korrózióállóságának vizsgálata potenciodinamikus és EIS mérésekkel különféle elektrolitokban.

7. A bevonatok biokompatibilitásának megállapítása MG-63 humán csontsejtek 1, 3, 7 és 14 napos tenyészetével. 


\section{KÍSÉRLETI RÉSZ}

\subsection{TiC/a:C nanokompozit vékonyrétegek előállítása}

A TiC/a:C nanokompozit vékonyrétegek előállítása minden esetben a 4. ábrán látható DC magnetronos porlasztóban, szobahőmérsékleten, 2,5 x 10 $0^{-3}$ mbar argon (Ar) háttérgázban történt. A felhasznált hordozók $\mathrm{SiO}_{2} / \mathrm{Si}$, kereskedelmi tisztaságú (CP) titán (ISO5832-2), sima illetve szemcseszórt felületű TiAl6V4 ötvözet (ISO5832-3), valamint szemcseszórt felületü CoCrMo ötvözet (ISO5832-12) implantátum anyagok voltak. Az implantátum hordozókat minden esetben a Protetim Orvosi Müszergyártó Kft.-től vásároltuk. 2"-es Ti $(99,995 \%)$ és C $(99,999$ \%) Kurt \& Lesker céltárgyak egyidejü porlasztásával, a teljesítmény beállításával, az idő függvényében különböző összetételü nanokompozitokat hoztam létre. A kísérletek során a szén $(C)$ céltárgy porlasztási teljesítménye állandó $(150 \mathrm{~W})$ volt, míg a titán (Ti) céltárgy teljesítményét 5 és $150 \mathrm{~W}$ között változtattam. A porlódási sebesség, valamint a Ti és $\mathrm{C}$ sürüségének megállapítására egy $\mathrm{C} / \mathrm{Ti} / \mathrm{C} / \mathrm{Ti} / \mathrm{C} / \mathrm{Ti}$ multiréteget hoztam létre.

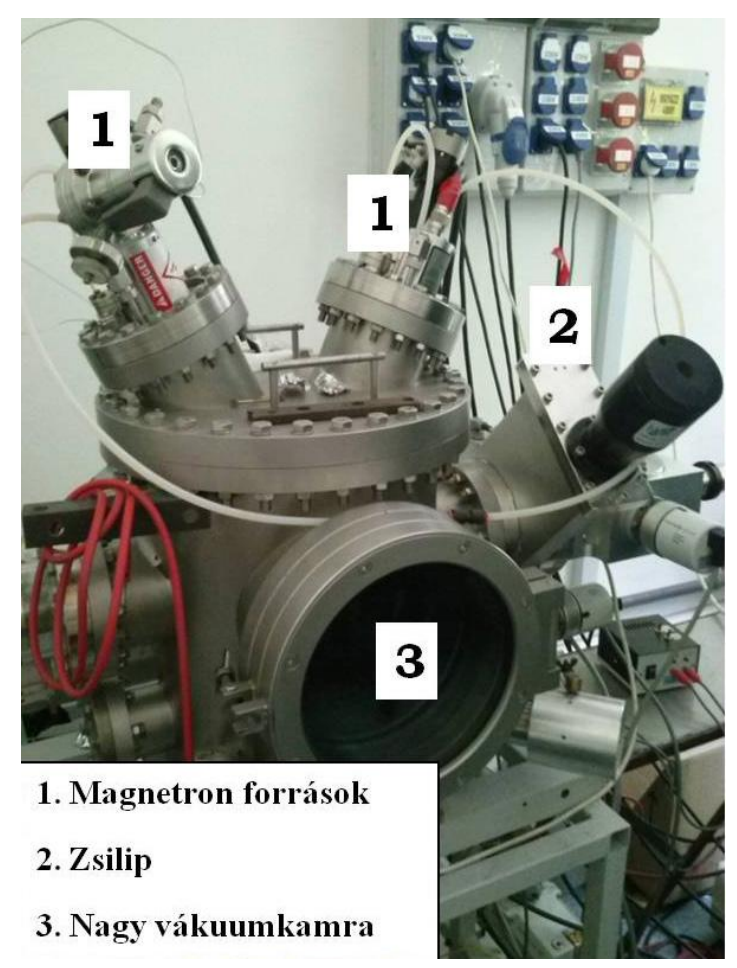

4. ábra: DC magnetronos porlasztó képe. 


\subsection{Mintakészítés TEM vizsgálatokhoz}

A TEM vizsgálatokra olyan kb. $100 \mathrm{~nm}$, míg HRTEM vizsgálatokra 10 - $50 \mathrm{~nm}$-t meg nem haladó vastagságú mintát kell készíteni, mely képes megtartani az eredeti minta szerkezeti sajátosságait, miközben a 200 - $300 \mathrm{keV}$ energiájú elektronok veszteség nélkül át tudnak rajta haladni. Erre a célra legalkalmasabb eljárás a Dr. Barna Árpádék által fejlesztett ionsugaras vékonyítás [114][115]. A vizsgálandó mintának továbbá a mikroszkóp mintatartójába is behelyezhetőnek és mechanikailag elég stabilnak kell lennie. Ezt a célt a 3 mm átmérőjü, a pereménél néhány tized mm vastag Ti gyürü szolgálja, melybe a keresztmetszeti mintákon kívül sík minták is behelyezhetőek.

A különböző hordozókra porlasztott rétegeimből keresztmetszeti mintákat készítettem úgy, hogy a két réteget a hordozójával együtt egymással szembefordítva, a már említett Ti korongba (5. ábra) szorítottam. $\mathrm{SiO}_{2} / \mathrm{Si}$ hordozó esetében hasítással, implantátum anyagok esetében pedig egy gyémántporral bevont vágókorongos fürész használatával alakítottam ki a megfelelő nagyságú hasábokat. A hasábokat tartalmazó Ti korongot ezután szénből és aralditból (CIBA-GEIGY) készített 1:4 arányú ragasztó keverék olvadékába, majd 1 órára $160{ }^{\circ} \mathrm{C}$-os kályhába helyeztem. Ezt követően a különböző szemcsenagyságú (P600, P1200, P2000) gyémántszemcsés csiszolólapon történő 3 lépéses mechanikus csiszolással 50 - 80 $\mu \mathrm{m}$-re, majd a minta közepét polírozással 20 - $30 \mu \mathrm{m}$-re vékonyítottam. Az ily módon mechanikusan elökészített mintát az ionsugaras vékonyítóba helyeztem, ahol két ionágyú 6 10 keV-os argon ionokkal, egymással ellentétes irányból, alacsony szögben $\left(1-10^{\circ}\right.$ a felülettől mérve) lőtte a forgólapra helyezett minta egyazon oldalát. A felületi topológia kialakulásának elkerülése érdekében, az első 1-másfél órában a minta teljesen körbeforgott, majd ezt követte egy $0 \div 20^{\circ}$-os, egy ágyús „lengés” (6. ábra). Ezeket a müveleteket a minta mindkét oldalán végrehajtottam, a második oldalnál egészen addig, amíg a minta - lehetőleg a két minta összeillesztési határánál - ki nem lyukadt. A minta a lyuk szélén kellően vékonnyá vált az elektronok számára, vagyis a továbbiakban TEM-mel vizsgálható. A müvelet befejezéseként, a vékonyítás során keletkezett esetleges amorfizált réteg tisztítása kis energiával, 2 keV-os Ar ionokkal történt. 


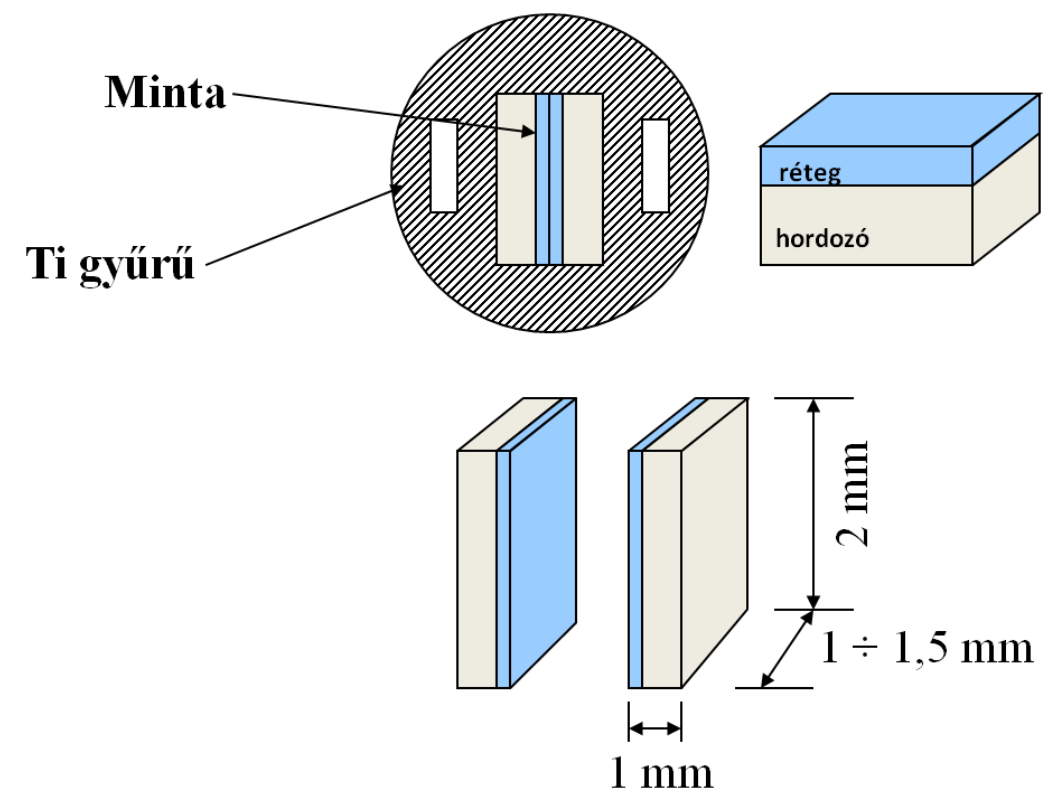

5. ábra: A TEM minta elöállításának sematikus ábrája vékonyréteg keresztmetszeti minta esetében.

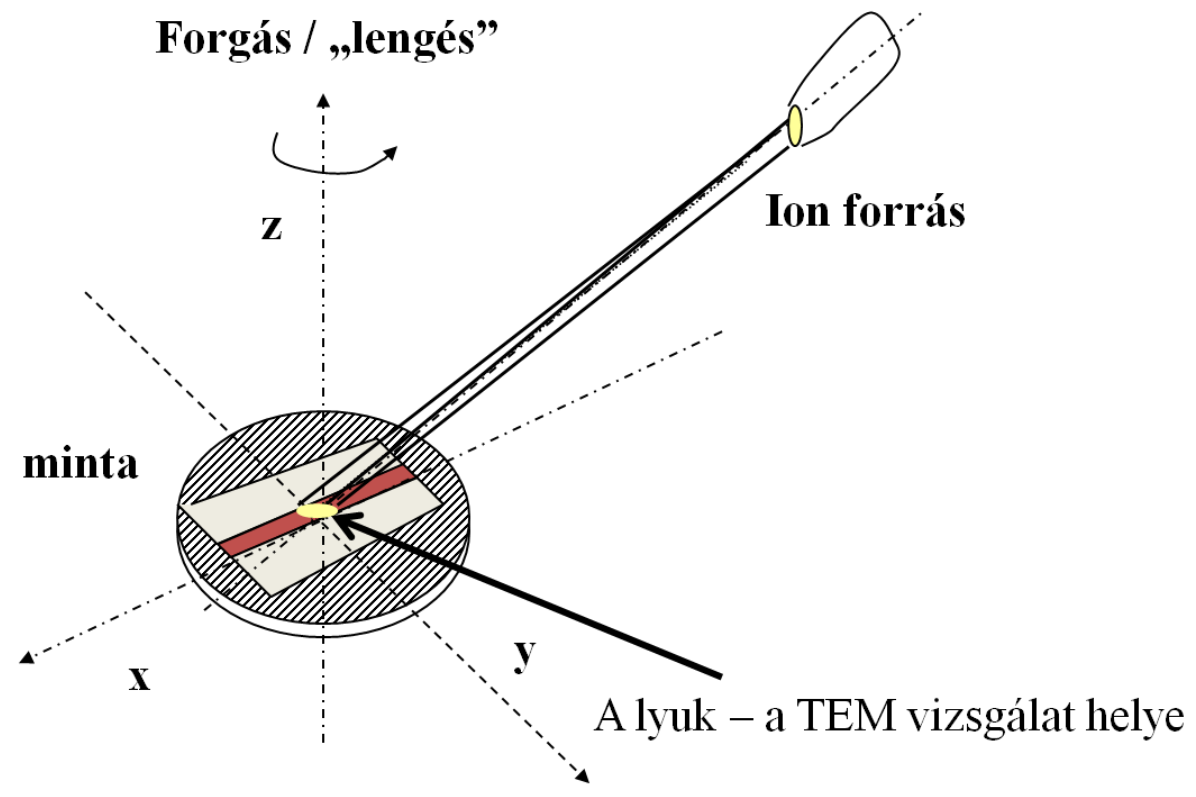

6. ábra: Ionsugaras vékonyítás mechanizmusának sematikus ábrája. 


\subsection{Vizsgálati módszerek}

\subsubsection{Transzmissziós elektronmikroszkópia (TEM) és nagyfelbontású transzmissziós elektronmikroszkópia (HRTEM)}

A transzmissziós elektronmikroszkópia (TEM) segítségével lehetőségünk nyílik az anyagok szerkezetének nanométer alatti felbontású vizsgálatára, így elengedhetetlenül szükséges a kristályos anyagok szerkezeti és kémiai jellemzésében. A TEM vizsgálatokat különféle mintákon végezhetjük; az anyagot egy ultra-vékony lemezre ( $\leq 200 \mathrm{~nm})$, ún. gridre felvitt poralakban, keresztmetszeti (XTEM), vagy sík mintaként lehet kialakítani. Sok szempontból hasonlít a fénymikroszkópiához azzal a lényeges különbséggel, hogy itt nem fotonokat detektálunk, hanem gyorsított elektronnyalábot használunk a megfigyelendő tárgy képének felnagyítására. Az elektronok fókuszálása mágneses térrel kialakított lencsékkel történik. Az elektronmikroszkópban a sugarat kondenzorlencsék fókuszálják a vizsgálandó tárgyra, amelyről az áthaladó sugarak a több lencséből álló optikai rendszerben erősen nagyított képet hoznak létre. A hagyományos TEM-mel ellentétben, a nagyfelbontású transzmissziós elektronmikroszkópnál (HRTEM) fáziskontraszton alapuló leképezést alkalmazunk. A rácsfeloldású fáziskontraszt alapja, hogy a nagyméretű objektív apertúrával több nyalábot engedünk át és ezek interferencia mintázata is megjelenik a rögzített képben. A HRTEM alkalmazásánál, az atomsíkoknak a beeső elektronsugárral párhuzamosan kell elhelyezkedniük.

A minta felnagyított képét egy fluoreszkáló ernyőn lehet megfigyelni. A modern mikroszkópok CCD (charge coupled device, vagy töltés csatolt eszköz) kamerával vannak ellátva. A kép élesre állítását az elektromágneses lencséken átfolyó áram erősségének a változtatásával lehet elérni. A TEM képalkotási folyamatában mikroszkópos és diffrakciós leképezésekről beszélhetünk. A két leképezési módot a vetítőrendszer különböző beállításaival tudjuk létrehozni. Mikroszkópos leképezésnél az objektívlencse képsíkját, míg diffrakciós módban az objektívlencse hátsó fókuszsíkját képezzük le. Határolt területü elektron diffrakcióval (SAED) ismeretlen kristályos fázisok meghatározása, illetve ismertek azonosítása is lehetséges, ugyanis a térhatároló blende használatával egy tetszőlegesen kiválasztott területről érkeznek a képernyőre az elektronok, vagyis diffrakciót csak a kiválasztott területről kapunk. 
A rétegek morfológiájának és kristályszerkezetének tanulmányozását egy $200 \mathrm{keV}$-on működő, 0,27 nm pontfelbontású Philips CM-20 és egy $300 \mathrm{keV}$-on müködő 0,17 nm pontfelbontású JEOL-3010 elektronmikroszkópokkal végeztük. Rétegeimet minden esetben keresztmetszeti mintaként állítottam elö, ahol is a minta szerkezete a minta felületére merőleges vékony metszet (interface) átvilágításával volt megjeleníthető.

\subsubsection{Pásztázó elektronmikroszkópia (SEM)}

A pásztázó elektronmikroszkópia (SEM) anyagok felületének vizsgálatára szolgáló eljárás. A SEM mérés során egy jól fókuszált elektronnyalábbal végigpásztázzuk a vákuum alatt tartott minta felületét, amelyből a minta és az elektronok közti eltérö kölcsönhatásoknak megfelelően eltérő jelek (szekunder elektronok, röntgensugárzás, stb.) lépnek ki. Míg a szekunder elektronok a minta felületéröl nyújtanak információt, a mintában gerjesztett, akár 1 - $2 \mu \mathrm{m}$ mélyről származó röntgensugarakkal az anyagi összetétel határozható meg. A mintából kilépő jeleket különböző típusú detektorokkal gyüjtjük össze. A SEM-es leképezés során a minta pontjait pásztázzuk végig az elektronsugárral, és minden egyes pontban rögzítjük a kiválasztott jel intenzitását és a megvilágítás pozícióját. A kiválasztott terület pásztázása után, vagy azzal egyidejűleg a pozíció függvényében ábrázoljuk a jel erősségét. A TEM müködésével ellentétben a minta $3 \mathrm{D}$-s felületi térképezését teszi lehetővé és nincs szükség 5 - $30 \mathrm{keV-nál} \mathrm{nagyobb} \mathrm{gyorsító} \mathrm{feszültségre.}$

A mintáinkon végzett korróziós vizsgálatok esetleges hatását az alapfémek, valamint a TiC/a:C vékonyréteggel bevont implantátum hordozók felületére LEO 1540 XB típusú pásztázó elektronmikroszkóppal végeztük 2, illetve $5 \mathrm{keV}$ gyorsító feszültséggel.

\subsubsection{Energiadiszperzív röntgenspektroszkópia (EDS)}

Az elektron-anyag kölcsönhatás egyik következménye, hogy a vizsgált anyagra jellemző röntgensugárzás jön létre. A detektorban a röntgensugárzás elektron-lyuk párokat hoz létre, melyek kialakulásához átlagosan 3,8 eV energia szükséges, így a röntgen foton energiája az elektron-lyuk párok megszámlálásával lehetséges. Az Energiadiszperzív röntgenspektroszkópia (EDS) egy olyan analitikai módszer tehát, mely a röntgen fotonok detektálásával ad információt a minta elemi összetételéről. A müszer egy olyan félvezető detektorral rendelkezik, amelyet nagy tisztaságú germánium-kristályból, vagy kevés lítiummal mesterségesen szennyezett szilícium kristályból állítanak elő. Az egyes elemek 
relatív koncentrációját a hozzájuk tartozó görbék alatti területek arányaiból számíthatjuk ki, figyelembe véve a különböző korrekciós faktorokat (rendszám, abszorpció, fluoreszcencia). Az EDS párhuzamos detektálást tesz lehetővé, relatív pontossága $3 \%$.

Kísérleteim során az energiadiszperzív röntgenspektroszkópiát használtam a rétegek elemi összetételének meghatározására. Az EDS méréseket egyrészt a fent említett SEM-be szerelt Röntec UHV-Si (Li) detektorral végeztük 3 keV-os gyorsítófeszültséggel, másrészt a Philips CM-20 elektronmikroszkóphoz szerelt NORAN típusú Ge detektorral.

\subsubsection{Röntgendiffraktometria (XRD)}

A szerkezetvizsgáló módszerek körébe tartozó röntgen diffraktometriás mérés során röntgen fotonokkal sugározzuk be a mintát. A röntgensugarak diffrakciója (elhajlása) a különböző kristályokon azok anyagi minőségére jellemző egyértelmü információt nyújt az anyag rácsszerkezetére, valamint a jellemző rácsállandókra vonatkozóan. Ezekhez a vizsgálatokhoz csak a rövid hullámhossztartományba eső sugárzást alkalmazzuk, amely hullámhossza a 100 pm-es $(0,1 \mathrm{~nm}=1 \AA$ Å) tartományba esik csakúgy, mint a legtöbb kristályos anyag rácsállandója. Ezek a nagyenergiájú röntgensugarak képesek „mélyen” behatolni az anyagba, így nemcsak a felületközeli 1 - $2 \mathrm{~nm}$-es rétegre, hanem a tömbfázisra is jellemző információt hordoznak. Alapkoncepciója, mely a 7. ábrán is látható a következő: a kristályos anyagok atomjai háromdimenziós rácsba rendeződnek. Ha erre röntgensugárzás

esik, az egyes rácspontok a rájuk eső elektromágneses sugárzást a tér minden irányába szórják. A számos atom által szórt röntgenhullámok egymással gyengítő vagy erősítő interferenciába lépnek. Ha az atomok szabályos elrendeződésűek és az ismétlődő egységek távolsága azonos nagyságrendben van a hullámhosszal, mint a kristályokban, az erősítő interferenciá(k)nak megfelelő sugárzást úgy észleljük, mintha a beeső sugár adott szöggel (v. szögekkel) való diffrakciót szenvedett volna. Ez alapján meghatározhatjuk, hogy milyen szöget kell bezárnia a kristálysíkoknak a beeső röntgensugarakkal ahhoz, hogy erősítő interferencia jöjjön létre. Ha az útkülönbség a hullámhossz egész számú többszöröse, azaz n $\lambda$, akkor a visszavert hullámok fázisban vannak, erősítő interferenciába lépnek egymással. Akkor fogunk reflexiót észlelni, amikor a $\Theta$ szög eleget tesz az $\mathbf{n} \boldsymbol{\lambda}=\mathbf{2 d} \sin \Theta$ Braggegyenletnek, mely a röntgenkrisztallográfia alapvető összefüggése. A diffraktogramokon a röntgensugarak intenzitását ábrázoljuk az ún. $2 \Theta$ szög függvényében, ahol $\Theta$ a kristálysíkok és a beesési sugár által bezárt szöge. 
Méréseinket CuKa sugárforrással és Göbel tükörrel felszerelt Bruker AXS D8 Discover típusú berendezéssel $2 \theta=10-90^{\circ}$-os szögtartományban végeztük. A szórt sugárzás detektálására GADDS 2D detektor rendszer szolgált, míg a diffraktogramok kiértékeléséhez az ICDD PDF adatbázist használtam.
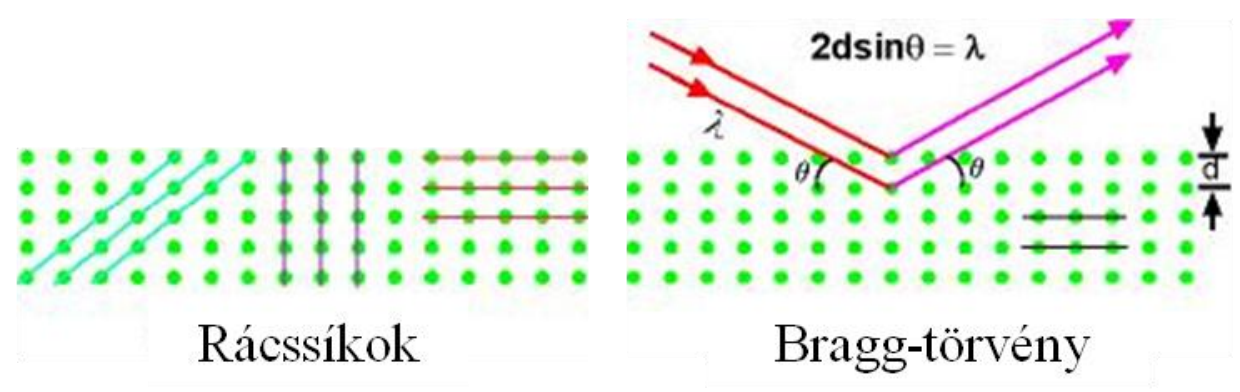

7. ábra: Röntgensugarak diffrakciója két rétegröl.

\subsubsection{Atomerö Mikroszkópia (AFM)}

Az atomerő mikroszkópia (AFM) egy, a pásztázó szondás mikroszkópok (SPM) családjába tartozó felületi képalkotó eljárás. Az AFM szondáját, mely a felület letapogatását szolgálja, egy laprugó végén található piramis alakú tü képezi. A tü egy torziós lapkán (cantilever) helyezkedik el, amely alatt a mintát piezoelektromos transzlátorokkal nagyon finoman mozgatják, így $\mathrm{x}, \mathrm{y}$, és $\mathrm{z}$ irányban is Angströmös pontosságú pozícionálás valósítható meg. A tü és a felület közötti érintkezéskor taszító és vonzó kölcsönhatások lépnek fel, melyek a felület topográfiájától függően meghajlítják a torziós lapkát. A deformációt a rajta reflektált lézersugár irányból való kitérése jelzi. A minta pásztázása során közel atomi felbontással rajzolódik ki a felület topográfiai képe. A legelterjedtebb AFMmérési módok a kontakt- és kopogtató-üzemmódok. Kontakt üzemmód esetén a tủ hozzáér a mintához és a laprugó a pásztázás közben a minta domborzatát követve változó mértékben hajlik meg. Kopogtató üzemmód esetén a tü meghatározott frekvenciával rezeg és a rezgés során a minta valamint a tű csak részben, vagy egyáltalán nem ér össze, ilyenkor a Van der Waals jellegű kölcsönhatási erők hatását érzékeljük. Mindkét módszernél a pásztázott felület $\mathrm{x}$, y koordinátáihoz tartozó z irányú elmozdulás egy színskála alkalmazásával topográfiai térképpé alakítható.

A C és Ti rétegek vastagságának mérésére egy Nanoscope Multimode 8 típusú atomerő mikroszkópot alkalmaztunk kontakt üzemmódban. 


\subsubsection{Raman spektroszkópia (RS) és Közeli infravörös gerjesztett Raman spektroszkópia}

(NIRS)

A Raman spektroszkópia (RS) a nanoszerkezetű anyagok vizsgálatának fontosabb, nem roncsoló rezgési spektroszkópiai módszere, az infravörös spektroszkópia (IR) kiegészítő technikája. A közeli infravörös gerjesztett RS (NIRS) mérés során monokromatikus lézernyalábbal sugározzuk be a mintát. A beeső fotonok egy fókuszáló optikai rendszeren, mikroszkópon keresztül a mintára esnek, majd azok egyes rezgéseivel kölcsön hatva rugalmatlanul szóródnak. A szóródott fotonok energia eltolódását detektálva következtetni tudunk a minta rezgési módusaira, valamint információt kaphatunk a mintában található kötésekről. A molekula egy adott rezgésének Raman-aktivitása attól függ, hogy a rezgés során megváltozik-e a molekula elektromos polarizálhatósága. Míg az aszimmetrikus, poláros kötések IR-aktívak, addig a szimmetrikus és homopoláris kötések Raman-aktívak. A NIRS a szén összes allotróp módosulatára érzékeny technika, vagyis kiválóan alkalmas amorf szén rétegek jellemzésére.

A TiC/a:C vékonyrétegek amorf részének jellemzését egy 488 nm-en müködő Ar-ion gázlézerrel, valamint egy $785 \mathrm{~nm}$ hullámhosszú diódalézerrel felszerelt Renishaw1000 B típusú mikro-Raman mikroszkóppal végeztük a $100-1700 \mathrm{~cm}^{-1}$ hullámszám tartományban. A réteg által visszavert fényt egy rácsra fókuszáltuk, mely a spektrumot egy CCD kamerára vetítette. A Renishaw $1000 \mathrm{~B}$ típusú müszerrel a rács folyamatos mozgatása közben tudtuk regisztrálni a spektrumot, ezzel minden hullámhosszal végigpásztázva a CCD felületét, vagyis a kamera felületén lévő esetleges hibák kiátlagolódtak, miáltal a jel/zaj viszony is kedvezőbb lett.

\subsubsection{Fotoelektron spektroszkópiai (PES) módszerek}

A fotoelektron spektroszkópiai (PES) módszerek szilárd felületek, gáz- és folyadék minták vizsgálatára alkalmas ionizációs spektroszkópia módszerek, melyek során a mintát nagy energiájú (távoli ultraibolya, vagy röntgen) monokromatikus fénnyel sugározzuk be a felszíni atomok elektronjainak kilökésére, az atomok ionizálására. Az anyag felületét érő sugárzás hatására az anyagból fotoelektronok lépnek ki. Ha az ionizáló sugárzás röntgenfény, a belső héjakon lévő elektronok leszakítása is megvalósulhat. Az eljárások mindegyike ultranagy vákuum (nagyjából $10^{-9}$ mbar) térben zajlik a szén szennyezésének kiküszöbölése érdekében. A kiszakadó elektronok kinetikus energiáját mérjük, melyből kiszámítható az 
ionizációt kísérő energiaváltozás. A kilépő fotoelektronok energia spektrumát rögzítjük. Az információs mélységet a detektált elektronok energiája, valamint a vizsgálandó anyag milyensége határozza meg. A PES fő típusa a Röntgen fotoelektron spektroszkópia (XPS).

Az XPS egy felület analitikai módszer, amely alkalmas az egyes elemek specifikus megkülönböztetésére. Vékonyrétegek növekedésének tipikus vizsgáló módszere. Az XPS mért összetételre vonatkozó információs mélysége anyagi minőségtől függően és az elektronok rugalmatlan közepes szabad úthosszából adódóan TiC-ra 2,5 nm $\pm 0,5 \mathrm{~nm}$. Munkám során tehát a TiC/a:C vékonyrétegek átlagos kémiai összetételének vizsgálatára alkalmaztuk. A háttérnyomás $1 \times 10^{-9}$ mbar volt, mely az Ar ion bombázás során $2 \times 10^{-7}$ mbar nyomásra emelkedett. Gerjesztő forrásként az imént említett úthosszhoz tartozó 1486,7 eV energiájú Al anódú röntgencsövek karakterisztikus vonalait használtuk. A módszerrel a mintában előforduló elemeket, valamint azok kémiai kötéseit a röntgenfotonok által kiváltott fotoelektron csúcsok energiáinak és intenzitásainak mérésével azonosítottuk. $5 \times 5 \mathrm{~mm}^{2}$ nagyságú mintákat vágtunk ki, melyeket ráillesztettünk egy nagyobb darab Si hordozóra s betettük a vákuumtérbe analizálni. A rétegek belső összetételének vizsgálatához a rétegek tetején található, spontán képződött natív oxid-réteget a mérést megelőzően Ar ionbombázással eltávolítottuk. Az Ar ionbombázás hatására azonban az addig stabil TiC/a:C felület aktívnak mutatkozott, minek következtében a vákuum környezetböl lassú grafit típusú szén felhalmozódása volt megfigyelhető. Ennek elkerülésére, különös figyelmet fordítottunk a megfelelő porlasztási körülményekre. A rétegek legfelső felületében a lehetséges összetétel változás korlátozására, $80^{\circ}$-os beesési szög mellett alacsony energiás $(1 \mathrm{keV})$ Ar ionsugárzást alkalmaztunk. Minden mérés során állandó energia felbontást $(1,5 \mathrm{eV})$ használtunk. Az XPS spektrumokat egy speciális előfékezéses hengeres tükör analizátorral (DESA 105; gyártója Staib Instruments Ltd.) detektáltuk. Az ionnyalábbal az egész minta felületét egyenletesen végigpásztáztuk. A rétegek összetételének fő XPS vonalai a következők: 284,4 eV-nál C-1s, 454,0 eV-nál Ti-2p 1/2 + 3/2, 530,0 eV-nál O-1s és 242 eV-nál Ar-2p. A vonal-intenzitásokat Shirley háttérlevonást követően a csúcs alatti területekből Gauss/Lorentz csúcsillesztésekkel számoltuk ki. A csúcsillesztések ugyanakkor lehetővé tették a $\mathrm{C}$ vonal felbontását a különböző kötési energiákkal rendelkező amorf szén és karbid csúcsokra (a kötési energiák közti különbség 2,2 eV). Azon minták esetében melyek lényegesen kevesebb amorf szenet tartalmaztak egy intenzívebb karbid csúcs mellett, a pontos mérés eléréséhez hosszabb adatgyüjtési időt (2 - 4 óra) alkalmaztunk. A pontos összetételt a szakirodalomban megtalálható [116] érzékenységi tényezők használatával határoztuk meg. 


\subsubsection{Keménységmérések}

A statikus keménység fogalma alatt a vizsgált anyag ellenállását értjük az adott geometriájú szúrószerszám benyomódásával szemben. A makroszkópikus méretekben legelterjedtebb keménységmérési módszerek közé a Brinell-keménységmérés, Vickerskeménységmérés, Knoop-keménységmérés, Rockwell-keménységmérés és a különböző dinamikus keménységmérő eljárások, mint pl. Poldi-kalapáccsal történő mérések tartoznak. Vékonyrétegek, bevonatok esetében azonban az említett módszerek nanométeres benyomódási mélységekre kidolgozott változata, az ún. nanoindentáció használatos, ahol a nanoindentor egy módosított atomerő mikroszkópnak tekinthető. Ez a módszer lehetővé teszi a vékony, nanoszerkezetü rétegek helyi rugalmas tulajdonságainak, valamint keménységértékeinek meghatározását. A nanoindentációs mérések során szabványos Vickers-, vagy Berkovich-tetraéder geometriájú mérőfejeket használnak szúrószerszámként és a mérőfej benyomódási mélységeit egy számítógép rögzíti. Ahogy azt a 8. ábra is jól szemlélteti, a benyomódásnak egy terhelő és egy visszaterhelő szakaszát különböztethetjük meg, amelyekre a berendezés terhelőerö-benyomódási mélység görbéket rögzít. Ezekből az adatokból az Oliver - Pharr módszer felhasználásával számíthatjuk ki a rugalmas modulusz és keménység adatokat [117].

A TiC/a:C vékonyrétegek mechanikai tulajdonságainak jellemzését egy Nanoindenter Agilent G200 (USA) Bekovich típusú tetraéder alakú gyémánt benyomófejjel felszerelt berendezéssel végeztük szobahőmérsékleten. A terhelőerö-benyomódási mélység görbékből származtatott keménység és Young modulusz értékeket az Oliver és Pharr módszerrel értékeltem ki. A hordozó hatásának elválasztására és a réteg tulajdonságainak megállapítására, a folyamatos terhelés, benyomódás és merevség értékek regisztrálásához folyamatos merevség mérés (CSM) módot alkalmaztunk $500 \mathrm{~nm}$-es mélységi határral és 50 mN-os maximális terheléssel. Az így kapott intervallumból a rétegekre jellemző értékeket a teljes rétegvastagság $10 \%$-ánál, vagyis 10 - 20 nm mélységnél, $1 \mathrm{mN}$-os terhelésnél olvastam le. A mérések elvégzéséhez szabad szemmel láthatóan tiszta területek kerültek kiválasztásra, majd mindegyik mintán 4 x 4 benyomást végeztünk el. Mivel a kb. 102 - 180 nm vastagságú rétegeket $300 \mathrm{~nm}$ vastag $\mathrm{SiO}_{2}$-re porlasztottuk, a mérések megkezdése elött a tüt kvarcüveg referencia mintán kalibráltuk. A CSM mód során mélység vezérlési üzemmódot használtunk szabványos terhelési sebességgel $(\varepsilon), 45 \mathrm{~Hz}$-es frekvenciával, 2 nm-es amplitúdóval és a céltárgy 0,05 1/s-os alakváltozási sebességével. A gyémánt hegy Young modulusz és Poisson tényező paraméterei $\mathrm{E}_{\text {hegy }}=1141 \mathrm{GPa}$ és $v_{\text {hegy }}=0,07$ voltak. Az eltérő mennyiségü titánt 
tartalmazó vékonyrétegek mikroszerkezetében történő benyomódás helyétől függően a benyomási mélység és az indentációs keménység értékek eltérőnek adódtak, vagyis minél puhább a minta, minél kevesebb titánt tartalmaz, annál mélyebbre képes benyomódni a tü.

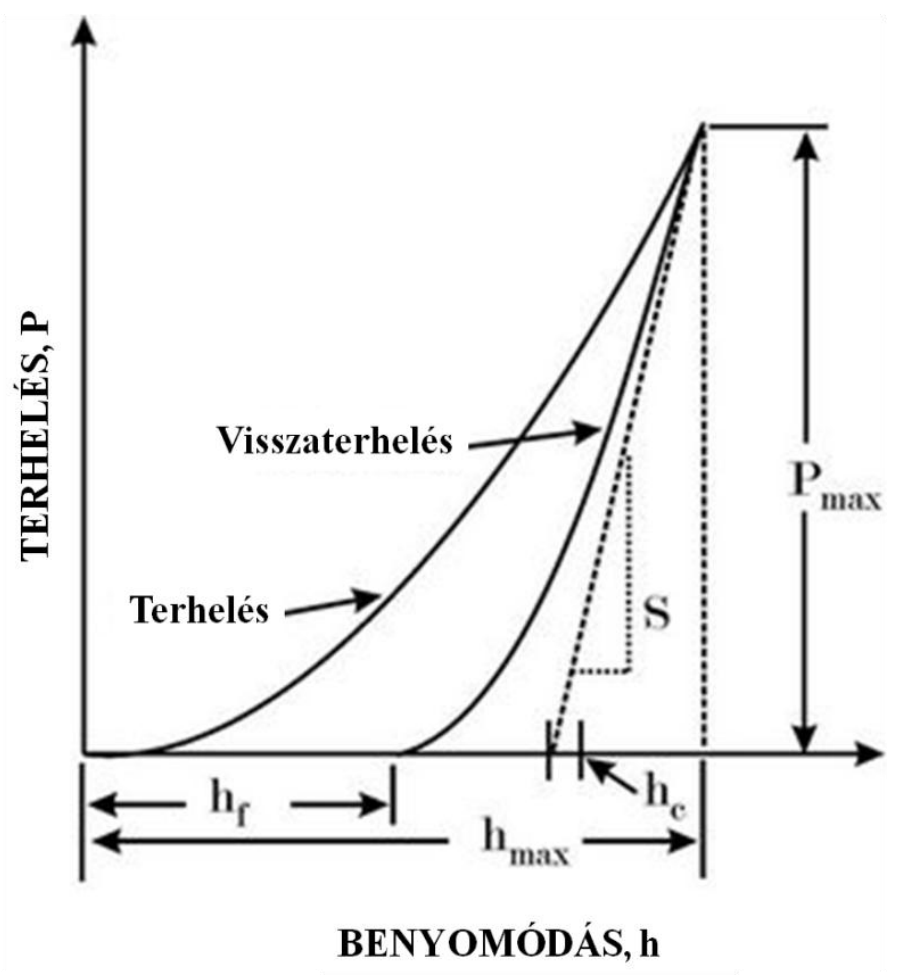

8. ábra: Egy nanokeménységmérés vázlatos ábrázolása a terhelés és a benyomófej benyomódási mélység adatainak függvényében. Az ábrán a következö mennyiségek láthatóak: $P_{\max }$ : legnagyobb csúcsterhelés; $\boldsymbol{h}_{\max }$ : a csúcsterhelés legnagyobb benyomódási mélysége a terhelési ciklus során; $h_{f}$ : maradó benyomódási mélység a visszaterhelés után; $h_{c}$ : függöleges távolság, amely mentén az érintkezés létrejön (érintkezö mélység) és $S:$ a kezdeti visszaterhelés merevsége [117].

\subsubsection{Tribológiai mérések}

A mesterséges koptatás méréséhez „ball-on-disk” elrendezésü CSM Instruments gyártmányú tribométert (9. ábra) használtunk, amely automatizáltan képes végrehajtani nagyon hosszú koptatási feladatokat. Méréseinket szobahőmérsékleten, levegő atmoszférán $0,05 \mathrm{~m} / \mathrm{s}$ csúszási sebesség mellett végeztük. A vizsgálandó mintadarabot egy cirkuláris pályán forgó tárcsára erősítettük és $2 \mathrm{~N}$ nagyságú merőleges erővel $5 \mathrm{~mm}$ átmérőjü $\mathrm{Si}_{3} \mathrm{~N}_{4}$ kerámia golyót nyomtunk a felületére. A rögzített tengelyü golyó a korongon csúszott így idézve elő kopást, míg a korongot egy motor segítségével különböző sebességgel forgattuk. A 
próbatestek vizsgálatához egy olyan zárt rendszert (fülke) biztosítottunk, amelyben a környezet paraméterei - különös tekintettel a relatív páratartalomra - szabályozhatóak voltak. A golyót úgy rögzítettük, hogy kizárható legyen bármilyen másfajta forgó mozgás, pl. gördülés, tehát tiszta súrlódás valósuljon meg a golyó és a sík felület között. Így ismerve a geometriai paramétereket és a merölegesen ható erő nagyságát, kiszámíthattuk a rétegünkre jellemző kopási rátát, vagyis a 3000 ciklus utáni egységnyi erő hatására elkoptatott anyagmennyiséget.

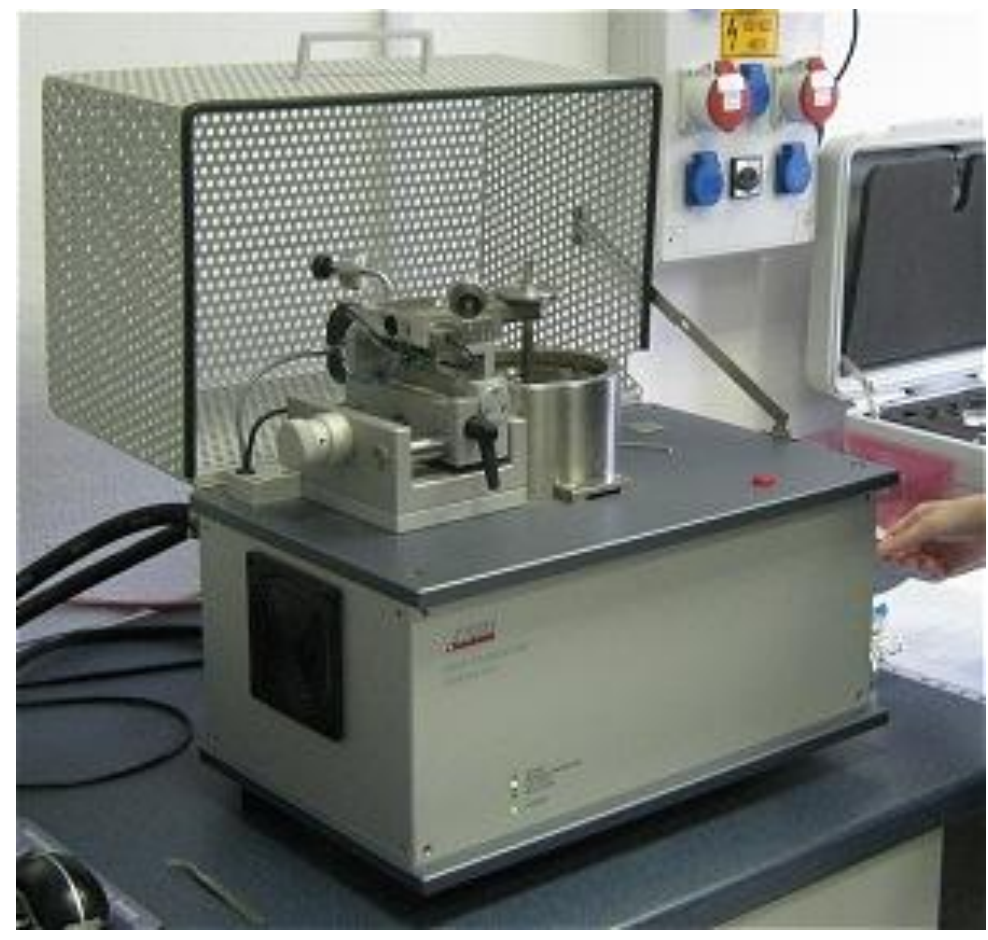

9. ábra: Az általunk használt CSM gyártmányú tribométer.

\subsubsection{Korróziós tulajdonságok vizsgálata}

A potenciodinamikus és Elektrokémiai Impedancia Spektroszkópia (EIS) vizsgálatokat Zahner IM6e elektrokémiai potenciosztáttal (Zahner - Elektromos Kft., Németország), standard háromelektródos cellában (10. ábra), $0,5 \mathrm{mV} \mathrm{s}^{-1}$ sebességü potenciálléptetéssel levegő atmoszférában hajtottuk végre. Munkaelektródokként bevonat nélküli és TiC/a:C vékonyréteggel bevont sima, csiszolt TiAl6V4 (ISO5832-3), szemcseszórt TiAl6V4 (ISO5832-3), sima, csiszolt Ti (ISO5832-2) és szemcseszórt felületű CoCrMo (ISO5832-12) fém implantátum korongok szolgáltak. A szemcseszórt felületü TiAl6V4 és CoCrMo korongok $20 \mathrm{~mm}$ átmérőjüek, $2 \mathrm{~mm}$ vastagok, a sima, csiszolt TiAl6V4 és Ti 
korongok $35 \mathrm{~mm}$ átméröjüek és $2 \mathrm{~mm}$ vastagok voltak. Az elektrokémiai mérések során a munkaelektród aktív felülete a szemcseszórt korongok esetén 1,37 cm², míg csiszolt minták esetén $3 \mathrm{~cm}^{2}$ volt, ahol az aktív felületek különbsége a hordozók méretének különbségéből adódott. A kapott korróziós áramokat minden esetben egységnyi felületre normalizáltuk.

Az első mérések során 3 féle elektrolitot - 0,5 M NaCl $(\mathrm{pH}=6) ; 0,1 \mathrm{M} \mathrm{HCl}(\mathrm{pH}=1)$ és $0,1 \mathrm{M} \mathrm{NaOH}(\mathrm{pH}=13)$ - használtunk $\mathrm{Ag} / \mathrm{AgCl} / \mathrm{KCl}_{\text {sat }}$ referencia elektród és Pt háló, mint segédelektród alkalmazása mellett. A második mérést $37^{\circ} \mathrm{C}$-on SBF-ben $(\mathrm{pH}=7,4)$ hajtottuk végre $\mathrm{Hg} / \mathrm{Hg}_{2} \mathrm{Cl}_{2}$ telített kalomel referencia elektróddal és Pt háló segédelektróddal. A vizsgálatokat minden esetben egy egyenletes nyitott áramköri potenciál elérése után kezdtük meg (a potenciálváltozás 5 perc alatt nem volt több mint $\pm 5 \mathrm{mV}$ ).

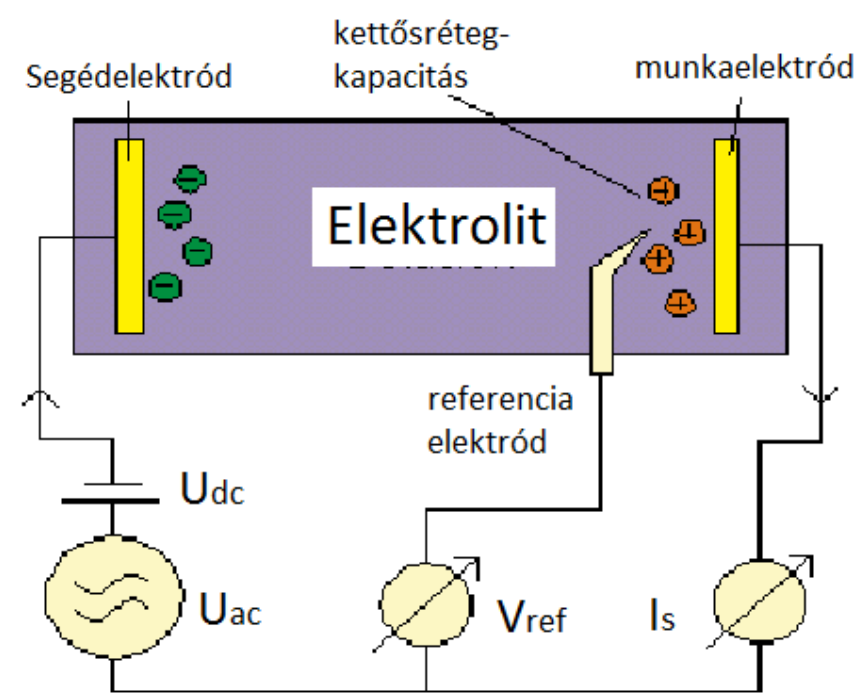

\section{0. ábra: A háromelektródos cella felépítésének sematikus ábrája.}

Az EIS egy nagyon hasznos roncsolásmentes technika a bevont és bevonat nélküli sebészeti implantátum anyagok korróziós viselkedésének, valamint a védőréteg stabilitásának vizsgálatára. A mérések frekvenciatartománya $100 \mathrm{kHz}$ kezdeti frekvenciáról $10 \mathrm{mHz}$ frekvenciáig terjedt. Az EIS méréseket a különböző oldatokban lévő munkaelektródok nyitott áramköri potenciáljával, szobahőmérsékleten $10 \quad \mathrm{mV}$ amplitúdójú szinuszos váltófeszültséggel végeztük. Az impedancia spektrumok elemzésére és a töltésátviteli ellenállás értékek $\left(\mathrm{R}_{\mathrm{ct}}\right)$ megbecsülésére elektromos helyettesítő áramköröket (EEC) [4], míg az impedancia adatok kiértékelésére Zview2 szoftvert használtunk. 


\subsubsection{Induktív Csatolású Plazma Optikai Emissziós Spektrometria (ICP-OES)}

Annak érdekében, hogy megállapítsuk az esetlegesen jelenlévő fémionok mennyiségét a testnedv folyadékokban, a $\mathrm{TiC} / \mathrm{a}: \mathrm{C}$ réteggel fedett, illetve a réteg nélküli, alap hordozók kioldódási tulajdonságait ICP-OES müszeres analitikai módszerrel vizsgáltuk. A módszer egy induktív csatolású plazma segítségével állítja elő a gerjesztett atomokat és ionokat, melyek aztán az adott kémiai elemre jellemző hullámhosszúságú elektromágneses sugárzást bocsátanak ki. Az emittált sugárzás intenzitása kapcsolatban van a mintában előforduló elem koncentrációjával. Az ICP-OES módszer kimutatási határa jellemzően a ppb (milliárdod rész) tartományba esik és a periódusos rendszer legtöbb eleme érzékenyen mérhető vele.

A potenciálisan felszabadult fémion $(\mathrm{Ti}, \mathrm{Al}, \mathrm{V})$ koncentrációt, valamint az egyéb, SBF folyadékokból visszamaradt ion koncentrációt (Ag, Ca, Cu, Fe, K, Mg, Mn, Na, Ni, P, S, $\mathrm{Si}, \mathrm{Sr}$ ésZn) egy tengelyirányú plazmával és CCD detektor rendszerrel (175 - $775 \mathrm{~nm})$ felszerelt Spectro Genesis típusú berendezéssel azonosítottuk. 


\section{KÍSÉRLETI EREDMÉNYEK}

\subsection{TiC/a:C nanokompozit vékonyrétegek szerkezeti vizsgálata}

Kísérleteim kezdetén a TiC/a:C nanokompozit vékonyrétegek porlasztása szobahőmérsékleten, argon atmoszférában szilícium ( $\mathrm{Si}$ ) egykristályra (001) növesztett, 300 nm vastagságú, oxidált amorf Si-O felületre történt. A rétegeket DC magnetronos porlasztó rendszerben, egy egymással szemben elhelyezkedő Ti és $\mathrm{C}$ céltárgy egyidejü porlasztásával hoztam létre. Az egyes rétegek összetételét a Ti céltárgy teljesítményének módosításával változtattam 5 és $150 \mathrm{~W}$ között. A másik változtatható paraméter az idő volt, mellyel a rétegek vastagságát szabályoztam. Ahogy az 1. táblázat is mutatja, 25 - 30 perc alatt átlagosan $90 \div 330 \mathrm{~nm}$ vastagságú rétegek képződtek a titán céltárgy teljesítményének függvényében.

Olyan esetben, ha a porlasztás folyamán nem áll rendelkezésre rétegvastagság mérési lehetőség, az alkotók egyéni porlódási sebességének ismeretében közelítő becslést kaphatunk a nanokomopozit réteg időarányos vastagságáról. Mivel az általam használt berendezésben nem állt rendelkezésre vastagságmérő eszköz, az esetleges kalibráció, valamint külön a titán és külön a szén növesztési sebességének megállapítására egy $\mathrm{C} / \mathrm{Ti} / \mathrm{C} / \mathrm{Ti} / \mathrm{C} / \mathrm{Ti}$ multiréteget készítettem $\mathrm{Si} / \mathrm{SiO}_{2}$ hordozóra $100 \mathrm{~W}$ C és Ti teljesítmény mellett 300/300/600/600/900/900 másodperces időközökkel. A kapott növesztési sebességeket szintén az 1. táblázatban mutatom be. Mivel a C teljesítményét nem változtattam, ezért csak a $150 \mathrm{~W}$ C teljesítményre vonatkozó porlódási arányt adtam meg, mely $0,41 \AA / s$. A leválasztott réteg vastagsága minden esetben arányos a porlasztás teljesítményével és a porlasztási idővel.

A TEM vizsgálatokhoz a mintákat a fentiekben már részletezett, ionsugaras vékonyítással keresztirányban vékonyítottam ki. A $\quad \mathrm{SiO}_{2} / \mathrm{Si}$ hordozóra a vékonyítás egyszerüsége miatt esett a választás.

Az 1. táblázatban foglalt összes rétegen XPS elemzést végeztünk, hogy feltárjuk összetételüket és a kémiai kötések típusát tanulmányozzuk. A detektált szénjelet karbid és elemi szén részekre bontottuk, melyek a TiC és amorf $\mathrm{C}$ fázisokhoz tartoznak. A rétegek karbid frakcióból, valamint amorf részből álló C és Ti koncentrációi közötti összefüggéseket a 11. ábra szemlélteti. 


\begin{tabular}{|c|c|c|c|c|c|}
\hline $\begin{array}{l}\mathrm{P}_{\mathrm{Ti}} \\
(\mathrm{W})\end{array}$ & $\begin{array}{c}\mathrm{t} \\
\text { (perc) }\end{array}$ & $\begin{array}{c}\text { Rétegvastagság } \\
\text { (nm) }\end{array}$ & $\begin{array}{c}\text { A TiC } \\
\text { szemcsék } \\
\text { átlagos } \\
\text { mérete }(\mathrm{nm})\end{array}$ & $\begin{array}{l}\text { A TiC oszlopok } \\
\text { vastagsága } \\
\text { (nm) }\end{array}$ & $\begin{array}{l}\text { A Ti növesztési } \\
\text { sebessége }(\AA / s)\end{array}$ \\
\hline 5 & 30 & $102 \pm 11$ & 0 & - & 0,08 \\
\hline 10 & 30 & $105 \pm 2$ & 0 & - & 0,16 \\
\hline 15 & 30 & $96 \pm 2$ & $0,5-1$ & - & 0,24 \\
\hline 20 & 30 & $121 \pm 5$ & 1 & - & 0,32 \\
\hline 25 & 30 & $135 \pm 6$ & $1-2$ & - & 0,4 \\
\hline 30 & 30 & $113 \pm 4$ & $2-6$ & - & 0,48 \\
\hline 35 & 30 & $153 \pm 6$ & - & $4-8$ & 0,56 \\
\hline 40 & 30 & $137 \pm 5$ & - & $4-10$ & 0,64 \\
\hline 45 & 28 & $144 \pm 2$ & - & $6-17$ & 0,72 \\
\hline 50 & 28 & $158 \pm 7$ & - & $9-16$ & 0,8 \\
\hline 55 & 28 & $146 \pm 2$ & - & $14-19$ & 0,88 \\
\hline 60 & 25 & $152 \pm 5$ & - & $10-21$ & 0,96 \\
\hline 65 & 25 & $169 \pm 2$ & - & $10-23$ & 1,04 \\
\hline 70 & 25 & $180 \pm 12$ & - & $10-26$ & 1,12 \\
\hline 85 & 25 & $200 \pm 3$ & - & $*$ & 1,36 \\
\hline 100 & 25 & $200 \pm 20$ & - & $*$ & 1,6 \\
\hline 120 & 25 & $280 \pm 25$ & - & $*$ & 1,92 \\
\hline 150 & 25 & $331 \pm 3$ & - & $*$ & 2,4 \\
\hline
\end{tabular}

1. táblázat: A keresztmetszeti TEM képekböl becsült adatok a bevonat vastagságára, valamint a TiC nanokristályok átlagos méretére és vastagságára vonatkozólag a Ti teljesítmény és porlasztási idö függvényében. * Nem állapítható meg. 


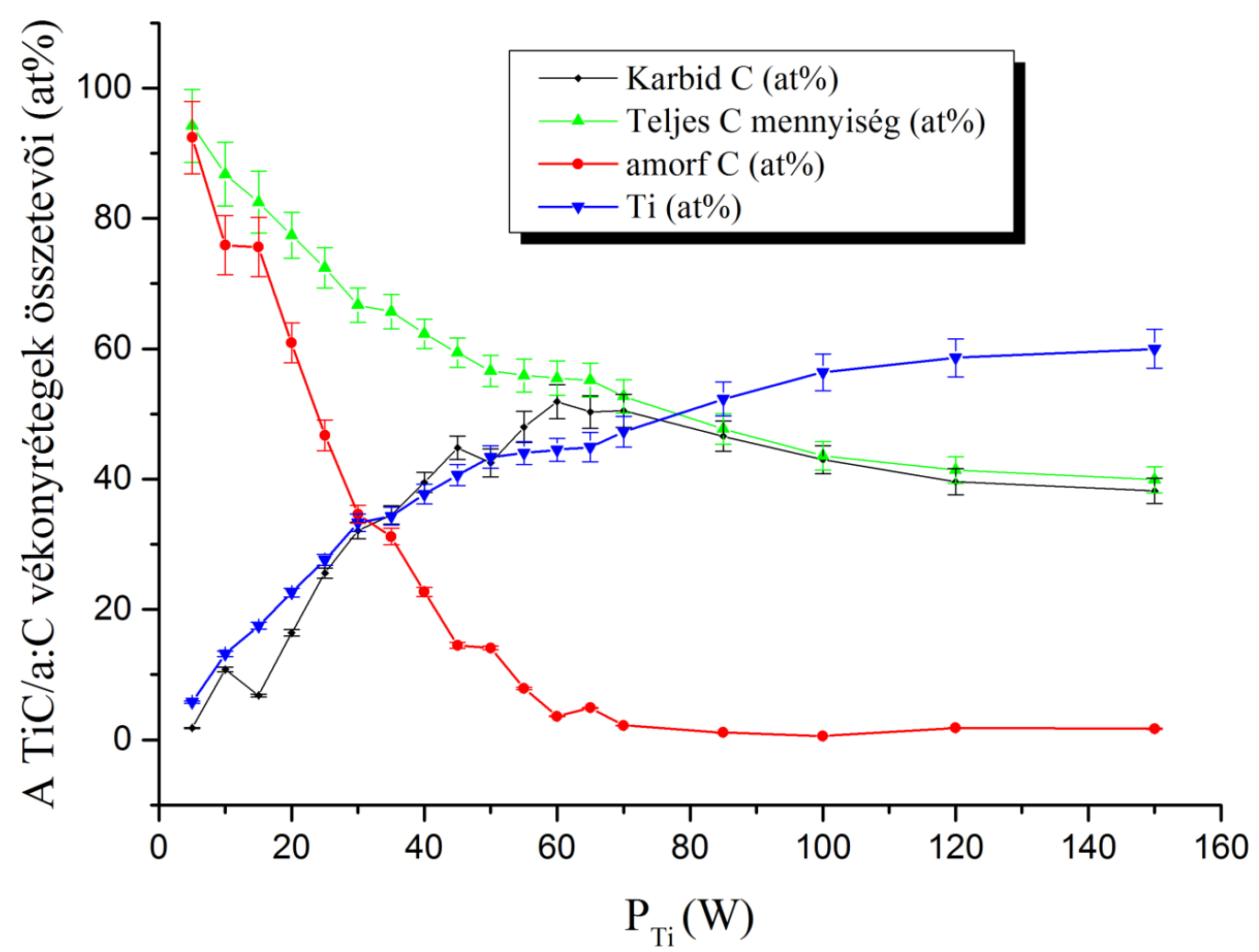

\section{1. ábra: A TiC/a:C vékonyrétegek összetevöinek az XPS csúcsok illesztéséböl} meghatározott koncentrációi a különbözö Ti céltárgy teljesítmények függvényében.

A Ti teljesítmény növelésével a Ti tartalom növekvő tendenciája figyelhető meg a kialakult vékonyrétegekben (11. ábra). A mérések alapján kimutatható, hogy még a kb. 47 at\% $\left(\mathrm{P}_{\mathrm{Ti}}=70 \mathrm{~W}\right)$ Ti tartalmú réteg esetében sem elegendő a Ti mennyiség ahhoz, hogy az egész szénmennyiséget megkösse, ami így kétfázisú heterogén (TiC/a:C) rendszert eredményez. Raman és mtsai [45] különböző összetételü, nem sztöchiometrikus Ti - C vékonyrétegeket állítottak elő impulzus DC (Ti céltárgy) és normál DC (grafit céltárgy) magnetronos porlasztás kombinációjával oxidált szilícium és olvasztott kvarc hordozókra. Munkájuk során 7 különböző széntartalmú réteget állítottak elő, melyek közül a 62,5 at\% Cet tartalmazó réteg 34 at\%-a TiC formájában, míg a fennmaradó rész amorf C fázisként volt megfigyelhető. Hasonlóan az esetünkben $5 \mathrm{~W}$ és $70 \mathrm{~W}$ közötti Ti teljesítménynél készült mintákhoz, a kevesebb amorf szenet tartalmazó rétegekben oszlopos növekedést, míg a magas amorf szenet tartalmazó rétegeknél random orientációjú TiC szemcséket mutattak ki (1. táblázat). Megállapították, hogy a kis szemcseméret egyik lehetséges oka a rétegekben jelenlévő nagy mennyiségü többlet szén, mely elszigeteli a TiC kristályokat és megakadályozza azok növekedését [45]. 
Bár az XPS módszerrel a 47 at\% feletti mintákban az amorf szén képződését nem lehet kizárni, mennyisége a módszer érzékenységénél alacsonyabb (11. ábra).

A kétkomponensű Ti - C vékonyrétegekben TEM és HRTEM módszerrel megvizsgáltam a titántartalom hatását a rétegek növekedési mechanizmusára. A TiC/a:C vékonyrétegek növekedésének részletes szerkezeti megfigyelései a 12. ábrán láthatóak. A HRTEM képeken alkalmazott Gyors Fourier Transzformáció (FFT) funkció indirekt információt ad a kristályrács mintázatára vonatkozóan. Az adott zónatengelyek mentén jól orientált kristályos részecskék FFT mintázata megfeleltethető azok határolt területü elektrondiffrakciós (SAED) mintázatának, így a 12. ábrán bemutatott FFT-k az amorf szerkezetek meghatározását, valamint a kristályos mintázatok beindexelését szolgálták. A keresztmetszeti (XTEM) vizsgálataim alapján kialakított kétkomponensü rendszer vázlatos zónadiagramja (SZD) (13. ábra) szemlélteti a porlasztott TiC/a:C bevonatok növekedését.

A képek alapján (12. ábra) elmondható, hogy DC magnetronos porlasztással a szakirodalomban leginkább elterjedt 150 - $350{ }^{\circ} \mathrm{C}$ leválasztási hőmérséklethez hasonlóan a szobahőmérsékleten előállított TiC/a:C vékonyrétegek is követik a kétkomponensű rendszer zónadiagramjára (13. ábra) jellemző morfológiát.

- A HRTEM és FFT vizsgálatok alapján a legkevesebb kb. 6 és 13 at\% titánt tartalmazó rétegek esetében (12a, b. ábra), hasonlóan a zónadiagram 1. részéhez (13. ábra), nem mutatható ki kristályos TiC kialakulása, a rendszerre az amorf fázis jellemző.

- Kristályos fázis először a 17,5 és 34 at\% Ti tartalomnál (12c, d. ábra) jelenik meg. Két elem $(\mathrm{Ti}, \mathrm{C})$ egyidejü porlasztásánál a kialakuló rétegben szegregáció jelenik meg, ha a képződő fázisba be nem épülő (felesleges) adatomoknak a felületi rétegben végbemenő „folyamat-indukálta” kinetikai szegregációjához köti az új „második” fázis képződését. A zónadiagram 2. része (13. ábra) ilyen modell alkalmazásával magyarázható, miszerint a titánba nem képes beépülni a sok szén atom, így felesleges adatomok keletkeznek a TiC felületén, melyek egy idő múlva teljesen körbeveszik, így megállítják a TiC növekedését, mely új magképződéssel kialakítja a következő TiC szemcsét.

- A vázlatos zónadiagram 3. részének megfelelően (13. ábra), az $1-8 \mathrm{~nm}$ átmérőjü kb. $10 \mathrm{~nm}$ vastagságú amorf szénnel fedett globuláris köbös fázisú TiC nanokristályok, 34 - 41 at\% Ti tartalomnál kezdenek megjelenni (12e-g. ábra). 
- A szén mátrixba ágyazott nanométer nagyságú oszlopos TiC kristályok egyre jobban megfigyelhetővé válnak a rétegben létrejövő növekvő titán tartalom miatt (zónadiagram 4. része; 13. ábra). A következő szerkezeti átalakulás nagyjából 41 - 43 at\%-os Ti tartalomnál tapasztalható (12h-j. ábra). A 4 - 16 nm széles, globulárisból oszlopos szerkezetüvé váló TiC nanokristályok között $2-3 \mathrm{~nm}$ vékony amorf szén található. A 43 at\% Ti tartalomnál látható (12j. ábrán) kristályos szemcsék Moiré mintázatai, a TiC oszlopos nanokristályok átfedését jelzik.

- Az oszlopok a zónadiagram utolsó részének megfelelően (13. ábra), a teljes réteget keresztülnövik $44-47$ at\% Ti tartalomnál (12k-n. ábra). Ezeket a rétegeket $8-26 \mathrm{~nm}$ vastag, teljes hosszúságú $1-2 \mathrm{~nm}$ vékony amorf szénnel elválasztott oszlopok jellemzik.

Az FFT bizonyította, hogy a leválasztott rétegekben egyfajta, lapcentrált köbös (fcc) kristályfázisú TiC jelenik meg (12c-n. ábra). A Ti tartalom további növelésével, egészen 60 at\%-ig (13. ábra) a teljes hosszúságú TiC oszlopok közül eltünik az amorf szén és az fcc TiC fázison kívül, egyéb Ti fázis nem alakul ki. A magas titán tartalmú rétegek SAED vizsgálatánál az amorf szénre jellemző 002 diffúz vonal nem figyelhető meg (14. ábra). 

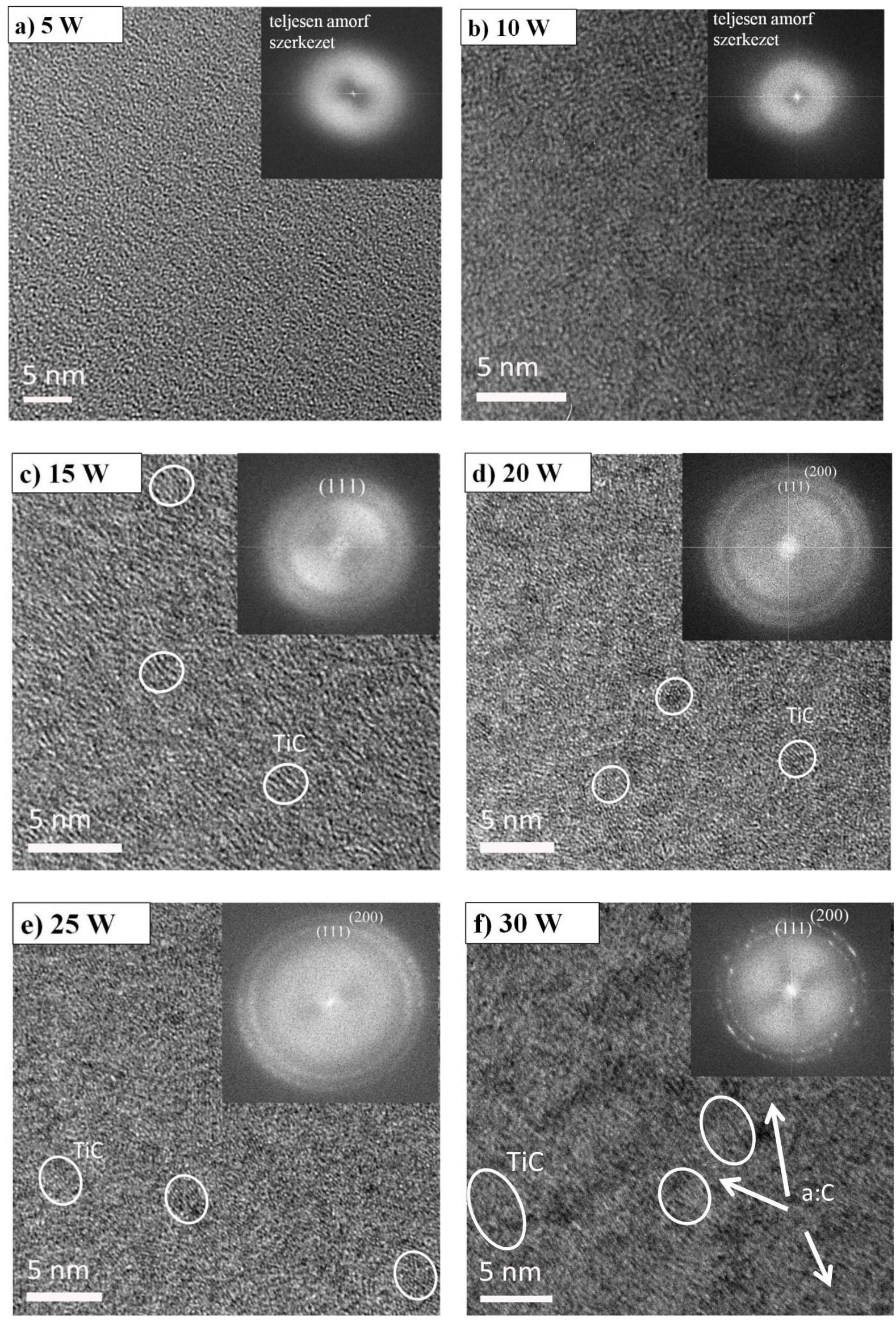

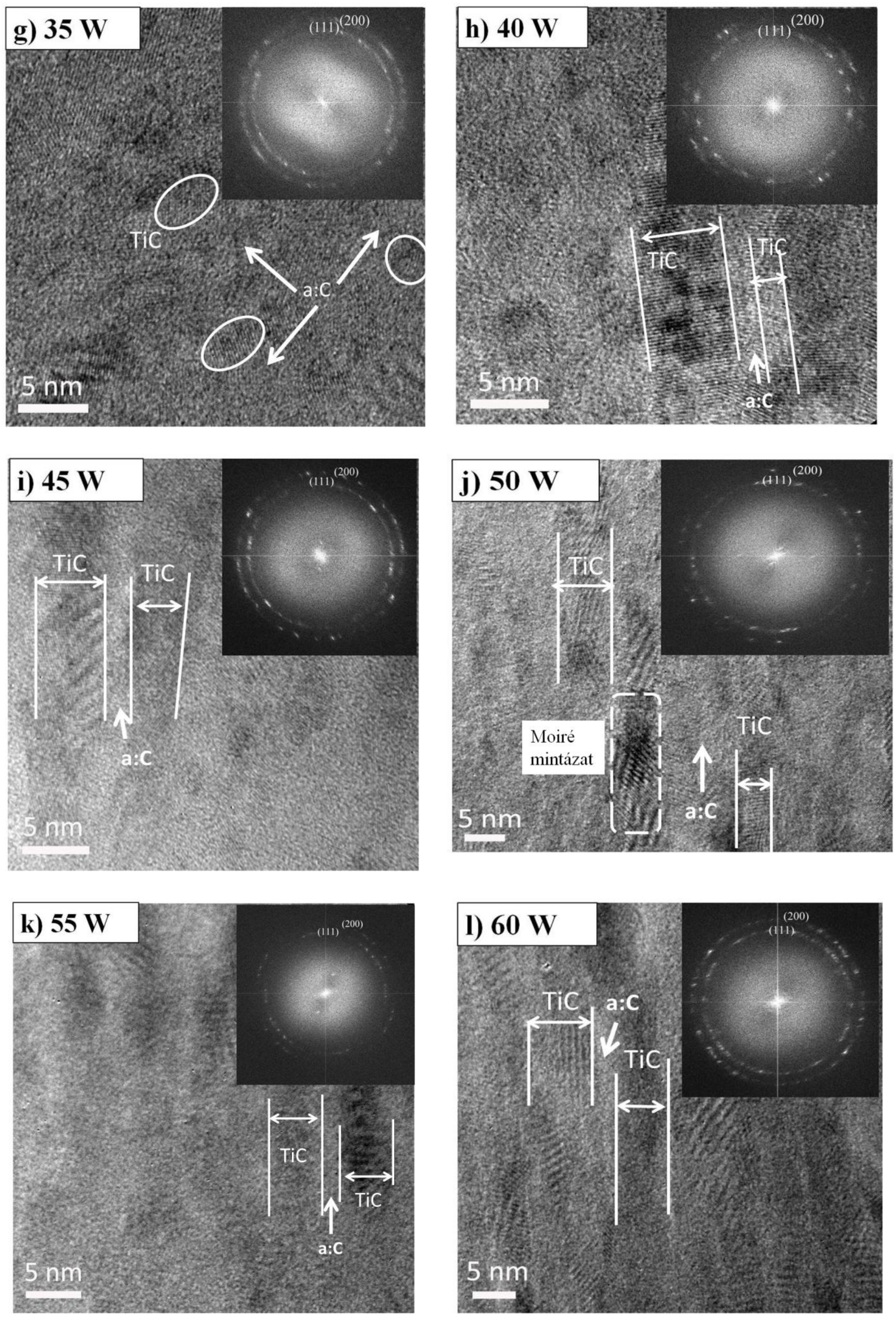

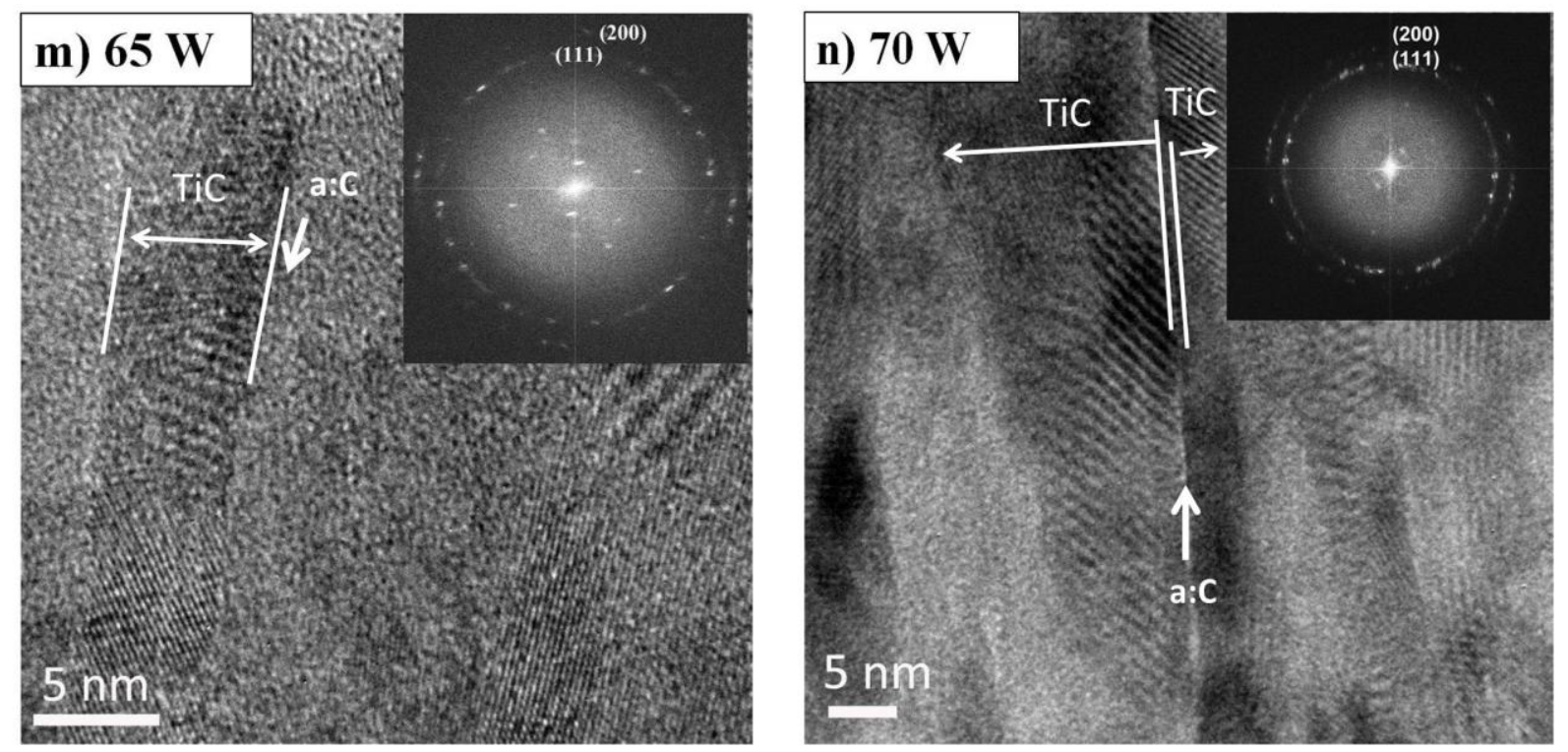

12. ábra: A különbözö Ti forrás teljesítményeknél porlasztott TiC/a:C rétegek keresztmetszeti szerkezeti vizsgálatának HRTEM képei és azok Fourier-transzformáltja a rétegek egészére vonatkozólag. a) 6 at\%, b) 13 at\%, c) 17,5 at\%, d) 23 at\%, e) 28 at\%, f) 33 at\%, g) 34 at\%, h) 38 at\%, i) 41 at\%, j) 43 at\%, k) 44 at\%, l) 44,5 at\%, m) 45 at\% és n) 47 at\% Ti tartalmú rétegek.

Az 1. táblázat eredményeit a HRTEM, FFT (12. ábra), zónadiagram (13. ábra) és SAED (14. ábra) által kapott eredményekkel összevetve látható, hogy a rétegek növekvő Ti tartalmával a TiC kristályok is növekvő tendenciát mutatnak. Eközben az őket befedő, majd a későbbi szerkezetátalakulások során őket elválasztó amorf szén mennyisége lecsökken, míg nagyjából 52 at\% feletti Ti tartalomnál teljesen megszünik. 


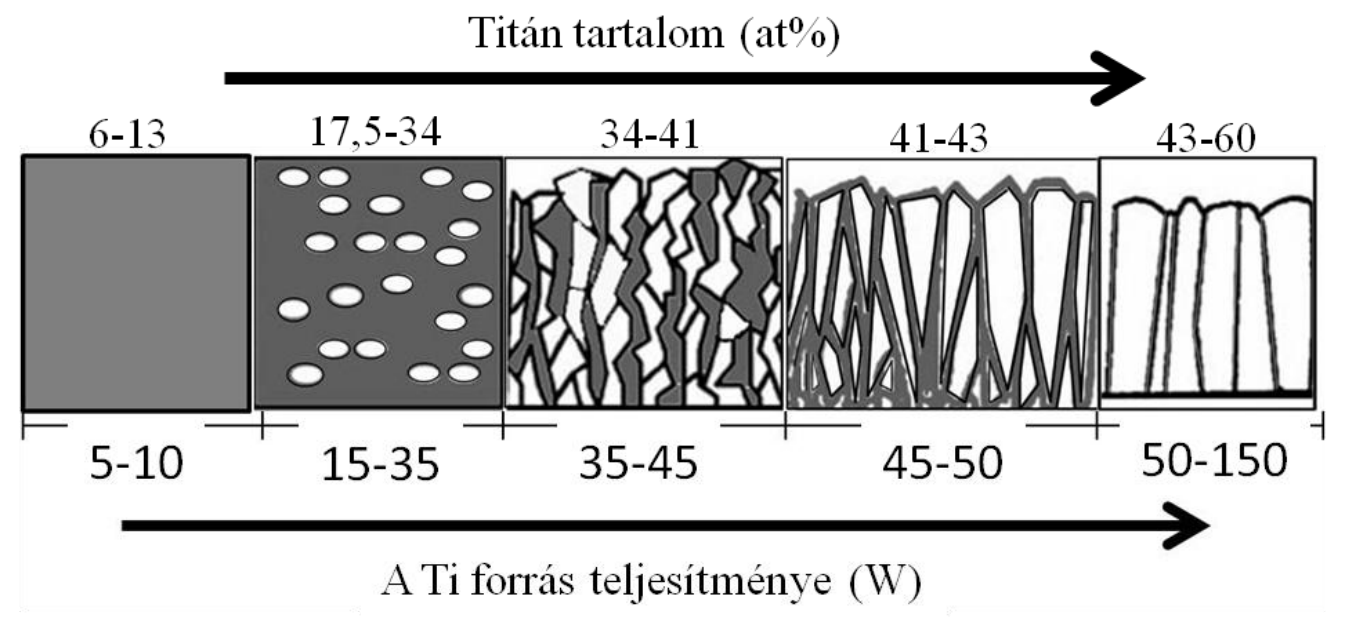

13. ábra: Az XTEM vizsgálatok alapján kialakított kétkomponensü rendszer (TiC/a:C) vázlatos zónadiagramja, a második komponens (a:C) térfogathányadába belépö elsö komponens (TiC) függvényében (fehér - TiC szemcsék/oszlopok, szürke - amorf szén).

a) 52 at $\%$

c) 58,5 at $\%$

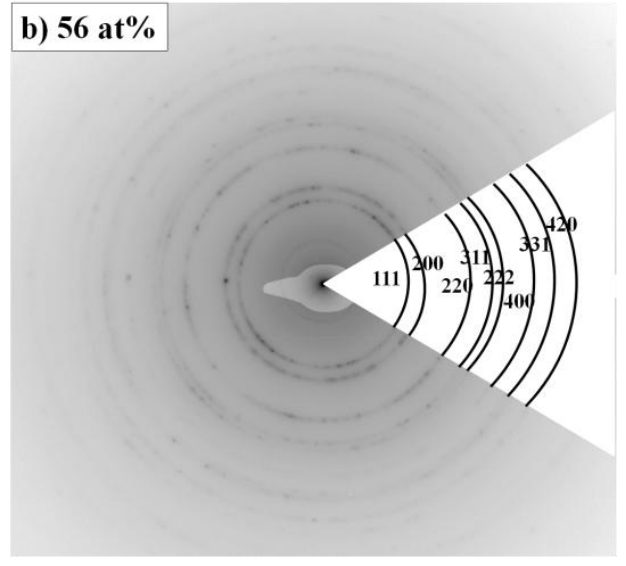

d) $60 \mathrm{at} \%$
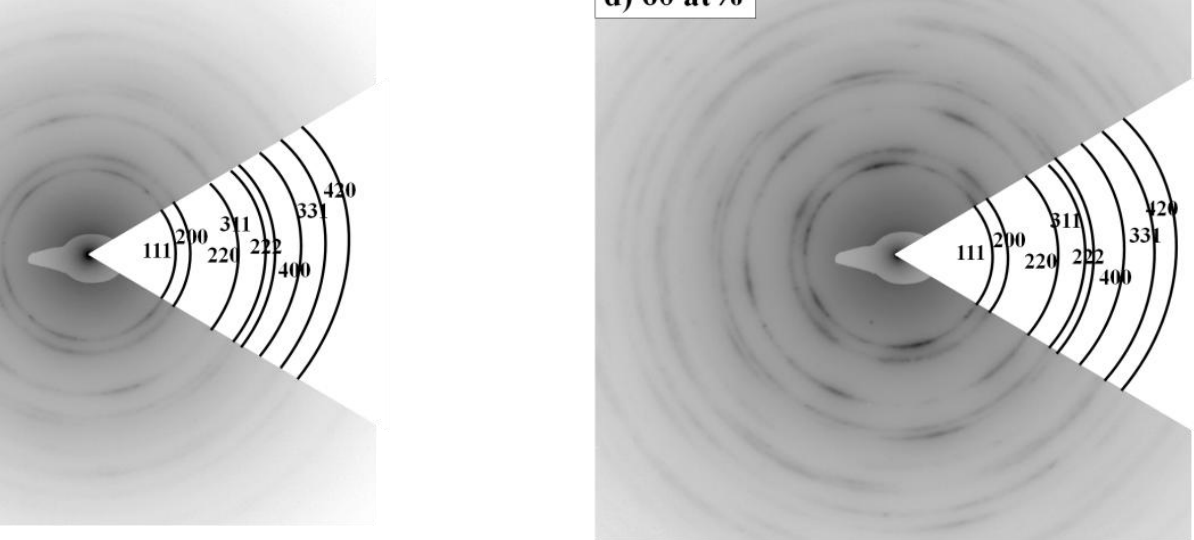

14. ábra: A TiC/a:C vékonyrétegek legmagasabb Ti tartalomnál készült SAED felvételei. 
A magasabb Ti koncentrációjú TiC/a:C rétegeknél (47 at\%-tól kezdődően) az <111> textúra fejlődése mellett az oszlopos szemcsék átméröjének növekedését is megfigyelhetjük (1. táblázat, 14. és 15. ábra). A 60 at\% Ti tartalmú réteg esetében teljes réteghosszúságú TiC oszlopok képződnek. A köbös fázis mellet nem alakul ki más minor fázis, pl. hcp titán.

A 15. ábrán bemutatom a 6,38 és 47 at\% Ti tartalomnál készült rétegek szerkezeti vizsgálatát a kémiai kötésekkel (XPS csúcsokkal jellemezve) összevetve. Ezen vizsgálatok célja, hogy még inkább szemléltessék a Ti céltárgy teljesítményétől függő szerkezeti változásokat, amelyek a különböző összetételű rétegek morfológiájában játszódnak le (11. 12. 13. ábra). A szerkezeti vizsgálatok alapján megállapítottam, hogy a porlasztás során használt Ti teljesítmény, azaz a rétegekbe beépített titán mennyisége, szerkezeti átalakuláshoz vezet.

41 at\% Ti tartalomtól a leválasztott rétegekben oszlopos növekedés figyelhető meg. Az oszlopok átmérője a Ti mennyiségének növekedésével kiszélesedik. A Ti tartalom megnövekedésével ugyanakkor az amorf szén mátrix vastagsága 10 nm-ről 1 - 2 nm-re csökken és grafitos szén jelenléte nem tapasztalható, miközben a nanokristályok 0,5 nm-es méretről 26 nm-es nagyságúra növekednek (1. táblázat és 12. ábra).

A legkevesebb Ti-t tartalmazó első minta esetében (6 at\% Ti; 15a. ábra) az amorf szerkezet dominál; a $102 \pm 11 \mathrm{~nm}$ vastag rétegben nanokristályok nem mutathatóak ki. Ahogy a titántartalom növekszik (38 at\% Ti), a globuláris szerkezet is megfigyelhetővé válik, amit az XPS és mikroszkópos vizsgálat is igazol (15b. ábra). Itt a $137 \pm 5 \mathrm{~nm}$ vastag réteg 2 - 3 nm vékony amorf szénnel elválasztott 4 - 10 nm szélességü TiC nanokristályokat tartalmaz. A SAED eredményeit a „ProcessDiffraction” számítógépes program segítségével elemeztem, mely a polikristályos vagy amorf minták elektrondiffrakciós analízisének feldolgozására alkalmas [118][119][120][121]. A 15b és c. ábrán látható diffrakciók alapján, az fcc TiC nanokristályok jelenléte, valamint egy kis $<111>$ textúra feltételezhető. 47 at\% Ti tartalomnál (15c. ábra) a $180 \pm 12 \mathrm{~nm}$ vastag réteget teljes egészében keresztülnövő oszlopok $1-2 \mathrm{~nm}$ amorf szénnel elválasztott, 10 - 26 nm átmérőjü TiC kristályokból állnak. Ennél az XPS spektrumnál már a karbid fázis dominál, ellentétben a 6 at\% titánt tartalmazó réteg spektrumával (15a. ábra), ahol az amorf fázis mutatható ki. 

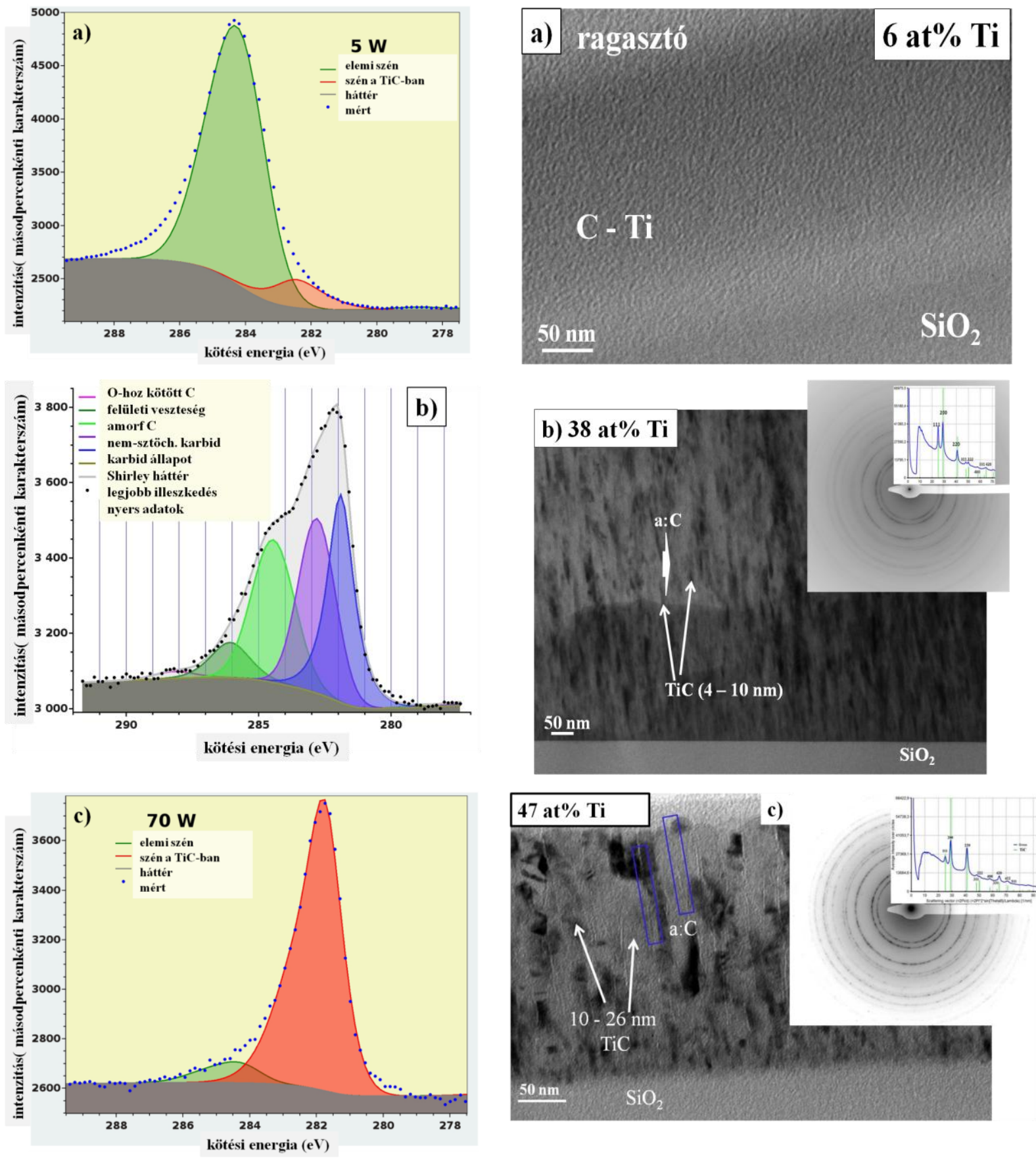

15. ábra: A 6 (a), 38 (b) és 47 at \% (c) Ti tartalmú TiC/a:C nanokompozit vékonyrétegek XTEM képei, XPS spektrumai és SAED (beillesztés) felvételei. A b) és c) képen az fcc TiC nanokristályok elektrondiffrakciója 111, 200, 220, 311, 222, 400 és 331 indexekkel látható.

Az 1. táblázatban bemutatott rétegek közül az 5 és $70 \mathrm{~W}$ közötti Ti teljesítménnyel készült bevonatok elemi összetételét az XPS módszeren kívül energiadiszperzív röntgenspektroszkópiával (EDS) is megvizsgáltam. Az XPS és EDS által adott összetétel vizsgálatok eredményeinek összehasonlítását a 16. ábra mutatja be. 

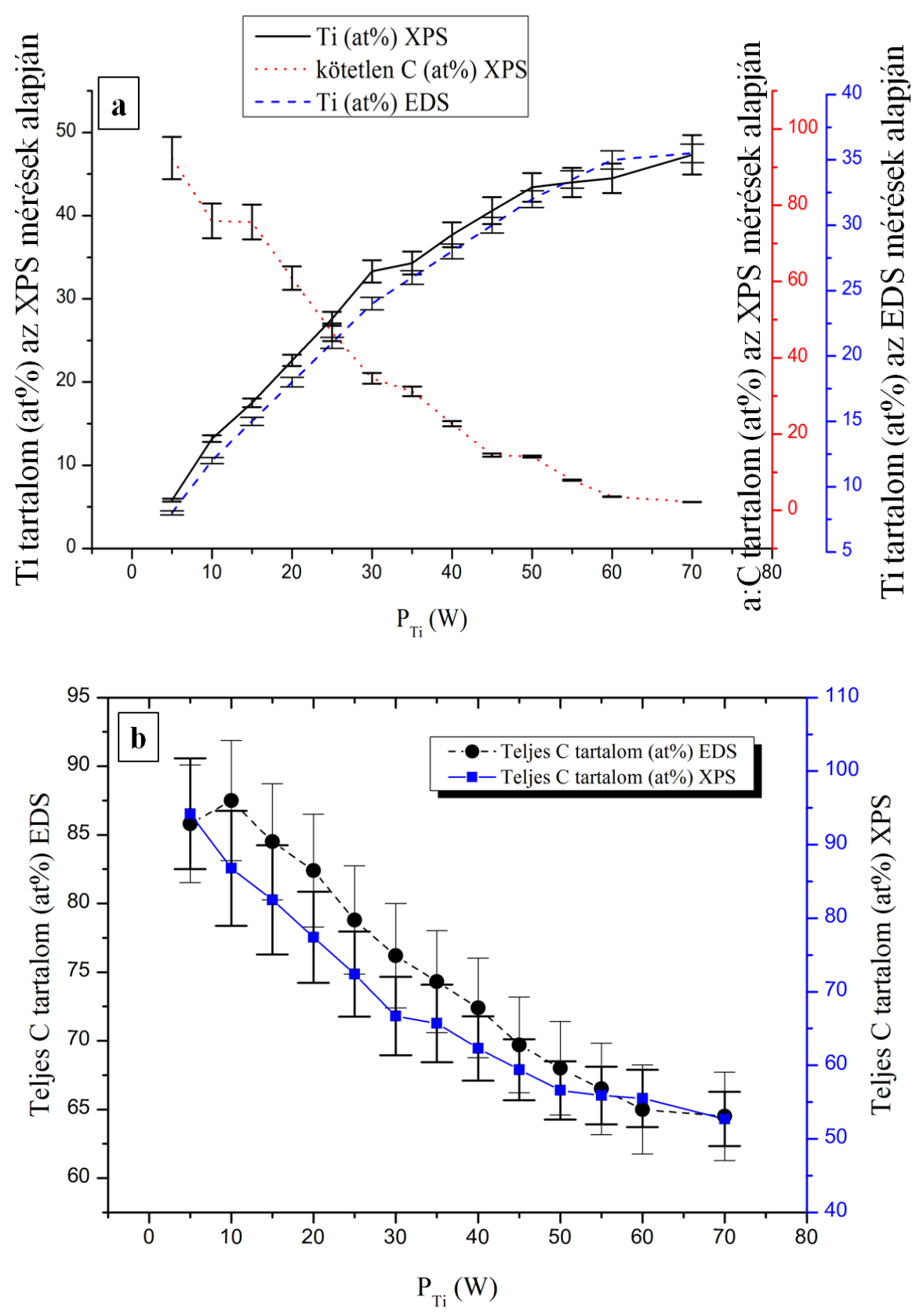

16. a) ábra: A TiC/a:C vékonyrétegek különböző módszerekkel (EDS és XPS) mért Ti éS kötetlen (amorf) C tartalma a Ti céltárgy teljesítményének függvényében. b) Az XPS és EDS által mért teljes C tartalmak összehasonlitása a Ti céltárgy porlasztási teljesítményének függvényében.

Az a:C és a karbid fázisok arányának ellentétes változását a TEM analízis következtetéseihez hasonlóan (15. ábra) az XPS és az EDS eredmények is igazolják (16a. ábra). Az EDS és XPS mérések által meghatározott TiC/a:C vékonyrétegek Ti tartalmát és a nem kötött (= amorf) $\mathrm{C}$ tartalmát a Ti céltárgy teljesítményének függvényében a 16a. ábrán 
foglaltam össze. A 16b. ábrán látható szintén a Ti céltárgy teljesítményének függvényében, az XPS és EDS által meghatározott teljes $C$ mennyiség.

Megállapítható, hogy 47 at\% Ti tartalomig az XPS, EDS és TEM eredményei jó egyezést mutatnak a jól ismert egyensúlyi makroszkopikus Ti - C fázisdiagrammal (17. ábra). Nevezetesen, még a legalacsonyabb teljes $\mathrm{C}$ koncentráció $(52,7 \pm 7$ at\% XPS-sel és $64,5 \pm 5$ at\% EDS-sel) és legmagasabb Ti koncentráció mellett (47,3 \pm 5 at $\%$ XPS-sel és 35,5 \pm 2 at\% EDS-sel) sem mutatható ki egyéb fázis, mint TiC. A szén mindvégig amorf $\mathrm{C}$ formájában van jelen, nem grafitizálódik. Az XPS és az EDS eredmények közötti különbség a C elemzés nehézségeivel magyarázható. Mindkét mérés $\mathrm{C}$ felhalmozódást okozhat.

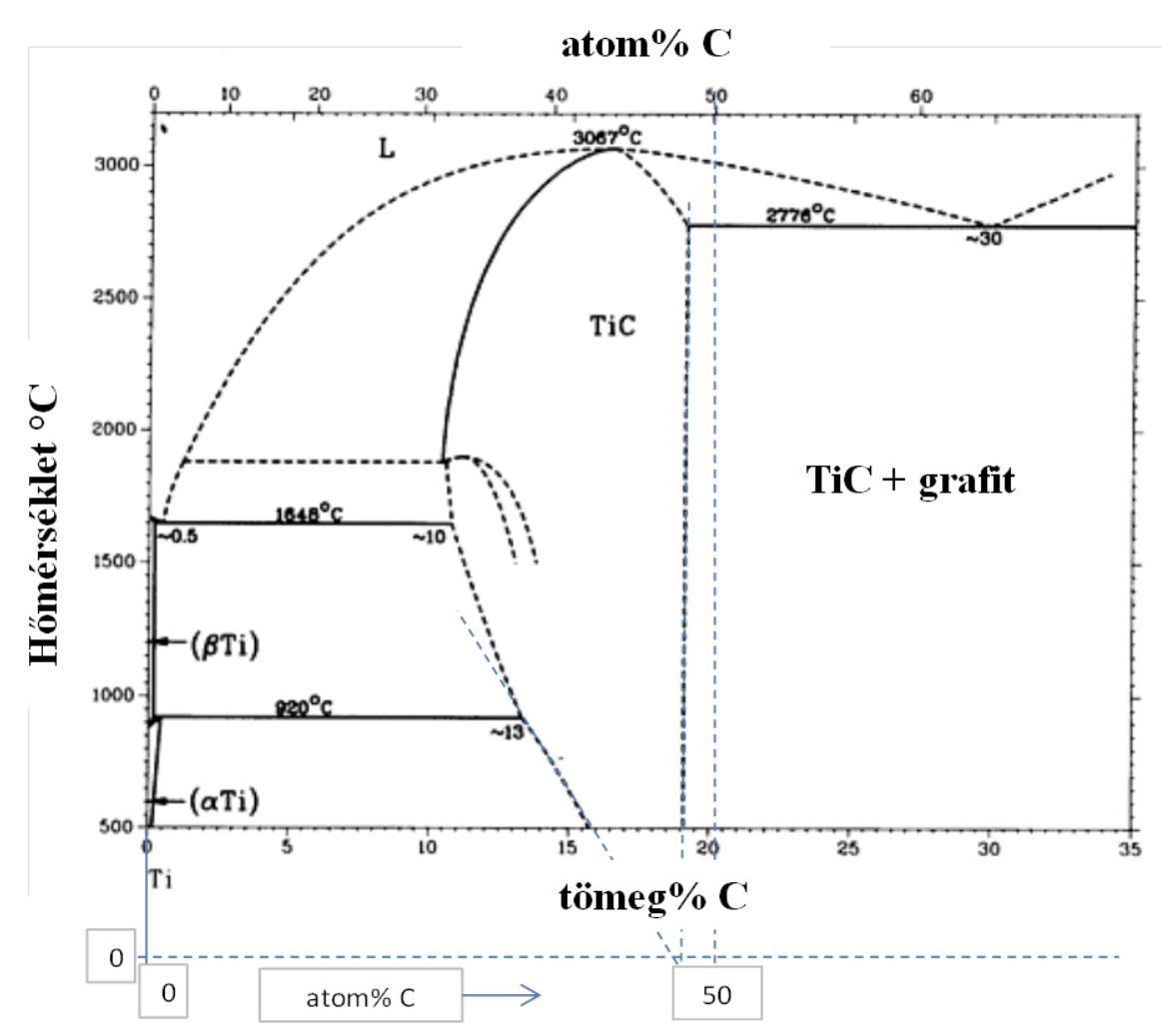

17. ábra: A makroszkopikus Ti-C rendszer egyensúlyi fázisdiagramja [122] a TiC fázis $0^{\circ} \mathrm{C}$-ra kiterjesztett szolvusz vonalaival.

\subsection{Határfelületi energiák vizsgálata}

Az előző fejezetben említett $\mathrm{C} / \mathrm{Ti} / \mathrm{C} / \mathrm{Ti} / \mathrm{C} / \mathrm{Ti}$ multiréteg mellett, a méréseim során használt $\mathrm{Ti}$ és $\mathrm{C}$ céltárgyak sűrüségének megállapítására további porlasztást végeztem $\mathrm{C}$ esetében $150 \mathrm{~W}$ teljesítménynél 10140 másodpercig, valamint Ti porlasztást $100 \mathrm{~W}$ Ti teljesítménynél 3000 másodperces porlasztási idővel. Így összesen mind a Ti, mind a C 
esetében négy különböző porlasztási időt használtam. A létrejött $\mathrm{Ti}$ és $\mathrm{C}$ rétegek vastagságának mérésére AFM és TEM méréseket használtunk, melynek eredményei a 18a. és 18b. ábrán láthatóak.
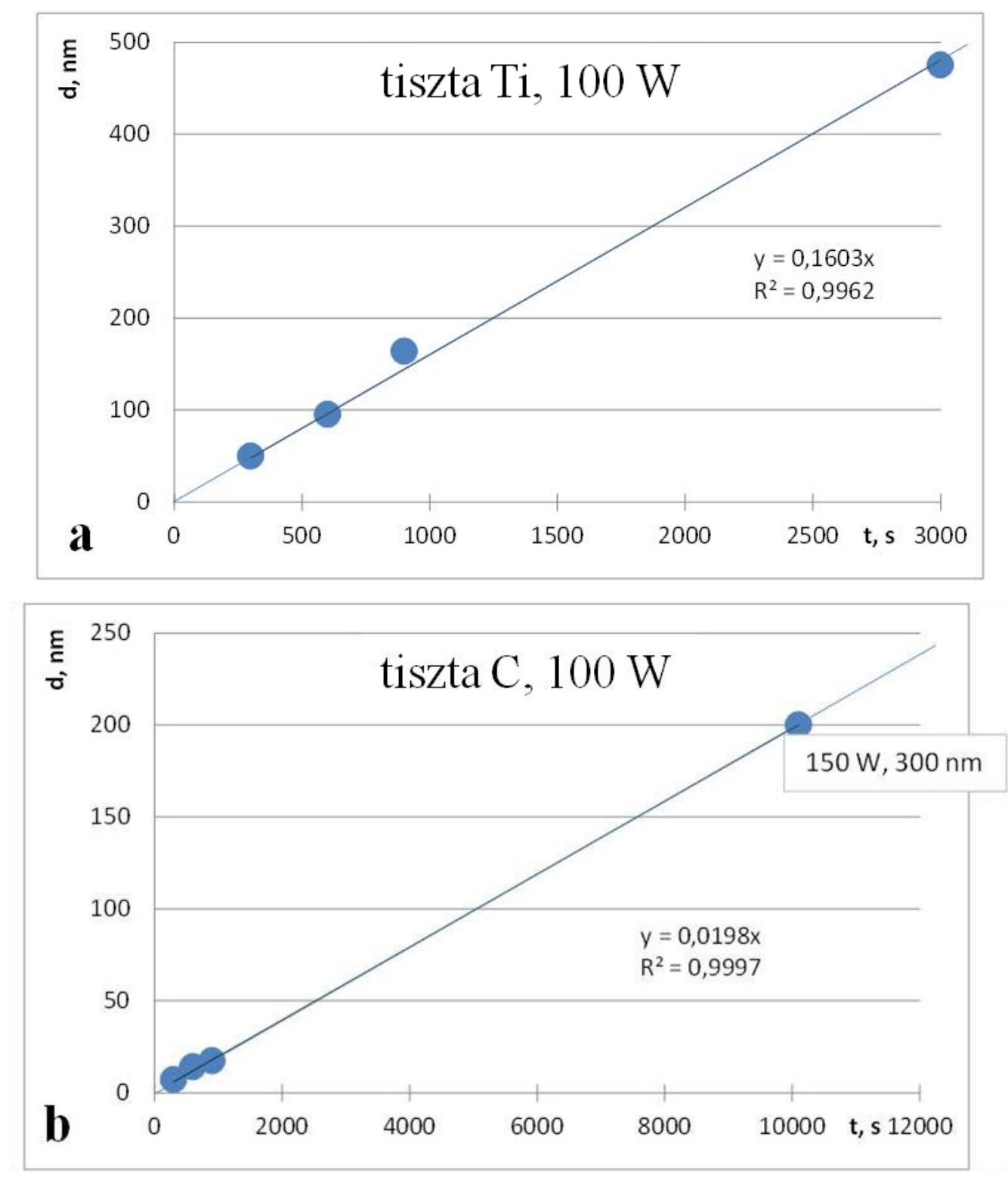

18. ábra: A tiszta Ti réteg (a) és a tiszta szénréteg (b) vastagsága a porlasztási idők függvényében, 100 W-os rögzített porlasztási teljesítmény mellett (kivéve a jobb oldali pontot a (b) ábrán 150 W-nál; az eredetileg mért értéket (kb. 300 nm) 1,5-ös együtthatóval csökkentettük, hogy megfeleljen az ábra egyéb adatpontjainak.

A 18b. ábra utolsó adatpontját a $150 \mathrm{~W}$-ig kibővített teljesítménnyel kaptuk meg, és a kapott vastagságot (kb. $300 \mathrm{~nm}$ ) 1,5-ös együtthatóval csökkentettük, hogy összehasonlítható legyen az ábra többi adatpontjával. Látható, hogy ily módon a 18b. ábra 4 adatpontja (és az 
5. 0;0 adatpont) ugyanazon egyenes vonal mentén jelenik meg. Ez azt jelzi, hogy a kialakult réteg vastagsága arányos a porlasztási teljesítménnyel. Amint azt a 18a. és 18b. ábra bizonyítja, a leválasztott vastagság a porlasztási idővel is arányos. A mérések eredményeit az alábbi egyenletek foglalják össze:

$$
\begin{array}{r}
d_{T i}^{i d}=k_{T i} \cdot P_{T i} \cdot t_{T i} \\
d_{C}^{i d}=k_{C} \cdot P_{C} \cdot t_{C}
\end{array}
$$

ahol $d_{T i}^{i d}(\mathrm{~nm})$ és $d_{C}^{i d}(\mathrm{~nm})$ a tiszta Ti és C leválasztott vastagságai ideális esetben (amikor a két komponens nem zavarja egymás porlódását). $P_{T i}(\mathrm{~W})$ és $P_{C}(\mathrm{~W})$ a Ti és $\mathrm{C}$ céltárgyak porlasztási teljesítményei, $t_{T i}(\mathrm{~s})$ és $t_{C}(\mathrm{~s})$ a Ti-ra és C-re vonatkozó porlódási idők, $k_{T i}$ $(\mathrm{nm} / \mathrm{J})$ és $k_{C}(\mathrm{~nm} / \mathrm{J})$ a Ti és C porlasztási együtthatói szintén ideális esetben. Ez utóbbi együtthatók a 18a. és 18b. ábrán látható regressziós egyenesek meredekségeiből származnak:

$$
k_{T i}=1,60 \pm 0,02 \mathrm{~nm} / \mathrm{kJ}, k_{C}=0,198 \pm 0,002 \mathrm{~nm} / \mathrm{kJ} .
$$

A sürüségértékeket a vastagság, valamint a hordozók réteg nélküli és réteggel fedett súlyméréseinek adataiból számoltam ki. A porlasztási idő növekedésével (lásd a 18a. és 18b. ábra utolsó adatpontjait) a hordozók tömegének növekedését mértük. Ebből, valamint a leválasztott réteg mért vastagságából, a rétegek sürüsége a következő volt: $\rho_{T i}=4,1 \pm 0,4$ $\mathrm{g} / \mathrm{cm}^{3}$ és $\rho_{C}=2,0 \pm 0,2 \mathrm{~g} / \mathrm{cm}^{3}$. Ezen értékek esetében azonban figyelembe kell vennünk mind az analitikai mérleggel végzett tömeg méréséből származó hiba faktorokat, az AFM mérés hibáját, mind pedig a tolómérővel számolt szélesség és hosszúság értékek esetleges pontatlanságát. Ha mindezeket a faktorokat figyelembe vesszük, megállapíthatjuk, hogy a mért sürüség értékek hibahatáron belül megegyeznek a tömbi anyagra jellemző sürüség értékekkel: $\rho_{T i}=4,5 \mathrm{~g} / \mathrm{cm}^{3}$ és $\rho_{C}=1,8-2,1 \mathrm{~g} / \mathrm{cm}^{3}$ [123]. Ezen elemek moláris tömegét $(47,9$ $\mathrm{g} / \mathrm{mol} \mathrm{Ti}$ és $12,0 \mathrm{~g} / \mathrm{mol} \mathrm{C}$ esetében) osztva a fentiekben megadott sürüséggel, a moláris térfogatok a következőknek adódnak: $V_{T i}=11,7 \pm 0,4 \mathrm{~cm}^{3} / \mathrm{mol}, V_{C}=6,0 \pm 0,2 \mathrm{~cm}^{3} / \mathrm{mol}$. Az (1a) és (1b) egyenletet a kapott moláris térfogati értékekkel elosztva adódik a kialakult rétegek mennyisége a hordozók egységnyi felületére vonatkoztatva:

$$
\begin{gathered}
\frac{n_{T i}^{i d}}{A}=z_{T i} \cdot P_{T i} \cdot t_{T i} \\
\frac{n_{C}^{i d}}{A}=z_{C} \cdot P_{C} \cdot t_{C}
\end{gathered}
$$


ahol $n_{T i}^{i d}$ és $n_{C}^{i d}(\mathrm{~mol})$ a leválasztott Ti és $\mathrm{C}$ mennyisége ideális esetben, $A\left(\mathrm{~m}^{2}\right)$ a hordozó felülete, $z_{T i} \equiv \frac{k_{T i}}{V_{T i}}\left(\mathrm{~mol} / \mathrm{m}^{2} \mathrm{~J}\right)$ és $z_{C} \equiv \frac{k_{C}}{V_{C}}\left(\mathrm{~mol} / \mathrm{m}^{2} \mathrm{~J}\right)$ a Ti és a C egyéni porlasztási együtthatói. A fenti értékekből és definíciókból: $z_{T i}=(1,37 \pm 0,03) \cdot 10^{-7} \mathrm{~mol} / \mathrm{m}^{2} \mathrm{~J}$ és $z_{C}=(3,30 \pm$ $0,03) \cdot 10^{-8} \mathrm{~mol} / \mathrm{m}^{2} \mathrm{~J}$.

A Ti - C együttes porlasztásával épülő rétegeket azonban tiszta Ti és tiszta $\mathrm{C}$ céltárgyak ugyanolyan porlasztási idők melletti alkalmazásával kaptuk, amikor ugyanazon hordozóra két komponens egyidejü leválasztása történt. Ideális esetben, amikor a két komponens nem befolyásolja egymást a növekedés során, a Ti móltörtje a kialakult rétegben a következőképpen határozható meg:

$$
x_{T i}^{i d} \equiv \frac{n_{T i}^{i d}}{n_{T i}^{i d}+n_{C}^{i d}}
$$

Behelyettesítve a (2a) és (2b) egyenletet a (3a) egyenletbe $t_{T i}=t_{C}$ esetén, a következő egyenletet kapjuk:

$$
x_{T i}^{i d}=\frac{z_{T i} \cdot P_{T i}}{z_{T i} \cdot P_{T i}+z_{C} \cdot P_{C}}
$$

A fenti együtthatókat $\left(z_{T i}=(1,37 \pm 0,03) \cdot 10^{-7} \mathrm{~mol} / \mathrm{m}^{2} \mathrm{~J}\right.$ és $z_{C}=(3,30 \pm 0,03) \cdot$ $\left.10^{-8} \mathrm{~mol} / \mathrm{m}^{2} \mathrm{~J}\right)$, valamint a $\mathrm{P}_{\mathrm{C}}=150 \mathrm{~W}$ állandó értékét a $(\mathbf{3 b})$ egyenletbe helyettesítve:

$$
x_{T i}^{i d}=\frac{P_{T i}}{36,1 W+P_{T i}}
$$

A 11. ábrából származó különböző mért összetétel értékeket a 19. ábrán $x_{T i}^{i d}$ függvényében, a (3c) egyenletből számítva ábrázoltam. 


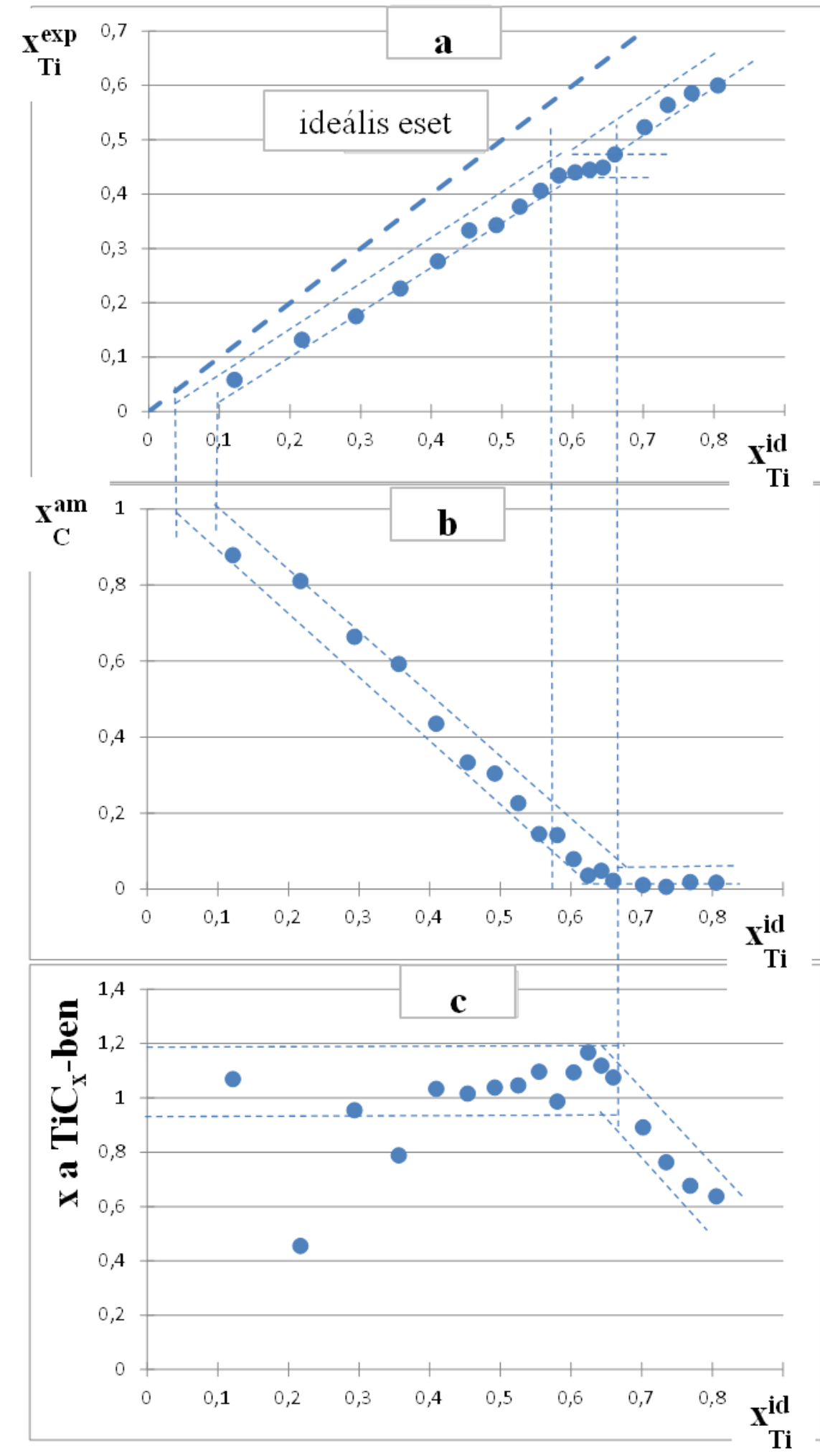

19. ábra: A leválasztott rétegben mért Ti móltörtje (a), a leválasztott rétegben mért amorf C móltörtje (b) és a 3c egyenlet által számított TiC $C_{x}$-ben, az $x$ (c) mért értéke a kialakult rétegben lévö Ti ideális móltörtjének függvényében (a mért értékek a 11. ábráról származnak). A szaggatott vonal az ideális vonalat mutatta (a) és keresztezi a nullát. 
A 19a. ábra szerint, a ténylegesen mért Ti tartalom lényegesen kisebb a leválasztott rétegben, mint az a (3c) egyenletből következik. Ha az egyenest a 19a. ábrán látható első 10 mért ponton keresztül húzzuk, ez az egyenes az $x_{T i}^{\text {exp }}=0$ tengelyt nem az $x_{T i}^{i d}=0$ pontban metszi, mint ahogy azt várnánk, inkább $x_{T i}^{i d}=0,05-n e ́ l$. Ez a következő mechanizmusokkal magyarázható:

i. Ti és $\mathrm{C}$ párhuzamos porlasztásánál az első épülő fázis amorf szén. Ez azért van, mert sokkal kisebb felületi energiával $\left(0,15 \mathrm{~J} / \mathrm{m}^{2}\right)$ [124] rendelkezik a Ti $\left(2,57 \mathrm{~J} / \mathrm{m}^{2}\right)$ [125] valamint a TiC $\left(2,37 \mathrm{~J} / \mathrm{m}^{2}\right)$ [126] felületi energiáihoz viszonyítva. Így, az amorf szén magképződésének energetikai gátja több mint 1000-szer kisebb, mint Ti vagy TiC esetében.

ii. mivel a Ti atomok moláris térfogata (atomi mérete) körülbelül kétszerese az amorf szénének, ezért a Ti atomok szétszóródtak az amorf szénmátrixban anélkül, hogy karbid fázist alakítottak volna ki.

iii. a:C jelenlétében Ti atomok választódnak le a gázfázisból TiC formájában. Ennek a nukleációs folyamatnak Ti atom túltelítettségre van szüksége a gázfázisban.

A fenti következtetések szintén jó egyezést mutatnak a 19b. ábra első 10 mérési pontján átvezetett egyenese mentén. Itt az egyenes szintén nem $x_{T i}^{i d}=0$ pontban metszi az $x_{C}^{a m}=1$ értéket (az amorf szén móltörtje a leválasztott rétegben), hanem ugyanabban az $x_{T i}^{i d}=0,05$ pontban, mint a 19a. ábrán. A (3c) egyenlet alapján, ez az érték a $\mathrm{P}_{\mathrm{Ti}}=2,1 \mathrm{~W}-$ nak felel meg. Amikor tehát C-et és Ti-t egyidejüleg porlasztok $\mathrm{P}_{\mathrm{C}}=150 \mathrm{~W}$-nál, $\mathrm{P}_{\mathrm{Ti}} \leq 2,1 \mathrm{~W}$ nál tiszta amorf szén fog leválni. $\mathrm{P}_{\mathrm{Ti}}>2,1 \mathrm{~W}$ esetén azonban lehetségessé válik a TiC fázis magképződése és TiC szemcsék mechanikai keveréke alakul ki az a:C mátrixban.

Ahogyan a 19a. ábrából következik, a közép $x_{T i}^{i d}$ értékeknél a kísérleti pontok majdnem ugyanolyan meredekséggel nőnek, mint az ideális rétegnövekedésből elvárható. Így a TiC fázisnövekedés az amorf szén mátrixon belül nem gátolt a $0,05 \leq x_{T i}^{i d} \leq 0,57$ tartományban, mely megfelel a $2,1 \leq P_{T i} \leq 54 \mathrm{~W}$-nak $\mathrm{P}_{\mathrm{C}}=150 \mathrm{~W}$-nál.

Amikor az $x_{T i}^{i d}$ értéke meghaladja a 0,57-et (megfelel a $\mathrm{P}_{\mathrm{Ti}}=54 \mathrm{~W}$-nak $\mathrm{P}_{\mathrm{C}}=150 \mathrm{~W}$ nál), a további Ti porlódás új kinetikus gátja jön létre. Ez, a további Ti növekedés szinte teljes megállásában nyilvánul meg a 19a. ábrán ábrázolt $x_{T i}^{\text {exp }}$-ben a $0,57 \leq x_{T i}^{i d} \leq 0,63$ intervallum esetén $\left(54 \leq P_{T i} \leq 70 \mathrm{~W} ; \mathrm{P}_{\mathrm{C}}=150 \mathrm{~W}\right)$. Ennek az az oka, hogy ha további Ti porlódna, az amorf szén mennyisége nullává válna ebben a tartományban, mivel a fennmaradó amorf szén beépülhetne a TiC fázisba. Azonban, ahogyan a 19b. ábrából 
következik, ez nem történik meg: az amorf szén móltörtje alacsony, de pozitív értékekkel stabilizálódik (11. 12. és 19b. ábra).

Összességében elmondható, hogy a 47 at\% Ti tartalmú rétegek esetében még nincs jelen elegendő titán ahhoz, hogy megkösse az összes szénmennyiséget, így e réteg esetében még található amorf szén a $\mathrm{TiC}$ kristályok között (12. ábra). Ez feltehetően a TiC nanokristályok amorf szén általi határfelületi stabilizálásának következménye. Ha ez az amorf réteg eltünik (kb. 50 at\% feletti Ti tartalomnál; 14. ábra), a TiC nagy $-2,37 \mathrm{~J} / \mathrm{m}^{2}$ felületi energiájából fakadóan, nagy energiájú TiC / TiC szemcsehatárok alakulnak ki. Ha két ilyen növekvő TiC kristály egy közös határfelületen találkozik, azok várhatóan nagy energiájú, nagyszögü szemcsehatárt fognak alkotni és beindul az orientációtól függő versengő növekedés (13. ábra; zónamodell 5. része). Amíg azonban az alacsony határfelületi - 0,15 J/m² - energiával rendelkező amorf szén választja el a TiC nanokristályokat növekedésük gátolt, és az így létrejövő határfelületi energia sokkal alacsonyabb lesz. Ezért, a vékony a:C réteggel elválasztott $\mathrm{TiC}$ nanokristályok teljes energiája kisebb lesz, mint ugyanaz lenne vékony amorf szén réteg nélkül [127].

Egy további lehetőség arra, hogy a leválasztott Ti atomok megtartsák a vékony amorf réteget a TiC kristályok között a TiC fázis széntartalmának csökkentése, vagyis az oldhatósági intervallumának növekedése lenne. Amint az a 19c. ábrából következik, ez történik $70 \mathrm{~W}$ Ti teljesítménytől kezdődően. A TiC széntartalma a létrejött nanoméretü rétegben jóval kisebb lesz, mint az a 17. ábrán látható makroszkopikus fázisdiagramból következne. Nagyon fontos megjegyezni, hogy hcp-Ti fázis még akkor sem alakul ki, amikor az ideális Ti tartalom 80 at\%-ra, míg a mért Ti tartalom 60 at\% -ra emelkedik, annak ellenére, hogy a makroszkopikus fázisdiagram (17. ábra) alapján ezt várnánk. Ez azt jelenti, hogy az általam készített Ti - C nanorétegek fázisképződése 47 at\% Ti tartalom felett nem követi a makroszkopikus fázisdiagramot, sem az ideális esetre vonatkozó (3c) egyenletet.

Bizonyítottam, hogy 2 vagy több elem egyidejű porlasztásával, a porlasztott réteg összetétele nem határozható meg kizárólag a komponensek porlasztási teljesítményeinek arányából. A különbözö fázisok (a:C, köbös TiC, hcp-Ti) különbözö határfelületi energiái és különböző magképző gátjai nagymértékben befolyásolják a nanoréteg fázisszerkezetét és mikrostruktúráját, ami sem a 18. ábra kalibrációs görbéiből, sem a 17. ábra makroszkopikus fázisdiagramjából nem megjósolható. A kialakult nanokompozit vékonyrétegek összetételénél és szerkezeténél a határfelületi energiákat, nukleációs korlátokat és a különböző fázisokra jellemző nano-termodinamikát, mint befolyásoló tényezőket is figyelembe kell venni. 


\subsection{A rétegek fázisösszetételének jellemzése}

A TiC/a:C vékonyrétegek különböző hullámhosszúságú lézerrel készült Raman spektrumai a 20. ábrán láthatóak. A 17,5, 23, 33, 38 és 43 at\% Ti tartalmú minták Raman spektrumait egy $785 \mathrm{~nm}$ hullámhosszú diódalézer gerjesztő fényforrás, míg a 6, 28, 33, 44, 47, 52, 56, 58,5 és 60 at\% Ti tartalmú minták spektrumait egy 488 nm-en müködő Ar-ion gázlézer gerjesztő fényforrás mellett vettük fel.

A Raman spektrumok összehasonlítása alapján elmondható, hogy 6 at\% $\mathrm{Ti}$ tartalomnál (20a. ábra) csak az amorf szénre jellemző, $1000-1600 \mathrm{~cm}^{-1}$ közötti széles sáv figyelhető meg a mintában. Ebben a tartományban két széles sáv látható $1420 \mathrm{~cm}^{-1}$ és 1530 $\mathrm{cm}^{-1}$ körüli maximumokkal, melyek az amorf szén D (rendezetlen) és G (grafitos) sávjaival azonosíthatóak. A nagyobb frekvenciasávot $\left(\sim 1530 \mathrm{~cm}^{-1}\right)$ és az alsó frekvenciasávot $(\sim 1420$ $\mathrm{cm}^{-1}$ ) általában $\mathrm{G}$ és $\mathrm{D}$ sávokként azonosítják a különböző szénanyagokra, melyek pontos értéke a szén mennyiségétől és formájától függően más és más lehet, azonban a sávpozíciókban jelentős eltolódás nincs. Karekin és mtsai [128] kutatásában az $1590 \mathrm{~cm}^{-1}$ és $1350 \mathrm{~cm}^{-1}$ közötti intenzitáscsúcsok kapcsolódnak a rendezetlen grafit G és D sávjához, míg Viana [129] és mtsai a gyürüs vagy láncos szerkezetekben elhelyezkedő, C sp ${ }^{2}$ helyeket tartalmazó széntartalmú anyagokra körülbelül G $1582 \mathrm{~cm}^{-1}$ és D $1350 \mathrm{~cm}^{-1}$ frekvenciaértékeket állapítottak meg. A D sáv az amorf szén alapú anyagok hosszú távú rendjének hiánya miatt válik Raman aktívvá, míg a $\mathrm{G}$ sáv a $\mathrm{C} \mathrm{sp}^{2}$ vibrációhoz rendelhető, amely az anyag rendezettebbé válása révén szélesíti és eltolja a frekvenciát [130]. Han Wu és mtsai több D $(1392 ; 1389 ; 1379 ; 1388 ; 1375 ; 1398 ; 1395 ; 1383 ; 1406 ; 1417 ; 1333)$ és G $(1550 ; 1552 ; 1548 ; 1535 ; 1547 ; 1546 ; 1524)$ értéket is megállapítottak DLC (gyémántszerü szén) rétegekre vonatkozóan [131], melyek szintén bizonyítják, hogy a sávpozíciókban jelentős eltolódás nincs. A porlasztási teljesítmény növekedésével a spektrum alakja ebben a tartományban (D és $\mathrm{G}$ ) jelentősen megváltozik. A széles sávok lekeskenyednek, ami a szerkezet rendezettségének növekedésére utal, míg a $G$ sáv nagyobb hullámszámok felé tolódása a grafitos jelleg növekedését mutatja. 


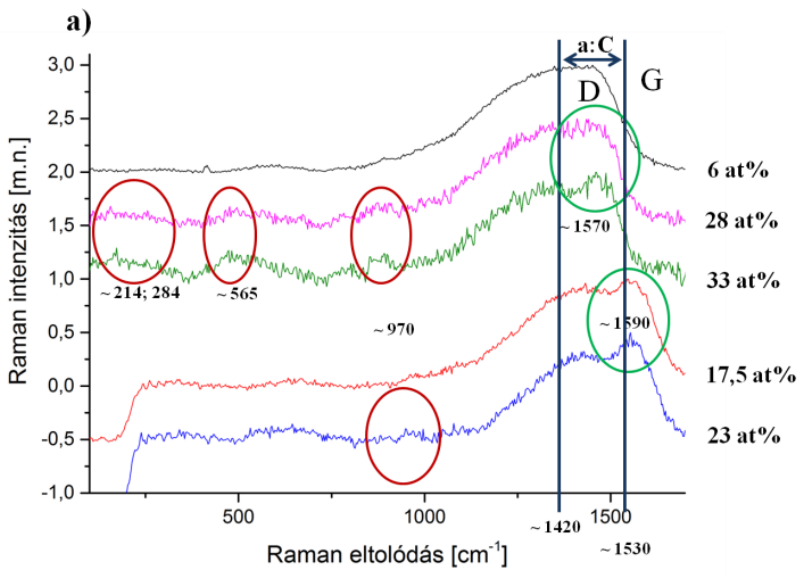

b)
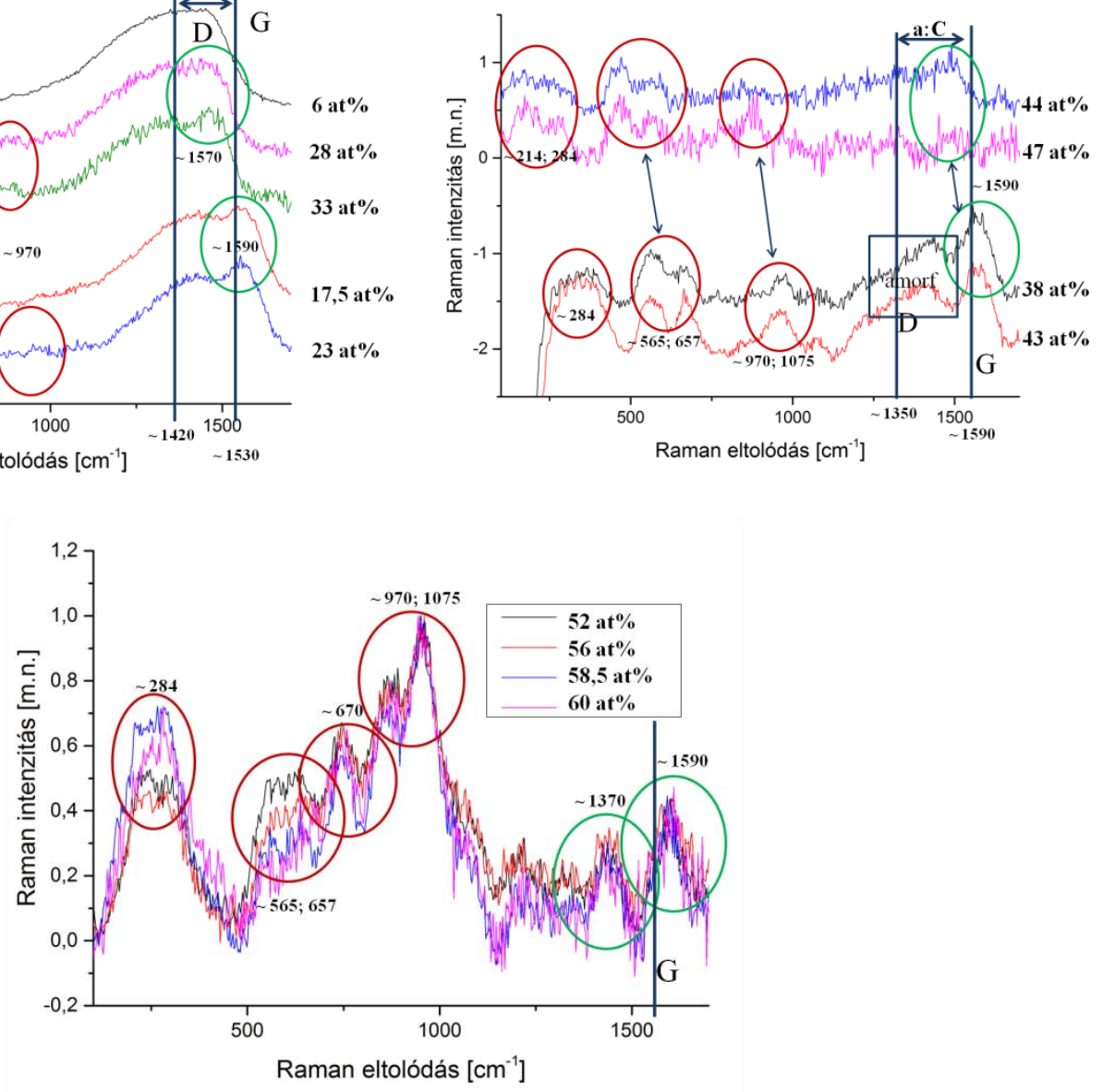

20. ábra: A TiC/a:C vékonyrétegek különböző Ti tartalomnál a) 6 - 33 at\%, b) 38 47 at\%) és c) 52 - 60 at\% készült Raman spektrumai. A spektrumokon azonosíthatóak a körökkel jelölt nanokristályos TiC fázis vonalai és a vonallal, téglalappal kijelölt amorf C (D és $G$ vonalak) sávok. A számok az adott TiC csúcsra, valamint az amorf szénre jellemzö frekvenciaértékeket jelölik, míg a jel a frekvenciaértékek körülbelüli értékét érzékelteti.

A 17,5 és 23 at\% titánt tartalmazó mintában (20a. ábra) az amorf szén széles sávját alkotó csúcsok kezdenek szétválni és $\sim 1590 \mathrm{~cm}^{-1}$ körül, de 23 at\% esetében $\sim 970 \mathrm{~cm}^{-1}$-nél is kis intenzitású, széles sávok jelennek meg, melyek valamilyen rendezetlen TiC fázishoz rendelhetőek. A $28(25 \mathrm{~W})$ és 33 at\%-os mintában (20a. ábra) az amorf szén csúcsainak szétválása még jelentősebb és $200-450 \mathrm{~cm}^{-1}, 500-750 \mathrm{~cm}^{-1}$ között, valamint $1000 \mathrm{~cm}^{-1}$ körül újabb kis intenzitású, széles sávok jelennek meg, melyek a 214, 284, 565, 970 és $\sim 1590 \mathrm{~cm}^{-1}$ frekvenciáknál lévő rendezetlen TiC fázisokhoz rendelhetők [132][133][134]. Hasonló eredmények találhatók Kumar és mtsai [31] munkájában, ahol az alacsony Ti porlasztási teljesítménynél ( $25 \mathrm{~W}$ ) készült mintában megjelenő TiC csúcsok 221, 321, 527 és $706 \mathrm{~cm}^{-1}$ rezgési módjai a hipo-sztöchiometrikus $\mathrm{TiC}_{1-\mathrm{x}}$ megfelelői. A 33 at\%-os minta 
esetében (20a. ábra), az $1570 \mathrm{~cm}^{-1}$ alatt megmaradó szélesebb szórási járulék arra utal, hogy a szerkezetben a szénfázist 2 komponens alkotja - az egyik továbbra is rendezetlen szénszerkezet, a másik viszont már rendezettebb és több $\mathrm{sp}^{2}$ gyürüt tartalmazó, grafitosabb szerkezet. A TiC sávok intenzívebbek, ugyanakkor továbbra is szélesek. A 6, 28 és 33 at\%-os minták (20a. ábra) jel/zaj viszonya alapján elmondható hogy az amorf szén szórási járuléka egyre kisebb mértékü, aminek oka lehet a tisztán amorf szén alkotta szerkezeti tartományok mennyiségének csökkenése vagy az $\mathrm{sp}^{3}$ hibridizált szénatomok arányának növekedése a szerkezetben.

A magnetronos porlasztással előállított a:C rétegek Raman spektrumai azt mutatják, hogy az ilyen típusú rétegek jelentős mennyiségü grafitszerü $\mathrm{sp}^{2} \mathrm{C}$ kötést tartalmaznak. Páratlan tagú gyürüket, ívelt grafit lapokat, és $\mathrm{sp}^{3}$ hibridizált $\mathrm{C}$ atomokat is találunk, amelyek gyémántszerű szénszerkezetet képeznek az atomkötési szögek és a kötési hosszak szerkezeti rendezetlenségével [135]. A különböző átmeneti fémek katalitikus hatása a gyémántszerű $\mathrm{sp}^{3}$ szén szerkezet grafitszerű szénbe való átalakulását eredményezheti, amelynek magasabb $\mathrm{sp}^{2}$ tartalma van [136].

A 38 és 43 at\% Ti tartalomnál készült minták (20b. ábra) esetén $\sim 1350 \mathrm{~cm}^{-1}$ körül még mindig látható egy kisebb amorf rész, ám a spektrumokat már a TiC csúcsok uralják 284, 565, 657, 970, 1075 és $\sim 1590 \mathrm{~cm}^{-1}$-nél [132][133][134].

A 44 at\%-os mintában (20b. ábra) az amorf szén csúcsainak intenzitása jelentős mértékben lecsökken, ugyanakkor a korábban megfigyelt, elkülönülö G sáv itt is jelen van, de a nagyobb hullámszámok felé, $1590 \mathrm{~cm}^{-1}$-re tolódott, a szerkezet magasabb szintü grafitizációjára utalva. Ezt támasztja alá a D sáv intenzitásának csökkenése is, vagyis a hibahelyek által aktivált $\mathrm{D}$ csúcs kisebb lesz, ha a nanokristályok mérete megnő. A TiC csoportok elkülönülése megkezdődött, a rendezett TiC szerkezetre utaló sávok az ennél magasabb Ti tartalmú mintákban figyelhetők meg.

A 47 at\%-os mintában (20b. ábra), a 20c. ábrán látható, 52, 56, 58,5 és 60 at\%-nál készült mintákhoz hasonlóan, amorf szén sávok nem figyelhetők meg. A TiC csúcsai dominálják a spektrumot, tiszta szénfázis már nem alakul ki. A 44 és 47 at\% titánt tartalmazó minták esetén (20b. ábra) a beazonosított csúcsok a következők: 214, 284, 565, 657, $\sim 970, \sim 1075$ és $\sim 1590 \mathrm{~cm}^{-1}$, a maradék 4 minta esetében (20c. ábra) pedig $\sim 284, \sim 565, \sim$ 657, $\sim 670, \sim 970, \sim 1075, \sim 1370$ és $\sim 1590 \mathrm{~cm}^{-1}$-t azonosítottunk [132][133][134].

Összességében elmondható, hogy az amorf szén mátrix mennyisége a Ti mennyiségének növelésével csökken, és egy rendezettebb szénszerkezet jelenik meg. Ez a rendezett szénszerkezet TiC formájában mutatkozik meg, vagyis az amorf szén mellett ez az 
egyetlen azonosítható szénfázis, amelyet az XPS (11. ábra), HRTEM (12. ábra) és SAED (14. ábra) felvételek, valamint az elméleti számolások is igazolnak.

Az 565 és $670 \mathrm{~cm}^{-1}$-es csúcsok egyezést mutatnak a hipo-sztöchiometrikus TiC $_{0,67}$ Raman spektrumával [137][132]. A csúcsok minimális eltéréseit a $\mathrm{TiC}_{\mathrm{x}} ; \mathrm{x}=0,47-0,98$ közötti széles sztöchiometria tartománya okozza [53]. Így a továbbiakban a kialakuló fázisok rácsállandóinak koncentráció függvényében történő eltolódását XRD-vel is vizsgáltuk. Az XRD spektrumok a 21. ábrán láthatóak.

Köbös TiC

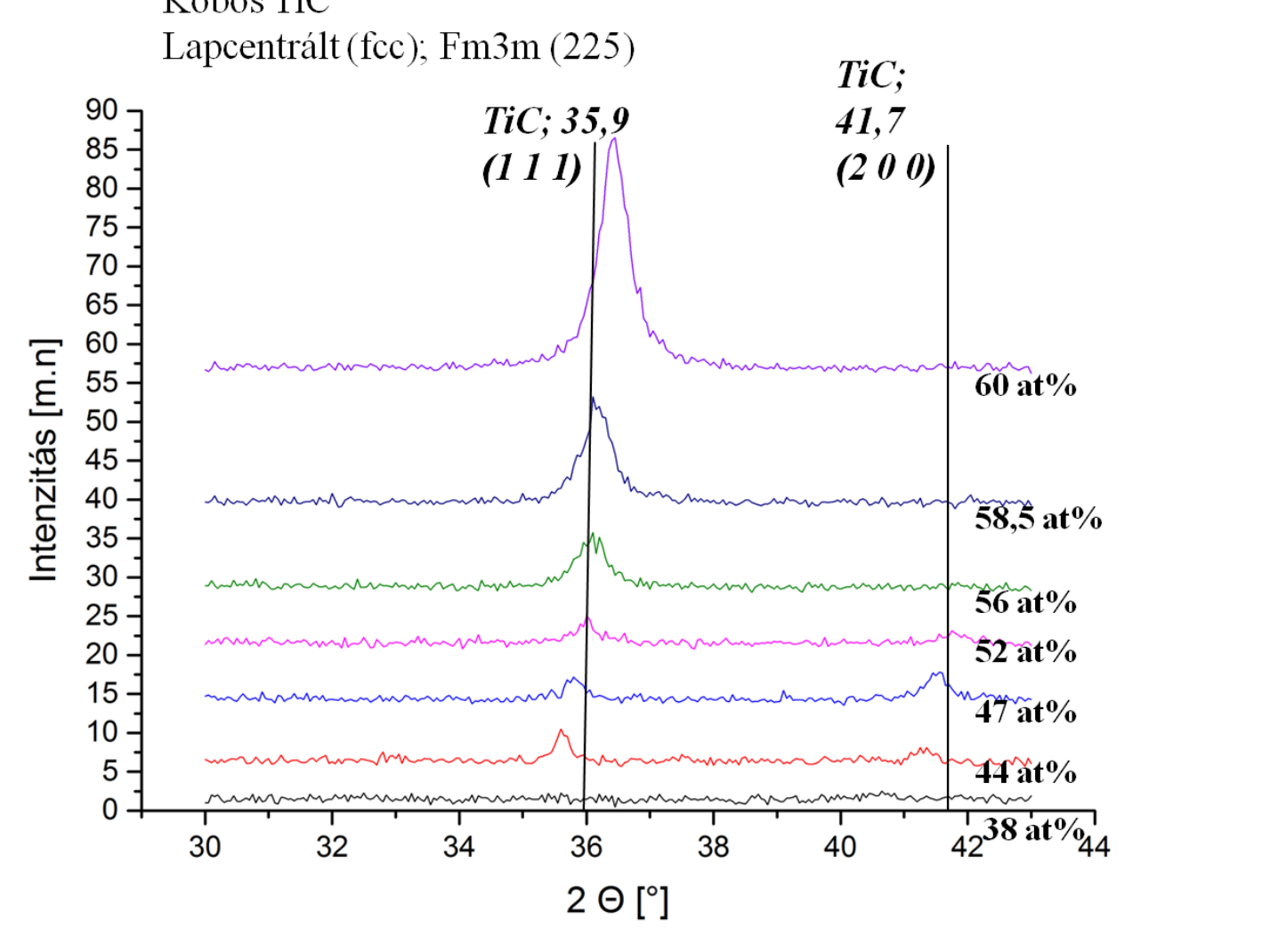

21. XRD diffrakciók a különbözö összetételü mintákról.

Az előző vizsgálatokkal összhangban, a 21. ábrán bemutatott XRD diffraktogramok is alátámasztják, hogy az általam vizsgált rétegekben, még a legmagasabb Ti tartalom esetén is, csak fcc TiC fázis mutatható ki.

- Mivel a 38 at\% Ti tartalomnál kevesebb titánt tartalmazó rétegek még röntgen amorfak, így azok nem kerültek ábrázolásra.

- A 21. ábra azonban jól szemlélteti, hogy a 44 at\%-os minta esetében már megjelenik a TiC mindkét csúcsa balra tolva. 
- A 47 at\%-os mintánál két viszonylag erős csúcs látható a 35,9 és 41,7-es TiC 20ja közelében.

- Az összes minta intenzitás vonalai közül az 52 at\% titánt tartalmazó áll legközelebb a TiC (111)-es csúcsához.

- A 56 - 60 at\%-os minták esetében tapasztalható nagy intenzitás-eltérések az anyag textúráltságával magyarázhatóak. Ezekben a rétegekben a hordozó felületére merőlegesen $<111>$ textúra alakul ki, amit a keresztmetszeti TEM diffrakciók is alátámasztanak (14. és 15. ábra), továbbá a titán többletü TiC rétegekben a reflexiók eltolódnak. Ez a tény a szakirodalomban jól ismert [138][139].

\subsection{TiC/a:C nanokompozit vékonyrétegek mechanikai és tribológiai tulajdonságai}

Munkámban elemeztem a TiC/a:C vékonyrétegek szerkezetének mechanikai tulajdonságokra gyakorolt hatását is. A vizsgálatok kezdetén itt is valamennyi vékonyréteget nagyjából ugyanolyan méretü oxidált szilícium hordozóra porlasztottam. A bevonatok vastagságát 30 és 25 perc közötti porlasztási idővel szabályoztam. Mivel a titán leválasztási sebessége a teljesítmény növelésével megnövekedett, a közel azonos vastagságú rétegek előállítása érdekében csökkentettem az időt. Az így kialakult rétegek vastagsága, a titántartalomtól függően, nagyjából $102 \mathrm{~nm}$ és $180 \mathrm{~nm}$ között változott (1. táblázat).

A TiC/a:C nanokompozit vékonyrétegek mechanikai (keménység $(\mathrm{H})$, rugalmassági modulusz (E)) és tribológiai tulajdonságai erőteljes változatosságot mutattak a Ti tartalom függvényében. A kísérletekből igazoltam, hogy a rétegek vastagsága hatással lehet a nanoindentációs mérésekre. A munkám során vizsgált TiC/a:C rétegek hozzájárulása a mért H és E görbéken azonban mindig azonosítható volt, vagyis a réteg nélküli hordozó (mint referencia) mechanikai tulajdonságai minden esetben megkülönböztethetőek voltak. Ezt szemlélteti a 22. ábra, ahol a hordozó H (a) és E (b) értékei a 38 at\% titánt tartalmazó $\mathrm{TiC} / \mathrm{a}: \mathrm{C}$ réteggel kerültek összehasonlításra. 

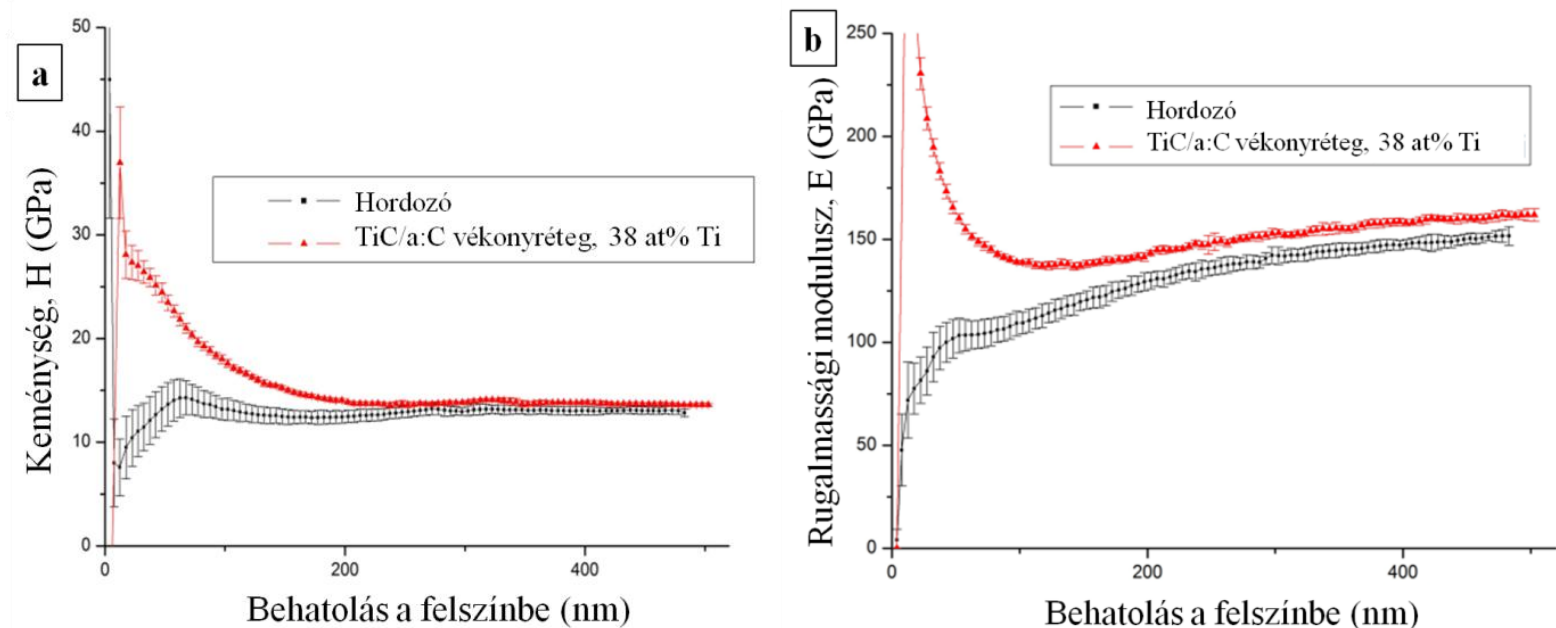

22. ábra: A TiC/a:C vékonyréteg és a $\mathrm{SiO}_{2} / \mathrm{Si}$ (001) hordozó mechanikai tulajdonságai közötti különbségek: a) keménység és b) rugalmassági modulusz a tü benyomódásának függvényében.

A TiC/a:C nanokompozit vékonyrétegek $H$ és $E$ értékeit a titán tartalom függvényében a 23. ábrán mutatom be.

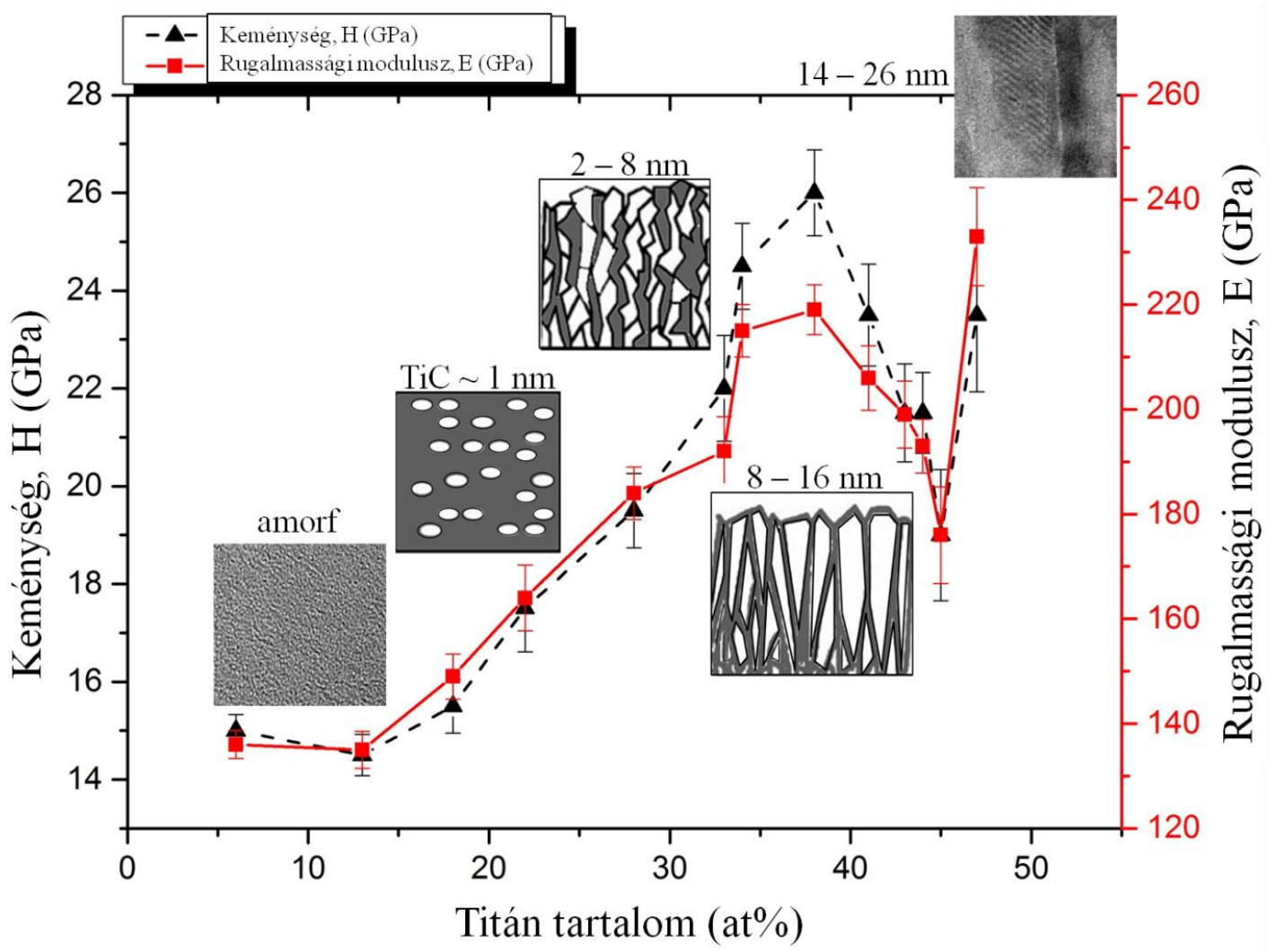

23. ábra: A TiC/a:C vékonyrétegek mechanikai jellemzőinek (H és E) mért értékei a Ti tartalomtól függóen. 
A H és E értékek minimálisak kb. 6 és 17,5 at\% közötti Ti tartalomnál, a teljesen amorf szerkezet következtében. Átlagban 17,5 at\% Ti tartalomnál, a kezdeti kristályosodási állapotnál, a TiC nanokristályok a:C mátrixba ágyazva jelennek meg egy kb. 149 GPa-os E és 15,5 GPa-os H értéket eredményezve. Nedfors és mtsai [140] nanokristályos nióbium-karbid $(\mathrm{NbC}) /$ amorf $\mathrm{C}$ rétegeket vizsgáltak TiC/a:C nanokompozitokkal összehasonlítva. Megállapították, hogy a mechanikai tulajdonságok erősen függenek az a:C mennyiségétől, valamint az amorf mátrixba ágyazott $\mathrm{NbC}$, illetve TiC nanokristályok méretétől. Ök 64 és 43 at\% közötti a:C tartalmú nankompozitokat vizsgáltak, melyek megfelelnek az ábrán látható 17,5 és 28 at\% Ti tartalmú rétegeknek. Az E értékek tekintetében hasonlóan Nedfors és mtsai kutatási eredményéhez [140], a rugalmassági modulusz értékek növekedését láthatjuk a bevonatok amorf széntartalmának csökkenésével nagyjából 149 GPa-ról 184 GPa-ra. Ezt követően, kb. 34 at\% Ti tartalomig a TiC nanokristályok mérete a Ti mennyiség növekedésével növekszik $(2-8 \mathrm{~nm})$, míg az a:C réteg vastagsága csökken $(10-3 \mathrm{~nm})$. Ez továbbra is folyamatosan növekvő 24,5 GPa-os H és 215 GPa-os E értékeket eredményez. A 34 és 41 at\% közötti titán tartalmú keskeny összetétel tartomány biztosítja a maximális keménységi (26 GPa) és rugalmassági modulusz (219 GPa) értékeket. Ebben a szerkezetben a 8 - 16 nm vastagságú TiC szemcsék 2 - 3 nm vékony, amorf mátrixba ágyazódnak. Mechanikai tulajdonságok szempontjából ezek a leginkább megfelelő rétegek. A Ti tartalom további növekedése (41 - 45 at\%) már csökkenő $\mathrm{H}$ és $\mathrm{E}$ értékeket eredményez, ami a következőképpen magyarázható: a szén mennyisége nem elegendő egy teljesen folyamatos a:C mátrix kialakításához, amely a TiC szemcsék közötti határok kialakulásához vezet. Ily módon lehetségessé válik a TiC-TiC szemcsehatárok atomi csúszása. Végül 47 at\% Ti tartalomnál az a:C mennyisége minimálisra csökken és egy 14 - 26 nm szemcseméretü polikristályos TiC réteg alakul ki egy nagyjából 23,5-ös H és 233-as E értéket eredményezve.

Kétfázisú rendszerek esetében, a $10 \mathrm{~nm}$ alatti szemcseméret tartományba eső nanokompozitok az amorf fázis jellegétől függően osztályozhatóak [110]. A polikristályos anyagok mechanikai tulajdonságai ugyanakkor függenek a szemcsemérettől, mely összefüggés a Hall-Petch egyenlettel [141] írható le:

$$
\sigma_{y}=\sigma_{0}+k d^{-1 / 2}
$$

ahol $\sigma_{y}$ a folyáshatár, $\sigma_{0}$ a szemcsehatárok hiányában fellépő súrlódási feszültség, $k$ egy állandó, az ú.n. Hall-Petch meredekség és $d$ a szemcseméret. Ez az összefüggés kimondja, hogy a $0,1 \mu \mathrm{m}$ szemcseméret feletti tartományban a folyáshatár vagy keménység nő, ha a szemcseméret csökken, vagyis a Hall-Petch-szerü hatások egyfázisú polikristályos 
vékonyrétegek esetében érvényesek. A 0,1 $\mu \mathrm{m}$ szemcseméret alatti tartományban azonban, egészen a $10 \mathrm{~nm}$ feletti szemcseméretig számos rendszer esetében, mint a $\mathrm{Cu}$, vagy a $\mathrm{Ni}, k$ értéke csökken vagy negatívvá válik [141]. Ez a jelenség, mely az ábránkon látható $14-26$ nm szemcseméretü polikristályos TiC rétegre is jellemző, az inverz Hall-Petch-hatás (IHPE) néven ismert. Itt a nagyobb szemcseméret következtében csökken a szemcsehatároló atomok frakciója, azaz a H és E értékek ismét növekszenek. Gulbinski és mtsai [142] valamint Zehnder és mtsai [143] ugyanerre a következtetésre jutottak, vagyis a Ti koncentrációjának változtatásával változik - az általuk reaktív magnetronos porlasztással előállított - TiC rétegek keménysége. Esetükben az 50 at\% Ti-t tartalmazó rétegnél tapasztaltak maximális, $25 \mathrm{GPa}$ mikrokeménységet.

A H/E arány bevezetése a rétegekben fellépő meghibásodási mechanizmust jellemzi, míg a $\mathrm{H}^{3} / \mathrm{E}^{2}$ arány a réteg képlékeny alakváltozással szembeni ellenállásáról ad információt. A $\mathrm{H}$ és $\mathrm{E}$ mért értékei ezen kívül meghatározhatják az ilyen típusú bevonatok tribológiai viselkedését [144][145]. Jó kopásállóságú rétegekre utal a H/E =0,1-hez közeli értéke, vagyis a nanokompozitok deformációja elsősorban a $\mathrm{C}$ mátrix rugalmas deformációjából ered [9] [146]. A minél magasabb $\mathrm{H}^{3} / \mathrm{E}^{2}$ arány a képlékeny alakváltozással szembeni növekvő ellenállásra utal [144]. A H/E, $\mathrm{H}^{3} / \mathrm{E}^{2}$ és a súrlódási együttható értékeit $(\mathrm{CoF}, \mu)$ a 24. ábrán foglaltam össze.

A $40 \mathrm{~W}$ Ti porlasztási teljesítménynél (30 at\% Ti EDS-sel) készült réteg rendelkezik a legmagasabb $\mathrm{H}=26 \mathrm{GPa}$ és a legmagasabb $\mathrm{E}=220 \mathrm{GPa}$ értékekkel, ami H/E = 0,12-es és $\mathrm{H}^{3} / \mathrm{E}^{2}=0,4 \mathrm{GPa}-o s$ arányt ad, ahogy az a 24a. ábrán is látható. Az EDS alapján nagyjából 20 at\% Ti összetételnél kapott képlékeny alakváltozással szembeni 0,37 GPa-os ellenállás $\left(\mathrm{H}^{3} / \mathrm{E}^{2}\right)$ értéket összehasonlítottam Sedlácková és mtsai [147], Musil és mtsai [144], valamint Martínez és mtsai [38] eredményeivel. Sedlácková és mtsai $\mathrm{H}^{3} / \mathrm{E}^{2}=0,14 \mathrm{GPa}$-os értéket kaptak $200{ }^{\circ} \mathrm{C}$-on porlasztott (20 at\% Ti EDS-sel) C - Ti vékonyréteg esetén, Martínez és mtsai $\mathrm{H}^{3} / \mathrm{E}^{2}=0,31 \mathrm{GPa}$ értéket mutattak ki maximális keménységű mintájuk esetén $(75-85$ ${ }^{\circ} \mathrm{C}$-os gyártási hőmérséklet), míg Musil és mtsai $\mathrm{H}^{3} / \mathrm{E}^{2}=0,34$ GPa-t mértek szobahőmérsékleten készített mintájukon. Munkánkban, ebben a tekintetben szobahömérsékleten is jobb eredményt $\left(\mathrm{H}^{3} / \mathrm{E}^{2}=0,37 \mathrm{GPa}\right)$ értünk el.

A TiC/a:C nanokompozit vékonyrétegek súrlódási együtthatóját $(\mathrm{CoF}, \mu)$ nagyrészt a titán és a szén koncentrációja határozza meg. A rétegek $\mathrm{CoF}$ értékeit a $\mathrm{Ti}$ tartalom függvényében a 24b. ábra illusztrálja. 

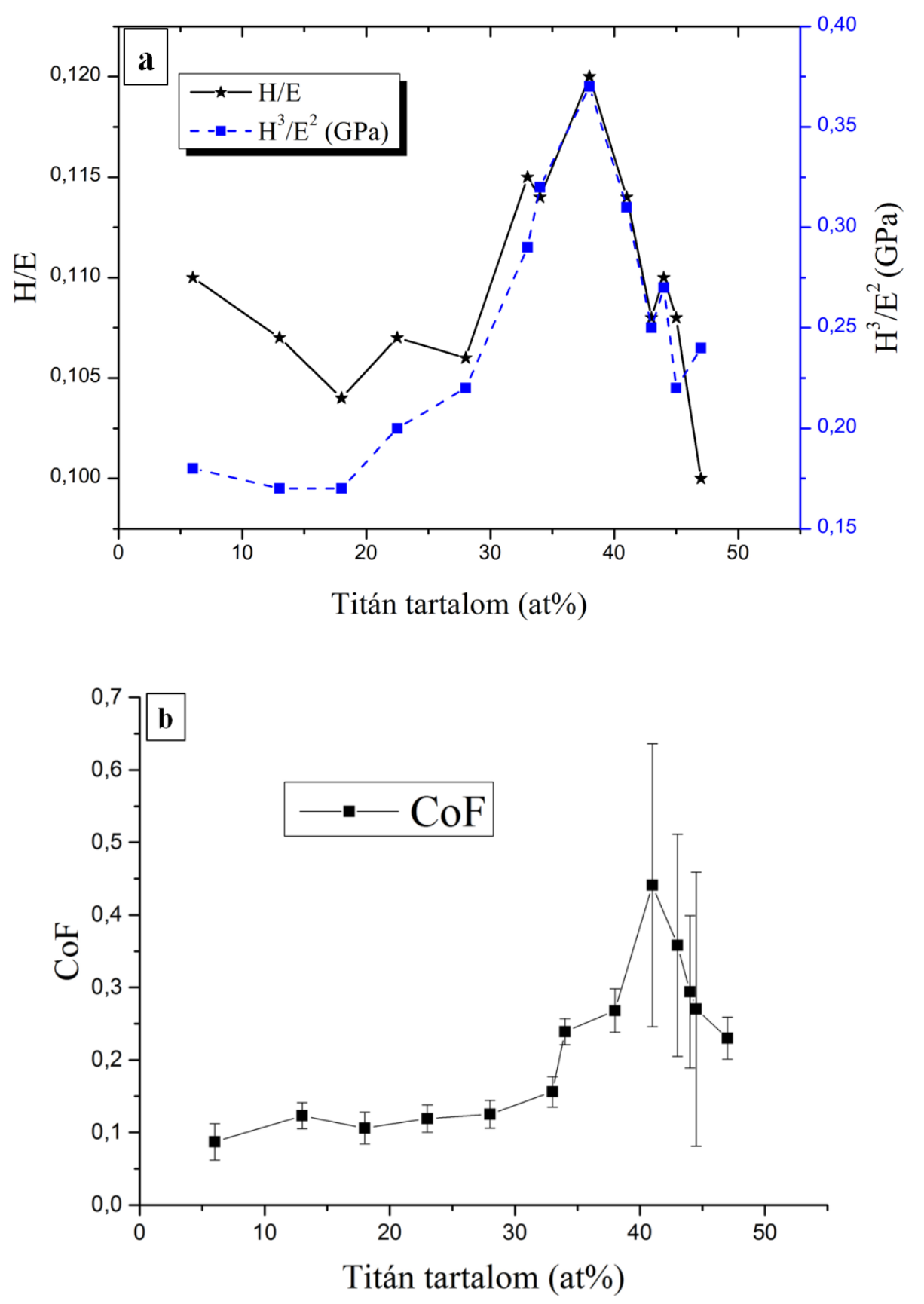

24. ábra a) A H/E és a $H^{3} / E^{2}$ értékek összehasonlítása és b) a különbözö Ti tartalmú TiC/a:C vékonyrétegek súrlódási együttható (CoF) értékei a titán tartalom függvényében.

A $\mu=0,441$ legnagyobb értékét 41 at\% Ti koncentrációnál mértük, míg 38 at\% Ti tartalomnál a CoF értéke $\mu=0,268$-nak mutatkozott. Meg kell említeni, hogy az oxidált Si hordozó CoF-értéke $\mu=0,58$ volt. Amikor a Ti koncentrációja 6 és 33 at\% között van, a súrlódási együttható értékei 0,087 és 0,156 között változnak, mely értékek az a:C fázis önkenési viselkedésével magyarázhatóak [136][148]. Amikor a Ti koncentráció meghaladja a 
34 at\% -ot, a súrlódási együttható értékei 0,23 (vö. 0,24 [26]) és 0,441 között változnak. Ezek az értékek megfelelnek a szén-fém, mint pl. TiCN, TiC, nanokompozitok súrlódási együtthatóinak [134][27][149].

Kísérleteim folytatásaként a legjobb mechanikai tulajdonságokkal rendelkező 38 at\% Ti koncentrációjú, valamint a 43 at\% titánt tartalmazó réteget vizsgáltam tovább a már említett CP titán, sima és szemcseszórt felületü TiAl6V4 ötvözetủ és szemcseszórt felületü CoCrMo ötvözetü fém hordozókon. A porlasztás paraméterei az 5.1. fejezetben vannak részletezve. Az állandó $150 \mathrm{~W}$-os $\mathrm{C}$ teljesítmény mellett a Ti teljesítmény is állandó, 40 - 50 W volt. A TiAl6V4 és CoCrMo fedetlen anyagot a hordozó egyik oldalának $60 \mu \mathrm{m}$ szemcseméretű korund részecskékkel $\left(\mathrm{Al}_{2} \mathrm{O}_{3}\right)$ való homokfúvásos eljárásával durvítottuk fel a jobb tapadás érdekében. A CoCrMo hordozót, mint referencia anyagot, csak az első korróziós tesztek során használtam, mivel egyrészt a legrosszabb korróziós tulajdonságokkal ennek a felületére felvitt réteg rendelkezett (ld. később), másrészt implantátum anyagként ezt az ötvözetet már alig használják.

A CoCrMo hordozóra porlasztott rétegen kívül, a többi rétegen XPS elemzést is végeztünk. A korábbi, szintén $40-50 \mathrm{~W}$ Ti porlasztási teljesítmény mellett végzett kísérletekkel elvégeztem az összehasonlítást az összetétel és reprodukálhatóság feltárása érdekében. A kapott eredményeket a 2. táblázat foglalja össze.

A réteg vastagságának optimalizálása érdekében különböző vastagságú rétegeket porlasztottam (2. táblázat). Fémhordozók esetében a $700 \mathrm{~nm}$-es rétegek a nanoindentációs és tribológiai vizsgálatok könnyebb kivitelezését és az eredmények egyszerübb értékelését szolgálták. Függetlenül a rétegek vastagságától és a hordozó milyenségétől, hibahatáron belül egy jó korreláció figyelhető meg a $\mathrm{P}_{\mathrm{Ti}}=40 \mathrm{~W}$ porlasztási teljesítménynél (négy különböző réteg) és a $\mathrm{P}_{\mathrm{Ti}}=50 \mathrm{~W}$ porlasztási teljesítménynél (három különböző réteg) készült bevonatok összetételei között. A TiC/a:C nanokompozit vékonyrétegek bizonyítottan reprodukálhatóak, elemi összetételük a céltárgyak porlasztási teljesítményének függvényében változik, ugyanakkor nem függ sem az alkalmazott hordozótól, sem pedig a réteg vastagságától.

A Ti hordozó H (a) és E (b) értékei összehasonlítva azok 38,8 \pm 4 at\% Ti tartalmú TiC/a:C-el bevont értékeivel a 25. ábrán láthatóak. A TiAl6V4 hordozó H (c) és $\mathrm{E}$ (d) értékei azok 39,9 \pm 4 at\% Ti tartalmú TiC/a:C vékonyréteggel bevont értékeivel a 26. ábrán kerülnek bemutatásra. 


\begin{tabular}{|c|c|c|c|c|c|}
\hline Vékonyrétegek & $\begin{array}{c}\mathrm{P}_{\mathrm{Ti}} \\
(\mathrm{W})\end{array}$ & $\mathrm{Ti}(\mathrm{at} \%)$ & $\begin{array}{c}\text { Teljes C } \\
\text { tartalom } \\
(\text { at\% })\end{array}$ & $\mathrm{O}$ (at\%) & Ar (at\%) \\
\hline $\begin{array}{c}400 \mathrm{~nm} \text { vastag TiC/a:C réteg } \\
\mathrm{SiO}_{2} / \mathrm{Si} \text { hordozón }\end{array}$ & 40 & $33,4 \pm 3$ & $59,6 \pm 6$ & $3,9 \pm 1$ & $3,1 \pm 1$ \\
\hline $\begin{array}{c}150 \mathrm{~nm} \text { vastag TiC/a:C réteg } \\
\mathrm{SiO}_{2} / \mathrm{Si} \text { hordozón }\end{array}$ & 40 & $37,7 \pm 4$ & $62,2 \pm 7$ & $1,4 \pm 1$ & $1,8 \pm 0,3$ \\
\hline $\begin{array}{c}700 \mathrm{~nm} \text { vastag TiC/a:C réteg } \\
\text { Ti hordozón }\end{array}$ & 40 & $38,8 \pm 4$ & $56,9 \pm 6$ & $3,3 \pm 0,6$ & $1 \pm 0,3$ \\
\hline $\begin{array}{c}700 \mathrm{~nm} \text { vastag TiC/a:C réteg } \\
\text { TiAl6V4 hordozón }\end{array}$ & 40 & $39,9 \pm 4$ & $57,4 \pm 6$ & $1,9 \pm 0,6$ & $0,9 \pm 0,3$ \\
\hline $\begin{array}{c}400 \mathrm{~nm} \text { vastag TiC/a:C réteg } \\
\mathrm{SiO} / \text { Si hordozón }\end{array}$ & 50 & $39,7 \pm 4$ & $52,4 \pm 10$ & $4,1 \pm 1$ & $3,7 \pm 1$ \\
\hline $\begin{array}{c}150 \mathrm{~nm} \text { vastag TiC/a:C réteg } \\
\mathrm{SiO} \text { / Si hordozón }\end{array}$ & 50 & $43,4 \pm 4$ & $56,6 \pm 7$ & $7,1 \pm 1$ & $1,5 \pm 0,3$ \\
\hline $\begin{array}{c}400 \mathrm{~nm} \text { vastag TiC/a:C réteg } \\
\text { szemcseszórt TiAl6V4 hordozón }\end{array}$ & 50 & $40,2 \pm 4$ & $43,2 \pm 8$ & $14,9 \pm 0,6$ & $1,6 \pm 0,3$ \\
\hline
\end{tabular}

2. táblázat: Azonos feltételek mellett porlasztott TiC/a:C vékonyrétegekben lévö összetevök koncentrációjának összehasonlítása a Ti céltárgy porlasztási teljesítményének függvényében ( $P_{T i}=40 \mathrm{~W}$ négy különbözö rétegre és $P_{T i}=50 \mathrm{~W}$ három különbözö rétegre).

Mindkét hordozó esetében, az optimális TiC/a:C bevonattal ellátott implantátum anyagok H értékei sokszorosan jobbak, mint rétegek nélkül. A kapott értékek hibahatáron belül megegyeznek, a $\mathrm{SiO}_{2}$-ra porlasztott réteg $\mathrm{H}$ értékeivel, vagyis a Ti hordozóra felvitt TiC/a:C vékonyréteg keménysége $28 \mathrm{GPa} \pm 3$ (25a. ábra) és $27 \mathrm{GPa} \pm 2$ a TiAl6V4 hordozóra porlasztott réteg esetében (26a. ábra). Ezek az értékek 3,5 GPa $\pm 0,2$ a fedetlen Ti esetében és $5 \mathrm{GPa} \pm 0,2$ a fedetlen TiAl6V4 ötvözet esetében. A súrlódási érték együtthatója szintén kedvező a TiC/a:C vékonyréteg esetében, mely $\mu=0,20 \pm 0,07$-nek adódott összehasonlítva a réteg nélküli Ti $\mu=0,72 \pm 0,08$ és réteg nélküli TiAl6V4 alapfémek $0,60 \pm$ 0,04-es súrlódási együttható értékeivel.

A mérések bizonyitják, hogy az alap implantátumok tribológiai tulajdonságai nagyjából háromszorosan javulnak az optimális TiC/a:C nanokompozit bevonat felvitelével. Ezek a legmegfelelőbb összetételü bevonatok a mechanikai és tribológiai tulajdonságok szempontjából. A rugalmassági modulusz értékek tekintetében az alapfémek kisebb értékekkel rendelkeznek. Ez a réteg nélküli Ti hordozó esetében $125 \mathrm{GPa} \pm 15$ (25b. ábra), 
míg a réteg nélküli TiAl6V4 hordozón $130 \mathrm{GPa} \pm 10$ (26b. ábra). Ezek az értékek $280 \mathrm{GPa} \pm$ 40 TiC/a:C bevont Ti-ra és $270 \pm 20$ a réteggel fedett TiAl6V4 ötvözetre.
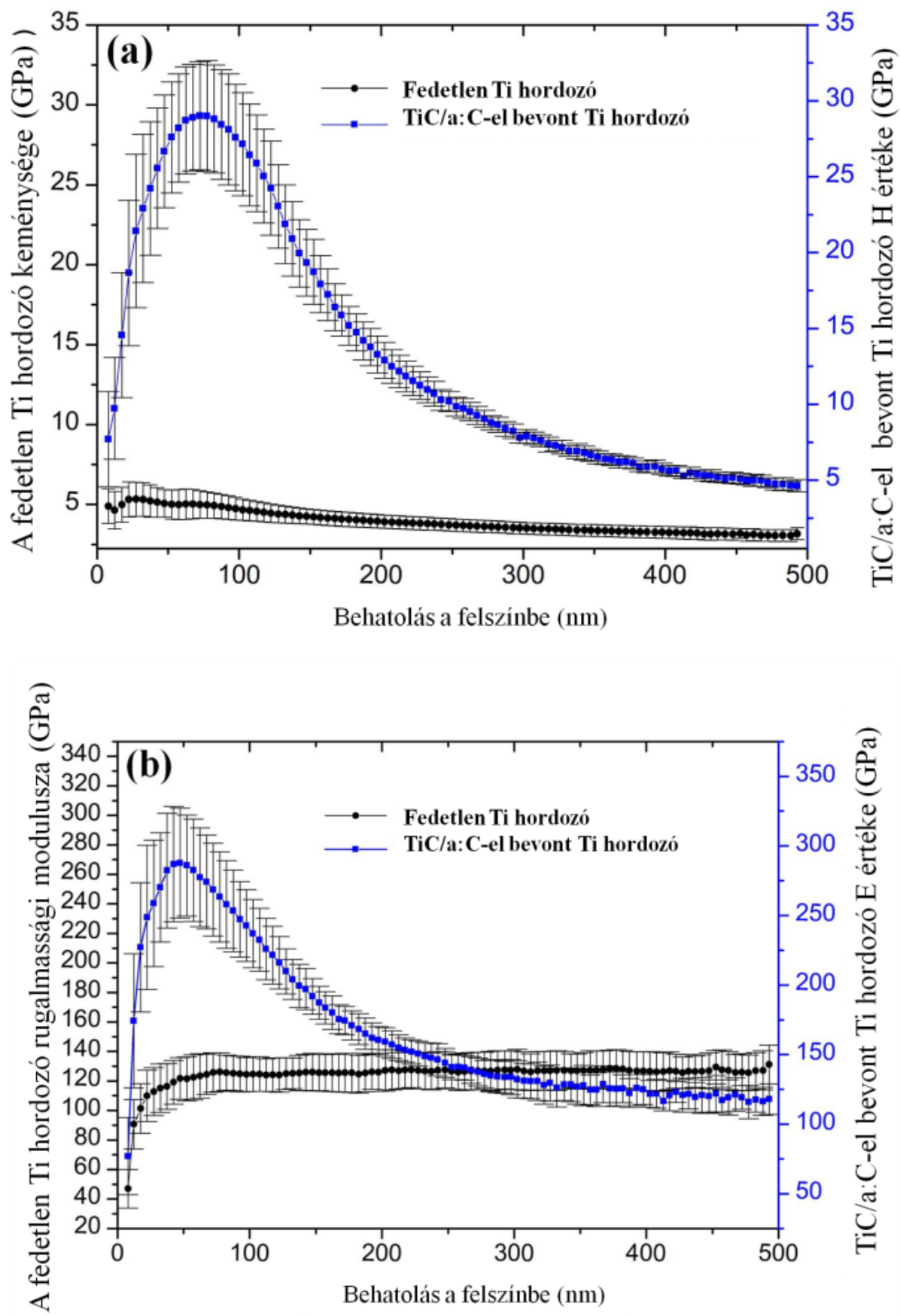

25. ábra: A bevonat nélküli és TiC/a:C bevonattal ellátott Ti hordozó H (a) és E (b) értékeinek összehasonlitása. 

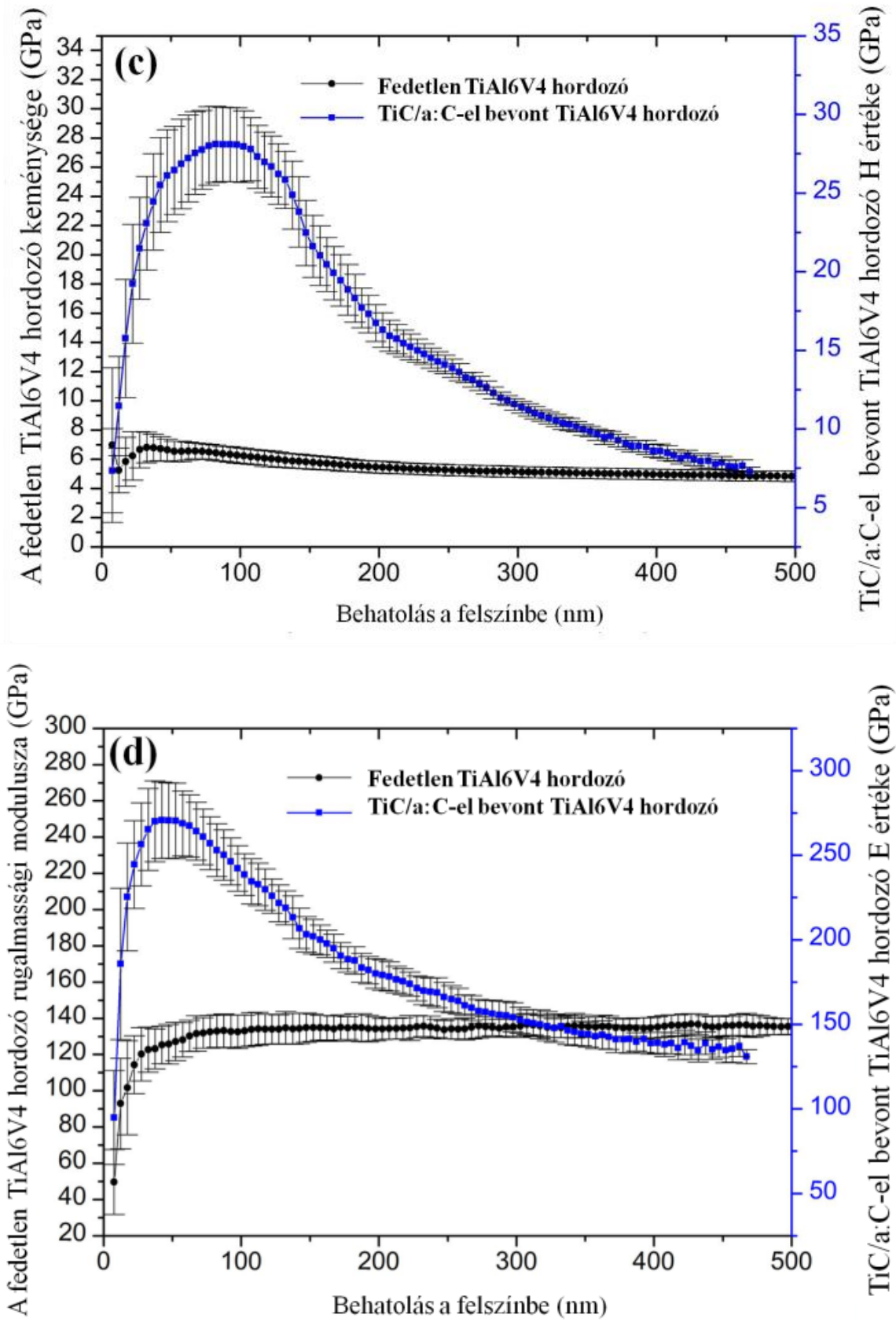

26. ábra: A bevonat nélküli és TiC/a:C bevonattal ellátott TiAl6V4 hordozó H (c) és E (d) értékeinek összehasonlitása.

\subsection{Korróziós vizsgálatok eredményei}

\subsubsection{A minták korróziós vizsgálata 3 különbözö pH értékü oldatban}

A potenciodinamikai polarizációs mérések értékesek lehetnek annak megítélésében, hogy egy adott anyag miként fog viselkedni különféle agresszív környezetnek kitéve. Mivel a TiC alkalmazási területe igen széles körü, lsd. 2.1.2. fejezet, a későbbi alap-, ipari-, mérnöki-, 
és orvosi alkalmazásokban történő felhasználhatóságára való tekintettel korróziós tulajdonságait három különböző oldatban vizsgáltuk. A potenciodinamikai polarizációs görbéket mind a TiC/a:C bevonattal ellátott mintákon, mind a réteg nélküli ötvözeteken (27. ábra) felvettük. A különböző elektrolit oldatokban végzett mérések során a polarizációs görbéket 30 perces bemerítési idő után vettük fel, majd Tafel extrapolációs módszerrel értékeltük. A korróziós áram ( $\mathrm{j}_{\mathrm{k} \text { orr. }}$ ) és potenciál értékek meghatározásához a Tafel görbék anódos $(\beta a)$ és katódos $(\beta c)$ ágára érintő egyeneseket illesztettünk és a két egyenes metszéspontjából leolvastuk a megfelelő értékeket. A $\mathrm{j}_{\text {korr. }}$ értékek mutatták meg a minták korrózióval szembeni ellenállóságát. Minél nagyobb volt a korróziós áram értéke, illetve minél negatívabb a korróziós potenciál, annál kevésbé korrózióálló a minta.
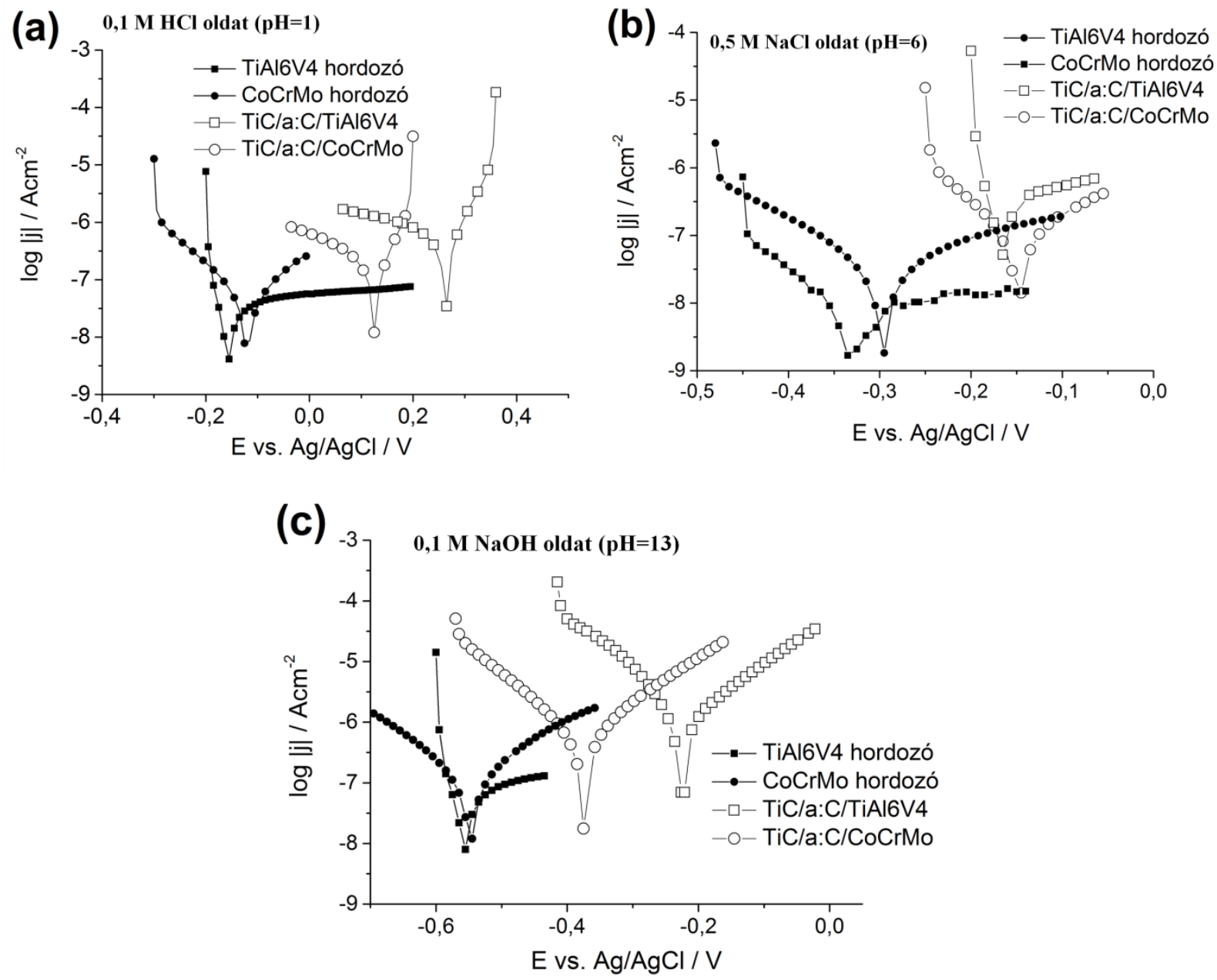

27. ábra: Tafel görbék bevonat nélküli és TiC/a:C réteggel bevont TiAl6V4 illetve

CoCrMo implantátum anyagokon. Azx tengelyen a mintákra vonatkozó potenciál értékeket ábrázoltam az $\mathrm{Ag} / \mathrm{AgCl}$ referencia elektród ellenében. 
A görbéken jól látható, hogy a TiC/a:C bevonattal ellátott hordozók korróziós potenciáljai nagyjából 150 - $400 \mathrm{mV}$-tal pozitívabb értékek felé tolódnak az alapfémekéhez képest. A korróziós potenciál értékek a pH emelkedésével egyidejűleg, minden esetben a pozitívabb irány felé tolódnak.

A korróziós áramok és a korróziós potenciál mennyiségi információit a görbék meredekségéből a Stern-Geary egyenlet (5) [73] felhasználásával lehet meghatározni. Általánosan elmondható, hogy a korróziós áram fordítottan arányos a korróziós ellenállással $\left(\mathrm{R}_{\mathrm{p}}\right)$ a következö összefüggés szerint:

$$
\mathrm{j}_{\mathrm{korr} .}=\frac{\beta_{\mathrm{a}} \times \beta_{\mathrm{c}}}{2,303 \times \mathrm{R}_{\mathrm{p}} \times\left(\beta_{\mathrm{a}} \times \beta_{\mathrm{c}}\right)}
$$

- $j_{\text {korr }}$ a korróziós áram $\mathrm{A} / \mathrm{cm}^{2}$-ben;

- $R_{p}$ a minta felületén lejátszódó elektrokémiai folyamatok polarizációs ellenállása $\Omega \cdot \mathrm{cm}^{2}$ ben. Minél nagyobb az értéke, annál korrózióállóbb a minta.

- $\beta a$ a Tafel görbe anódos ágának meredeksége Volt/áramsürüség tizede mértékegységben;

- $\beta c$ a Tafel görbe katódos ágának meredeksége Volt/áramsürüség tizede mértékegységben $[150]$.

\begin{tabular}{|c|c|c|c|c|c|}
\hline Minta & Oldat & $\begin{array}{l}\text { Korróziós } \\
\text { áram } \\
\mathrm{nA} / \mathrm{cm}^{2}\end{array}$ & $\begin{array}{c}\text { Korróziós } \\
\text { potenciál } \\
\mathrm{mV}\end{array}$ & $\begin{array}{c}\mathrm{R}_{\mathrm{p}} / \\
\mathrm{k} \Omega \cdot \mathrm{cm}^{2}\end{array}$ & $\begin{array}{c}\mathrm{R}_{\mathrm{ct}} / \\
\mathrm{k} \Omega \cdot \mathrm{cm}^{2}\end{array}$ \\
\hline \multirow{3}{*}{$\begin{array}{l}\text { TiAl6V4 } \\
\text { hordozó }\end{array}$} & $0,5 \mathrm{M} \mathrm{NaCl}$ & 5,61 & $-287,5$ & 32,92 & 31180 \\
\hline & $0,1 \mathrm{M} \mathrm{HCl}$ & 40,44 & -177 & 37,79 & 25070 \\
\hline & $0,1 \mathrm{M} \mathrm{NaOH}$ & 89,01 & -560 & 26,54 & 8252 \\
\hline \multirow{3}{*}{$\begin{array}{l}\text { TiC/a:C/ } \\
\text { TiAl6V4 }\end{array}$} & $0,5 \mathrm{M} \mathrm{NaCl}$ & 93,8 & -172 & 20,75 & 306,4 \\
\hline & $0,1 \mathrm{M} \mathrm{HCl}$ & 278 & +280 & 89,98 & 280,5 \\
\hline & $0,1 \mathrm{M} \mathrm{NaOH}$ & 1595 & -227 & 62,3 & 204,2 \\
\hline \multirow{3}{*}{$\begin{array}{l}\text { CoCrMo } \\
\text { hordozó }\end{array}$} & $0,5 \mathrm{M} \mathrm{NaCl}$ & 36,8 & $-101,9$ & 25,49 & 568,7 \\
\hline & $0,1 \mathrm{M} \mathrm{HCl}$ & 138,8 & $-111,7$ & 15,93 & 408,2 \\
\hline & $0,1 \mathrm{M} \mathrm{NaOH}$ & 186,8 & -550 & 16,77 & 170,2 \\
\hline \multirow{3}{*}{$\begin{array}{l}\text { TiC/a:C/ } \\
\text { CoCrMo }\end{array}$} & $0,5 \mathrm{M} \mathrm{NaCl}$ & 57,9 & $-138,5$ & 43,41 & 227,3 \\
\hline & $0,1 \mathrm{M} \mathrm{HCl}$ & 158 & $+141,6$ & 17,95 & 222,6 \\
\hline & $0,1 \mathrm{M} \mathrm{NaOH}$ & 632 & -373 & 22,87 & 35,9 \\
\hline
\end{tabular}

\section{3. táblázat: Tafel görbék kiértékelése.}


Mint azt a 3. táblázat is jól mutatja, a TiC/a:C bevonattal ellátott fém hordozók korróziós potenciálja minden esetben pozitívabb, mint a fedetlen hordozóké, ugyanakkor korróziós áramsürüségük közel egy nagyságrenddel nagyobb, mint az alapfémek esetében.

A Tafel görbék kiértékeléséből látható (3. táblázat), hogy szisztematikusan minden minta esetében a legnagyobb korróziós áramot és legnegatívabb korróziós potenciált lúgos közegben $(0,1 \mathrm{M} \mathrm{NaOH})$ mérhetjük, míg a legkisebb korróziós áram semleges $\mathrm{NaCl}$ oldatban mutatható ki. Az alapfémek esetében minden esetben kisebb korróziós áramok mérhetőek, mint a TiC/a:C réteggel bevont mintákon. A leginkább pozitív értéket a TiC/a:C réteggel bevont TiAl6V4 (+280 mV) esetében a 0,1 M HCl oldatban kaptuk, míg a legnegatívabb ($550 \mathrm{mV}$ ) értéket a CoCrMo alapfémnél a $0,1 \mathrm{M} \mathrm{NaOH}$ oldatban. A legkisebb korróziós áramot $(5,61 \mathrm{nA})$ TiAl6V4 alapfém esetében mértük 0,5 $\mathrm{M} \mathrm{NaCl}$ oldatban, míg a legnagyobbat (1595 nA) TiC/a:C réteggel bevont TiAl6V4 mintánál 0,1 M NaOH oldatban, ugyanakkor $0,1 \mathrm{M} \mathrm{NaOH}$ oldatban és $0,1 \mathrm{M} \mathrm{HCl}$ oldatban az alapfémek korróziós potenciálja minden esetben negatívabb tartományban van, mint a bevont implantátum anyagok korróziós potenciáljai. Ez alól kivétel a CoCrMo alapfém, mely $0,5 \mathrm{M} \mathrm{NaCl}$ oldat esetében pozitívabb (-101,9 mV), mint TiC/a:C/CoCrMo minta (-138,5 mV) ugyanezen oldatban.

A minták korróziós ellenállását az $R_{c t}$ töltésátviteli ellenállás mutatja, mely a határfelületen keresztüli elektronátvitelre utal és tükrözi a korróziós bomlást. Minél nagyobb $\mathrm{R}_{\mathrm{ct}}$ ellenállás, annál korrózióállóbb a minta. A fedetlen CoCrMo és a TiAl6V4 hordozók $\mathrm{R}_{\mathrm{ct}}$ értékei, a jkorr. értékekkel összhangban, 4 - és 7-szer nagyobbak, mint a TiC/a:C/TiAl6V4 és TiC/a:C/CoCrMo minták esetében, míg a réteg $R_{p}$ értékei minden esetben 4 - 5-ször

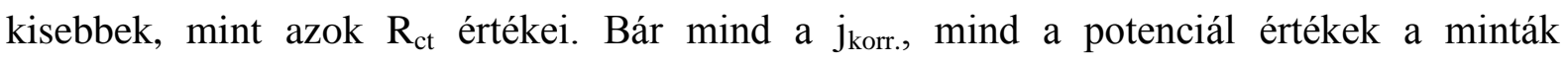
korrózióval szembeni ellenállóságát hivatottak jellemezni, a korróziós áramsűrüségi adatok sokkal inkább reprezentálják az anyagok korróziós sebességét, mint a korróziós potenciál értékek, így a továbbiakban ez lesz a mérvadó.

A potenciodinamikus mérések alapján kimutatható, hogy az alapfémek mindhárom vizsgált oldatban jobban ellenállnak a korróziónak, mint a TiC/a:C réteggel bevont hordozók és a bevonat nélküli TiAl6V4 korróziós áram értékei jelentős mértékben alacsonyabbak, mint a CoCrMo alapfémé, amint azt Swaminathan és mtsai is megmutatták [151]. A kapott mérési eredmények alapján a legnagyobb korróziós hajlamot tehát a TiC/a:C réteggel bevont TiAl6V4 minta mutatta $0,1 \mathrm{M} \mathrm{NaOH}$ oldatban, míg a legjobban korrózióálló minta a TiAl6V4 alapötvözet volt $0,5 \mathrm{M} \mathrm{NaCl}$ oldatban.

Az impedancia spektrumokat mindkét összetett impedancia diagramban (Nyquist és Bode diagram) ábrázoltuk. A Nyquist diagram az impedancia valós részének ábrázolása a 
képzetes rész abszolút értékének függvényében: $Z=\operatorname{Re}+\operatorname{Rp} /\left(1+(j \omega \tau)^{\beta}\right)(0<\beta \leq 1)$, míg a Bode diagram a totál impedancia értékek $(Z)$ és a fázisszög $|\phi|$ abszolút értékének ábrázolása a frekvencia logaritmusának függvényében. A vizsgált mintákat elöször belemerítettük az adott oldatba, és a minta felületének stabilizálása céljából nyitott áramkörökön hagytuk őket 30 percig. A 28. ábra szemlélteti a TiC/a:C réteggel bevont implantátum hordozók Nyquist (bal oldal) és Bode digramjait (jobb oldal) nyitott áramkörön. A vizsgált oldatokban a potenciodinamikai mérésekből nyert korróziós potenciálok szisztematikusan kisebbek voltak, mint a nyitott áramköri potenciáloknak megfelelő értékek, ami a katódos pásztázás során, a felületen található depasszivációs jelenségnek tulajdonítható.
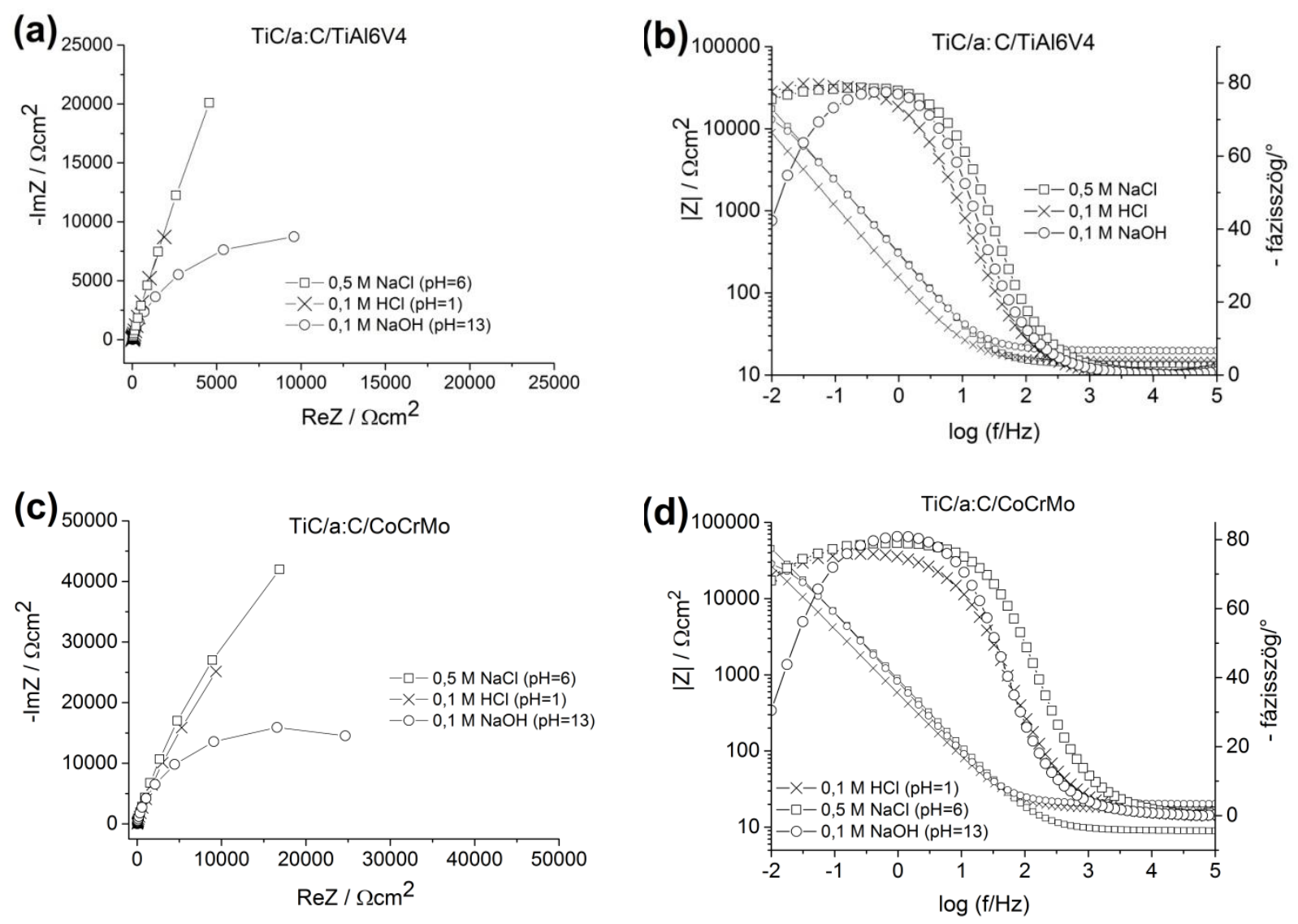

28. ábra: TiC/a:C réteggel bevont implantátum anyagok impedancia diagramjai

\section{különbözö elektrolit oldatokban (a) Nyquist, (b) Bode, (c) Nyquist, (d) Bode diagramok.}

A minták korróziós tulajdonságaira vonatkozó kiértékelés alkalmas módja a Nyquistféle félkörök átméröinek összehasonlítása: minél nagyobb ez az ún. Nyquist-átmérő, annál jobb a minta korrózióállósága. A Nyquist-diagramok félkörívének átmérője is azt mutatja, hogy a minták a $0,1 \mathrm{M} \mathrm{NaOH}$ oldatban hajlamosak leginkább a korrózióra, míg a 0,5 $\mathrm{M} \mathrm{NaCl}$ 
oldatban rendelkeznek a legjobb felületi ellenállással. A 0,5 M NaCl-ban és a 0,1 M HCI oldatban felvett Nyquist-diagramok jelentősen nagyobb kapacitív hurkot mutatnak elérve a $80^{\circ}$-os fázisszöget a közepes és alacsony frekvenciatartományban, ami túlnyomóan kapacitív viselkedésre utal. Lúgos oldatban a Nyquist-diagramok nagyobb mértékben hajlanak az impedancia tengely valós részéhez nyomottabb félkört kialakítva, míg a nekik megfeleltethető Bode diagramokban a fázisszög nagyjából $-78^{\circ}$-kal megközelíti a középső frekvenciatartományban a keskenyebb frekvenciatartományt $10 \mathrm{~Hz}$-ről $0,1 \mathrm{~Hz}$-re mindkét minta esetében.

A $0,5 \mathrm{M} \mathrm{NaCl}$ oldatnak kitett bevonattal ellátott és bevonat nélküli minták impedancia adatainak értékelését nyílt áramkörben részletesebben is elvégeztük (29. ábra).
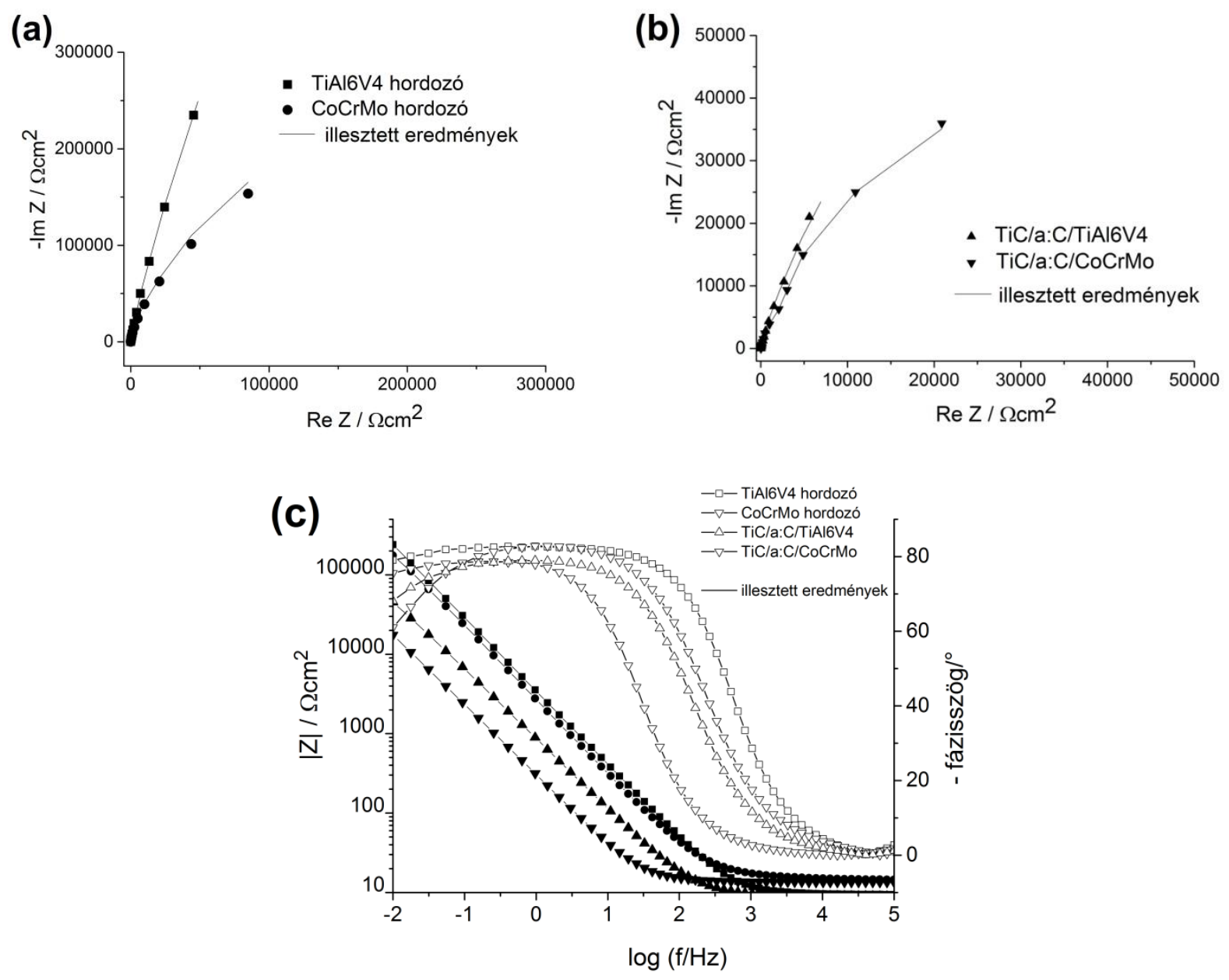

29. ábra: A TiC/a:C bevonattal ellátott és bevonat nélküli fémes implantátumok a), b) Nyquist és c) Bode impedancia spektrumai 0,5 M NaCl oldatban a saját nyitott áramköri potenciáljuknál. 
A 29. ábrán (a, b) látható, hogy a bevonat nélküli alapfémek csaknem egy nagyságrenddel jobb korrózióállóságot mutatnak a TiC/a:C bevonattal ellátott mintákkal szemben, ami a felületükön spontán képződött sűrü, kompakt és homogén oxidréteggel magyarázható. A Nyquist diagram 29a. ábrája szerint ugyanakkor a TiAl6V4 hordozón sokkal tömörebb oxidréteg tapasztalható, mint a CoCrMo hordozón. Ezt alátámasztja Y. Okazaki és munkatársainak megállapítása is, miszerint a Ti ötvözet magasabb korróziós ellenállással rendelkezik, mint a Co-Cr ötvözet, hiszen a Co-Cr ötvözeten képződött passzív réteg nem stabil és könnyen lebomlik [152]. TiAl6V4 alapfém esetében a Nyquist diagram nagy kapacitív íveket mutat, míg a CoCrMo alapfémre jellemző Nyquist diagram sokkal inkább a valós tengelyhez hajlik és nagy félkör alakú ívü. A 29. c) ábra széles fázisszög maximumot mutat $\left(10^{3}-10^{-1}\right)$, mind a bevonattal ellátott, mind a bevonat nélküli minták esetében. Ezt a részben átfedő időállandóval arányos, közepes (MF) és alacsony frekvenciájú (LF) régióknál egyesülő két fázis maximumának lehet tulajdonítani.

A mintákra vonatkozó impedancia adatok kiértékeléséhez olyan helyettesítő áramkörök használatosak, melyek megfelelően szimulálják az elektródák felületén lejátszódó folyamatokat. Ilyen áramköröket szemléltet a 30. ábra.

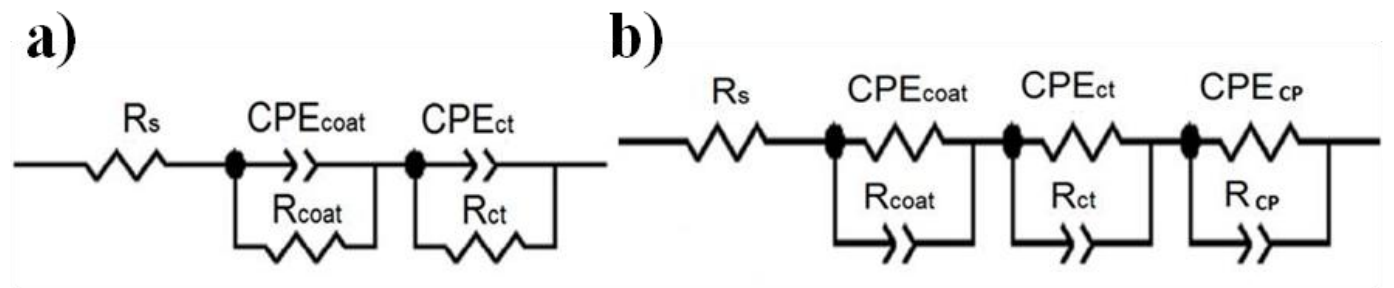

30. ábra: EEC modellek az a) alapfémek (kettös (RC)(RC) modell) és a b) TiC/a:C nanokompozit bevonattal ellátott fém hordozók (háromszoros $(R C)(R C)(R C)$ modell) mért adatainak szimulálására.

Az áramköri modell legáltalánosabb formája az ellenállásokkal és kapacitásokkal felszerelt, hordozókhoz kapcsolódó kettős $(\mathrm{RC})(\mathrm{RC})$ modell. A helyettesítő áramkörben a réteg felületének inhomogenitása, illetve a pórusok miatt egy ideális kettősrétegü kapacitás helyett konstans fáziselemet (CPE) használunk, ami leírja a valódi kondenzátor viselkedésétől való eltérést. Az áramkörben a bevonat illetve a pórusok kapacitását $\mathrm{R}_{\text {coat }}$ helyettesíti.

A konstans fáziselem impedanciája a következő egyenlettel szemléltethető:

$$
\mathrm{Z}_{\mathrm{CPE}}=1 /\left[\mathrm{Q}(\mathrm{j} \omega)^{\mathrm{n}}\right],
$$


ahol $n$ a felületi érdesség és felületi hibák következtében kialakuló nemegyensúlyi árameloszláshoz kapcsolódó kitevő. A 30. ábrán $\mathrm{R}_{\mathrm{s}}$ egy dekompenzált oldatellenállás a réteg és a referencia elektród között. Az 30a. ábrán látható nagyfrekvenciás időállandó $\left(\mathrm{R}_{\text {coat }} \mathrm{CPE}_{\text {coat }}\right)$ a hordozók felületén spontán képződött oxid rétegeknek az impedanciaválaszhoz való hozzájárulására utal. $\mathrm{Az}$ alacsony frekvenciás időállandó $\left(\mathrm{R}_{\mathrm{ct}} \mathrm{CPE}_{\mathrm{ct}}\right)$ a hordozó/oxid réteg határfelületén történő töltésátadási folyamatot írja le, ahol $\mathrm{CPE}_{\mathrm{ct}} \mathrm{a}$ kettősréteg konstans fáziseleme, míg $R_{c t}$ a minta felületén lejátszódó elektrokémiai folyamatok töltésátlépésének az ellenállása.

A TiC/a:C réteggel bevont hordozók esetében a legjobb illeszkedést egy, a hozzájuk kapcsolódó háromszoros $(\mathrm{RC})(\mathrm{RC})(\mathrm{RC})$ áramköri modell adja, melyet a 30b. ábrán látható áramkör szemléltet. A nagyfrekvenciás időállandó $\left(\mathrm{R}_{\text {coat }} \mathrm{CPE}_{\text {coat }}\right)$ a TiC/a:C rétegek impedancia-válaszhoz való hozzájárulására utal, míg az alacsony frekvenciás időállandó $\left(\mathrm{R}_{\mathrm{ct}} \mathrm{CPE}_{\mathrm{ct}}\right)$ a hordozó/bevonat határfelületén történő töltés átadási folyamatot írja le. Ebben $\mathrm{CPE}_{\mathrm{ct}}$ a kettősréteg konstans fáziseleme, míg $\mathrm{R}_{\mathrm{ct}}$ a minta felületén lejátszódó elektrokémiai folyamatok töltésátlépésének az ellenállása. A harmadik sorosan kapcsolt al-áramkör $\left(\mathrm{R}_{\mathrm{cp}} \mathrm{CPE}_{\mathrm{cp}}\right)$ a bemerítési idő alatt a bevonatban keletkezett korróziós termékekre vonatkozik.

\begin{tabular}{|c|c|c|c|c|c|c|c|}
\hline Minta & $\mathrm{R}_{\mathrm{s}} / \Omega \cdot \mathrm{cm}^{2}$ & $\begin{array}{c}\mathrm{CPE}_{\text {coat }} / \\
\mu \mathrm{Fcm}^{-2} \cdot \mathrm{s}^{\mathrm{n}-1}\end{array}$ & $\mathrm{n}$ & $\begin{array}{c}\mathrm{R}_{\mathrm{coat}} / \\
\Omega \cdot \mathrm{cm}^{2}\end{array}$ & $\begin{array}{c}\mathrm{CPE}_{\mathrm{dl}} / \\
\mu \mathrm{Fcm}^{-2} \cdot \mathrm{s}^{\mathrm{n}-1}\end{array}$ & $\mathrm{n}$ & $\chi^{2} / \cdot 10^{-4}$ \\
\hline $\begin{array}{c}\text { TiAl6V4 } \\
\text { hordozó }\end{array}$ & 9,51 & 49,8 & 0,91 & 32,92 & 33,4 & 0,96 & 1,24 \\
\hline $\begin{array}{c}\text { CoCrMo } \\
\text { hordozó }\end{array}$ & 8,93 & 52,4 & 0,91 & 25,49 & 34,7 & 0,92 & 3,46 \\
\hline $\begin{array}{c}\text { TiC/a:C/ } \\
\text { TiAl6V4 }\end{array}$ & 13,55 & 632 & 0,89 & 63,75 & 132 & 0,81 & 4,24 \\
\hline $\begin{array}{l}\text { TiC/a:C/ } \\
\text { CoCrMo }\end{array}$ & 9,04 & 228 & 0,88 & 43,38 & 138 & 0,81 & 4,38 \\
\hline
\end{tabular}

4. táblázat: A bevonat nélküli és a TiC/a:C réteggel bevont implantátum anyagok EEC-böl származó illesztett paraméterei 0,5 M NaCl oldatban.

Az illesztési paraméterek minőségét, vagyis a fittelés jósági fokát a Khi-négyzet próba $\left(\chi^{2}\right)$ értékei alapján osztályoztuk, amik körülbelül $10^{-4}$ nagyságrendbe esnek és a mért és szimulált értékek közötti kiváló egyezést mutatják. Az izotóniás sóoldat az oldatban 
jelenlévő kloridionok miatt alacsony $\left(9-13 \Omega \cdot \mathrm{cm}^{2}\right)$ ellenállást mutat. Ez a nagyság indokolt, mivel az elektrolit ellenállása nem zavarja az impedancia kísérleteket, ugyanakkor a CPE értékek változása a réteg vastagságának, vagy a réteg dielektromos állandójának változása miatt következik be. A CPE magasabb értékei a porózus rétegekre jellemzőek, sokkal nagyobb felületet jeleznek. A TiC/a:C réteggel fedett hordozók tényleges $n$ értékei az alacsony frekvenciatartományban $\left(\mathrm{CPE}_{\mathrm{coat}}\right)$ 0,89 TiC/a:C/TiAl6V4 és 0,88 TiC/a:C/CoCrMo implantátum anyag esetén nem-ideális kondenzátor viselkedésre utalnak, míg magas frekvenciatartományban $\left(\mathrm{CPE}_{\mathrm{dl}}\right)$ 0,91 és 0,92, közel kapacitív viselkedést mutatnak. A bevonat nélküli hordozóknál a 0,91 - 0,96 közötti tényleges $n$ értékek, mind alacsony, mind magas frekvenciatartományban közel kapacitív viselkedést mutatnak. A potenciodinamikai diagramokból származó Stern-Geary formula (5) alapján számított polarizációs ellenállási értékek jól egyeztek az impedancia mérésekből kapott értékekkel.

A TiC/a:C bevonat felületi morfológiája a korróziós teszt előtt és után a pásztázó elektronmikroszkópos képen nem mutatott szignifikáns változást a rétegben egyik hordozó esetében sem (31. - 32. ábra). A rétegek minden esetben a hordozókon maradtak.

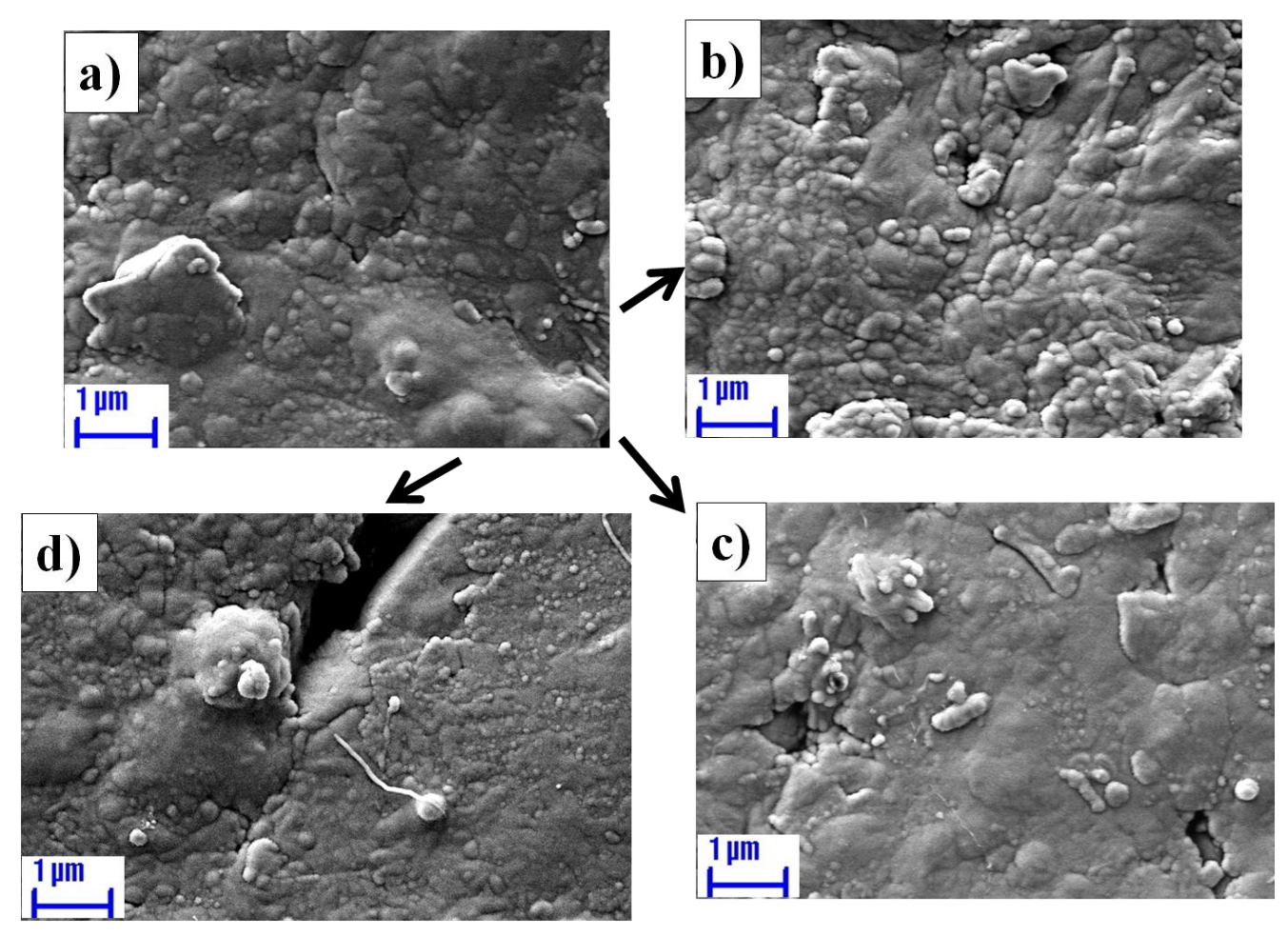

31. ábra: SEM felvételek a TiC/a:C réteggel bevont TiAl6V4 hordozóról a)

korróziós vizsgálatok elött, b) 0,5 M NaCl oldatban végzett vizsgálat után, c) 0,1 M HCl oldatban és d) 0,1 M NaOH oldatban végzett vizsgálat után. 


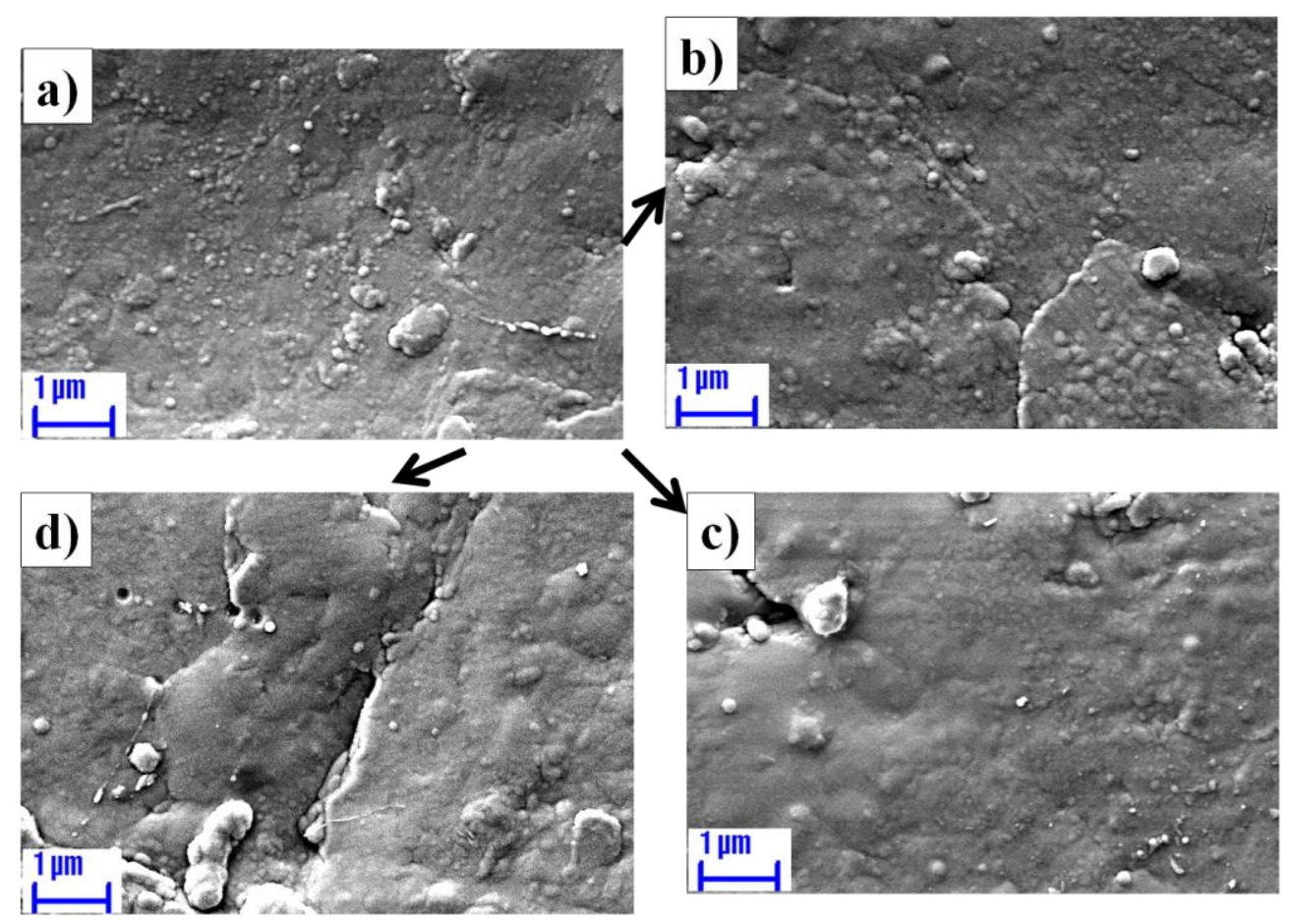

32. ábra: SEM felvételek a TiC/a:C réteggel bevont CoCrMo hordozóról a)

korróziós vizsgálatok elött, b) 0,5 M NaCl oldatban végzett vizsgálat után, c) 0,1 M HCl oldatban és d) 0,1 M NaOH oldatban végzett vizsgálat után.

A hordozók felülete a TiC/a:C rétegek felvitele előtt szemcseszórással volt érdesítve, ezért a SEM felvételek mindegyikén felületi érdesség és inhomogenitás tapasztalható az oldatba mártástól függetlenül. Ezeken felül a 31c-d. és 32c-d. ábrán $1 \mu \mathrm{m}$-t meg nem haladó bemélyedések láthatóak. A szerkezeti vizsgálatok alátámasztják a korróziós vizsgálatok eredményeit, miszerint minden esetben a legkorrozívabb közegnek a 0,1 $\mathrm{M} \mathrm{NaOH}$ oldat mutatkozott (31. és 32d. ábra), tehát a minták a lúgos közeget bírják a legkevésbé. A legkevésbé korrozív közegnek a 0,5 $\mathrm{M} \mathrm{NaCl}$ oldat bizonyult (31. és 32b. ábra), ellentétben a [85][23][86] hivatkozásban foglaltak alapján elvártakkal. Mivel legjobb eredményt a 6-os pH értékü, 0,5 M-os ún. izotóniás sóoldat mutatta, így a réteg emberi szervezetben való későbbi esetleges felhasználásának érdekében, további kísérleteket végeztünk szimulált testnedv folyadékban 7,4-es pH-n és $37^{\circ} \mathrm{C}$-on különböző bemerítési idők mellett. Ennek eredményeit a következő fejezet szemlélteti.

\subsubsection{A minták korróziós vizsgálata SBF oldatban}


Hasonlóan az előzőekben ismertetett korróziós vizsgálatokhoz, ebben az esetben is standard háromelektródos cellában végeztük a potenciodinamikus vizsgálatokat (10. ábra), csak a potenciodinamikai polarizációs görbéket ún. szimulált testnedv folyadékban (SBF) vettük fel. Az elektrolitként szolgáló $\mathrm{SBF}$ oldatot az 5. táblázatban felsorolt reagensek felhasználásával állítottuk elő.

\begin{tabular}{|c|c|}
\hline Reagensek & $\begin{array}{c}\text { Mennyiség } \\
(\mathbf{g} / \mathbf{L})\end{array}$ \\
\hline nátrium-klorid & 7,996 \\
\hline szódabikarbóna & 0,350 \\
\hline kálium-klorid & 0,224 \\
\hline kétbázisú kálium-foszfát-trihidrát & 0,228 \\
\hline magnézium-klorid-hexahidrát & 0,305 \\
\hline 1 M sósav & $40 \mathrm{ml}$ \\
\hline kálcium-klorid & 0,278 \\
\hline nátrium-szulfát & 0,071 \\
\hline trisz (hidroxi-metil) -amino-metán & 6,057 \\
\hline pH & 7,4 \\
\hline
\end{tabular}

5. táblázat: Az SBF kémiai összetétele [153].

Annak érdekében, hogy a TiC/a:C réteggel ellátott minták korrózióérzékenységét összehasonlítsuk a bevonat nélküli hordozókkal, a 33. ábrán potenciodinamikus polarizációs görbéket vettünk fel. Hasonlóan az előző oldatokban végzett kísérlethez, a mintákat először a potenciosztáthoz csatlakoztattuk, majd 30 percig állni hagytuk, hogy beálljon a nyugalmi potenciál. Ezután elindítottuk a mérést. A potenciodinamikai görbéket hosszú idejü bemerítés során többször is rögzítettük és minden egyes mintára megkaptuk az anódos és katódos polarizációs görbéket. A potenciodinamikus mérések pontos ideje a potenciálléptetés idejéből és a felvett potenciáltartománytól függött, míg az impedancia görbék nagyjából fél órát tartottak. Mivel a mérések egyazon mintán zajlottak, így a görbe felvétele után megvártuk, amíg a minta regenerálódik, és ezt követően mértük a következőt. A mérések között a minták folyamatosan az oldatban voltak. A korróziós áram $\left(\mathrm{j}_{\text {korr. }}\right.$ ) és potenciál értékeket szintén, a már ismertetett Tafel extrapolációs módszerrel kaptuk meg. 

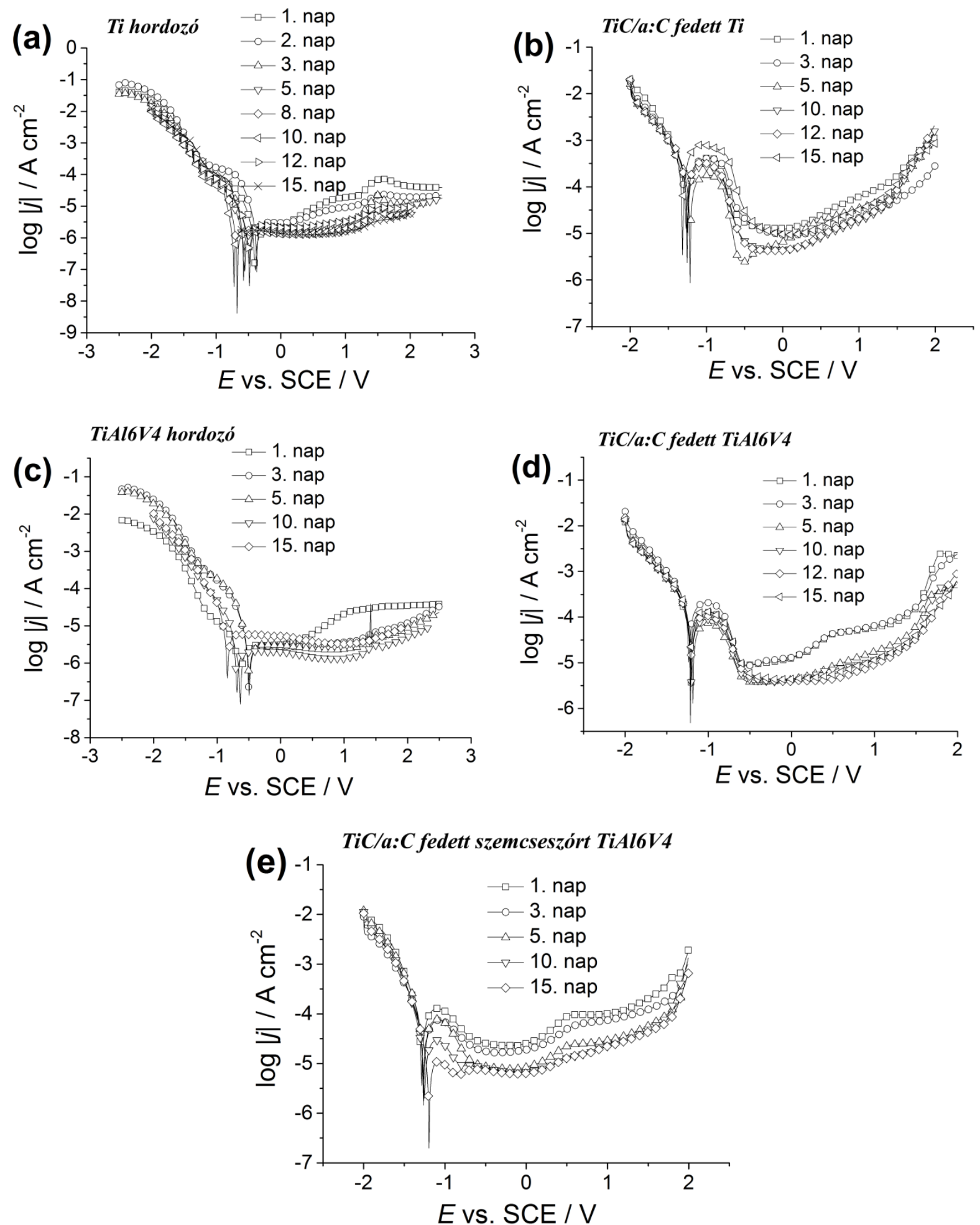

33. ábra: Potenciodinamikus mérések SBF-ben $37^{\circ}$ C-on a TiC/a:C bevonattal ellátott és bevonat nélküli implantátum anyagokon. (a) Ti hordozó (b) TiC/a:C bevonattal ellátott Ti (c) TiAl6V4 hordozó d) TiC/a:C bevonattal ellátott TiAl6V4 és (e) TiC/a:C bevonattal ellátott szemcseszórt felületü TiAl6V4. 
Mint ahogy a 33. ábrán látható, a réteg nélküli hordozók potenciodinamikus görbéinek (Ti: 33a. és TiAl6V4: 33c. ábra) alakja igen hasonló. Ezekben az esetekben a görbék katódos ágai föként kinetikusan szabályozott katódos reakciókat, míg az anódos ágak diffúzió vezérelt anódos folyamatokat mutatnak. Az anódos ágak széles passzív régióval rendelkeznek körülbelül $+1,5 \mathrm{~V}$ potenciálig a telített kalomel elektródhoz (SCE) viszonyítva, mely az anódos túlfeszültségeknél keletkező passzív oxidréteggel magyarázható. A passzív áramsürüség $\left(\mathrm{j}_{\mathrm{p}}\right)$ értékek csökkennek a bemerítési idővel, ugyanakkor 1,5 V-nál magasabb feszültségeknél egy csekély növekedés figyelhetö meg a passzív áramban, ami a passzív oxidréteg elvesztésének tulajdonítható [4]. A fedetlen hordozókkal ellentétben, a TiC/a:C réteggel fedett hordozók potenciodinamikus görbéinek (33b., 33d. és 33e. ábra) alakja igen eltérő. Ezeknél a mintáknál az anódos passzív áram szignifikáns csökkenése jelentkezik a görbék anódos ágainál körülbelül -1 V SCE-hez viszonyítva, nagyméretü passzív területekkel kísérve. A passzív áramok az idő múlásával csökkennek. A TiC/a:C bevonatú anyagok $\mathrm{j}_{\mathrm{p}}$ értékei minden esetben körülbelül egy nagyságrenddel nagyobbak.

Az impedancia spektrumokat ennél a mérésnél is mindkét összetett impedancia diagramban (Nyquist és Bode diagram) ábrázoltuk. A Nyquist diagram az impedancia valós részének ábrázolása a képzetes rész abszolút értékének függvényében: $Z=R e+R p /(1+$ $\left.(j \omega \tau)^{\beta}\right)(0<\beta \leq 1)$, míg a Bode diagram a totál impedancia értékek $(Z)$ és a fázisszög $|\phi|$ abszolút értékének ábrázolása a frekvencia logaritmusának függvényében. A vizsgált mintákat először belemerítettük az SBF oldatba, és a minta felületének stabilizálása céljából nyitott áramkörön hagytuk őket 30 percig. A 34. ábra szemlélteti a TiC/a:C réteggel bevont implantátum hordozók Nyquist (bal oldal) és Bode digramjait (jobb oldal) nyitott áramkörökön. 
(a)

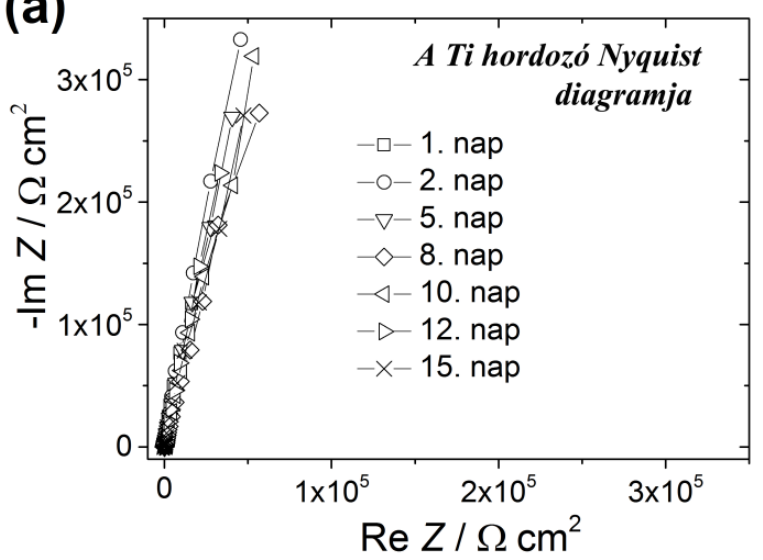

(c) $)_{2,0 \times 10^{5}}$

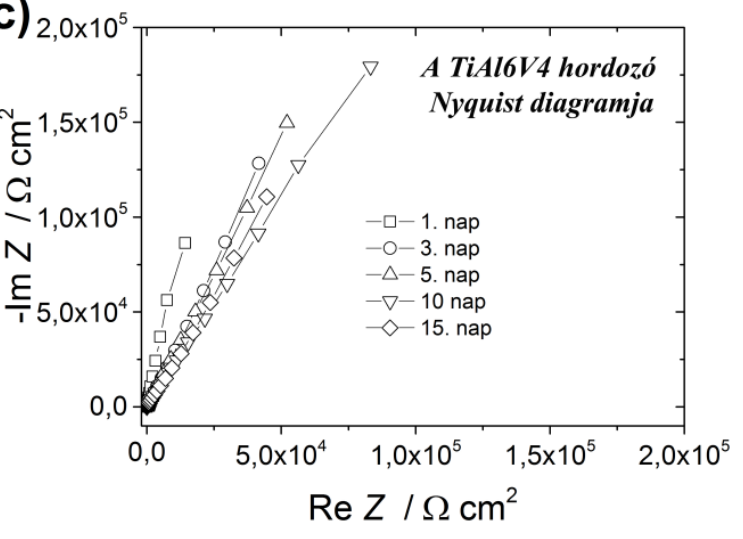

(e)
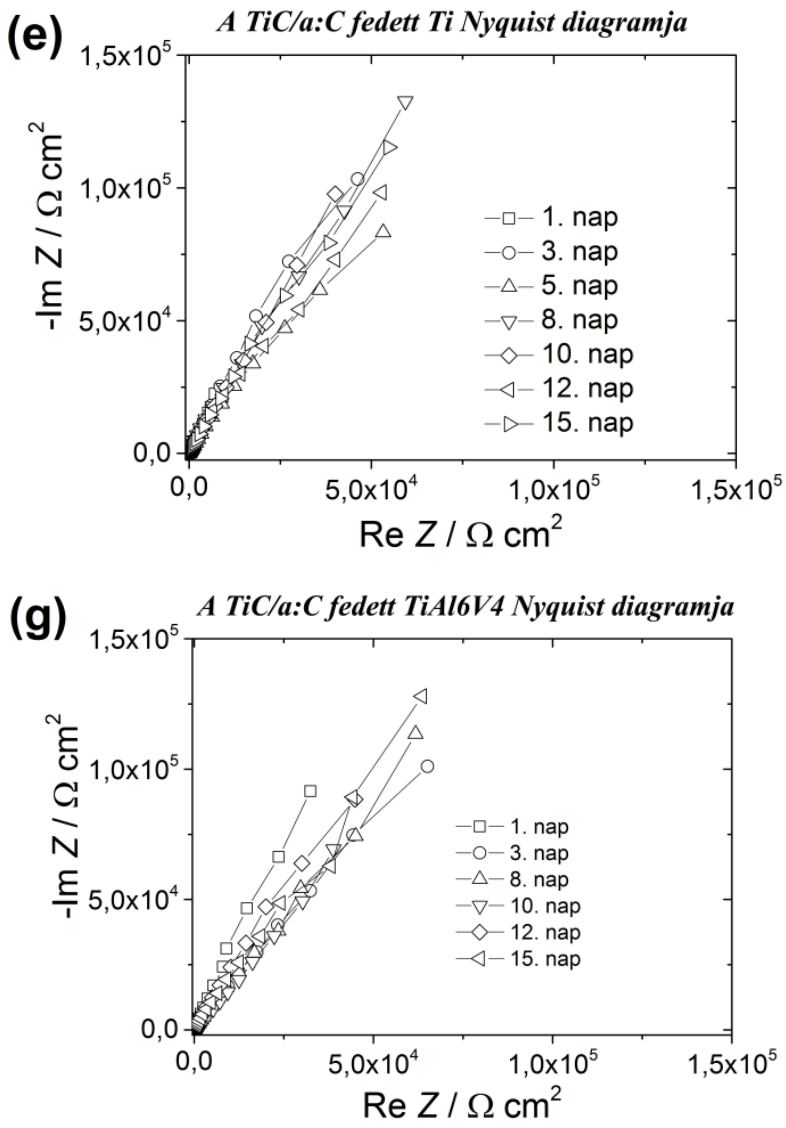
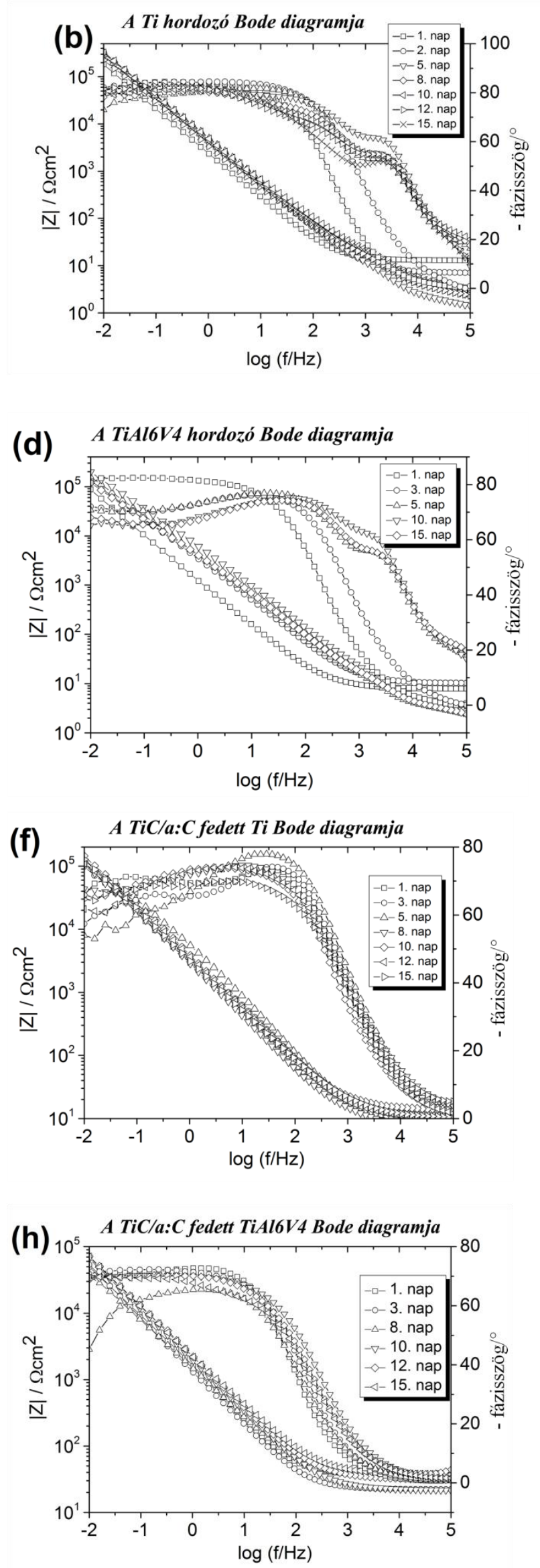

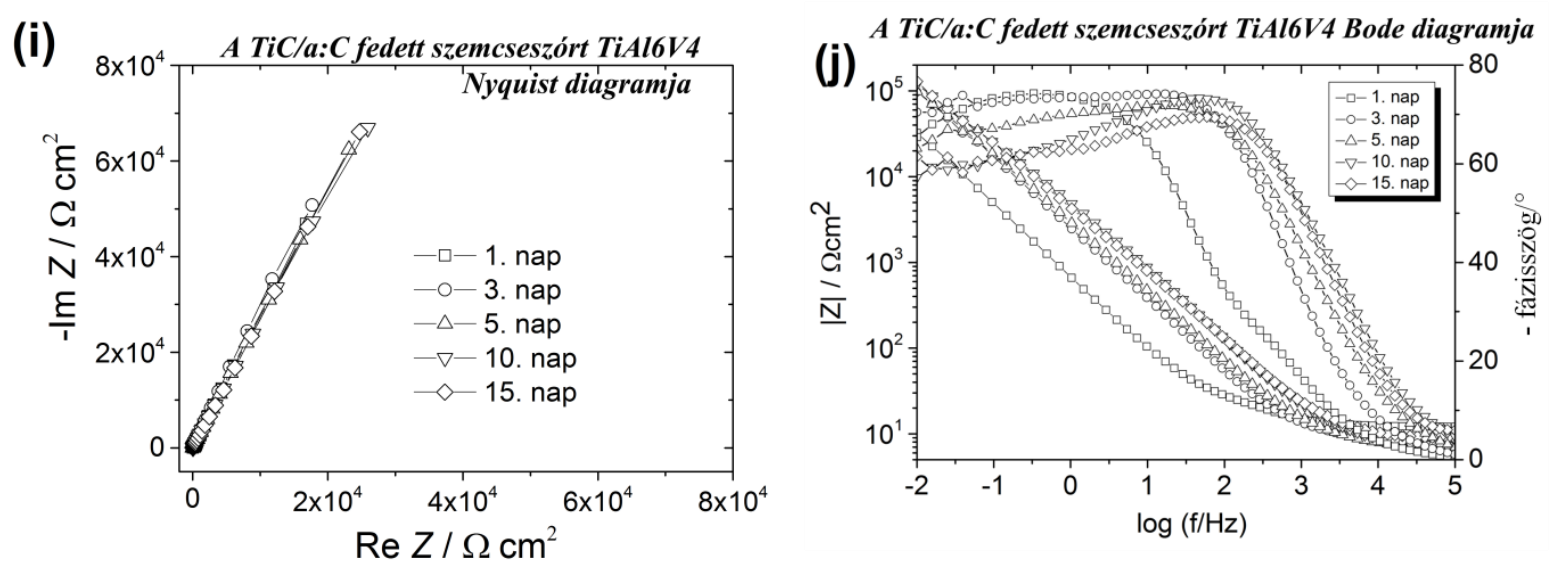

34. ábra: EIS mérések CP Ti hordozón a) Nyquist, b) Bode diagram; TiAl6V4 hordozón c) Nyquist, d) Bode diagram; TiC/a:C fedett Ti e) Nyquist, f) Bode diagram; TiC/a:C fedett TiAl6V4 g) Nyquist, h) Bode diagram és TiC/a:C fedett szemcseszórt felületü TiAl6V4 i) Nyquist és j) Bode diagram.

Az EIS adatok értékelése ebben az esetben is a 30. ábrán látható elektromos helyettesítő áramkörben történt, mely megfelelően tükrözte az elektródák felületén végbemenő folyamatokat. A 34a. és 34c. ábrán megfigyelhető, hogy a tiszta implantátumok komplex síkjai széles ívüek, ami a kapacitív viselkedés jellemzője. Ezt a tulajdonságot az alacsony frekvenciatartományba eső $-80^{\circ}$ fokos fázisszögü értékek is bizonyítják, hasonlóan az első 3 oldatban végzett kísérlethez (28. ábra), valamint [6]. A Ti és TiAl6V4 hordozók Bode diagramja szintén nagyon hasonló, mindkettő két jellegzetes fázismaximumot mutat, amely a nagy és közepes frekvenciatartományban lévő két időállandóra utalhat. A CP Ti összes impedancia értéke valamivel magasabb, mint a TiAl6V4 ötvözeté (34b. és 34d. ábra). A Nyquist ábrák hasonló kapacitív íveket mutatnak a TiC/a:C bevonatú minták esetén, vagyis az ívek kisebbek és jobban a valós tengely felé hajolnak, ami alacsonyabb korrózióállóságukra utalhat (34e. és 34g. ábra). A TiC/a:C bevonatú szemcseszórt felületü TiAl6V4 Nyquist görbéje (34i. ábra) azonban az idővel alig változik, jelezve a többi mintához képest stabilabb és folyamatos korróziós sebességét. A TiC/a:C bevonatú hordozók Bode diagramjai (34f., 34h. és 34j.) három idő-konstans diagramként értelmezhetőek: egy a középfrekvenciás tartományban (ld. a fázisszög maximumát körülbelül $10 \mathrm{~Hz}$-en) és két átfedő időállandó (két egyesülő fázisszög maximális) az alacsony frekvenciatartományban. A fázisszög maximális értéke a TiC/a:C rétegeknél alacsonyabb, mint a fedetlen hordozóknál (minden esetben az idővel $-70^{\circ}$ és $-75^{\circ}$ között változik), hasonlóan a TiN és TiCN 
bevonatokéhoz [21]). A TiC/a:C bevonatok teljes impedancia értékei szintén közel egy nagyságrenddel kisebbek a fedetlen implantátumokéhoz képest (34f., 34h. és 34j. ábra).

Az SBF oldatok fémtartalmának vizsgálatához az elektrokémiai teszteket ICP-OES mérés követte, melynek eredményeit a 6. táblázat mutatja be.

A vanádium ion jelenléte minden esetben érzékelhető, az alumínium és titán ion kimutatási határ alá esett a $\mathrm{TiC} / \mathrm{a}: \mathrm{C}$ réteggel bevont szemcseszórt felületű hordozó esetében. A 6. táblázatban feltüntetett egyéb ionok az SBF oldat összetevőiből (5. táblázat) és más szennyeződésekből származnak. 


\begin{tabular}{|c|c|c|c|c|c|}
\hline $\begin{array}{c}\mu g / l(p p b) / \\
\text { Minták }\end{array}$ & $\begin{array}{c}\text { TiC/a:C fedett } \\
\mathrm{Ti}\end{array}$ & $\begin{array}{c}\text { TiC/a:C fedett } \\
\text { TiAl6V4 }\end{array}$ & $\begin{array}{c}\text { TiC/a:C fedett } \\
\text { szemcseszórt } \\
\text { TiAl6V4 }\end{array}$ & $\begin{array}{c}\text { Ti } \\
\text { hordozó }\end{array}$ & $\begin{array}{l}\text { TiAl6V4 } \\
\text { hordozó }\end{array}$ \\
\hline $\mathrm{Ti}$ & $3,0 \pm 0,15$ & $2,0 \pm 0,1$ & $<$ d.h. $*$ & $<$ d.h. $*$ & $<$ d.h. $*$ \\
\hline $\mathrm{Al}$ & - & $<$ d.h. $*$ & $<$ d.h. $*$ & - & $3,0 \pm 0,15$ \\
\hline V & - & $1,0 \pm 0,1$ & $2,0 \pm 0,1$ & - & $2,0 \pm 0,1$ \\
\hline $\mathrm{Ag}$ & $2,0 \pm 0,1$ & $<$ d.h. $*$ & $11 \pm 1$ & $3,0 \pm 0,15$ & $4,0 \pm 0,2$ \\
\hline $\mathrm{Mn}$ & $2,0 \pm 0,1$ & $1,0 \pm 0,1$ & $7,0 \pm 0,4$ & $7,0 \pm 0,4$ & $9,0 \pm 0,5$ \\
\hline $\mathrm{Cu}$ & $35 \pm 2$ & $27 \pm 1$ & $103 \pm 5$ & $119 \pm 6$ & $155 \pm 8$ \\
\hline $\mathrm{Fe}$ & $1,0 \pm 0,1$ & $3,0 \pm 0,2$ & $1,0 \pm 0,1$ & $14 \pm 1$ & $6,0 \pm 0,3$ \\
\hline $\mathrm{Ni}$ & $62 \pm 3$ & $61 \pm 3$ & $553 \pm 28$ & $343 \pm 17$ & $545 \pm 27$ \\
\hline $\mathrm{Si}$ & $206 \pm 10$ & $211 \pm 11$ & $312 \pm 16$ & $773 \pm 39$ & $566 \pm 28$ \\
\hline $\mathrm{Sr}$ & $18 \pm 1$ & $16 \pm 1$ & $17 \pm 1$ & $552 \pm 28$ & $667 \pm 33$ \\
\hline $\mathrm{Zn}$ & $13 \pm 1$ & $6,0 \pm 0,3$ & $13 \pm 0,7$ & $<$ d.h. * & $40 \pm 2$ \\
\hline \multicolumn{6}{|l|}{$m g / l(p p m)$} \\
\hline K & $296 \pm 6$ & $353 \pm 7$ & $267 \pm 5$ & $290 \pm 6$ & $252 \pm 5$ \\
\hline $\mathrm{P}$ & $47 \pm 1$ & $52 \pm 1$ & $43 \pm 1$ & $48 \pm 1$ & $39 \pm 1$ \\
\hline $\mathrm{S}$ & $22 \pm 0,4$ & $23 \pm 0,5$ & $19 \pm 0,4$ & $26 \pm 1$ & $19 \pm 0,4$ \\
\hline $\mathrm{Mg}$ & $34 \pm 1$ & $37 \pm 1$ & $31 \pm 1$ & $37 \pm 1$ & $31 \pm 1$ \\
\hline $\mathrm{Ca}$ & $73 \pm 1$ & $77 \pm 2$ & $69 \pm 1$ & $51 \pm 1$ & $39 \pm 1$ \\
\hline $\mathrm{Na}$ & $3623 \pm 72$ & $3916 \pm 78$ & $3343 \pm 67$ & $3719 \pm 74$ & $3100 \pm 62$ \\
\hline
\end{tabular}

6. táblázat: Az ICP-OES mérések eredményei. Az SBF oldatban lévö ionok

koncentrációját ppb és ppm mértékegységben határoztuk meg. * d.h. = detektálási határ:

Ti: 0,9 ppb; Al: 1,8 ppb; V: 0,3 ppb; Ag: 1,5 ppb; Zn: 1,0 ppb.

Az illesztési szoftver által megadott ellenállási értékeket a 7. táblázatban foglaltam össze, ahol $\mathrm{R}_{\mathrm{s}}$ minden esetben $10-20 \Omega$ volt. N.T.C. Oliveira és mtsai munkájával ellentétben [6], ahol minden adatot egy egyszerü áramkörrel határoztak meg, ebben a tanulmányban a hordozó anyagokra vonatkozó legjobb illeszkedést egy, a már említett hordozókhoz kapcsolódó kettős $(\mathrm{RC})(\mathrm{RC})$ modell, míg a TiC/a:C réteggel bevont hordozók esetében egy, a hozzájuk kapcsolódó háromszoros $(\mathrm{RC})(\mathrm{RC})(\mathrm{RC})$ áramköri modell adta. $\mathrm{A}$ TiC/a:C bevonatok ellenállásai $\left(\mathrm{R}_{\mathrm{ct}}\right)$ körülbelül egy nagyságrenddel kevesebbnek $\left(10^{4} \Omega\right)$ adódtak a 15 napos bemerítési időt követően, mint a Ti-Mo ötvözetek $\left(10^{5} \Omega\right)$ ellenállásai az 
ő munkájukban [6]. Az értékelt eredmények szerint a töltésátadási ellenállás minden esetben a legmagasabb értéket képviseli, így megállapíthatjuk, hogy az elektródákban fellépő sebességkorlátozó folyamatok az oldódási folyamatokban zajló elektrontranszportnak tudhatók be.

A töltésátadási ellenállásra, mint a korróziós sebesség meghatározó lépésére koncentrálva, a 7. táblázatban láthatjuk, hogy mind a hordozó anyagok, mind a TiC/a:C réteggel bevont szemcseszórt felületü TiAl6V4 hordozó $R_{c t}$ értékei idővel kissé növekvő tendenciát mutatnak. A bevonat nélküli Ti és TiAl6V4 ötvözet hordozók korrózióállósága a felületükön kialakult spontán passzív réteg (oxidréteg) miatt nőtt, másrészt, a csiszolt felületre növesztett TiC/a: $\mathrm{C}$ vékonyrétegek $\mathrm{R}_{\mathrm{ct}}$ értékei meglehetősen csökkenő tendenciát mutatnak a gyengébb korróziós tulajdonságaikra utalva. A potenciodinamikai görbékből számított polarizációs ellenállás értékek az összes minta esetén megfelelnek az EIS mérések által adott töltésátadási ellenállásoknak.

A mérések alapján megállapítottam, hogy a további megfontolás és értékelés szempontjából a TiC/a:C nanokompozit vékonyréteg mint védőbevonat - elsősorban az érdesített felületre növesztve - megfelelö elektrokémiai jellemzőkkel rendelkezik. A durva felületü implantátumok kedveznek a csontkötésnek, valamint biomechanikai stabilitást és jobb tapadást biztosítanak a felületükre felvitt vékonyréteg bevonat, esetünkben TiC/a:C, és a fém eszköz között. 


\begin{tabular}{|c|c|c|c|c|}
\hline Minta & $\begin{array}{l}\text { Idö / } \\
\text { napok }\end{array}$ & $\begin{array}{l}\mathrm{R}_{\text {coat }} / \\
\Omega \cdot \mathrm{cm}^{2}\end{array}$ & $\begin{array}{c}\mathrm{R}_{\mathrm{ct}} l \\
\mathrm{k} \Omega \cdot \mathrm{cm}^{2}\end{array}$ & $\begin{array}{c}\mathrm{R}_{\mathrm{cp}} / \\
\Omega \cdot \mathrm{cm}^{2}\end{array}$ \\
\hline \multirow{5}{*}{ Ti hordozó } & 1 & 1120 & 870 & - \\
\hline & 3 & 1412 & 759 & - \\
\hline & 5 & 1455 & 948 & - \\
\hline & 10 & 2033 & 1016 & - \\
\hline & 15 & 3091 & 997 & - \\
\hline \multirow{5}{*}{$\begin{array}{l}\text { TiAl6V4 } \\
\text { hordozó }\end{array}$} & 1 & 542 & 752 & - \\
\hline & 3 & 618 & 650 & - \\
\hline & 5 & 986 & 722 & - \\
\hline & 10 & 909 & 869 & - \\
\hline & 15 & 818 & 921 & - \\
\hline \multirow{5}{*}{ TiC/a:C/Ti } & 1 & 124 & 16,4 & 69 \\
\hline & 3 & 98 & 17,9 & 45 \\
\hline & 5 & 67 & 15,6 & 58 \\
\hline & 10 & 69 & 15,1 & 52 \\
\hline & 15 & 57 & 14,9 & 64 \\
\hline \multirow{5}{*}{$\begin{array}{l}\text { TiC/a:C/ } \\
\text { TiAl6V4 }\end{array}$} & 1 & 95 & 39,7 & 102 \\
\hline & 3 & 87 & 15,6 & 118 \\
\hline & 5 & 65 & 25,3 & 97 \\
\hline & 10 & 74 & 14,9 & 99 \\
\hline & 15 & 53 & 11,8 & 86 \\
\hline \multirow{5}{*}{$\begin{array}{c}\text { TiC/a:C/ } \\
\text { TiAl6V4 } \\
\text { szemcseszórt }\end{array}$} & 1 & 208 & 12,1 & 42 \\
\hline & 3 & 144 & 10,9 & 39 \\
\hline & 5 & 157 & 11,0 & 35 \\
\hline & 10 & 102 & 12,6 & 36 \\
\hline & 15 & 87 & 12,9 & 23 \\
\hline
\end{tabular}

7. táblázat: $\boldsymbol{R}_{\text {coat, }} \boldsymbol{R}_{c t}$ és $\boldsymbol{R}_{c p}$ ellenállás értékek $37{ }^{\circ} \mathrm{C}$-os SBF oldatban, 2 hetet meghaladó bemerítési idö után.

A bevonat nélküli Ti (a) és TiAl6V4 (b) hordozók korróziós vizsgálatok utáni SEM képeit a 35a. és 35b. ábrán mutatom be, míg a TiC/a:C réteggel bevont minták felületi morfológiáinak változásait a korróziós vizsgálatok után további SEM felvételek (36 - 38 . 
ábra) szemléltetik. A fedett, illetve fedetlen hordozók 26 napon keresztül áztak az oldatban és a különböző méretű minták eltérő elrendezésben, de azonos nagyságú felülettel merültek az elektrolitba. A korrodálódott-, illetve az ép felszínek minél látványosabb bemutatására törekedve, a képek különböző nagyításoknál, más-más skálával készültek.
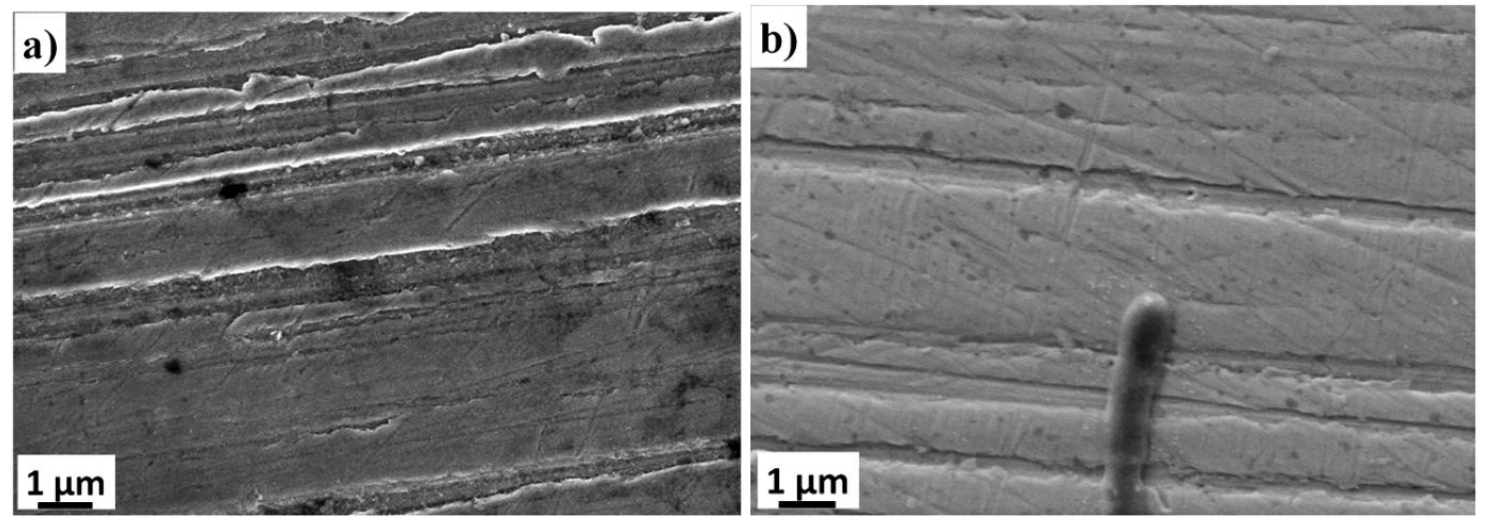

35. ábra: SEM képek a bevonat nélküli Ti (a) és TiAl6V4 (b) hordozókról az SBFben tesztelt korróziós vizsgálatok után.
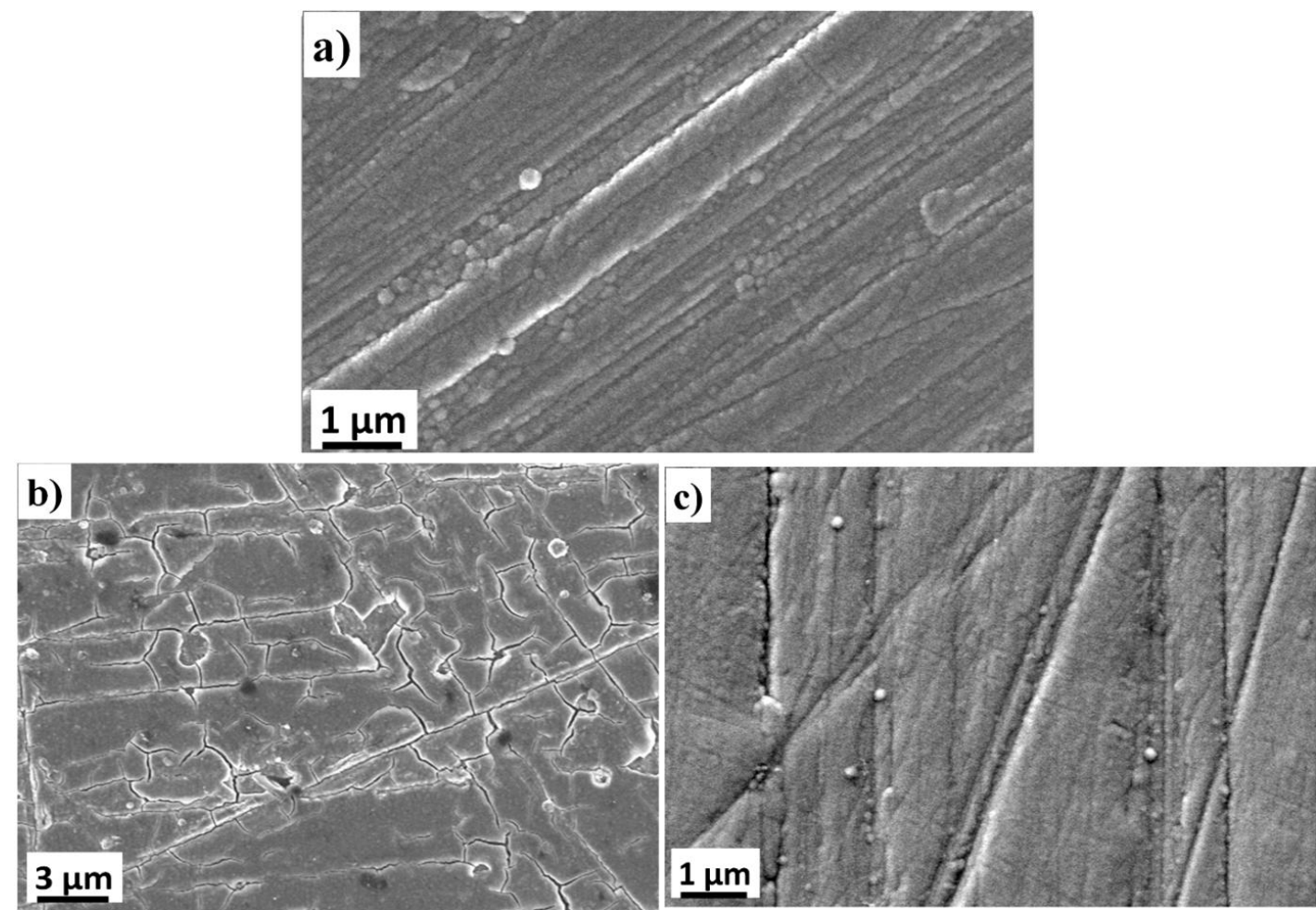

36. ábra: Korróziós tesztek SEM felvételei; a) TiC/a:C/Ti a korróziós vizsgálatok elött, b) TiC/a:C bevonattal ellátott Ti az SBF-ben végzett vizsgálatok után és c) TiC/a:C/Ti SBF-ben áztatás után. 

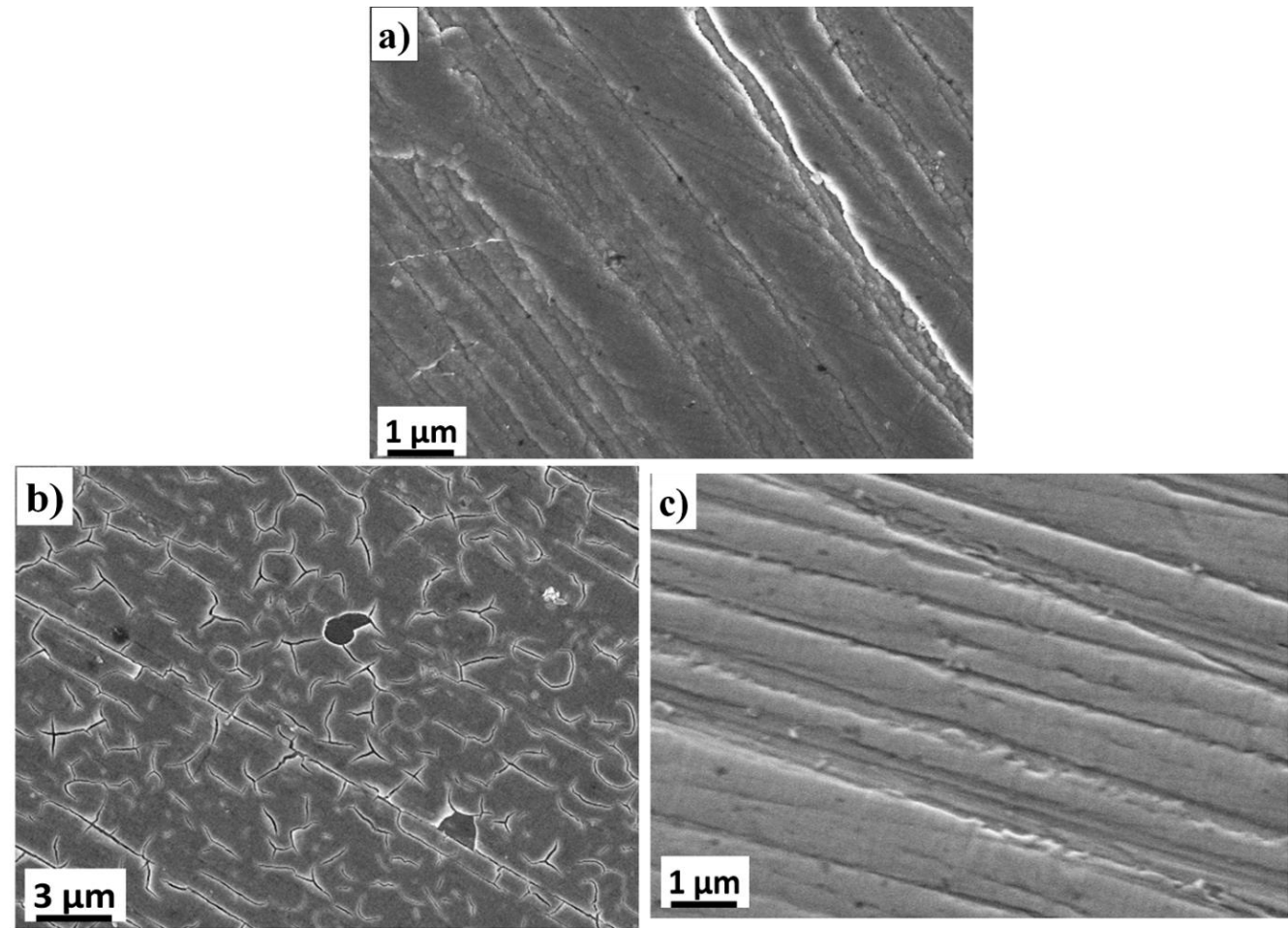

37. ábra: Korróziós tesztek SEM felvételei; a) TiC/a:C/TiAl6V4 a korróziós vizsgálatok elött, b) TiC/a:C bevonattal ellátott TiAl6V4 az SBF-ben végzett vizsgálatok után és c) TiC/a:C/TiAl6V4 SBF-ben áztatás után.
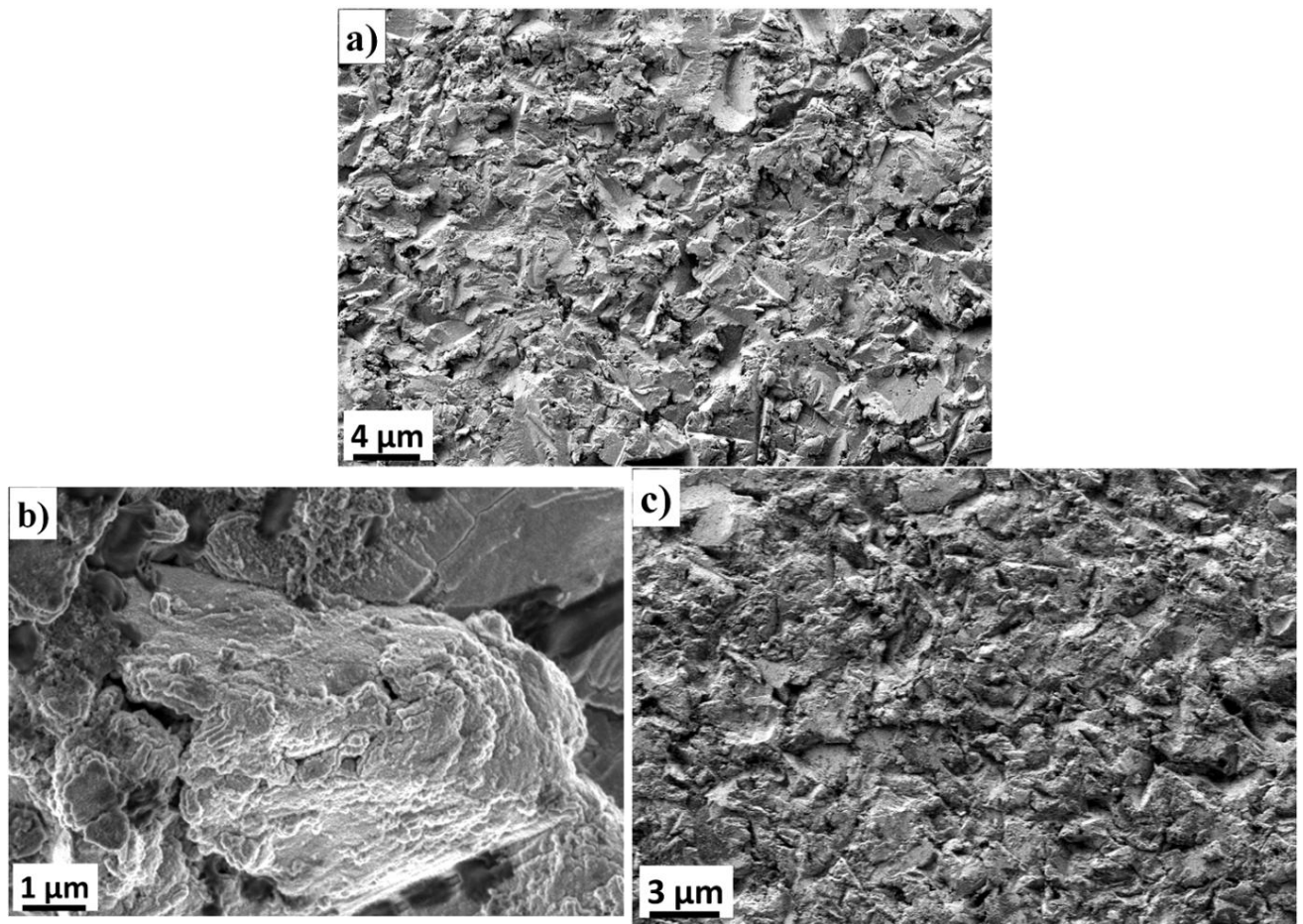

38. ábra: Korróziós tesztek SEM felvételei; a) TiC/a:C/szemcseszórt TiAl6V4 a korróziós vizsgálatok elött, b), c) TiC/a:C bevonattal ellátott szemcseszórt TiAl6V4 az SBFben végzett vizsgálatok után. 
Az ábrákon jól látható, hogy a minták mindegyike bizonyos mértékig korrodálódott, azonban a korrózió mértéke mintánként eltérő. A fedetlen hordozók (35. ábra), valamint a TiC/a:C bevonatos szemcseszórt TiAl6V4 (38. ábra) hordozó felületén semmiféle különleges morfológiai változás nem tapasztalható az elektrokémiai teszteket követően. A 36b. és 37b. ábrán bemutatott képek az elektrokémiai vizsgálatoknak kitett felületröl készültek, a TiC/a:C bevonattal ellátott csiszolt Ti és TiAl6V4 ötvözet anyagok rongálódása ugyanazt a hatást mutatja. A minták másik oldala (36c. és 37c. ábra), mely kizárólag csak ázott az SBF oldatban 26 napon keresztül, nem mutat különösebb elváltozást. A SEM analízisek során a bevont, csiszolt Ti és TiAl6V4 felületeken kisebb hibákat regisztráltunk (36b. és 37b. ábra), míg a bevonat nélküli (35a. és 35b. ábra) és TiC/a:C bevonatos szemcseszórt TiAl6V4 (38b. ábra) felületek hibamentes morfológiát mutattak. Mérésekkel igazoltam, hogy korróziós tulajdonságok tekintetében a morfológiailag legmegfelelőbb TiC/a:C vékonyréteg a szemcseszórt felületü TiAl6V4 hordozóra növesztett réteg volt (38. ábra).

\subsubsection{Következtetés}

A korróziós vizsgálatok legfontosabb eredménye, hogy a különböző hordozókra porlasztott TiC/a:C védőbevonatok, miközben nagy keménységet biztosítanak a felületnek, az elektrokémiai folyamatoknak is ellenállnak. Általánosan elmondható, hogy a korróziós áram $\left(\mathrm{j}_{\text {korr. }}\right)$ fordítottan arányos a korróziós ellenállással $\left(\mathrm{R}_{\mathrm{p}}\right)$. Ezt bizonyítandó a 39. ábrán összefoglaltam a $\mathrm{TiC} / \mathrm{a}: \mathrm{C}$ réteggel fedett, valamint a bevonat nélküli implantátum anyagok potenciodinamikai görbéiböl származtatható $E_{\text {korr. }}$ (a) $j_{\text {korr. }}$ (b) és $R_{p}$ (c) értékeket.

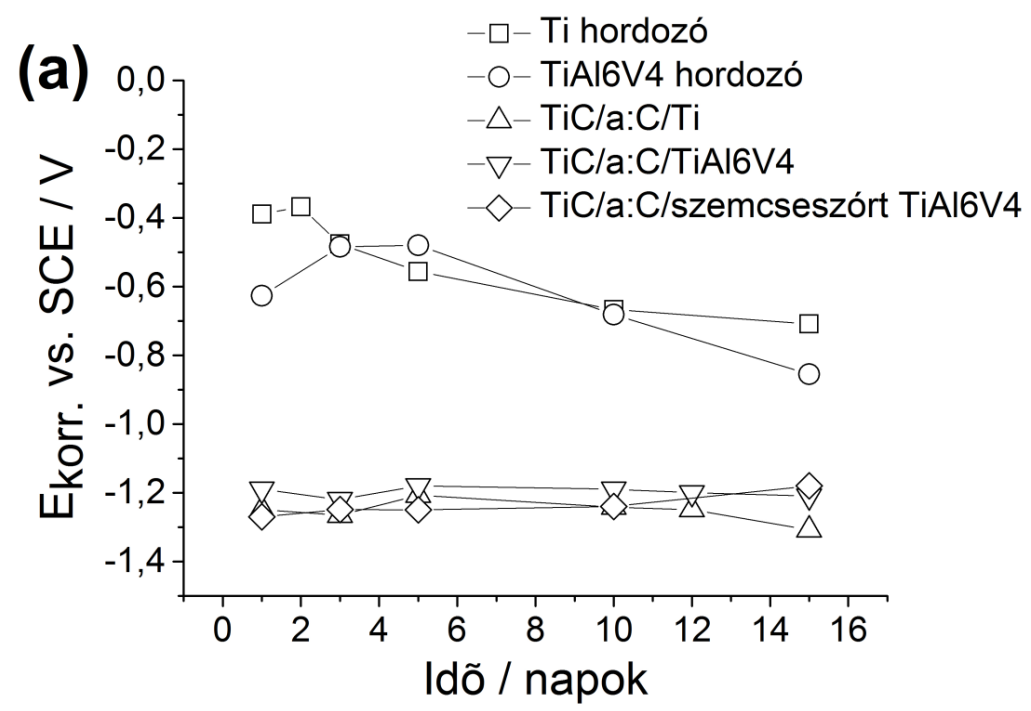



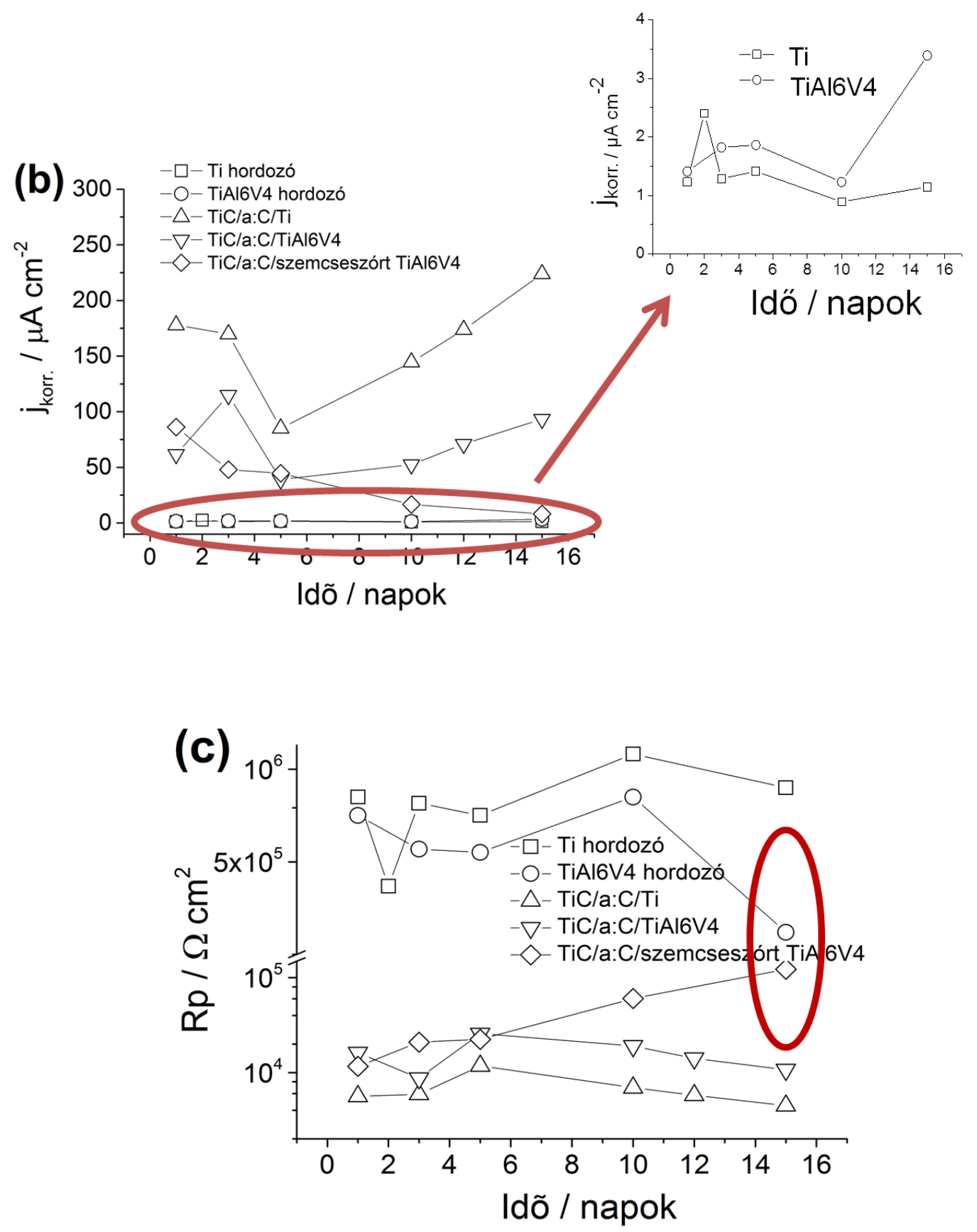

39. ábra: A TiC/a:C réteggel fedett, valamint a bevonat nélküli implantátum anyagoknak a 33. ábrán bemutatott potenciodinamikai görbéiböl származtatható $E_{k o r r . ~}(a)$ $j_{\text {korr. }}$ (b) és $R_{p}$ (c) értékei.

A potenciodinamikai görbék értékeléséböl megállapítható, hogy

- az alapfémek korróziós potenciálja $\left(\mathrm{E}_{\mathrm{korr}}\right)$ minden esetben pozitívabb, mint a TiC/a:C vékonyrétegeké (39a. ábra), valamint

- a réteggel fedett hordozók korróziós áramsürüség értékei egy nagyságrenddel nagyobbak; 
- a fedetlen implantátumok korróziós áramsürüsége alacsony, 1 és 3,5 $\mu \mathrm{A}$ között mozog és az idő múlásával alig változik (lásd a 39b. ábra nagyítását).

Kimutattam, hogy hosszútávon az alapfémek stabilak, bár 10 napos bemerítési időt követően $j_{\text {korr. }}$ értékeik növekedni kezdenek $R_{p}$ értékeik csökkenésével egyidejüleg, miközben a TiC/a:C bevonatú szemcseszórt TiAl6V4 mindkét esetben jobb eredményt mutat (39b. és 39c. ábra). Másrészt, a TiC/a:C bevonatos szemcseszórt TiAl6V4 ötvözet kivételével, a TiC/a:C vékonyrétegek minden esetben magasabb $\mathrm{j}_{\text {korr. }}$ értékekkel rendelkeznek, és öt napos bemerítési idő után kissé növekvő tendenciát mutatnak. A réteggel fedett, szemcseszórt felületü hordozó $j_{\text {korr. }}$ értékének csökkenése, illetve a rétegek közötti legjobb értéke is azt bizonyítja, hogy a homokfúvással végzett felületi érdesítés növelheti a korrózióállóságot.

Mindezek következtében a legmagasabb polarizációs ellenállásokkal a bemerítési idő múlásával a TiC/a:C bevonattal ellátott, homokfúvott TiAl6V4 ötvözet rendelkezik, míg a legalacsonyabb ellenállások a $\mathrm{TiC} / \mathrm{a}: \mathrm{C}$ bevonattal ellátott csiszolt hordozókhoz tartoznak (39c. ábra). Utóbbi jelenség azzal magyarázható, hogy a $\mathrm{TiO}_{2}$ passzív film sokkal sérülékenyebb [82] a hosszabb idejü korróziós körülményeknek kitéve, mint a TiC/a:C védőbevonat. Másodszor, az ICP-OES eredményekből kiderült, hogy a TiC/a:C bevonattal ellátott, homokszórt TiAl6V4 ötvözet megakadályozza a Ti és Al SBF-be történő beoldódását. Összességében az érdesitett felületre felvitt TiC/a:C vékonyréteg megfelelö elektrokémiai jellemzőkkel rendelkezik védö bevonatként való további vizsgálatokhoz, értékeléshez.

\section{Kitekintés a jövőre}

Kísérleteim folytatásaként a jövőben a rétegek in vitro és in vivo vizsgálataira szeretnék nagyobb hangsúlyt fektetni. A porlasztott rétegeket már alávetettük biokompatibilitás és hidrofilitás vizsgálatoknak, melyek eredményeit azonban még teljes egészében nem értékeltük ki és nem publikáltuk. Elöljáróban azonban ismertetnék egy-két lényeges megállapítást, melyből a legfontosabbat a 40. ábra is szemlélteti. A rétegek felületét összehasonlítva a biokompatibilitás és életképességi vizsgálatok referencia anyagaival (mikroszkópos üveg fedőlemez és standard polisztirolos sejttenyésztő edény; PS) látható, hogy a sejtek leginkább a TiC/a:C vékonyréteg felületén szaporodtak el. A 40. ábrából arra is következtethetünk, hogy a rétegek nem toxikusak, vagyis biokompatibilisek és a sejtek életképessége 3 nap elteltével is kiváló. Ezen kívül, a bevonatokon végzett hidrofilitás 
vizsgálatok eredményeiből megállapítottuk, hogy minden összetételnél elöállitott réteg hidrofób viselkedést mutat.

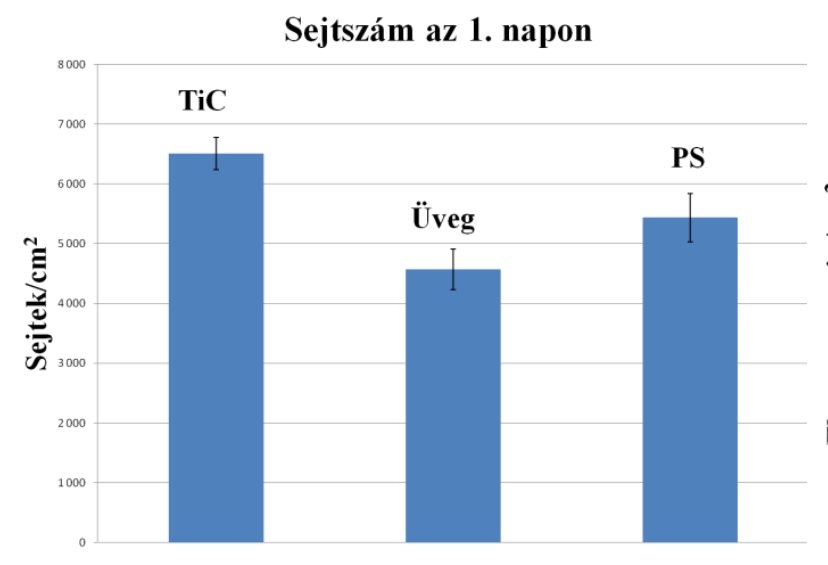

Sejtszám a 14. napon

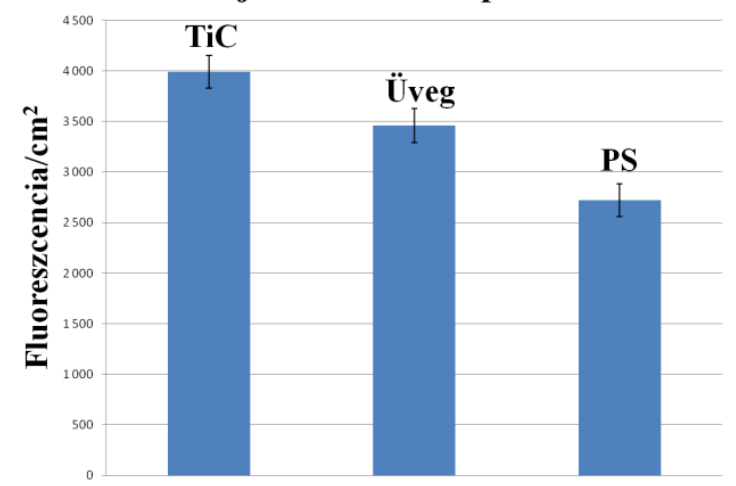

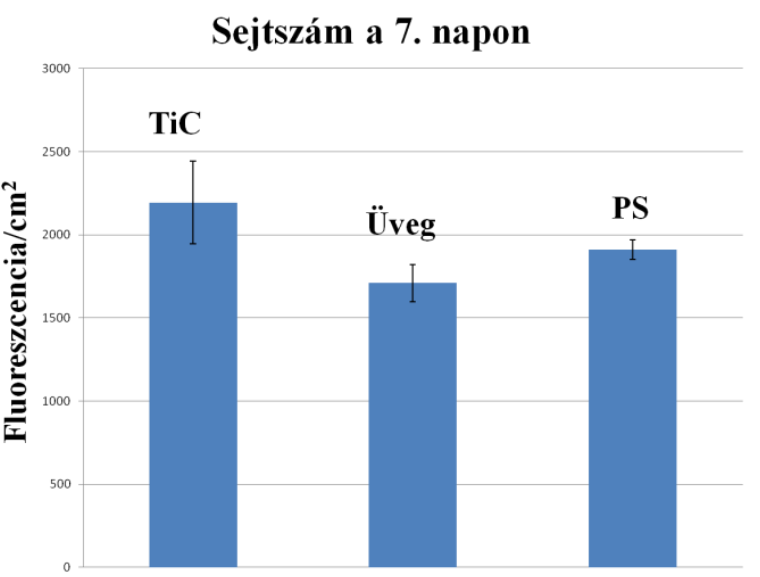

Életképesség a 3. napon

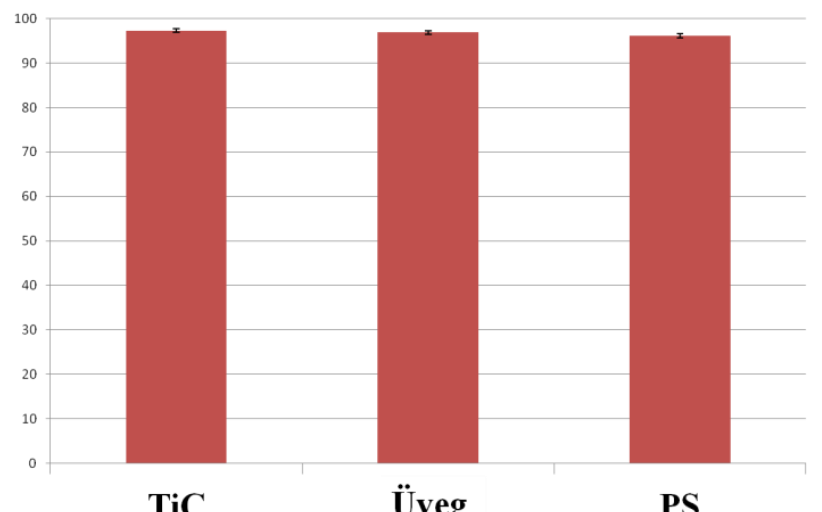

40. ábra: MG-63 humán csontsejtek biokompatibilitás (1, 7 és 14 napos tenyésztés után) és életképességi (3 napos tenyésztés után) vizsgálata TiC/a:C vékonyrétegeken, mikroszkópos üveg fedölemezeken (üveg) és standard polisztirolos sejttenyésztő edényekben (PS).

A rétegek optimális adhéziójának érdekében a szemcseszórás mellett, különböző felületkezelési eljárásokat is alkalmaztam a fém hordozók esetében, mint a Ti köztes réteg a hordozó és a TiC/a:C nanokompozit között, hőkezelés $600^{\circ} \mathrm{C}$-on, tisztítás plazmával oxigén gázban és - $100 \mathrm{~V}$ elöfeszítés rákapcsolása a hordozó anyagára. Az előállított rétegek adhéziós vizsgálatát karc teszttel végeztük, ugyanazzal a nanoindentációs berendezéssel, mint a nanokeménység méréseket. A 8 legjobb felületü mintát mértük meg, mindegyiken 4 karcot késztettünk $500 \mu \mathrm{m}$ hosszan, maximum $150 \mathrm{mN}$-ig növekvő erővel. A szemcseszórt felületü mintákon a tesztnek a felületi durvaság miatt nem volt értelme, de egyébként is maga a szemcseszórás is a jobb tapadás érdekében történt. Egyik mintán sem tapasztaltunk 
semmilyen karakterisztikus ugrást, kivéve talán az 1. mintát, de delamináció összességében alig tapasztalható. Ezt támasztják alá a 41. ábrán a karc teszteket követően konfokális mikroszkóppal a minták felületéről készített felvételek is.

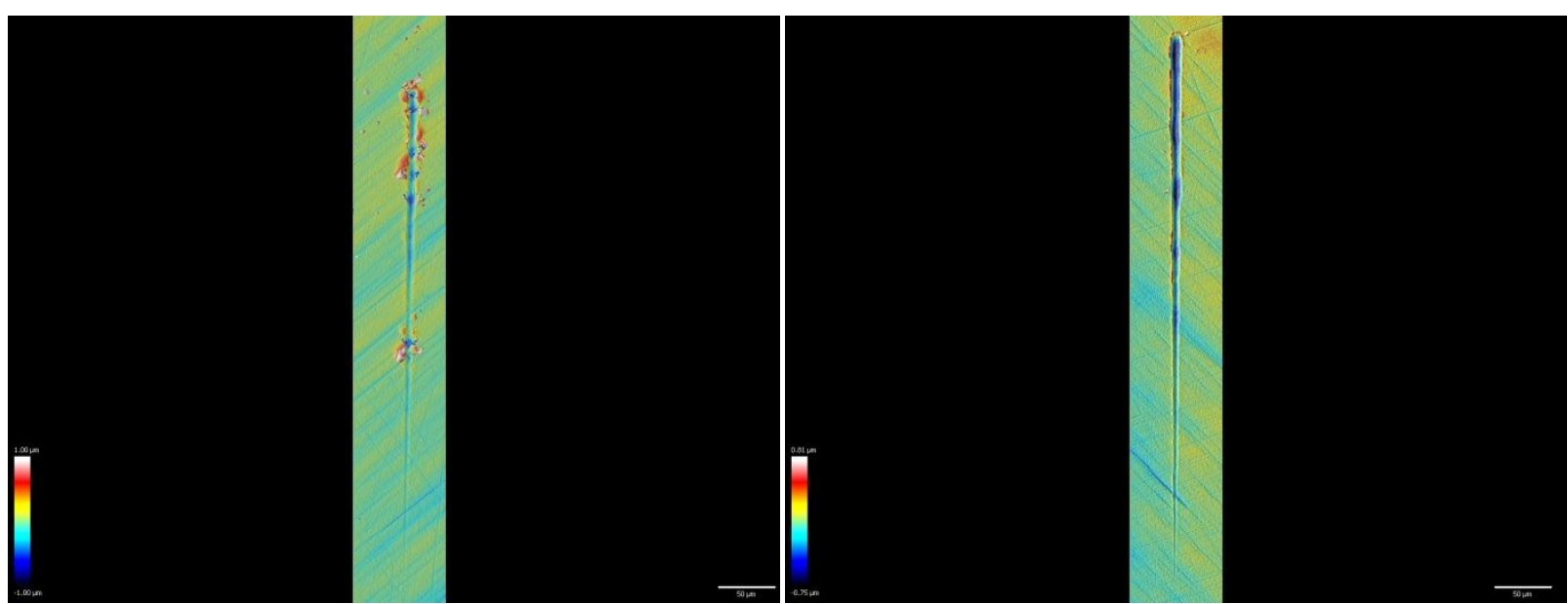

1. TiC/a:C_Ti köztesréteg_TiAl6V4 hordozó

2. TiAl6V4 alapfém
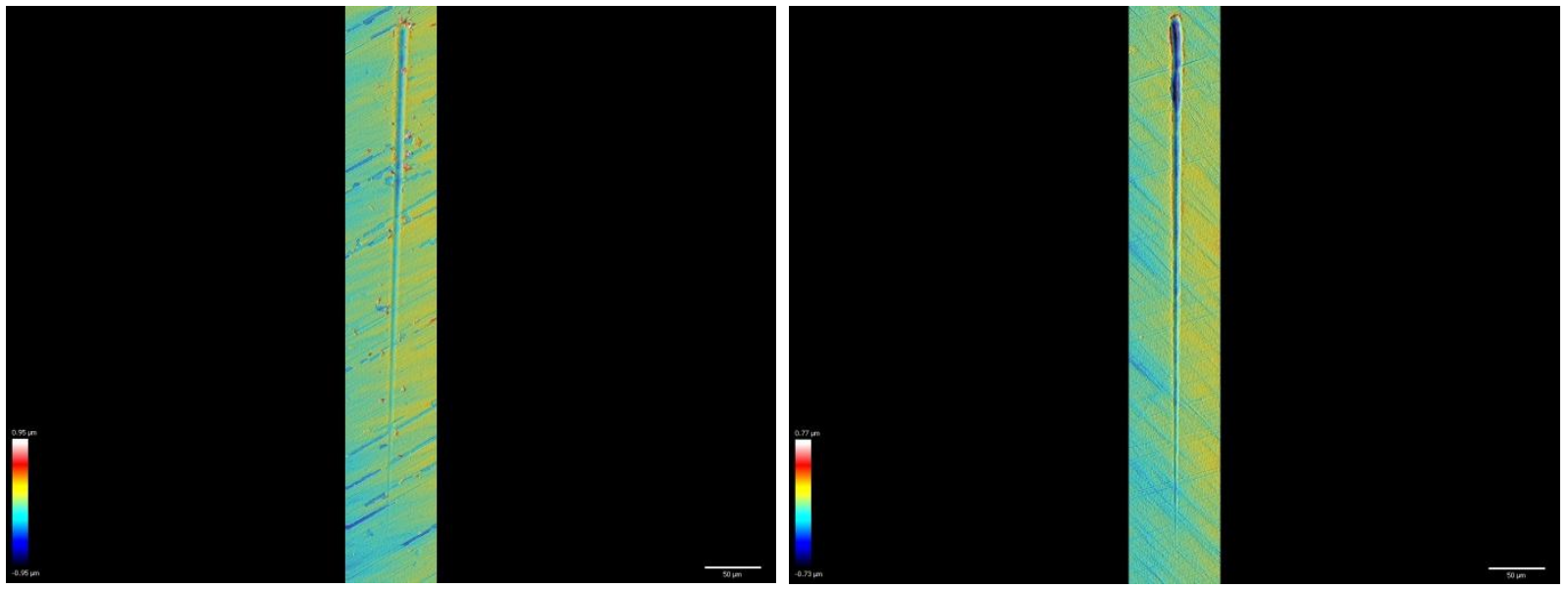

3. TiC/a:C_TiAl6V4 hordozó; - $100 \mathrm{~V}$

4. TiC/a:C_TiAl6V4 hordozó (elözetes

elöfeszités tisztítás plazmával oxigén gázban)

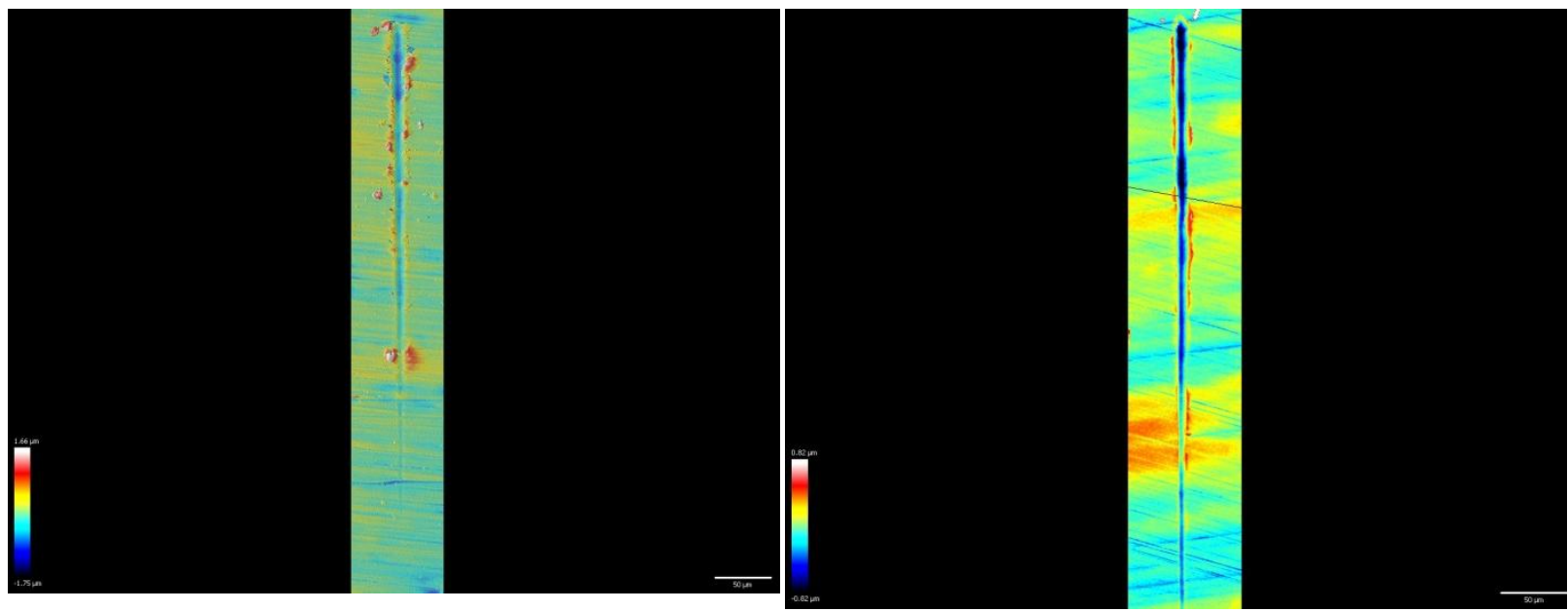




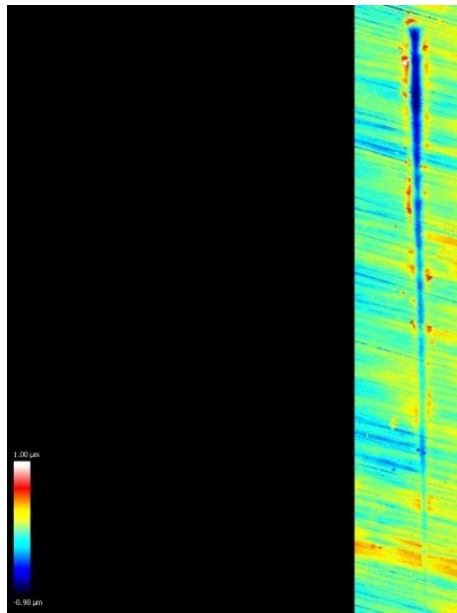

7. TiC/a:C_Ti hordozó (elözetes tisztitás plazmával oxigén gázban)
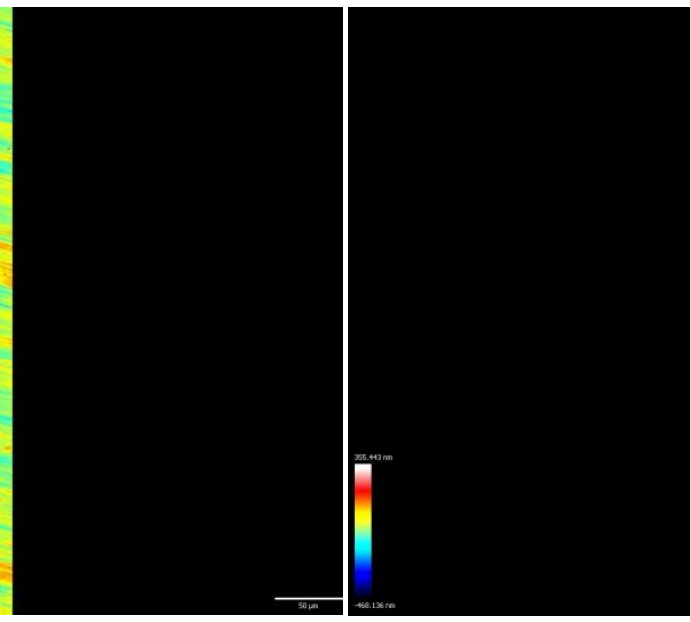

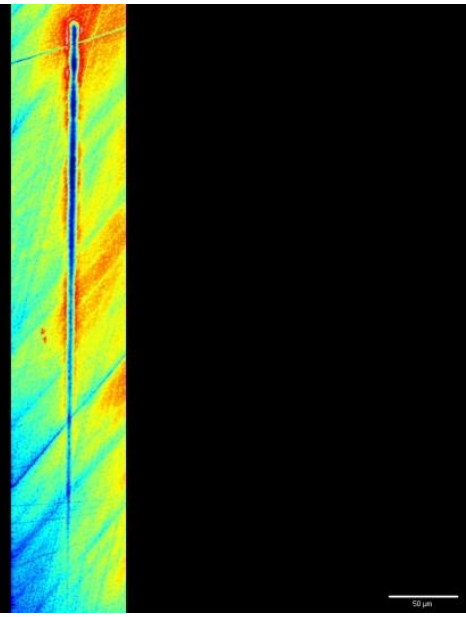

8. TiC/a:C_Ti hordozó; elözetes hökezelés $600^{\circ} \mathrm{C}$-on

\section{1. ábra: A különböző felületkezelési eljárásoknak alávetett hordozók és a rájuk} porlasztott TiC/a:C vékonyrétegek konfokális mikroszkópos felvételei az adhéziós teszteket követöen.

Megjegyezném, hogy a 41. ábrán látható elözetesen plazmával tisztított TiC/a:C/TiAl6V4 (4.) és TiC/a:C/Ti (7.) minta az adhéziós vizsgálatokat megelőzően az SBF-ben végzett korróziós vizsgálatoknak volt kitéve. A mérések pontos kiértékelése, a minták szerkezetének vizsgálata és az eredmények publikálása a későbbiekben fog megtörténni.

Összevetve azonban az imént bemutatott adhéziós eredményeket a korróziós vizsgálatok után végzett SEM felvételekkel elmondható, hogy a rétegek minden esetben az alapfém hordozókon maradtak függetlenül a rajtuk elvégzett, vagy el nem végzett felületkezelési eljárásoktól.

Munkám eredményei alapján kimutattam, hogy a TiC/a:C nanokompozit vékonyréteget, mint lehetséges fiziológiai implantátum védöbevonatot mindenképpen érdemes tovább vizsgálni, és megfontolni a dolgozatban ismertetett viszonylag olcsó, egyszerü és reprodukálható elöállitási és minősitő módszerek alkalmazását, valamint ipari méretüvé fejlesztését. 


\section{7. ÖSSZEFOGLALÁS}

A fémből készült orvosi implantátumok nagy részét kedvező biokompatibilitása miatt titánból vagy különböző ötvözeteiből készítik. A titánnak többek között kiváló kémiai, fizikai és mechanikai tulajdonságai vannak. A beültetést követően azonban - korrózió vagy fémleválások miatt - titánionokat (és/vagy ötvöző elemeket) lehet kimutatni a szervezetben, melyek gyulladást okozhatnak, allergiás tünetekhez vezethetnek, s legrosszabb esetben az implantátum eltávolítása válhat szükségessé. Annak érdekében, hogy elkerüljük az ionok kioldódását, növeljük a fém korrózióállóságát, valamint biokompatibilitását, többféle módszert is lehet alkalmazni, melyek közül az egyik lehetséges a felület passziválása nanokompozit anyagokkal. Disszertációmban ilyen, titánkarbid (TiC) / amorf szén (a:C) nanokompozit vékonyréteg passziváló, korrózióállóságot és biokompatibilitást növelő bevonat alkalmazásáról számoltam be.

Dolgozatom fö célja a TiC/a:C nanokompozit vékonyréteg bevonatok fejlesztése, előállítása magnetronos porlasztással, növekedési mechanizmusának elektronmikroszkópos vizsgálata, a kialakuló szerkezet és a fizikai - biológiai tulajdonságok közötti kapcsolatok meghatározása, valamint az ezekhez szükséges mintaelőkészítés és mintapreparáció volt, elsősorban orvosi implantátumok felületi tulajdonságainak javításának céljából. Ezen felül kutató tevékenységem az anyagtudomány különböző területeire is kiterjed. A TiC/a:C rétegeket széles körben alkalmazzák, nemcsak orvosi, de ipari, mérnöki felhasználásokra is: vágó szerszámok bevonata, erősítő fázis fém mátrix kompozitokban, ür-, és légi alkalmazások, diffúziós gát a félvezető technológiában és az implantológiában, katalizátor a platina alternatívájaként, mikroelektronikai eszközök fejlesztése, mátrix belső vezetőképességének javítása az atomenergia-iparban.

Vizsgálataim során a TiC/a:C nanokompozit vékonyrétegek előállítása minden esetben egyenáramú (DC) magnetronos porlasztással, szobahőmérsékleten, 2,5 x 10 $0^{-3} \mathrm{mbar}$ argon (Ar) háttérgázban történt. A felhasznált hordozók $\mathrm{SiO}_{2} / \mathrm{Si}$, kereskedelmi tisztaságú $(\mathrm{CP})$ titán, sima illetve szemcseszórt felületü TiA16V4 ötvözet, valamint szemcseszórt felületü CoCrMo ötvözet implantátum anyagok voltak. Ti és C céltárgyak egyszerre történő porlasztásával, különböző teljesítményeinek beállításával, az idő függvényében különböző összetételü nanokompozitokat hoztam létre. A kísérletek során a C céltárgy teljesítménye állandó volt $(150 \mathrm{~W})$, míg a titán céltárgy teljesítményét 5 és $150 \mathrm{~W}$ között változtattam. A porlódási sebesség, valamint a $\mathrm{Ti}$ és $\mathrm{C}$ sürüségének megállapítására egy $\mathrm{C} / \mathrm{Ti} / \mathrm{C} / \mathrm{Ti} / \mathrm{C} / \mathrm{Ti}$ 
multiréteget is készítettem mellyel bizonyítottam, hogy a leválasztott réteg vastagsága minden esetben arányos a porlasztási teljesítménnyel és a porlasztási idővel. Ha a porlasztás folyamán nem áll rendelkezésre rétegvastagság mérési lehetőség, az alkotók egyéni porlódási sebességének ismeretében tehát közelítő becslést kaphatunk a nanokomopozit réteg időarányos vastagságáról.

Megmutattam, hogy az egyenáramú magnetronos porlasztással szobahőmérsékleten elöállított TiC/a:C vékonyrétegek szerkezetváltozásai követték a kétkomponensü rendszer zónadiagram modelljét, a makroszkopikus Ti - C fázisdiagram alapján 47 at\% titántartalom felett várt fázisátalakulásokat viszont nem tapasztaltam és a szén végig amorf állapotban maradt. A szerkezeti vizsgálatok alapján megállapítottam, hogy kezdetben nagyjából 41 at\% Ti tartalomig globuláris TiC nanokristályok jelennek meg, 41 at\%-tól a leválasztott rétegekben oszlopos növekedés figyelhető meg. Az oszlopok átmérője a Ti teljesítmény növelésével, és ennek következtében a Ti mennyiségének növekedésével kiszélesedik. A nagyobb Ti tartalommal ez a kiszélesedés felgyorsul. A Ti tartalom megnövekedésével az amorf szén mátrix vastagsága 10 nm-ről 1 - 2 nm-re csökken, miközben a nanokristályok kb. 0,5 nm-es méretről 26 nm-es nagyságúra növekednek. Az FFT bizonyította, hogy a leválasztott rétegekben egyfajta, lapcentrált köbös (fcc) kristályfázisú TiC jelenik meg. A Ti tartalom további növelésével, egészen 60 at\%-ig a teljes réteghosszúságú TiC oszlopok közül eltünik az amorf szén és az fcc TiC fázison kívül egyéb Ti tartalmú fázis, mint pl. hcp-Ti, nem alakul ki.

Munkámban elemeztem a TiC/a:C vékonyrétegek szerkezetének mechanikai tulajdonságokra gyakorolt hatását is és kimutattam, hogy a mechanikai (keménység $(\mathrm{H})$, rugalmasság (E)) és tribológiai tulajdonságai erőteljes változatosságot mutatnak a Ti tartalom függvényében. A 34 és 41 at\% közötti Ti tartalom esetén lesznek a $H$ és E értékek maximálisak. Ebben a szerkezetben a $8-16$ nm vastagságú TiC szemcsék $2-3 \mathrm{~nm}$ vékony, amorf mátrixba ágyazódnak. A mechanikai tulajdonságok szempontjából, implantátumok bevonataként ezek a leginkább megfelelő rétegek. A réteg segítségével az alapfémek keménységét $\mathrm{kb}$. négyszeresére növeltem, míg súrlódási együtthatóját negyedére csökkentettem vagyis a szerkezetileg legjobb rétegben (38 at\% Ti tartalom) a keménység 26 GPa egy 0,268-as súrlódási együtthatóval. Az XPS mérések alapján, a különböző hordozókra, különböző vastagsággal porlasztott rétegek koncentrációinak hibahatáron belüli jó korrelációját figyeltem meg. A $\mathrm{P}_{\mathrm{Ti}}=40 \mathrm{~W}$ (négy különböző réteg) és a $\mathrm{P}_{\mathrm{Ti}}=50 \mathrm{~W}$ (három különböző réteg) DC magnetronos porlasztással készült bevonatok vizsgálatai alapján a TiC/a:C nanokompozit vékonyrétegek bizonyítottan reprodukálhatóak, elemi összetételük a 
céltárgyak porlasztási teljesítményének függvényében változik, ugyanakkor nem függ sem az alkalmazott hordozótól, sem pedig a réteg vastagságától.

A korróziós vizsgálatok legfontosabb eredménye, hogy a különböző hordozókra porlasztott TiC/a:C védöbevonatok, miközben nagy keménységet biztosítanak a felületnek, az elektrokémiai folyamatoknak is ellenállnak. A mérések alapján legmagasabb polarizációs ellenállásokkal a bemerítési idő múlásával a TiC/a:C védőbevonattal ellátott, érdesített felületü TiAl6V4 ötvözet rendelkezett, míg a legalacsonyabb ellenállások a bevonattal ellátott csiszolt hordozókhoz tartoznak. Az ICP-OES eredményekből ugyanakkor az is kiderült, hogy a homokszórt felületre felvitt réteg megakadályozza a Ti és Al szimulált testnedv folyadékba történő beoldódását.

A rétegek felületének biokompatibilitás és életképességi vizsgálatai alapján elmondható, hogy a sejtek a TiC/a:C bevonat felületén elszaporodtak, vagyis a rétegek nem toxikusak, biokompatibilisek és a sejtek életképessége 3 nap elteltével is kiváló. A bevonatokon végzett hidrofilitás vizsgálatok eredményéből ugyanakkor megállapítottuk, hogy minden összetételnél előállított réteg hidrofób viselkedést mutat.

\section{SUMMARY}

Most of the metal medical implants are made from titanium (Ti) or their various alloys because of their favorable biocompatibility. However, after implantation, Ti ions (and / or alloying elements) can be detected in the organism - due to corrosion or metal scraping which may cause inflammation, may lead to allergic symptoms, and in the worst case, the implant must be removed. In order to increase the metal insulation, corrosion resistance, and thus biocompatibility, several methods can be used. One of them is the passivation of the surface with different nanocomposites. In my dissertation, I have written about the use of a such like passivating, corrosion resistance and biocompatible titanium carbide (TiC) / amorphous carbon $(\mathrm{a}: \mathrm{C})$ coating.

The main goal of my dissertation is to develop TiC/a:C nanocomposite thin film coatings by DC magnetron sputtering to improve the surface properties of medical implants, the electron microscopic examination of their growth mechanism, determination of the relationships between the sample preparation, as well as the structure and the physical biological properties. In addition, my research activity covers various fields of materials science. TiC/a:C thin films are widely used, not just for medical but also for industrial and 
engineering applications: hard coating material for cutting tools, reinforcing phase in metal matrix composites, space and air applications, diffusion barrier in semiconductor technology and implantology, an alternate to platinum as a catalyst, development of microelectronic devices and as a second dispersive phase in nuclear power industry to improve the intrinsic conductivity of the matrix.

During my examinations, the TiC/a:C coatings with different structures were developed by simultaneous deposition of $\mathrm{Ti}$ and $\mathrm{C}$ on $\mathrm{SiO}_{2} / \mathrm{Si}$, commercially pure (CP) titanium, a smooth (unblasted) and sandblasted TiAl6V4 alloy and sandblasted CoCrMo alloy implant material using DC magnetron sputtering system in argon (2.5 x $10^{-3}$ mbar) background gas at room temperature. The thin films were examined depending on the increasing titanium target power $(5-150 \mathrm{~W})$ at fixed carbon target power $(150 \mathrm{~W})$. In order to determine the deposition rate and the density of $\mathrm{Ti}$ and $\mathrm{C}$, a $\mathrm{C} / \mathrm{Ti} / \mathrm{C} / \mathrm{Ti} / \mathrm{C} / \mathrm{Ti}$ multilayer was also prepared. The thickness of the deposited thin film is proportional to the sputtering power and the sputtering time in each case was proved by the multilayer. If there is no available layer thickness measurement during sputtering process, it is possible to obtain an approximate estimate of the nanocomposite thin film time proportional thickness in the knowledge of the individual deposition rate of the components.

It was shown that the $\mathrm{TiC} / \mathrm{a}: \mathrm{C}$ thin films produced by $\mathrm{DC}$ magnetron sputtering at room temperature follow the morphology characteristic of the two - component system zone diagram, but any phase transformations over the titanium content of 47 at $\%$ based on the macroscopic $\mathrm{Ti}$ - $\mathrm{C}$ phase diagram was not seen, the carbon phase remained in the amorphous state. Based on the structural examinations it was found that the globular TiC nanocrystals began to take shape until 41 at\% of Ti content and above this amount, the films were grown by columnar crystals. The diameter of the columns broadens with increasing power of $\mathrm{Ti}$ target and with the higher Ti contents this broadening faster. As the Ti content increased, the thickness of the amorphous carbon matrix decreased from $10 \mathrm{~nm}$ to $1-2 \mathrm{~nm}$ and the size of the TiC nanocrystals grew from $0.5 \mathrm{~nm}$ to $26 \mathrm{~nm}$. FFT confirmed the presence of the only identifiable face centered cubic (fcc) TiC crystal phase. The further increasing of Ti content, till 60 at\% showed the disappearance of amorphous carbon from the fully length TiC columns and any other Ti containing phase, such as hcp Ti, was not developed.

In my work, the effect of TiC/a:C thin films on the mechanical (hardness $(\mathrm{H})$, modulus of elasticity (E)) and tribological properties was also analyzed and it was demonstrated that these properties shows a distinct variation depending on $\mathrm{Ti}$ content. The $\mathrm{Ti}$ content between 34 and 41 at\% yields to TiC grains of $8-16 \mathrm{~nm}$ embedded in $2-3 \mathrm{~nm}$ thin 
amorphous matrix provides the maximal $\mathrm{H}$ and $\mathrm{E}$. These are the most suitable compositions in terms of the mechanical properties. The hardness and the tribological properties of the bare implant materials are improving by four times with the $\mathrm{TiC} / \mathrm{a}: \mathrm{C}$ nanocomposite coating beside a moderate elastic modulus value. The highest $\mathrm{H}$ of $26 \mathrm{GPa}$ with friction coefficient of 0.268 was observed in case of the film prepared at 38 at\% Ti content. Based on the XPS analysis was carried out on TiC/a:C thin films on different substrates with different thicknesses a good correlation between their concentration was observed within a margin of error. Thin films prepared at $40 \mathrm{~W} \mathrm{P}_{\mathrm{Ti}}$ (four different layers) and between the thin films deposited at $50 \mathrm{~W} \mathrm{P}_{\mathrm{Ti}}$ (three different layers) have been shown to be reproducible; their elemental composition does not depend on the layer's thickness or the nature of the applied substrates.

The most important result of corrosion tests is that the TiC/a:C protective coating on various substrates, while providing a high hardness to the surface, they also resist the electrochemical processes. The TiC/a:C coated sandblasted TiAl6V4 alloy possess the highest polarization resistances over time while the lowest resistances belong to coated polished wafers. It was observed from the ICP-OES results that the TiC/a:C coated sandblasted TiAl6V4 alloy prevents the dissolution of both $\mathrm{Ti}$ and $\mathrm{Al}$ to the simulated body fluid.

Based on the biocompatibility and viability tests of the thin films, it was found that the cells are proliferated on the TiC/a:C thin film, so the films are non-toxic, biocompatible and the viability of the cells is excellent after 3 days. Furthermore, based on the results of the hydrophilicity tests on the coatings it was found that all films exhibited hydrophobic behavior regardless of the composition.

\section{KÖSZÖNETNYILVÁNÍTÁS}

Elsősorban köszönettel tartozom témavezetőmnek Dr. Balázsi Katalin tudományos főmunkatársnak, a Vékonyréteg-fizika Laboratórium vezetőjének a kutatási lehetőség biztosításáért, munkám során nyújtott segítségéért, a szakmai tapasztalatok mind szélesebb körü elsajátítását szolgáló konferencia részvételek támogatásáért és mindazért a sok - sok biztató szóért és tanácsért, mellyel végigvezetett a doktori fokozat megszerzéséig vezető hosszú és néha nagyon fárasztó úton. 
Köszönettel tartozom a Vékonyréteg-fizika Laboratórium valamennyi volt és jelenlegi dolgozójának, akik mindig készségesen segítettek a munkám során felmerülő problémák, feladatok megoldásában.

Külön köszönöm Dr. Fogarassy Zsolt és Dr. Szívós János barátomnak és kollégámnak a segítőkészséget, baráti jó tanácsokat, mikroszkópozásokat és a mérhetetlen türelmet, amit irányomba mutattak.

Hálásan köszönöm Dr. Barna Péternek, Dr. Radnóczi Györgynek és Dr. Bársony Istvánnak a publikációim és doktori disszertációm megírásához adott tanácsaikat és kutatásaim során szakmailag előrevezető, megfontolt tapasztalataik átadását.

Illés Leventének és Dr. Horváth Zsolt Endrének a SEM és XRD mérések elvégzését, a következő projekteknek pedig az anyagai támogatást: EU FP7/2007-2013, „HypOrth”, MTA Fiatal Kutatói Ösztöndíj, GRACE projekt és Új Nemzeti Kiválósági Program (ÚNKP) ösztöndíj.

Köszönet Vilma Buršíkovának és Marta Vandrovcovának a hidrofilitás és biológiai mérések precíz és gyors megvalósításáért.

Köszönetet mondok az MFA intézetének, volt és jelenlegi igazgatójának, Dr. Bársony Istvánnak és Dr. Pécz Bélának, hogy a kutatásaimhoz az infrastruktúrát és a helyet biztosították, Dr. Lábár Jánosnak, volt Laboratóriumi vezetőnek pedig, hogy 2012-ben egyáltalán megkezdhettem munkámat az MFA Vékonyréteg-fizika Laboratóriumában.

Szeretnék köszönetet mondani a publikációim társszerzőinek, akik mérésekkel, tanácsokkal, ötleteikkel előrébb vitték a munkámat és szakértelmükkel hozzájárultak dolgozatom színvonalának emeléséhez. Külön köszönöm Prof. Dr. Kaptay Györgynek, hogy elméleti számolásaival hozzájárult a doktori munkám megvalósításához.

Köszönetet mondok Dr. Kónya Zoltánnak, a Környezettudományi Doktori Iskola vezetőjének, hogy lehetővé tette doktorim megvalósítását.

Hálásan köszönöm Kelemen Erzsikének és Kelemen Zsuzsának, hogy munkájukkal leegyszerüsítették a bürökrácia számomra kiismerhetetlen útjait és Vitkócziné Kelemen Erzsébet barátnőmnek a nyugtató szavakat, baráti csevejeket. Hálával és köszönettel tartozom Dr. Szakolczai Krisztinának, Bolgár Andreának és Sárosi-Kun Krisztinának a szakmai tanácsokért, biztató szavakért, erőt adó ebédekért és Bolgár Andreának a publikációim és MTMT-s ügyeim karbantartásáért.

Családomnak, barátaimnak és nem utolsó sorban páromnak, Horváth Gábornak pedig hálával tartozom végtelen türelmükért, támogatásukért, szeretetükért, irántam való rendíthetetlen bizalmukért. 


\section{FÜGGELÉK}

\subsection{TÉZISEK}

1.a. Elsőként írtam le titán és szén szobahőmérsékleten történő együttes egyenáramú magnetronos porlasztásával létrehozott $\mathrm{TiC} / \mathrm{a}: \mathrm{C}$ vékonyrétegek mikroszerkezetét a titántartalom függvényében, elektronmikroszkópos, röntgendiffrakciós és elemanalitikai vizsgálatok alapján. Igazoltam, hogy a szobahőmérsékleten növesztett TiC/a:C vékonyrétegek mikroszerkezete a fázisösszetétel függvényében hasonló volt a magasabb, $150-350{ }^{\circ} \mathrm{C}$ közötti leválasztási hőmérsékleten készült rétegekéhez.

1.b. Megállapítottam, hogy a titántartalom szisztematikus változtatásával, 17,5 at\% titántartalom alatt amorf fázis jellemezte a rétegeket, 17,5 at\% feletti titántartalmú rétegek esetében fcc kristályfázisú TiC képződött. A TiC kristályok szemcsemérete a titántartalom növekedésével növekvő tendenciát mutatott, kezdetben különálló szemcsék formájában, majd oszlopos szerkezetté átalakulva. A nanokristályokat körülvevő amorf szén mennyisége fokozatosan csökkent, majd 47 at\% feletti titántartalomnál teljesen eltünt.

1.c. A határfelületi energiákat, nukleációs korlátokat és a különböző fázisokra jellemző nano-termodinamikát figyelembe véve magyarázatot adtam a különböző összetételekre jellemző szerkezetek kialakulására. A szerkezetváltozások követték a kétkomponensü rendszer zónadiagram modelljét, a makroszkopikus Ti - C fázisdiagram alapján 47 at\% titántartalom felett várt fázisátalakulásokat viszont nem tapasztaltam, hcp-Ti fázis 60 at\% Ti tartalomnál sem alakult ki és a szén végig amorf állapotban maradt [S4] [S6].

2. Mérési eredményekkel bizonyítottam, hogy a porlasztott TiC/a:C rétegek elemösszetétele, mikroszerkezete, lokális mechanikai és tribológiai tulajdonságai csak a céltárgyak teljesítményétől függtek, a hordozótól és a rétegvastagságtól nem [S1] [S4] [S5].

3. Igazoltam, hogy keménység és a súrlódási tulajdonságok szempontjából az optimális mikroszerkezetü és fázisösszetételü TiC/a:C vékonyréteg a 38 at\% Ti tartalomnál 
porlasztott, $2 \div 3 \mathrm{~nm}$ vastagságú amorf szénnel elválasztott, átlagosan $4 \div 10 \mathrm{~nm}$ vastagságú globuláris fcc TiC nanokristályokat tartalmazó nanokompozit réteg volt. Kísérleti eredményekkel bizonyítottam, hogy ezzel az optimális TiC/a:C nanokompozit bevonat felvitelével a kemény-bevonat nélküli Ti, vagy TiAl6V4 implantátum anyagok mind keménységi -, mind súrlódási együttható értékei sokszorosan javultak [S3] [S6].

4.a. A különböző hordozókra leválasztott TiC/a:C rétegek különböző oldatokban végzett korróziós tesztelésével bizonyítottam, hogy a legmagasabb korróziós ellenállást és a legkevesebb visszamaradt korróziós terméket az optimális $\mathrm{TiC} / \mathrm{a}: \mathrm{C}$ réteggel bevont szemcseszórt felületű TiAl6V4 alapfém biztosította.

4.b. Bizonyítottam, hogy szimulált testnedv folyadékban, 7,4-es pH értéken, a szemcseszórt TiAl6V4 felületü alapfémre felvitt optimális $\mathrm{TiC} / \mathrm{a}: \mathrm{C}$ réteg meggátolta $\mathrm{az}$ Al és Ti ionok kijutását [S2] [S5]. 
9.2. Tézisekhez szorosan kapcsolódó saját publikációk jegyzéke

[S1] Oláh N, Veres M, Sulyok A, Menyhárd M, Gubicza J, Balázsi K: Examination of nanocrystalline TiC/amorphous $\mathrm{C}$ deposited thin films

JOURNAL OF THE EUROPEAN CERAMIC SOCIETY 34:(14) pp. 3421-3425. (2014)

(IF 2,36) doi:10.1016/j.jeurceramsoc.2013.12.006; Folyóiratcikk/Szakcikk/Tudományos

[S2] Nikolett Oláh, Zsolt Fogarassy, Mónika Furkó, Csaba Balázsi, Katalin Balázsi: Sputtered nanocrystalline ceramic TiC / amorphous $\mathrm{C}$ thin films as potential materials for medical applications

CERAMICS INTERNATIONAL 41:(4) pp. 5863-5871. (2015) (IF 2,086$)$ doi:10.1016/j.ceramint.2015.01.017; Folyóiratcikk/Szakcikk/Tudományos

[S3] Oláh Nikolett, Fogarassy Zsolt, Sulyok Attila, Szívós János, Csanádi Tamás, Balázsi Katalin: Ceramic TiC/a:C protective nanocomposite coatings: Structure and composition versus mechanical properties and tribology

CERAMICS INTERNATIONAL 42:(10) pp. 12215-12220. (2016) (IF: 2,758)

doi:10.1016/j.ceramint.2016.04.164; Folyóiratcikk/Szakcikk/Tudományos

[S4] Nikolett Oláh, Zsolt Fogarassy, Attila Sulyok, Miklós Veres, George Kaptay, Katalin Balázsi: TiC crystallite formation and the role of interfacial energies on the composition during the deposition process of TiC/a: $\mathrm{C}$ thin films

SURFACE AND COATINGS TECHNOLOGY 302: pp. 410-419. (2016) (IF 2,139)

doi:10.1016/j.surfcoat.2016.06.047; Folyóiratcikk/Szakcikk/Tudományos

[S5] Nikolett Oláh, Mónika Furkó, Zoltán May, Attila Sulyok, Katalin Balázsi: Mechanical characterization and corrosion behavior of protective TiC/amorphous $\mathrm{C}$ nanocomposite coating as surface thin film

RESOLUTION AND DISCOVERY 2:(1) pp. 43. 10 p. (2017) (IF NÉLKÜLI)

https://doi.org/10.1556/2051.2017.00043; Folyóiratcikk/Szakcikk/Tudományos

[S6] Fogarassy Zsolt, Oláh Nikolett, Cora Ildikó, Horváth Zsolt Endre, Csanádi Tamás, Sulyok Attila, Balázsi Katalin, The structural and mechanical characterization of TiC 
and TiC/Ti thin films grown by DC magnetron sputtering, JOURNAL OF THE EUROPEAN CERAMIC SOCIETY 38:(7) pp. 2886-2892. (2018) (IF 3,411)

https://doi.org/10.1016/j.jeurceramsoc.2018.02.033; Folyóiratcikk/Szakcikk/Tudományos

9.3. Egyéb, a tézisekhez nem szorosan kapcsolódó publikációim jegyzéke

[E1] Carta D, Loche D, Casula MF, Oláh N, Olasz D, Corrias A: Nickel-based nanocrystals dispersed on SBA-16 gels: Synthesis and structural characterization JOURNAL OF NON-CRYSTALLINE SOLIDS 401: pp. 134-138. (2014) (IF 1,579) doi:10.1016/j.jnoncrysol.2014.01.010; Folyóiratcikk/Szakcikk/Tudományos

[E2] Oláh Nikolett, Daniela Carta, Kónya Zoltán, Vízből történő nehézfém eltávolítás szén nanocsövekkel és mezopórusos szilikákkal, ANYAGOK VILÁGA 12:(1) pp. 41-57. (2015) (IF NÉLKÜLI) http://real.mtak.hu/id/eprint/31040; Folyóiratcikk/Szakcikk/Tudományos

[E3] Doina CRACIUN, Gabriel Socol, Daniel V Cristea, Maria Stoicanescu, Nikolett Olah, Katalin Balaszi, Nicolaie Stefan, Mechanical properties of pulsed laser deposited nanocrystalline SiC films, APPLIED SURFACE SCIENCE 336: pp. 391-395. (2015) (IF 2,538) doi:10.1016/j.apsusc.2014.12.186; Folyóiratcikk/Szakcikk/Tudományos

[E4] Nikolett Oláh, Miklós Veres, Attila Sulyok, Zsolt Fogarassy, George Kaptay, Katalin Balázsi, STRUCTURAL CHARACTERIZATION OF TiC-BASED THIN FILMS BY TEM AND HREM, In: Ágnes Kittel, Béla Pécz (ed.) $12^{\text {th }}$ Multinational Congress on Microscopy: MCM 2015. 599 p.

Conference: Eger, Hungary, 23/08/2015 - 28/08/2015 Budapest: Academic Press, 2015. pp. 148-150. (ISBN:978-963-05-9653-4); Könyvrészlet/Absztrakt / Kivonat/Tudományos

\subsection{Az értekezés alapjául szolgáló konferencia részvételek (előadások, poszterek):}

1. Oláh Nikolett, Veres Miklós, Sulyok Attila, Menyhárd Miklós, Gubicza Jenő, Balázsi Katalin, Examination of nanocrystallite TiC/amorphous $\mathbf{C}$ deposited thin 
films, Országos Anyagtudományi Konferencia (OATK), Balatonkenese, 2013. Október 13 - 15, poszter

2. Oláh Nikolett, Veres Miklós, Sulyok Attila, Menyhárd Miklós, Gubicza Jenő, Balázsi Katalin, Examination of nanocrystallite TiC/amorphous $\mathbf{C}$ deposited thin films, International Conference Fractography of Advanced Ceramics (FAC), Szomolány, Szlovákia, 2013. Szeptember 29 - Október 2, poszter

3. Oláh Nikolett, Illés Levente, Sulyok Attila, Menyhárd Miklós, Balázsi Csaba, Furkó Mónika, Balázsi Katalin, Sputtered nanocrystalline $\mathbf{T i C}$ / amorphous $\mathrm{C}$ thin films for medical applications, International workshop on Coatings \& Surfaces for Biomedical Engineering (IWCSB) 2014, IIT Madras, Chennai, India, 2014. Február 16 - 19, szóbeli előadás

4. Oláh Nikolett, Fogarassy Zsolt, Sulyok Attila, Tapasztó Orsolya, Balázsi Csaba, Furkó Mónika, Balázsi Katalin, Sputtered nanocrystalline TiC/ amorphous $\mathbf{C}$ thin films as potential materials for medical applications, Magyar Mikroszkópos Társaság éves konferenciája, 2014. Május 29 - 31, Siófok, Balaton, szóbeli előadás. Különdíjas elöadás, a 2015 augusztusában, Egerben rendezendö Multinational Congress on Microscopy részvételi dijának térítése.

5. Oláh Nikolett, Veres Miklós, Sulyok Attila, Furkó Mónika, Fogarassy Zsolt, Balázsi Csaba, Balázsi Katalin, Biocompatible TiC / amorphous $\mathbf{C}$ thin films prepared by DC magnetron sputtering, $15^{\text {th }}$ Joint Vacuum Conference, 2014. Június $15-20$, Bécs, Ausztria, poszter

6. Oláh Nikolett, Fogarassy Zsolt, Sulyok Attila, Menyhárd Miklós, Kaptay Gyögy, Balázsi Katalin, Microscopic study of TiC / amorphous C thin films, $18^{\text {th }}$ International Microscopy Congress (IMC) 2014 Prága, Csehország, 2014. Szeptember 7 - 12, poszter. Ösztöndíj, részvételi díjamat az Európai Mikroszkópos Társaság finanszírozta.

7. Oláh Nikolett, Kaptay György, Fogarassy Zsolt, Sulyok Attila, Tapasztó Orsolya, Balázsi Katalin, Comparison of experimental results with semi-empirical equation of deposited nc-TiC / C thin films, $6^{\text {th }}$ Szeged International Workshop on Advances in Nanoscience (Siwan6) Szeged, Magyarország, 2014. Október 15 - 18, poszter

8. Oláh Nikolett, Veres Miklós, Sulyok Attila, Furkó Mónika, Fogarassy Zsolt, Balázsi Csaba, Balázsi Katalin, Biocompatible TiC / amorphous C thin films prepared by 
DC magnetron sputtering, $16^{\text {th }}$ International Conference on Thin Films (ICTF16) Dubrovnik, Horvátország, 2014. Október 13 - 16, poszter

9. Oláh Nikolett, Kaptay György, Fogarassy Zsolt, Sulyok Attila, Csanádi Tamás, Balázsi Katalin, Characterization of deposited nc-TiC / $\mathrm{C}$ thin films as protective coatings, $5^{\text {th }}$ International Advances in Applied Physics and Materials Science Congress \& Exhibition (APMAS 2015) 2015. Április 16 - 19, Sentido Lykia Resort, Oludeniz/ Törökország, poszter

10. Oláh Nikolett, Biocompatible ceramic TiC / amorphous $\mathrm{C}$ thin films prepared by DC magnetron sputtering, $14^{\text {th }}$ International Conference European Ceramic Society (ECerS 14) 2015. Június 21 - 25, Toledo, Spanyolország, szóbeli előadás. Kiválasztottak a 2015. Június 21-25. között Toledoban (Spanyolország) tartandó ECerS 14 konferencián megrendezendö „ECerS student speech contest” verseny résztvevōjének.

11. Oláh Nikolett, Structural characterization of TiC based thin films by TEM and HRTEM, Multinational Congress on Microscopy, MCM 2015, 2015. Augusztus 23 28, Eger, Magyarország, szóbeli előadás

12. Oláh Nikolett, Fogarassy Zsolt, Sulyok Attila, Veres Miklós, Kaptay György, Csanádi Tamás, Balázsi Katalin, Védőbevonat alkalmazásra fejlesztett nanokompozit TiC / C vékonyrétegek jellemzése, X. Országos Anyagtudományi Konferencia, 2015. október 11 - 13. Balatonalmádi, 5 perces előadás poszterrel

13. Oláh N., Fogarassy Zs., Szívós J., Sulyok A., Furkó M., Csanádi T., Balázsi K., Structural investigation, mechanical properties and corrosion behavior of magnetron-sputtered nanocomposite TiC/a:C thin film coatings, Magyar Mikroszkópos Társaság éves konferenciája, 2016. Május 19 - 21, Siófok, Balaton, szóbeli előadás

14. Oláh N., Fogarassy Zs., Szívós J., Sulyok A., Furkó M., Csanádi T., Balázsi K., Structural investigation, mechanical properties and corrosion behavior of magnetron-sputtered nanocomposite TiC/a:C coatings, $16^{\text {th }} \mathrm{Joint}$ Vacuum Conference 2016. Június 6 - 10, Portorož, Szlovénia, szóbeli előadás

15. HypOrth Meeting Bilbaoban, Spanyolország, 2016. Június 29 - Július 2, 2 poszter

16. Oláh N., Fogarassy Zs., Szívós J., Sulyok A., Balázsi C., Balázsi K., Structural investigation, corrosion properties and adhesion behavior of magnetron sputtered nanocomposite $\mathrm{TiC} / \mathrm{a}: \mathrm{C}$ thin film coatings, $16^{\text {th }}$ European Microscopy 
Congress, 2016. Augusztus 28 - Szeptember 2, Lyon, Franciaország, poszter. Ösztöndíj, részvételi díjamat az Európai Mikroszkópos Társaság finanszírozta.

\section{IRODALOMJEGYZÉK}

[1] Hernádi Klára and Kónya Zoltán, "Nanokompozitok," Szegedi Tudományegyetem, Szeged, TÁMOP-4.1.2.A/1-11/1 MSc Tananyagfejlesztés 2012.

[2] Dr. Konczos Géza, "Korszerű anyagok és technológiák," MTA Szilárdtestfizikai és Optikai Kutató Intézet, Budapest, Egyetemi jegyzet 1995.

[3] P.F. Santos, M. Niinomi, K. Cho, M. Nakai, H. Liu, N. Ohtsu, M. Hirano, M. Ikeda, and T. Narushima, "Microstructures, mechanical properties and cytotoxicity of low cost beta Ti-Mn alloys for biomedical applications," Acta Biomater., vol. 26, pp. 366-376, 2015.

[4] I. Milošev, M. Metikoš-Huković, and H.-H. Strehblow, "Passive film on orthopaedic TiAlV alloy formed in physiological solution investigated by X-ray photoelectron spectroscopy," Biomaterials, vol. 21, pp. 2103-2113, 2000.

[5] E. Matykina, R. Arrabal, R.Z. Valiev, J.M. Molina-Aldareguia, P. Belov, and I. Sabirov, "Electrochemical Anisotropy of Nanostructured Titanium for Biomedical Implants," Electrochim. Acta, vol. 176, pp. 1221-1232, 2015.

[6] N.T.C. Oliveira and A.C. Guastaldi, "Electrochemical stability and corrosion resistance of Ti-Mo alloys for biomedical applications," Acta Biomater., vol. 5, pp. 399-405, 2009.

[7] Csanády Andrásné, Kálmán Erika, and Konczos Gábor, Bevezetés a nanoszerkezetű anyagok világába, MTA Kémiai Kutatóközpont ed. Budapest: ELTE Eötvös kiadó, 2009.

[8] Y.T. Pei, D. Galvan, and J.Th.M. De Hosson, "Nanostructure and properties of TiC/a-C:H composite coatings," Acta. Mater., vol. 53, pp. 4505-4521, 2005.

[9] Y.T. Pei, D. Galvan, J.Th.M. De Hosson, and C. Strondl, "Advanced TiC/a-C:H nanocomposite coatings deposited by magnetron sputtering," J. Eur. Ceram. Soc., vol. 26, pp. 565-570, 2006.

[10] K.P. Shaha, Y.T. Pei, D. Martínez-Martínez, J.C. Sanchez-Lopez, and J.Th.M. De Hosson, "Effect of process parameters on mechanical and tribological performance of pulsed-DC sputtered TiC/a-C:H nanocomposite films," Surf. Coat. Technol., vol. 205, pp. 2633-2642, 2010.

[11] N. Oláh, C. Daniela, and Z. Kónya, "Vízből történő nehézfém eltávolítás szén nanocsövekkel és mezopórusos szilikákkal," ANYAGOK VILÁGA, vol. 12, no. 1, pp. 41-57, 2015.

[12] B.E. Jacobson, C.V. Deshpandey, H.J. Doerr, A.A. Karim, and R.F. Bunshah, "Microstructure and hardness of $\mathrm{Ti}(\mathrm{C}, \mathrm{N})$ coatings on steel prepared by the activated reactive evaporation 
technique," Thin Solid Films, vol. 118, p. 285, 1984.

[13] A.A. Voevodin, S.V. Prasad, and J.S. Zabinski, "Nanocrystalline carbide/amorphous carbon composites," J. Appl. Phys., vol. 82, pp. 855-858, 1997.

[14] J. Patscheider, T. Zehnder, and M. Diserens, "Structure-performance relations in nanocomposite coatings," Surf. Coat. Technol., vol. 146-147, pp. 201-208, 2001.

[15] H.M. Gabriel and K.H. Kloos, "Morphology and structure of ion-plated TiN, TiC and Ti (C, N) coatings," Thin Solid Films, vol. 118, p. 243, 1984.

[16] A. Matthews and S.S. Eskildsen, "Engineering applications for diamond-like carbon," Diamond Relat. Mater., vol. 3, p. 902, 1994.

[17] D. Roth, B. Rau, S. Roth, J. Mai, and K.H. Dittrich, "Large area and three-dimensional deposition of diamond-like carbon films for industrial applications," Surf. Coat. Technol., vol. 74-75, p. 637, 1995.

[18] D.V. Shtansky, N.A. Gloushankova, I.A. Bashkova, M.I. Petrzhik, A.N. Sheveiko, F.V. Kiryukhantsev-Korneev, I.V. Reshetov, A.S. Grigoryan, and E.A. Levashov, "Multifunctional biocompatible nanostructured coatings for load-bearing implants," Surf. Coat. Technol., vol. 201, no. 7, pp. 4111-4118, 2006.

[19] M.A.-H. Gepreel and M. Niinomi, "Biocompatibility of Ti-alloys for long-term implantation," J. Mech. Behav. Biomed. Mater., vol. 20, pp. 407-415, 2013.

[20] L. Thair, U.K. Mudali, S. Rajagopalan, R. Asokamani, and B. Raj, "Surface characterization of passive film formed on nitrogen ion implanted Ti-6AI-4V and Ti-6AI-7Nb alloys using SIMS," Corros. Sci., vol. 45, pp. 1951-1967, 2003.

[21] Q. Wang, F. Zhou, Z. Zhou, L. K.-Y. Li, and J. Yan, "Electrochemical performance of TiCN coatings with low carbon concentration in simulated body fluid," Surf. Coat. Technol., vol. 253, pp. 199-204, 2014.

[22] S. Sedira, S. Achour, A. Avci, and V. Eskizeybek, "Physical deposition of carbon doped titanium nitride film by DC magnetron sputtering for metallic implant coating use," Appl. Surf. Sci. , vol. 295, pp. 81-85, 2014.

[23] R.W.-W. Hsu, C.-C.Yang, C.-A.Huang, and Y.-S. Chen, "Investigation on the corrosion behavior of Ti-6Al-4V implant alloy by electrochemical techniques," Mater. Chem. Phys., vol. 86, pp. 269-278, 2004.

[24] S. Kadlec, J. Musil, V. Valvoda, W.-D. Münz, H. Petersein, and J. Schroeder, "TiN films grown by reactive magnetron sputtering with enhanced ionization at low discharge pressures," Vacuum, vol. 41, pp. 2233-2238, 1990. 
[25] P. Souček, T. Schmidtová, L. Zábranský, V. Buršíková, P. Vašina, O. Caha, M. Jílek, A. El Mel, P.Y. Tessier, J. Schäfer, J. Buršík, V. Peřina, and R. Mikšová, "Evaluation of composition, mechanical properties and structure of $\mathrm{nc}-\mathrm{TiC} / \mathrm{a}-\mathrm{C}: \mathrm{H}$ coatings prepared by balanced magnetron sputtering," Surf. Coat. Technol., vol. 211, pp. 111-116, 2012.

[26] A.G. Kahrizsangi and S.F.K. Bozorg, "Microstructure and mechanical properties of steel/TiC nano-composite surface layer produced by friction stir processing," Surf. Coat. Technol., vol. 209, pp. 15-22, 2012.

[27] D. Martínez-Martínez, C. López-Cartes, A. Fernández, and J.C. Sánchez-López, "Comparative performance of nanocomposite coatings of TiC or TiN dispersed in a-C matrixes," Surf. Coat. Technol., vol. 203, pp. 756-760, 2008.

[28] Y. Wang, J. Wang, G. Zhang, L. Wang, and P. Yan, "Microstructure and tribology of TiC(Ag)/aC:H nanocomposite coatings deposited by unbalanced magnetron sputtering," Surf. Coat. Technol., vol. 206, pp. 3299-3308, 2012.

[29] W. Li, F. Li-hong, and G. Jian-hong, "First-principles study of TiC(110) surface," Trans. Nonferrous Met. Soc. China, vol. 22, pp. 170-174, 2012.

[30] L.M. Liu, S.Q. Wang, and H.Q. Ye, "First-principle study of the polar TiC/Ti interface," J. Mater. Sci. Technol., vol. 19, pp. 540-544, 2003.

[31] N. Kumar, G. Natarajan, R. Dumpala, R. Pandian, A. Bahuguna, S.K. Srivastava, T.R. Ravindran, S. Rajagopalan, S. Dash, A.K. Tyagi, and M.S.R. Rao, "Microstructure and phase composition dependent tribological properties of TiC/a-C nanocomposite thin films," Surf. Coat. Technol., vol. 258, pp. 557-565, 2014.

[32] P. Souček, T. Schmidtová, L. Zábranský, V. Buršíková, P. Vašina, O. Caha, J. Buršík, V. Peřina, R. Mikšová, Y.T. Pei, and J.Th.M. De Hosson, "On the control of deposition process for enhanced mechanical properties of nc-TiC/a-C:H coatings with DC magnetron sputtering at low or high ion flux," Surf. Coat. Technol., vol. 255, pp. 8-14, 2014.

[33] R. Ahuja, O. Eriksson, J.M. Wills, and B. Johansson, "Structural, elastic, and high-pressure properties of cubic TiC, TiN, and TiO," Phys. Rev. B, vol. 53, p. 3072, 1996.

[34] K. Balázsi, M. Vandrovcová, L. Bačáková, and Cs. Balázsi, "Structural and biocompatible characterization of TiC/a:C nanocomposite thin films," Mat. Sci. Eng. C, vol. 33, pp. 1671-1675, 2013.

[35] J. Musil, "Hard and superhard nanocomposite coatings," Surf. Coat. Technol., vol. 125, p. 322, 2000.

[36] Y.T. Pei, D. Galvan, J.Th.M. De Hosson, and A. Cavaleiro, "Nanostructured TiC/a-C coatings for low friction and wear resistant applications," Surf. Coat. Technol., vol. 198, pp. 44-50, 2005. 
[37] I. Petrov, P. B. Barna, L. Hultman, and J. E. Greene, "Microstructural evolution during film growth," J.Vac. Sci. Technol. A: Vacuum, Surfaces, and Films, vol. 21, no. 5, pp. 117-127, 2003.

[38] D. Martínez-Martínez, C. López-Cartes, A. Fernández, and J.C. Sánchez-López, "Influence of the microstrucutre on the mechanical and tribological behavior of TiC/a-C nanocomposite coatings," Thin Solid Films, vol. 517, pp. 1662-1671, 2009.

[39] J. Chen, W. Li, and W. Jiang, "Characterization of sintered TiC-SiC composites," Ceram. Int., vol. 35, pp. 3125-3129, 2009.

[40] J. Cabrero, F. Audubert, and R. Pailler, "Fabrication and characterization of sintered TiC-SiC composites," J. Eur. Ceram. Soc., vol. 31, pp. 313-320, 2011.

[41] M. Zhou, P.D.D. Rodrigo, X. Wang, J. Hu, S. Dong, and Y.-B. Cheng, "A novel approach for preparation of dense TiC-SiC nanocomposites by sol-gel infiltration and spark plasma sintering," J. Eur. Ceram. Soc., vol. 34, pp. 1949-1954, 2014.

[42] R. Kumar, A.K. Chaubey, S. Bathula, B.B. Jha, and A. Dhar, "Synthesis and characterization of Al2O3-TiC nano-composite by spark plasma sintering," Int. J. Refract. Met. Hard Mater., vol. 54, pp. 304-308, 2016.

[43] A. Contreras, C. Angeles-Chávez, O. Flores, and R. Perez, "Structural, morphological and interfacial characterization of Al-Mg/TiC composites," Mater. Charact., vol. 58, pp. 685-693, 2007.

[44] O. Verezub, Z. Kálazi, G. Buza, N.V. Verezub, and G. Kaptay, "In-situ synthesis of a carbide reinforced steel matrix surface nanocomposite by laser melt injection technology and subsequent heat treatment," Surf. Coat. Technol. , vol. 203, pp. 3049-3057, 2009.

[45] K.H.T. Raman, M.S.R.N. Kiran, U. Ramamurty, and G. Mohan Rao, "Structure and mechanical properties of Ti-C films deposited using combination of pulsed DC and normal DC magnetron co-sputtering," Appl. Surf. Sci., vol. 258, pp. 8629-8635, 2012.

[46] A. Ignaszak, C. Song, W. Zhu, J. Zhang, A. Bauer, R. Baker, V. Neburchilov, S. Ye, and S. Campbell, "Titanium carbide and its core-shelled derivative TiC@TiO2 as catalyst supports for proton exchange membrane fuel cells," Electrochim. Acta, vol. 69, pp. 397-405, 2012.

[47] Y.C. Kimmel, L. Yang, T.G. Kelly, S.A. Rykov, and J.G. Chen, "Theoretical prediction and experimental verification of low loading of platinum on titanium carbide as low-cost and stable electrocatalysts," J. Catal., vol. 312, pp. 216-220, 2014.

[48] K. Balázsi, M. Vandrovcová, L. Bačáková, C. Balázsi, I. Bertóti, F. Davin, and G. Radnóczi, "Mechanical behavior of bioactive TiC nanocomposite thin films," Mater. Sci. Forum, vol. 729, pp. 296-301, 2013.

[49] P. Yuan, D. Gu, and D. Dai, "Particulate migration behavior and its mechanism during selective 
laser melting of TiC reinforced Al matrix nanocomposites," Mater. Des., vol. 82, pp. 46-55, 2015.

[50] D. Gu, H. Wang, F. Chang, D. Dai, P. Yuan, Y.-C. Hagedorn, and W. Meiners, "Selective Laser Melting Additive Manufacturing of TiC/AlSi10Mg Bulk-form Nanocomposites with Tailored Microstructures and Properties," Phys. Procedia, vol. 56, pp. 108-116, 2014.

[51] M. Stüber, H. Leiste, S. Ulrich, H. Holleck, and D. Schild, "Microstructure and properties of low friction TiC-C nanocomposite coatings deposited by magnetron sputtering," Surf. Coat. Technol., vol. 150, pp. 218-226, 2002.

[52] A. Mani, P. Aubert, F. Mercier, H. Khodja, C. Berthier, and P. Houdy, "Effects of residual stress on the mechanical and structural properties of TiC thin films grown by RF sputtering," Surf. Coat. Technol., vol. 194, pp. 190-195, 2005.

[53] A. Zouina, A. Djafer, N. Saoula, N. Madaoui, and A. Zerizer, "Deposition and characterization of titanium carbide thin films by magnetron sputtering using Ti and TiC targets," Appl. Surf. Sci., vol. 312, pp. 57-62, 2014.

[54] A.A. El Mel, B. Angleraud, E. Gautron, A. Granier, and P.Y. Tessier, "Microstructure and composition of TiC/a-C:H nanocomposite thin films deposited by a hybrid IPVD/PECVD process," Surf. Coat. Technol., vol. 204, pp. 1880-1883, 2010.

[55] Y. Wang, X. Zhang, X. Wu, H. Zhang, and X. Zhang, "Compositional, structural and mechanical characteristics of nc-TiC/a-C:H nanocomposite films," Appl. Surf. Sci., vol. 255, pp. 1801-1805, 2008.

[56] A.A. El Mel, B. Angleraud, E. Gautron, A. Garnier, and P.Y. Tessier, "XPS study of the surface composition modification of $\mathrm{nc}-\mathrm{TiC} / \mathrm{C}$ nanocomposite films under in situ argon ion bombardment," Thin Solid Films, vol. 519, pp. 3982-3985, 2011.

[57] J.L. He H.L. Wang and M.H. Hon, "Sliding wear resistance of TiCN coatings on tool steel made by plasma-enhanced chemical vapour deposition," Wear, vol. 169, p. 195, 1993.

[58] D. Galvan, Y.T. Pei, and J.Th.M. De Hosson, "Influence of deposition parameters on the structure and mechanical properties of nanocomposite coatings," Surf. Coat. Technol., vol. 201, no. 3-4, pp. 590-598, 2006.

[59] J.M. Lackner, W. Waldhauser, and R. Ebner, "Large-area high-rate pulsed laser deposition of smooth TiCxN1-x coatings at room temperature-mechanical and tribological properties," Surf. Coat. Technol., vol. 188-189, pp. 519-524, 2004.

[60] K. Sedláčková, T. Ujvári, R. Grasin, P. Lobotka, I. Bertóti, and G. Radnóczi, "C-Ti nanocomposite thin films: Structure, mechanical and electrical properties," Vacuum, vol. 82, pp. 214-216, 2008. 
[61] W.J. Meng, R.C. Tittsworth, and L.E. Rehn, "Mechanical properties and microstructure of TiC/amorphous hydrocarbon nanocomposite coatings," Thin Solid Films, vol. 377/378, pp. 222232, 2000.

[62] Ž. Mitić, A. Stolić, S Stojanović, S. Najman, N. Ignjatović, G. Nikolić, and M. Trajanović, "Instrumental methods and techniques for structural and physicochemical characterization of biomaterials and bone tissue: A review," Mat. Sci.Eng. C, vol. 79, pp. 930-949, 2017.

[63] V. Perrotti, A. Piattelli, A. Quaranta, G. Gómez-Moreno, and G. lezzi, "Biocompatibility of dental biomaterials," in Biomaterials.: Woodhead Publishing Series , 2017, ch. 1, pp. 1-7.

[64] Joób - Fancsaly Árpád, "Fogászati implantátumok felületi morfológiájának vizsgálata," Semmelweis Egyetem, Szájsebészeti és Fogászati Klinika, Budapest, Doktori (Ph.D.) értekezés 2003.

[65] M. Lakatos-Varsányi, M. Furkó, and T. Pozman, "Electrochemical impedance spectroscopy study on silver coated metallica implants," Electrochim. Acta, vol. 56, pp. 7787-7795, 2011.

[66] R.W.-W. Hsu, C.-C.Yang, C.-A.Huang, and Y.-S. Chen, "Electrochemical corrosion studies on CoCr-Mo implant alloy in biological solutions," Mater. Chem. Phys., vol. 93, pp. 531-538, 2005.

[67] M.T. Choy, C.Y. Tang, L. Chen, C.T. Wong, and C.P. Tsui, "In vitro and in vivo performance of bioactive Ti6Al4V/TiC/HA implants fabricated by a rapid microwave sintering technique," Mat. Sci. Eng. C, vol. 42, pp. 746-756, 2014.

[68] I. Cvijović-Alagić, Z. Cvijović, S. Mitrović, V. Panić, and M. Rakin, "Wear and corrosion behaviour of Ti-13Nb-13Zr and Ti-6Al-4V alloys in simulated physiological solution," Corros. Sci., vol. 53, pp. 796-808, 2011.

[69] A. Dalmau, V.G. Pina, F. Devesa, V. Amigó, and A.I. Muñoz, "Influence of fabrication process on electrochemical and surface properties of Ti-6Al-4V alloy for medical applications," Electrochim. Acta, vol. 95, pp. 102-111, 2013.

[70] J.E.G. González and J.C. Mirza-Rosca, "Study of the corrosion behavior of titanium and some of its alloys for biomedical and dental implnat applications," J. Electroanal. Chem., vol. 471, pp. 109-115, 1999.

[71] A.M. Soufiani, F. Karimzadeh, and M.H. Enayati, "Formation mechanism and characterization of nanostructured Ti6Al4V alloy prepared by mechanical alloying," Mater. Des., vol. 37, pp. 152-160, 2012.

[72] L. Chenghao, J. Li'nan, Y. Chuanjun, and H. Naibao, "Crevice Corrosion Behavior of CP Ti, Ti-6Al4V Alloy and Ti-Ni Shape Memory Alloy in Artificial Body Fluids," Rare. Metal. Mat. Eng., vol. 44, pp. 0781-0785, 2015.

[73] N.T.C. Oliveira, G. Aleixo, R. Caram, and A.C. Guastaldi, "Development of Ti-Mo alloys for 
biomedical applications: Microstructure and electrochemical characterization," Mat. Sci. Eng. A, vol. 452-453, pp. 727-731, 2007.

[74] L. Le Guéhennec, A. Soueidan, P. Layrolle, and Y. Amouriq, "Surface treatments of titanium dental implants for rapid osseointegration," Dent. Mater. , vol. 23, pp. 844-854, 2007.

[75] P.I. Brånemark, B.O.Hansson, R. Adell, U. Breine, J. Lindström, O. Hallén, and A. Ohman, "Osseointegrated implants in the treatment of the edentulous jaw. Experience from a 10-year period.," Scand. J. Plast. Reconstr. Surg. Suppl., vol. 16, pp. 1-132, 1977.

[76] Z. Doni, A.C. Alves, F. Toptan, J.R. Gomes, A. Ramalho, M. Buciumeanu, L. Palaghian, and F.S. Silva, "Dry sliding and tribocorrosion behaviour of hot pressed CoCrMo biomedical alloy as compared with the cast CoCrMo and Ti6Al4V alloys," Mater. Des., vol. 52, pp. 47-57, 2013.

[77] W. Simka, "Preliminary investigations on the anodic oxidation of Ti-13Nb-13Zr alloy in a solution containing calcium and phosphorus," Electrochim. Acta, vol. 56, pp. 9831-9837, 2011.

[78] I. Gurappa, "Characterization of titanium alloy Ti-6Al-4V for chemical, marine and industrial applications," Mater. Charact., vol. 51, pp. 131-139, 2003.

[79] I. Gurappa, "Characterization of different materials for corrosion resistance under simulated body fluid conditions," Mater. Charact., vol. 49, pp. 73-79, 2002.

[80] H. Oudadesse, J.L. Irigaray, and E. Chassot, "Detection of metallic elements migration around a prosthesis by neutron activation analysis and by the PIXE method," J. Trace Microprobe Tech., vol. 18, pp. 505-510, 2000.

[81] S. Wu, X. Liu, K.W.K. Yeung, H. Guo, P. Li, T. Hu, C.Y. Chung, and P.K. Chu, "Surface nanoarchitectures and their effects on the mechanical properties and corrosion behavior of Tibased orthopedic implants," Surf. Coat. Technol., vol. 233, pp. 13-26, 2013.

[82] Y. Okazaki, "Effect of friction on anodic polarization properties of metallic biomaterials," Biomaterials, vol. 23, pp. 2071-2077, 2002.

[83] R.M. Souto, M.M. Laz, and R.L. Reis, "Degradation characteristics of hydroxyapatite coatings on orthopaedic TiAlV in simulated physiological media investigated by electrochemical impedance spectroscopy," Biomaterials, vol. 24, pp. 4213-4221, 2003.

[84] A. Martín-Cameán, Á. Jos, P. Mellado-García, A. Iglesias-Linares, E. Solano, and A.M. Cameán, "In vitro and in vivo evidence of the cytotoxic and genotoxic effects of metal ions released by orthodontic appliances: A review," Environ. Toxicol. Phar., vol. 40, pp. 86-113, 2015.

[85] R.W.-W. Hsu, C.-C.Yang, C.-A.Huang, and Y.-S. Chen, "Electrochemical corrosion studies on CoCr-Mo implant alloy in biological solutions," Mater. Chem. Phys., vol. 93, pp. 531-538, 2005.

[86] Y. Okazaki and E. Gotoh, "Metal release from stainless steel, Co-Cr-Mo-Ni-Fe and $\mathrm{Ni}$-Ti alloys in 
vascular implants," Corros. Sci., vol. 50, pp. 3429-3438, 2008.

[87] H. Liu, D. Zhang, F. Shen, G. Zhang, and S. Song, "Corrosion and ion release behavior of Cu/Ti film prepared via physical vapor deposition in vitro as potential biomaterials for cardiovascular devices," Appl. Surf. Sci., vol. 258, pp. 7286-7291, 2012.

[88] P.F. Santos, M. Niinomi, H. Liu, K. Cho, M. Nakai, Y. Itoh, T. Narushima, and M. Ikeda, "Fabrication of low-cost beta-type Ti-Mn alloys for biomedical applications by metal injection molding process and their mechanical properties ," J. Mech. Behav. Biomed. Mater., vol. 59, pp. 497-507, 2016.

[89] D.R.N. Correa, P.A.B. Kuroda, C.R. Grandini, L.A. Rocha, F.G.M. Oliveira, A.C. Alves, and F. Toptan, "Tribocorrosion behavior of $\beta$-type Ti-15Zr-based alloys," Mater. Lett., vol. 179, pp. 118-121, 2016.

[90] X. Wang, L. Zhang, Z. Guo, Y. Jiang, X. Tao, and L. Liu, "Study of low-modulus biomedical $\beta$ Ti$\mathrm{Nb}-\mathrm{Zr}$ alloys based on single-crystal elastic constants modeling," J. Mech. Behav. Biomed. Mater. , vol. 62, pp. 310-318, 2016.

[91] L. Zhang, K. Wang, L. Xu, S. Xiao, and Y. Chen, "Effect of Nb addition on microstructure, mechanical properties and castability of $\beta$-type Ti-Mo alloys ," Trans. Nonferrous Met. Soc. China, vol. 25, pp. 2214-2220, 2015.

[92] M.A. Khan, R.L. Williams, and D.F. Williams, "The corrosion behaviour of Ti-6Al-4V, Ti-6Al-7Nb and Ti-13Nb-13Zr in protein solutions ," Biomaterials, vol. 20, pp. 631-637, 1999.

[93] A.J. Perry, "Ion implantation of titanium alloys for biomaterial and other applications, ," Surf. Eng., vol. 3, pp. 154-160, 1987.

[94] A. Piattelli, A. Scarano, M. Piattelli, and L. Calabrese, "Direct bone formation on sand-blasted titanium implants: an experimental study," Biomaterials, vol. 17, pp. 1015-1018, 1996.

[95] W.-C. Chen, Y.-S. Chen, C.-L.Ko, Y. Lin, T.-H. Kuo, and H.-N. Kuo, "Interaction of progenitor bone cells with different surface modifications of titanium implant," Mater. Sci. Eng. C, vol. 37, pp. 305-313, 2014.

[96] G.K. Meenashisundaram and M. Gupta, "Synthesis and characterization of high performance low volume fraction $\mathrm{TiC}$ reinforced $\mathrm{Mg}$ nanocomposites targeting biocompatible/structural applications," Mater. Sci. Eng. A, vol. 627, pp. 306-315, 2015.

[97] H.B. Wen, J.R. de Wijn, F.Z. Cui, and K. de Groot, "Preparation of bioactive Ti6Al4V surfaces by a simple method," Biomaterials, vol. 19, pp. 215-221, 1988.

[98] T. Hanawa, "In vivo metallic biomaterials and surface modification," Mater. Sci. Eng. A, vol. 267, pp. 260-266, 1999. 
[99] M. Browne and P.J. Gregson, "Effect of mechanical surface pretreatment on metal ion release," Biomaterials, vol. 21, pp. 385-392, 2000.

[100] L. Jinlong, L. Tongxiang, W. Chen, and D. Limin, "Surface corrosion enhancement of passive films on NiTi shape memory alloy in different solutions," Mater. Sci. Eng. C, vol. 63, pp. 192197, 2016.

[101] D.P. Aun, M. Houmard, M. Mermoux, L. Latu-Romain, J.-C. Joud, G. Berthomé, and V.T.L. Buono, "Development of a flexible nanocomposite TiO2 film as a protective coating for bioapplications of superelastic NiTi alloys," Appl. Surf. Sci., vol. 375, pp. 42-49, 2016.

[102] D.G. Li, J.D. Wang, D.R. Chen, and P. Liang, "Influence of passive potential on the electronic property of the passive film formed on $\mathrm{Ti}$ in $0.1 \mathrm{M} \mathrm{HCl}$ solution during ultrasonic cavitation," Ultrason. Sonochem., vol. 29, pp. 48-54, 2016.

[103] A. Shanaghi, P.K. Chu, A.R. SabourRouhaghdam, R. Xu, and T. Hu, "Structure and corrosion resistance of Ti/TiC coatings fabricated by plasma immersion ion implantation and deposition on nickel-titanium," Surf. Coat. Technol., vol. 229, pp. 151-155, 2013.

[104] K. Balázsi, I.E. Lukács, S. Gurbán, M. Menyhárd, L. Bacáková, M. Vandrovcová, and C. Balázsi, "Structural, mechanical and biological comparison of TiC and TiCN nanocomposites films," J. Eur. Ceram. Soc., vol. 33, pp. 2217-2221, 2013.

[105] Q. Wu, W. Li, and N. Zhong, "Corrosion behavior of TiC particle-reinforced 304 stainless steel ," Corros. Sci., vol. 53, pp. 4258-4264, 2011.

[106] H.P. Dang, Q.H. Luc, V.H. Le, and T. Le, "The influence of deposition temperature and annealing temperature on Ga-doped $\mathrm{SnO} 2$ films prepared by direct current magnetron sputtering," J. Alloy. Compd., vol. 687, pp. 1012-1020, 2016.

[107] D. Bociaga, M. Kaminska, A. Sobczyk-Guzenda, K. Jastrzebski, L. Swiatek, and A. Olejnik, "Surface properties and biological behaviour of Si-DLC coatings fabricated by a multi-target DC-RF magnetron sputtering method for medical applications," Diam. Relat. Mater., vol. 67, pp. 41-50, 2016.

[108] C. Wang, Y. Yang, Y.-W. Chung, Y. Zhang, S. Ouyang, Z. Xiao, K. Song, and P. Li, "Microstructure, hardness and toughness of boron carbide thin films deposited by pulse dc magnetron sputtering," Ceram. Int., vol. 42, pp. 6342-6346, 2016.

[109] J. Li, H. Zhang, A. Fan, and B. Tang, "Tribological properties characterization of Ti/Cu/N Thin films prepared by DC magnetron sputtering on titanium alloy," Surf. Coat. Technol., vol. 294, pp. 30-35, 2016.

[110] J. Musil and J Vlček, "Magnetron sputtering of hard nanocomposite coatings and their properties," Surf. Coat. Technol., vol. 142, pp. 557-566, 2001. 
[111] E. Bauer, "Phänomenologische Theorie der Kristallabscheidung an Oberflächen. I," Zeitschrift für Kristallographie, vol. 110, no. 1-6, pp. 372-394, 1958.

[112] D.W. Pashley, M.J. Stowell, M.H. Jacobs, and T.J. Law, "The growth and structure of gold and silver deposits formed by evaporation inside an electron microscope," Philos. Mag., vol. 10, no. 103, pp. 127-158, 1964.

[113] P.B. Barna and M. Adamik, "Fundamental structure forming phenomena of polycrystalline films and the structure zone models," Thin Solid Films, vol. 317, no. 1-2, pp. 27-33, 1998.

[114] A. Barna, B. Pécz, and M. Menyhard, "Amorphisation and surface morphology development at low-energy ion milling," Ultramicroscopy, vol. 70, no. 3, pp. 161-171, 1998.

[115] Á. Barna, G. Radnóczi, and B. Pécz, "Preparation techniques for transmission electron microscopy," in Handbook of Microscopy, S. Amelinckx, D. van Dyck, J. van Landuyt, and G. van Tendelo, Eds. Weinheim, Deutschland: VCH Verlag, 1997, vol. 3, ch. II/3, pp. 751-801.

[116] B. Vincent Crist, Handbook of Monochromatic XPS Spectra, The Elements of Native Oxides, 2000th ed., B. Vincent Crist, Ed. Weinheim, Deutschland: Wiley-VCH, 2000.

[117] W.C. Oliver and G.M. Pharr, "An improved technique for determining hardness and elastic modulus using load and displacement sensing indentation experiments," J. Mater. Res., vol. 7, no. 6, pp. 1564-1583, 1992.

[118] J.L. Lábár, "Electron diffraction based analysis of phase fractions and texture in nanocrystalline thin films," Part I: principles, Microsc. Microanal., vol. 14, no. 4, pp. 287-295, 2008.

[119] J.L. Lábár, "Electron diffraction based analysis of phase fractions and texture in nanocrystalline thin films," Part II: implementation, Microsc. Microanal., vol. 15, no. 1, pp. 20-29, 2009.

[120] J.L. Lábár, M. Adamik, B.P. Barna, Zs. Czigány, Zs. Fogarassy, Z.E. Horváth, O. Geszti, F. Misják, J. Morgiel, G. Radnóczi, G. Sáfrán, L. Székely, and T. Szüts, "Electron diffraction based analysis of phase fractions and texture in nanocrystalline thin films," Part III: application examples, Microsc. Microanal., vol. 18, no. 3, pp. 406-420, 2012.

[121] J.L. Lábár, "Consistent indexing of a (set of) SAED pattern(s) with the ProcessDiffraction program," Ultramicroscopy, vol. 103, pp. 237-249, 2005.

[122] T.B. Massalski, Binary Alloy Phase Diagrams, 2nd ed.: ASM International, 1990, vol. 3.

[123] D.R. Lide, CRC Handbook of Chemistry and Physics.: CRC Press, 1993-1994.

[124] P. Baumli and G. Kaptay, "Wettability of carbon surfaces by pure molten alkali chlorides and their penetration into a porous graphite substrate," Mater. Sci. Eng. A , vol. 495, pp. 192-196, 2008. 
[125] L.Z. Mezey and J. Giber, "The surface free energies of solid chemical elements: calculation from internal free enthalpies of atomization," Jpn. J. Appl. Phys., vol. 21, pp. 1569-1571, 1982.

[126] G. Kaptay, "Modeling interfacial energies in metallic systems," Mater. Sci. Forum, vol. 473-474, pp. 1-10, 2005.

[127] G. Kaptay, "Nano-Calphad: extension of the Calphad method to systems with nano-phases and complexions," J. Mater. Sci., vol. 47, pp. 8320-8335, 2012.

[128] K.D. Esmeryan, C.E. Castano, A.H. Bressler, M. Abolghasemibizaki, C.P. Fergusson, A. Roberts, and R. Mohammadi, "Kinetically driven graphite-like to diamond-like carbon transformation in low temperature laminar diffusion flames," Diam.Relat. Mater., vol. 75, pp. 58-68, 2017.

[129] G.A. Viana and F.C. Marques, "Raman and thermal desorption spectroscopy analyses of amorphous graphite-like carbon films with incorporated xenon," Vacuum, vol. 112, pp. 17-24, 2015.

[130] A.C. Fernandes, L. Cunha, C. Moura, F. Vaz, P. Carvalho, E. Le Bourhis, Ph. Goudeau, J.P. Rivière, and N.M.G. Parreira, "The effect of bombarding conditions on the properties of multifunctional Ti-C-O thin films grown by magnetron sputtering," Surf. Coat. Technol., vol. 202, no. 4-7, pp. 946-951, 2007.

[131] H. Wu, T. Zhou, N. Zhang, and X. Zhu, "Assessments of the relation between the degree of order of the ultrafast laser deposited carbon film and the features of the Raman spectrum's D band," Surf. Coat. Technol., vol. 311, pp. 55-62, 2017.

[132] M. Amer, M.W. Barsoum, T. El-Raghy, I. Weiss, S. Leclair, and D. Liptak, "The Raman spectrum of Ti3SiC2," J. Appl. Phys., vol. 84, pp. 5817-5819, 1998.

[133] J.C. Sánchez-López, D. Martínez-Martínez, M.D. Abad, and A. Fernández, "Metal carbide/amorphous C-based nanocomposite coatings for tribological applications," Surf. Coat. Technol., vol. 204, no. 6-7, pp. 947-954, 2009.

[134] S. Louring, N.D. Madsen, M. Sillassen, A.N. Berthelsen, B.H. Christensen, K.P. Almtoft, H. Ronkainen, L.P. Nielsen, and J. Bøttiger, "Microstructural, mechanical and tribological analysis of nanocomposite Ti-C-N coatings deposited by industrial-scale DC magnetron sputtering," Surf. Coat. Technol., vol. 245, pp. 40-48, 2014.

[135] A.A. Voevodin, M.A. Capano, S.J.P. Laube, M.S. Donley, and J.S. Zabinski, "Design of a $\mathrm{Ti} / \mathrm{TiC} / \mathrm{DLC}$ functionally gradient coating based on studies of structural transitions in Ti-C thin films," Thin Solid Films, vol. 298, pp. 107-115, 1997.

[136] Q.N. Meng, M. Wen, F. Mao, N. Nedfors, U. Jansson, and W.T. Zheng, "Deposition and characteriaztion of reactive magnetron sputtered zirconium carbide films," Surf. Coat. Technol., vol. 232, pp. 876-883, 2013. 
[137] S. Sarian, "Diffusion of 44Ti in TiCx," J. Appl. Phys., vol. 40, pp. 3515-3522, 1969.

[138] E. Kusano, A. Sato, N. Kikuchi, H. Nanto, and A. Kinbara, "Preparation of TiC films by alternate deposition of Ti and C layers using a dual magnetron sputtering source," Surf. Coat. Technol., vol. 120-121, pp. 378-382, 1999.

[139] Zsolt Fogarassy, Nikolett Oláh, Ildikó Cora, Zsolt Endre Horváth, Tamás Csanádi, Attila Sulyok, and Katalin Balázsi, "The structural and mechanical characterization of TiC and TiC/Ti thin films grown by DC magnetron sputtering," J. Eur. Ceram. Soc., vol. 38, no. 7, pp. 2886-2892, 2018.

[140] N. Nedfors, O. Tengstrand, E. Lewin, A. Furlan, P. Eklund, L. Hultman, and U. Jansson, "Structural, mechanical and electrical-contact properties of nanocrystalline-NbC/amorphous- C coatings deposited by magnetron sputtering," Surf. Coat. Technol., vol. 206, pp. 354-359, 2011.

[141] C.E.Carlton and P.J.Ferreira, "What is behind the inverse Hall-Petch effect in nanocrystalline materials?," Acta Mater., vol. 55, no. 11, pp. 3749-3756, 2007.

[142] W. Gulbiński, S. Mathur, H. Shen, T. Suszko, A. Gilewicz, and B. Warcholiński, "Evaluation of phase, composition, microstructure and properties in TiC/a-C: $\mathrm{H}$ thin films deposited by magnetron sputtering," Appl. Surf. Sci., vol. 239, no. 3-4, pp. 302-306, 2005.

[143] T. Zehnder, P. Schwaller, F. Munnik, S. Mikhailov, and J. Patscheider, "Structure-performance relations in nanocomposite coatings," J. Appl. Phys., vol. 95, p. 4327, 2004.

[144] J. Musil, P. Novák, R. Čerstvý, and Z. Soukup, "Tribological and mechanical properties of nanocrystalline-TiC/a-C nanocomposite thin films," J. Vac. Sci. Technol. A, vol. 28, no. 2, pp. 244-249, 2010.

[145] A. Leyland and A. Matthews, "Review: plasma electrolysis for surface engineering," Wear, vol. 246, pp. 1-11, 2000.

[146] K. Sedláčkova, Zs. Czigány, T. Ujvári, I. Bertóti, R. Grasin, Gy.J. Kovács, and G. Radnóczi, "The effect of the carbon matrix on the mechanical properties of nanocomposite films containing nickel nanoparticles," Nanotechnology, vol. 18, p. 445604 (5pp), 2007.

[147] K. Sedláčková, R. Grasin, and G. Radnóczi, "Carbon-metal (Ni-Ti) nanocomposite film as protective coatings," in New Research on Nanocomposites, L.M. Krause, Ed. New York: Nova Pls., 2008, pp. 223-246.

[148] P. Souček, T. Schmidtová, V. Buršíková, P.Vašina, Y. T. Pei, J. Th. M. De Hosson, O. Caha, V. Peřina, R. Mikšová, and P. Malinský, "Tribological properties of nc-TiC/a-C:H coatings prepared by magnetron sputtering at low and high ion bombardment of the growing film," Surf. Coat. Technol., vol. 241, pp. 64-73, 2014.

[149] T.-H. Fang, S.-R. Jian, and D.-S. Chuu, "Nanomechanical properties of TiC, TiN and TiCN thin films using scanning probe microscopy and nanoindentation," Appl. Surf. Sci., vol. 228, pp. 365- 
372, 2004.

[150] D. Durgalakshmi, M. Chandran, G. Manivasagam, M.S. Ramachandra Rao, and R. Asokamani, "Studies on corrosion and wear behavior of submicrometric diamond coated Ti alloys," Tribol. Int., vol. 63, pp. 132-140, 2013.

[151] V. Swaminathan, H. Zeng, D. Lawrynowicz, Z. Zhang, and J.L. Gilbert, "Electrochemical investigations of chromium nanocarbide coated Ti-6Al-4V and Co-Cr-Mo alloy substrates," Electrochim. Acta, vol. 59, pp. 387-397, 2012.

[152] Y. Okazaki, T. Tateishi, and Y. Ito, "Corrosion resistance of implant alloys in Pseudo physiological solution and role of alloying elements in passive films," Mater. Trans. JIM, vol. 38, pp. 78-84, 1997.

[153] Margareth R. C. Marques, Raimar Loebenberg, and May Almukainzi, "Simulated Biological Fluids with Possible Application in Dissolution Testing," Dissolut. Technnol., vol. 18, no. 3, pp. 15-28, 2011.

[154] I. Mojzes and B. Kovács, Nanotechnology: a dedicated tool for the future, Mojzes Imre 1948, Kovács B., Mil-org Kft., and Nemzetközi Technológiai Intézet Budapest, Eds. Budapest: Budapest Neti, 1997.

[155] N. Arshi, J. Lu, C.G. Lee, J.H. Yoon, B.H. Koo, and F. Ahmed, "Thickness effect on properties of titanium film deposited by d. c. magnetron sputtering and electron beam evaporation techniques," Bull. Mater. Sci., vol. 36, pp. 807-812, 2013.

[156] D. Galvan, J.Th.M. De Hosson, C. Strondl Y.T. Pei, "Advanced TiC/a-C:H nanocomposite coatings deposited by magnetron sputtering," J. Eur. Ceram. Soc., vol. 26, pp. 565-570, 2006.

[157] D. Durgalakshmi, Maneesh Chandran, Geetha Manivasagam, M.S. Ramachandra Rao, and R. Asokamani, "Studies on corrosion and wear behavior of submicrometric diamond coated $\mathrm{Ti}$ alloys," Tribology International, vol. 63, pp. 132-140, 2013.

[158] S. Sarian, "Diffusion of 44Ti in TiCx," Journal of Applied Physics, vol. 3515, p. 40, 1969.

[159] A. Sato, N. Kikuchi, H. Nanto, A. Kinbara E. Kusano, "Preparation of TiC films by alternate deposition of $\mathrm{Ti}$ and $\mathrm{C}$ layers using a dual magnetron sputtering source," Surface and Coatings Technology, vol. 378-382, pp. 120-121, 1999.

[160] S. Sarian, "Diffusion of 44Ti in TiCx," J. Appl. Phys., vol. 40, pp. 3515 -3522, 1969. 